\title{
A catalogue of the Coleoptera of the Dutch Antilles
}

\author{
E.O. Colijn, K.K. Beentjes, R. Butôt, J.A. Miller, J.T. Smit, \\ A.J. de Winter and B. van der Hoorn
}

\begin{abstract}
This paper presents a first critical review of the beetle species (Insecta: Coleoptera) reported from the (former) Dutch Antilles as well as a history of beetle collecting and collectors on the islands. The introductory section provides a concise overview of the location, climate, geology and vegetation of the six islands. The catalogue is concluded with miscellaneous additions, corrections and annotations to the published records of the other islands of the northern Leeward Islands, and a comprehensive bibliography. (ZooBank registration: http://zoobank.org/ E2D76464-5AAE-4D75-9AC5-CA119E65D72A

Keywords:

E.O. Colijn*, J.T. Smit, European Invertebrate Survey, PO Box 9517, 2300 RA Leiden, The Netherlands.ed.colijn@naturalis.nl

K.K. Beentjes, R. Butôt, J.A. Miller, A.J. de Winter, B. van der Hoorn, Naturalis Biodiversity Center, PO Box 9517, 2300 RA Leiden, The Netherlands
\end{abstract}

\section{Introduction}

Little has changed since Wallace (1876) and almost a century later Geijskes \& Wagenaar Hummelinck (1951) wrote that only few have occupied themselves with the entomology of the Antilles. There is still a lot more to discover than is known at present about the islands' insect fauna. Ivie et al. (2008a) discuss the considerable challenges of conducting invertebrate inventories in the Antilles. Major problems are caused by the so-called taxonomic impediment, i.e. the gap in our taxonomic knowledge and the shortage of trained taxonomists for the Antillean region. As far as the Coleoptera are concerned the only relatively well-studied groups in the Antilles comprise the larger species of families such as the Carabidae, Scarabaeidae, Cerambycidae and Tenebrionidae. Bright (2019) recently published a comprehensive review of the Scolytinae which is now probably the best studied group in the Antilles. For most other groups modern revisions are lacking. The number of new provisional and genus-level records in this paper and others (e.g. Ivie et al. 2008b) illustrate that fact.
Peck $(2011,2016)$ recently published an overview of the beetles of the Lesser Antilles, including the northern Dutch Antilles. These papers are largely based on Blackwelder's (1944-1957) "Checklist of the coleopterous insects of Mexico, Central America, the West Indies, and South America". The present report offers a first critical review of all published records of the islands of the Dutch Antilles including information about their collectors and important collections. A number of new island records for the Dutch Antilles are also added, as well as corrections and additions to the checklists by Blackwelder (1944-1957) and Peck $(2011,2016)$ for the non-Dutch northern Leeward Islands.

\section{The islands of the (former) Dutch Antilles}

The (former) Dutch Antilles comprise the islands Aruba, Bonaire and Curaçao (also called the ABC islands) in the Leeward Antilles near the northeastern Venezuelan coast and Saba, St. Eustatius and St. Maarten in the northern Leeward Islands (Fig. 1). The two islands groups are approximately $900 \mathrm{~km}$ 


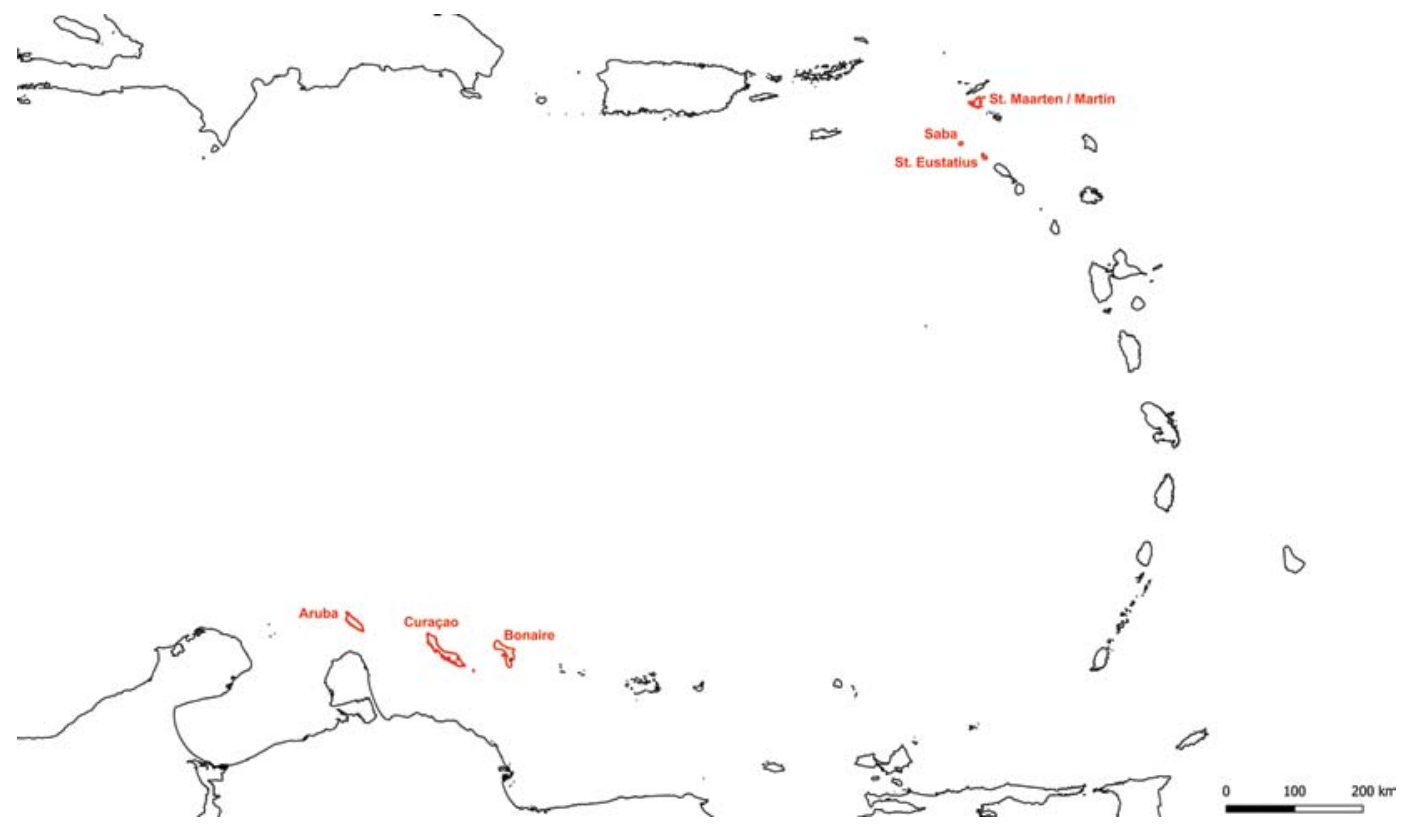

Figure 1. The (former) Dutch Antilles. Aruba, Bonaire, and Curaçao are part of the Leeward Antilles; Saba, St. Eustatius, and St. Martin are part of the Leeward Islands.

apart. St. Maarten is the southern part of the island St. Martin which is politically divided between the Netherlands and France (Fig. 2). Saba (Fig. 3), St. Eustatius (Fig. 4) and Bonaire (Fig. 5) are currently special municipalities of the Netherlands while Aruba (Fig. 6), Curaçao (Fig. 7) and St. Maarten are independent countries within the Kingdom of The Netherlands. The former French part of St. Martin is a separate overseas collectivity (collectivité d'outremer) of France. For convenience the term "former" is omitted in the rest of the text. Table 1 gives the basic properties and the number of Coleoptera species currently known for each island.

\section{Climate}

The islands of the Leeward Antilles are situated in the Southern Caribbean Dry Zone and have a semiarid tropical marine climate. The mean annual precipitation amounts to $550 \mathrm{~mm}$ with a large year-toyear variation: the standard deviation is larger than the mean. Rain falls irregularly, chiefly in short-lived showers that are often local. There is a "dry season" from February till September. The amount of precipitation during these months is about $200 \mathrm{~mm}$ in Curaçao and Bonaire, and less than $150 \mathrm{~mm}$ in Aruba. In the "rainy season", from October till January, the average precipitation lies between 300 and $350 \mathrm{~mm}$. Temperatures are rather constant over the year with a difference of only $3^{\circ} \mathrm{C}$ in average daily temperatures. The average annual temperature in the Leeward Antilles is approximately $28^{\circ} \mathrm{C}$. The Leeward Antilles are located on the southern boundary of the Atlantic hurricane region and, contrary to the Leeward Islands, the hurricane experience level for the islands is considered to be very small. Roughly once every 100 years considerable damage has been experienced by a hurricane passing over the islands (Martis et al. 2002, MDNA\&A 2009, 2010, CBS 2010, 2011).

Saba, St. Eustatius and St. Martin have a wetter tropical marine climate. With a mean annual precipitation of around $1000 \mathrm{~mm}$, the Leeward Islands receive about twice as much rain as the islands of the Leeward Antilles. However, all weather stations are located in lowland areas and rainfall on the mountains of Saba and St. Eustatius is certainly higher, possibly as much as twice the amount the lowlands receive. The wettest months, with an average monthly precipitation between 90 and $150 \mathrm{~mm}$, are $\mathrm{Au}-$ gust till December. There is a relatively dry period between January and April. As on the islands of the Leeward Antilles, temperatures are rather constant over the year with an average annual temperature of about $27^{\circ} \mathrm{C}$. The Leeward Islands are located within the Atlantic hurricane belt. The "official" Atlantic hurricane season runs from June through November but occasionally starts as early as May and may extend to December. Almost every year at least one 


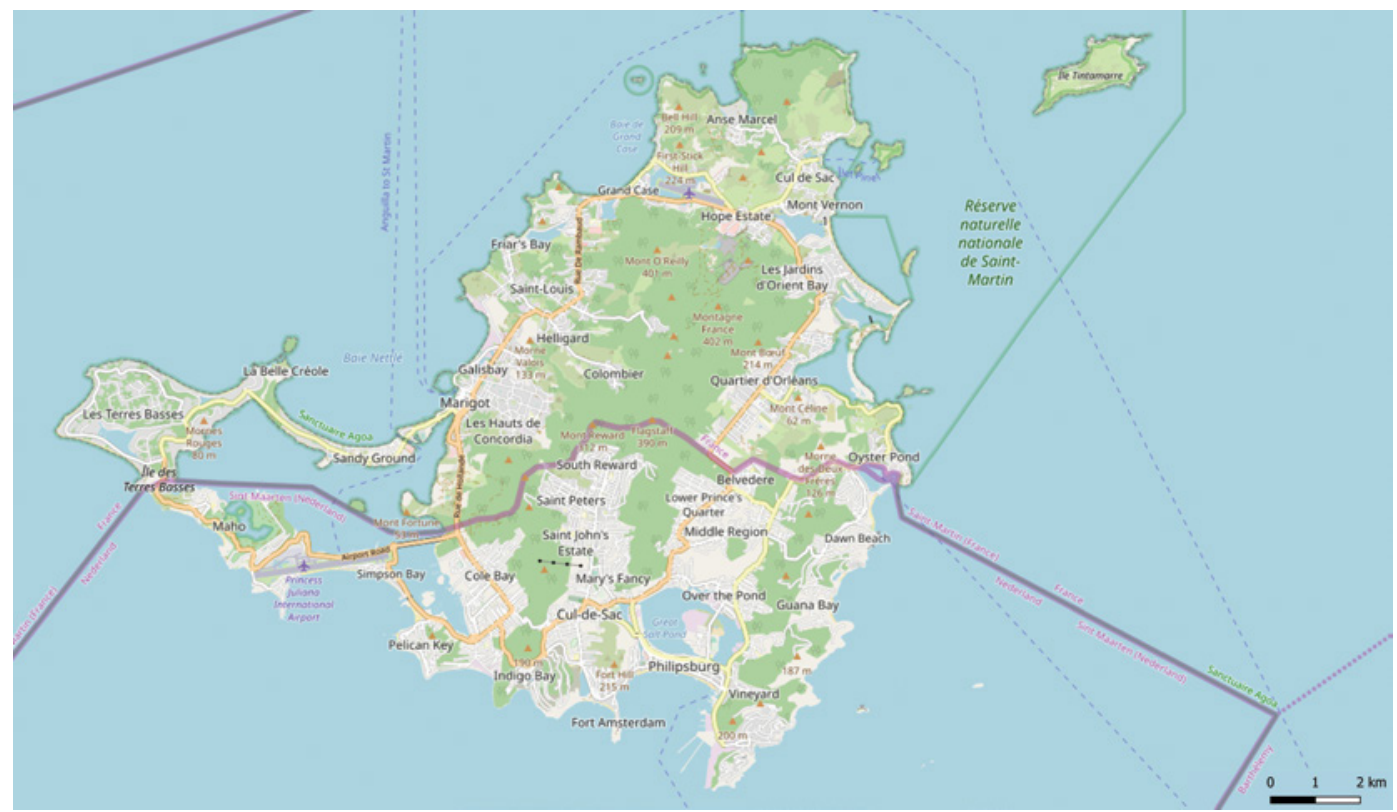

Figure 2. St. Maarten (southern part) / St. Martin (northern part). () OpenStreetMap (and) contributors, CC-BY-SA.

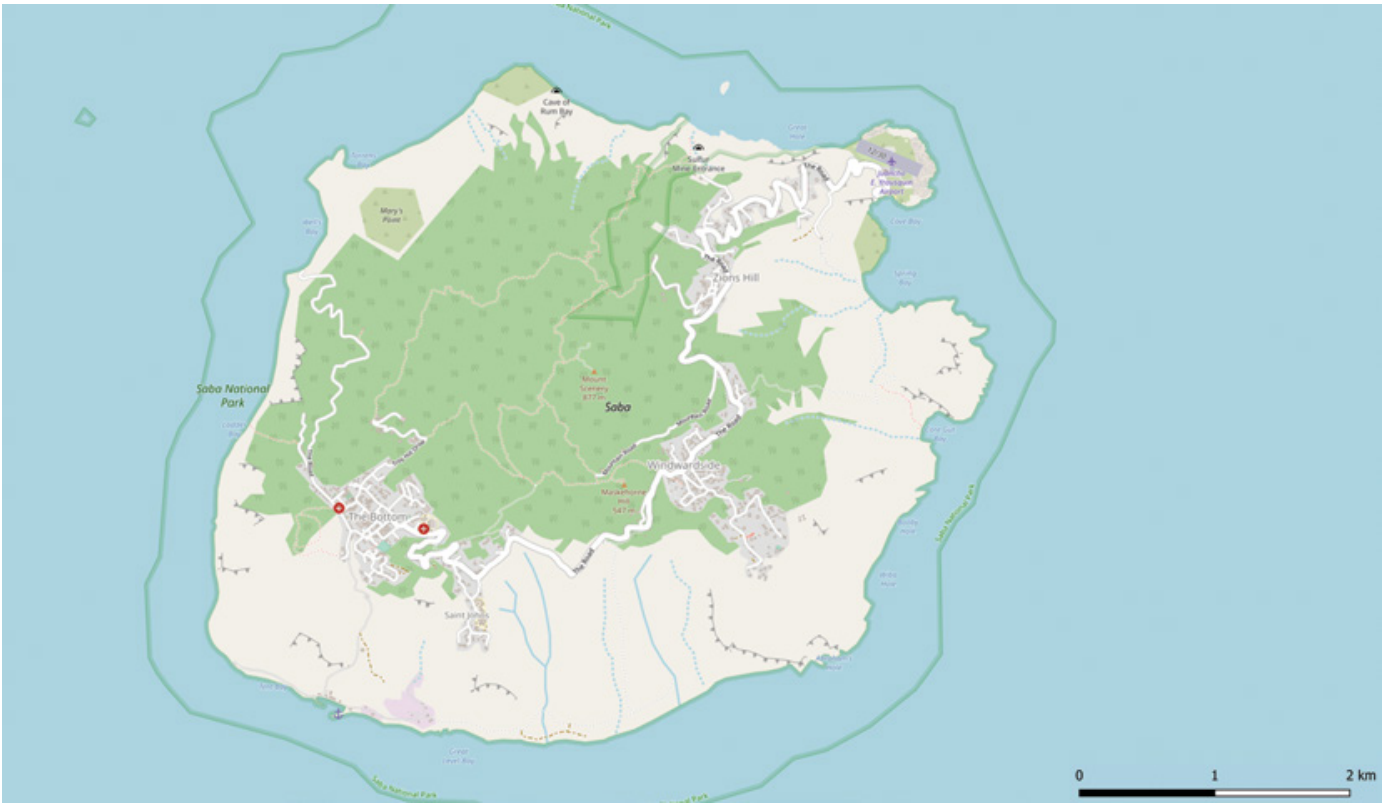

Figure 3. Saba. (C) OpenStreetMap (and) contributors, CC-BY-SA.

tropical cyclone comes within a range of 100 nautical miles and on average once every four to five years hurricane conditions are experienced on the islands. The most recent hurricane was the extremely pow- erful and catastrophic hurricane Irma which hit the islands in September 2017. It was the first category 5 hurricane on record to strike the Leeward Islands (MDNA\&A 2009, 2010, CBS 2010). 


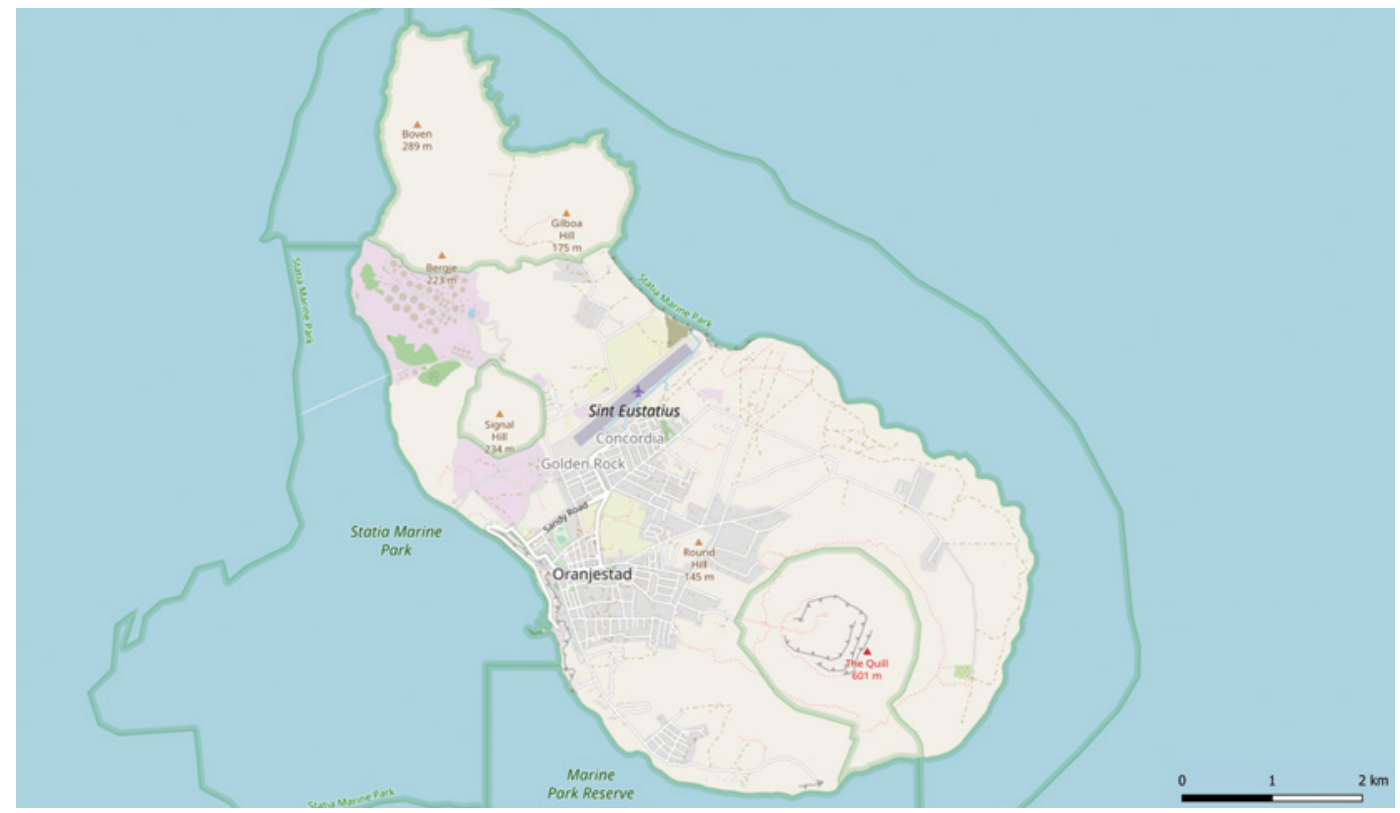

Figure 4. St. Eustatius. (C) OpenStreetMap (and) contributors, CC-BY-SA.

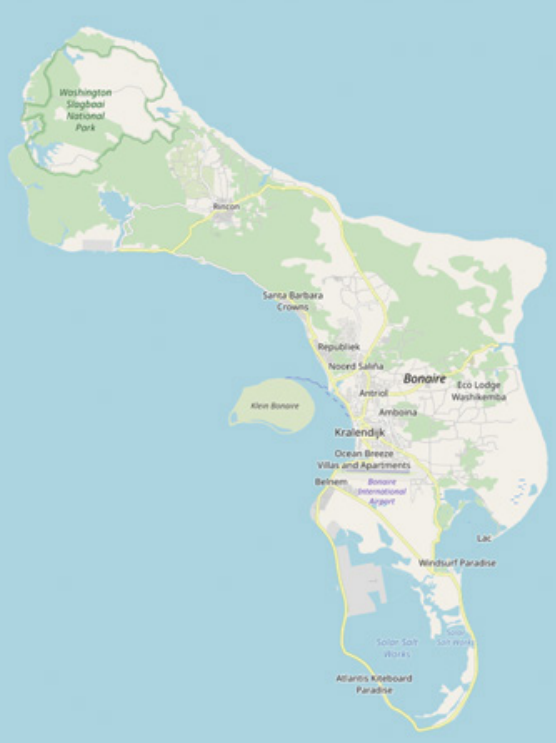

Figure 5. Bonaire. (C) OpenStreetMap (and) contributors, CC-BY-SA.

\section{Geology}

Aruba, Bonaire, and Curaçao lie along the crest of the so-called Leeward Antilles ridge. This ridge was formed by a series of complicated tectonic interactions between the Caribbean and South
American plates. Although considered continental islands, the Leeward Antilles ridge is actually located between the Caribbean and the South American plates with Bonaire and Curaçao both separated from the Venezuelan mainland, and each other, by 


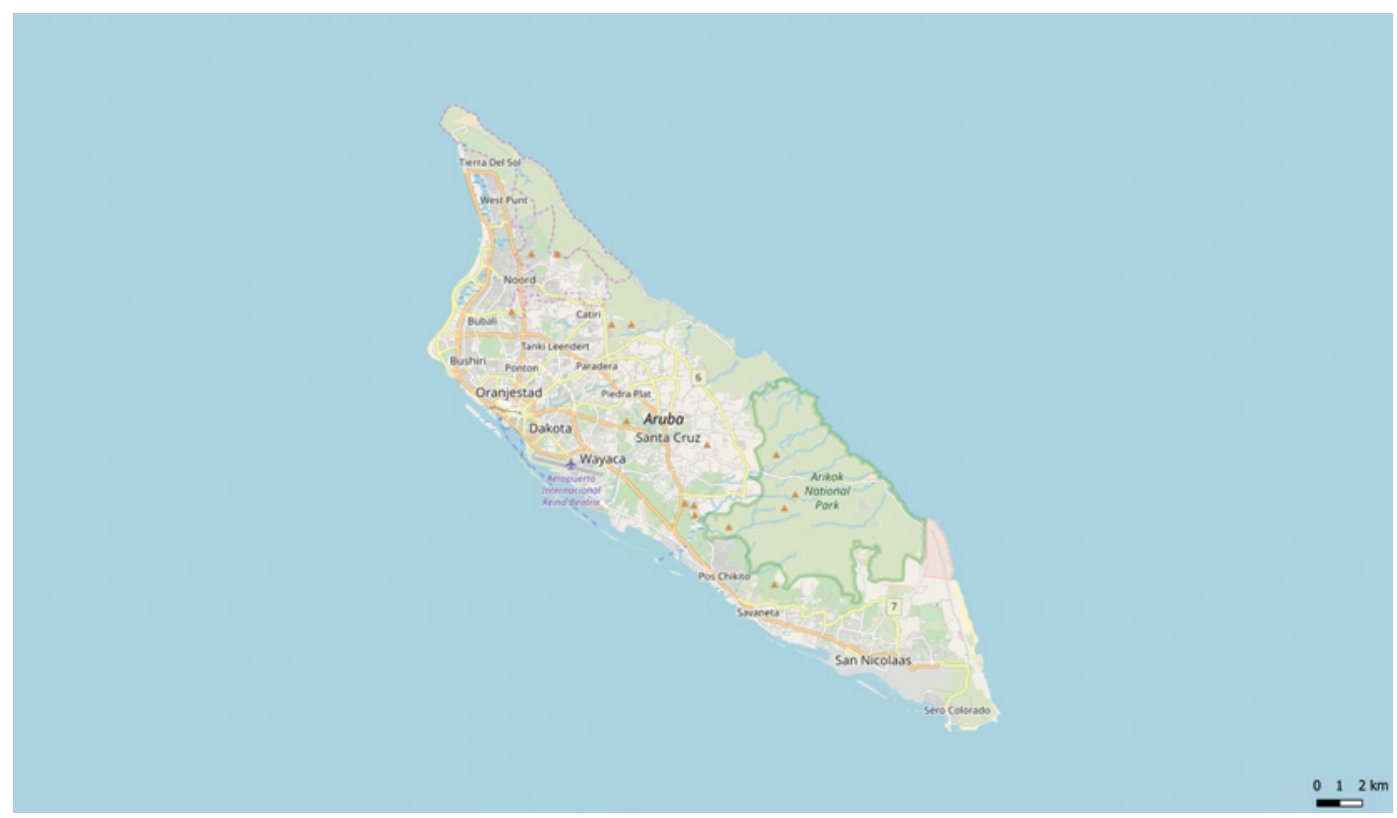

Figure 6. Aruba. (C) OpenStreetMap (and) contributors, CC-BY-SA.

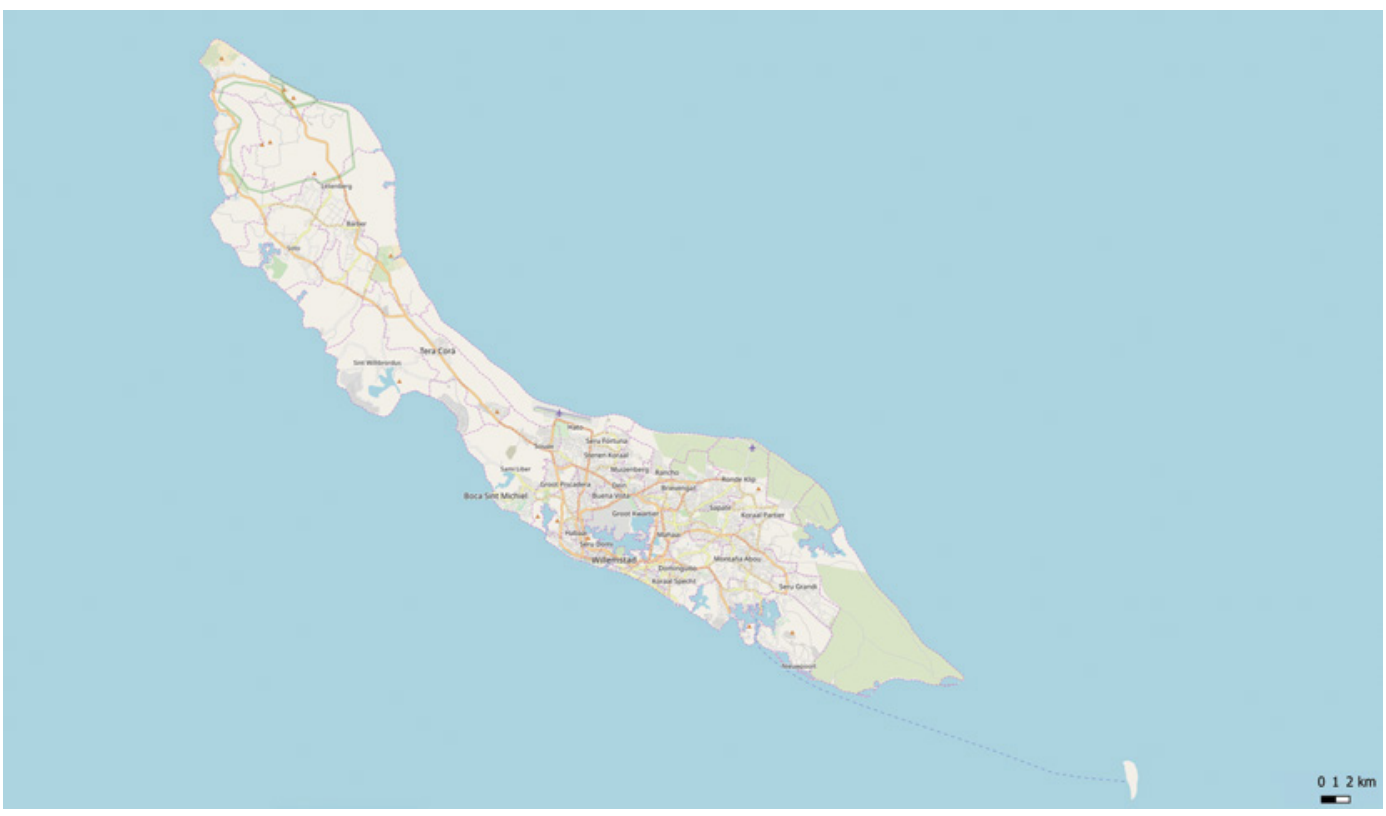

Figure 7. Curaçao. (C) OpenStreetMap (and) contributors, CC-BY-SA.

more than $1000 \mathrm{~m}$ deep seas. Aruba is the only island that is separated from the Venezuelan mainland by a relatively shallow sea with a maximum depth of approximately $180 \mathrm{~m}$. The islands of this group are relatively flat and consist of volcanic rocks partly

covered with marine sediments and limestone deposits (Wagenaar Hummelinck 1940, Hippolyte \& Mann 2011, Schmutz et al. 2017).

The Leeward Islands form a double arc of two geologically different groups of islands. St. Eustatius 


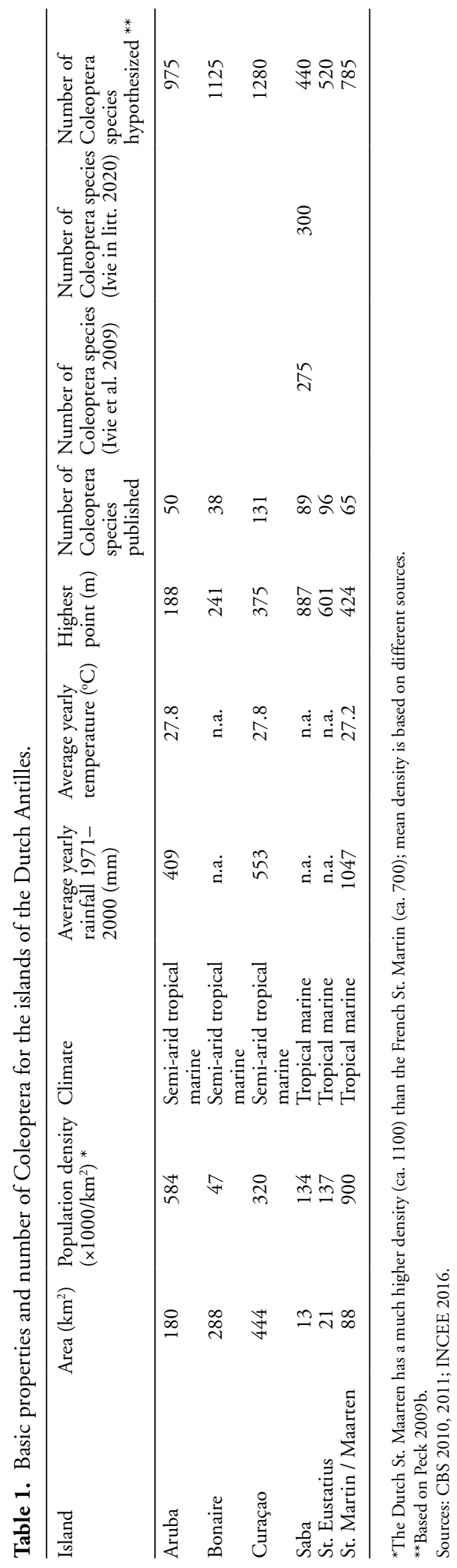

and Saba are part of the inner arc consisting of relatively young and active high volcanic islands. The former has two volcanic areas. The northern hills are the remnants of an extinct 500 million-year-old volcano. The southern Quill, is a dormant $601 \mathrm{~m}$ high stratovolcano that has not erupted for more than 1600-1700 years. On the southern side of the Quill lies a steep limestone cliff, an uplifted and tilted part of marine sediment of shallow-water origin that was displaced by submarine volcanic activity. During the Last Glacial Maximum St. Eustatius was connected to the neighbouring islands St. Kitts and Nevis. Mount Scenery $(887 \mathrm{~m})$ on Saba is also a dormant volcano although it is considered potentially active. It last erupted around the time the first European settlers arrived in 1640. Saba is very mountainous with steep slopes and ravines. Saba's cliffs drop off precipitously into the surrounding sea. The island is separated from the nearby Saba Bank by a 600$700 \mathrm{~m}$ deep trough and was probably never connected to any other land mass. St. Martin is located in the outer arc. The islands of this arc are lower and are eroded remnants of extinct volcanoes that have been covered with marine sediments and limestone deposits. During the Last Glacial Maximum St. Martin was connected to the neighbouring islands Anguilla and St. Barthélemy (Westerman 1957, Westermann \& Kiel 1961, Roobol \& Smith 2004, de Freitas et al. 2014, 2016).

\section{Vegetation}

Due to the combined effects of the arid climate, overgrazing by introduced goats and donkeys, and the felling of trees in the past the natural vegetation on the Leeward Antilles is dominated by secondary scrub communities. Grazing has also led to the dominance of thorny and grazing-resistant species. On the northeastern coasts the soil is fully exposed to the prevailing trade winds and the landscape has a rough and arid appearance with little vegetation. On the more sheltered coasts beach vegetation can be found, in some parts connected to mangrove swamps (Fig. 8). Inland the islands are sparsely vegetated with cactus scrub and thorny woodlands (Fig. 9) which are partly evergreen and partly deciduous (Wagenaar Hummelinck 1940, Stoffers 1956, Beers et al. 1997, de Freitas et al. 2005).

Saba, St. Eustatius and St. Martin are wetter and are less subject to trade winds. Although lying relatively close together, the islands all have their own characteristics. On Saba the lower arid hills up to approximately $200 \mathrm{~m}$ are covered with Croton thickets that are very poor in plant species. Above this area secondary woodlands can be found. These woodlands are partly derived from dry evergreen forest and partly from seasonal forest. The volcanic slopes 


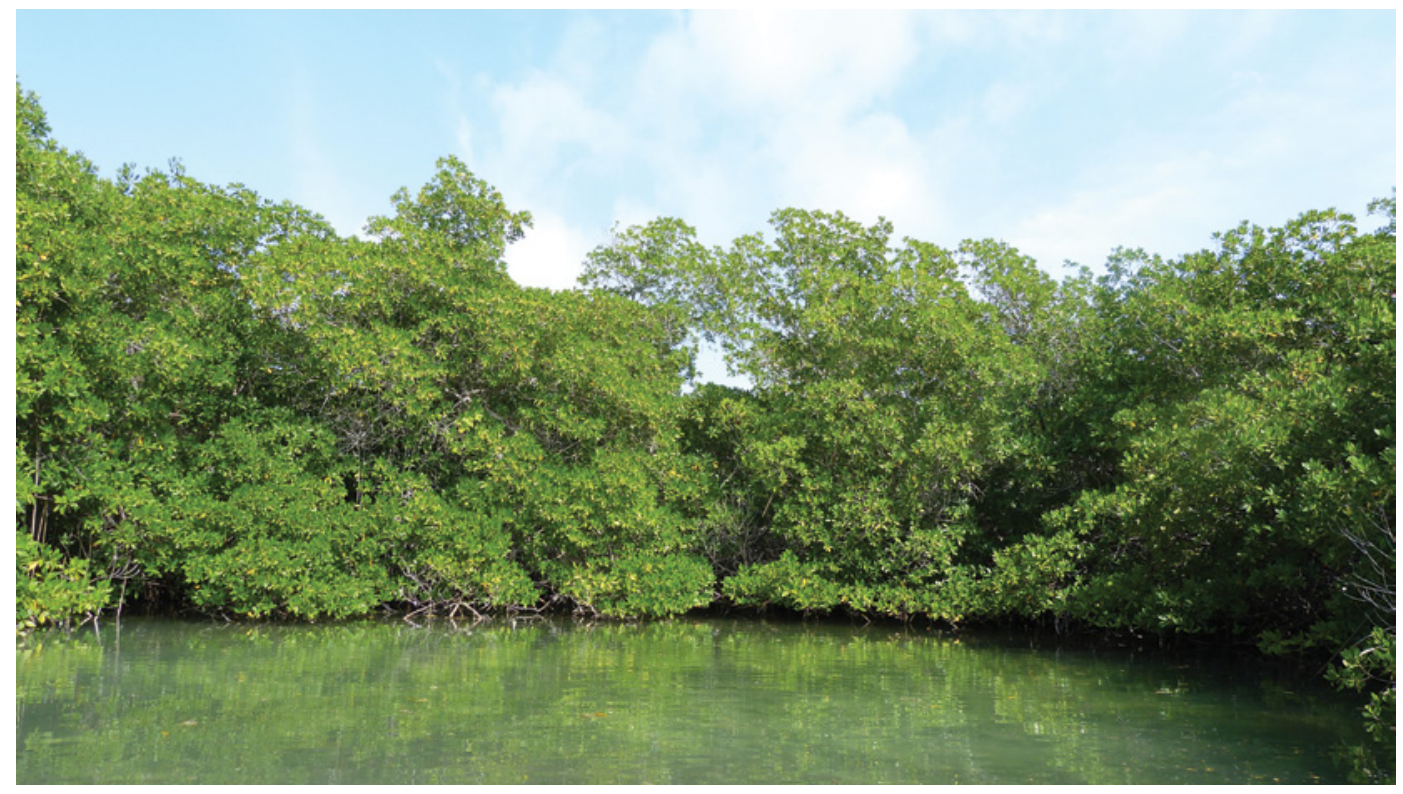

Figure 8. Mangrove forest in Lac Bay, Bonaire National Marine Park. Photo: Jaap Winkelman.

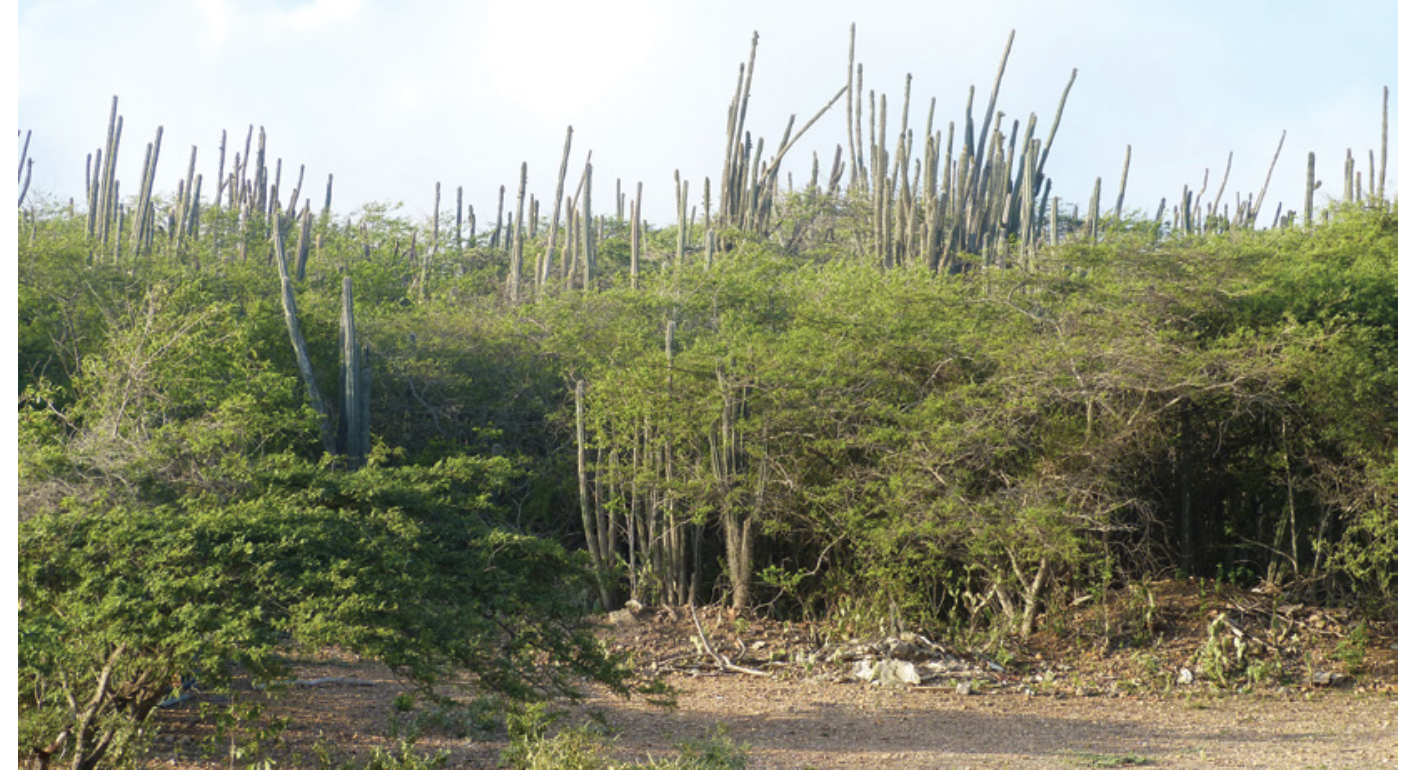

Figure 9. Cactus scrub and thorny woodlands, Rincon, Bonaire. Photo: Jaap Winkelman.

between 400 and $800 \mathrm{~m}$ were largely covered by rainforest and palm brake in former times. At present, these slopes host secondary rainforest vegetation which includes up to $4 \mathrm{~m}$ tall tree ferns. The top of Mt. Scenery supports montane cloud forest (Fig. 10).
The (semi-)natural vegetation on St. Eustatius is largely limited to the two volcanic areas and the coast. The central part of the island around Oranjestad consists of an open urbanised and (former) agricultural plain called the Cultuurvlakte. Along the coasts some small sandy beaches can be found 


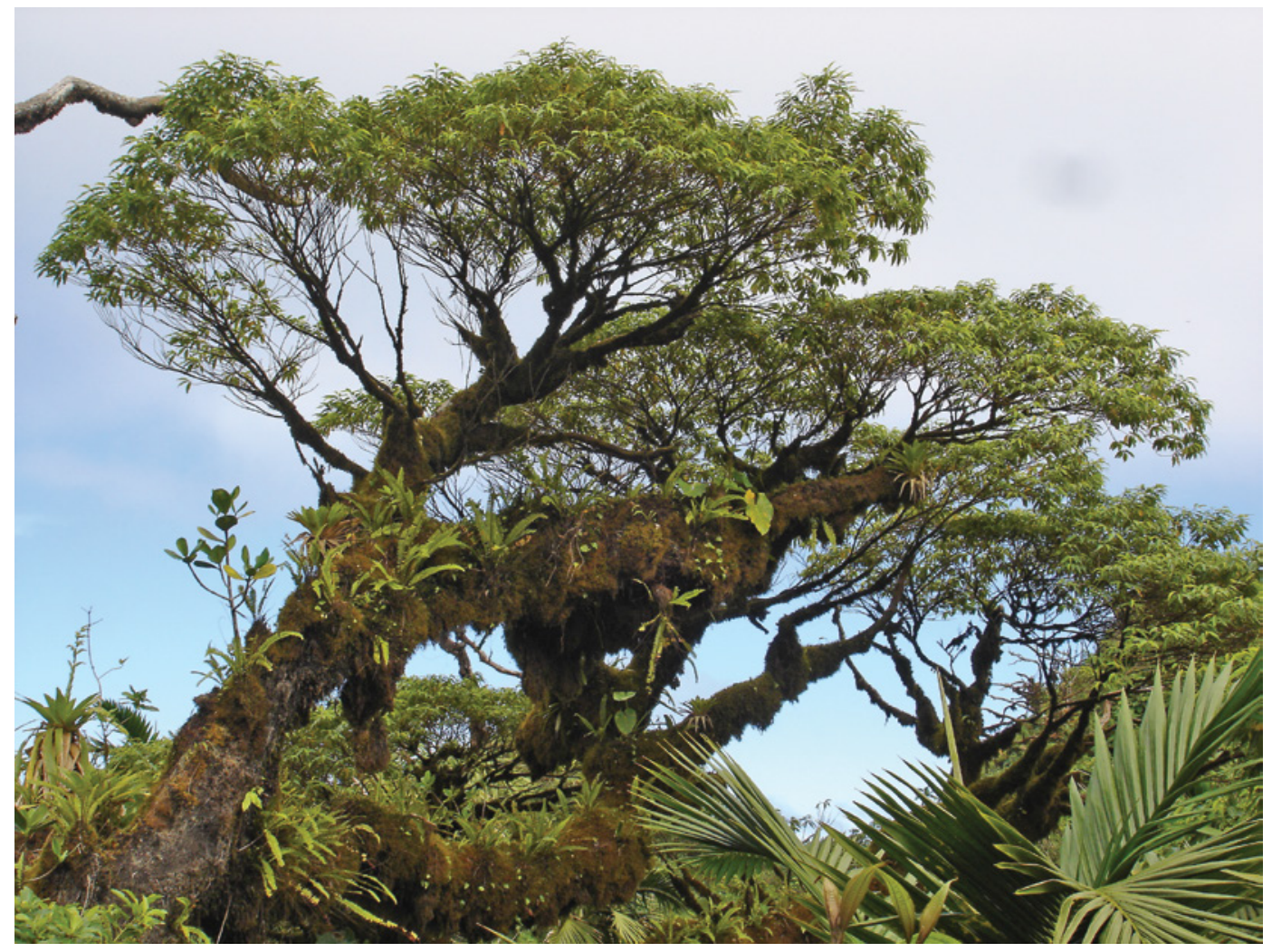

Figure 10. Cloud forest on Mt. Scenery. Photo: Michiel Boeken.

(Fig. 11). The northern hills are relatively dry. The vegetation consists of open, grassy shrubland and dry forest that is partly evergreen and partly deciduous. The vegetation on the Quill (Fig. 12) is very diverse and ranges from dry deciduous forest with relatively low trees on the lower slopes to humid evergreen forest with trees up to 40 metres high on the bottom of the crater (Fig. 13).

Due to intense agricultural development in the past St. Martin is now largely covered by secondary vegetation derived from seasonal or dry evergreen forests. There are just a few small areas located on the hills and peaks with original semi-evergreen seasonal forest. The secondary vegetation ranges from Croton thickets to thorny shrubland and woods. The coastal area hosts diverse landscapes with many bays and lagoons, steep rocky cliffs and sandy beaches. Along the coasts and the inland waterways small remnants of mangrove forests and other types of coastal vegetation can be found (Stoffers 1956, Rojer 1997a, 1997b, 1997c, de Freitas et al. 2014, 2016, van Andel et al. 2016).

\section{Methods}

\section{Bibliographic study}

To compile this catalogue the first author conducted an extensive study of the literature. Peck (2011, 2016) served as an excellent starting point for the Dutch northern Antilles. For the southern Dutch Antilles no such comprehensive review was available and the literature is very scattered. The Zoological Record (1864 to present), Google Scholar and WorldCat were used to search for literature records. Although riddled with errors and unreferenced deletions, the Global Biodiversity Information Facility (GBIF) holds useful information and was critically screened for additional species records. The citizenscience websites Observation.org and iNaturalist were also screened for additional species records with photos. All species references listed in papers pertaining to (former) Dutch Antillean island records were checked, going back to the first published island records as well as the original descriptions of each species. 


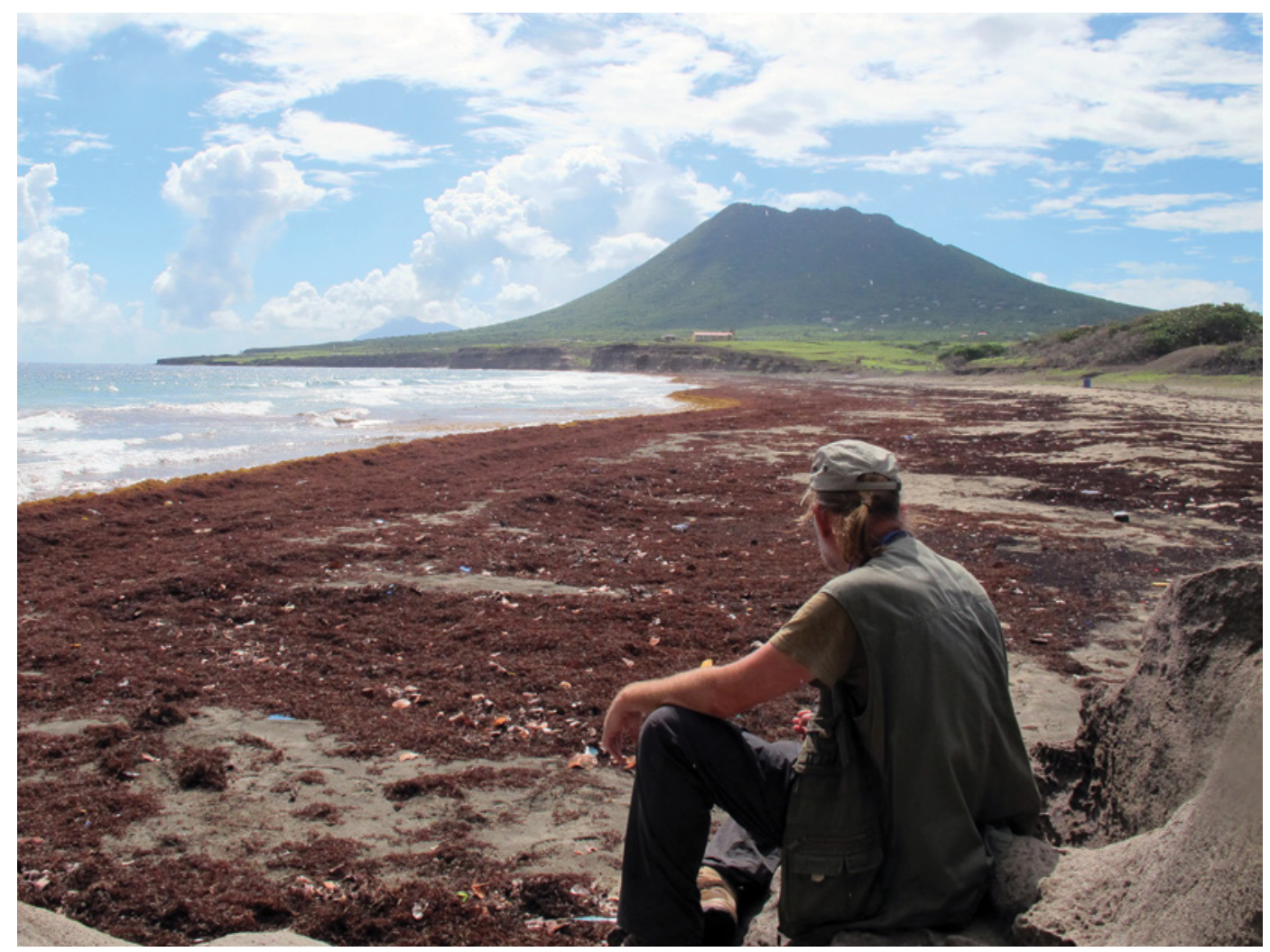

Figure 11. Small sandy beach with the Quill in the background, Zeelandia, St. Eustatius. Photo: Roland Butôt.

\section{Data included}

The first part of this catalogue provides an overview of collectors that have been active in the Dutch Antilles. In the following systematic catalogue all Dutch Antillean Coleoptera records based on preserved museum specimens (vouchers) are listed (see also Table 2). If these are unclear or records are solely based on photos the records are considered provisional, the island name is placed within square brackets and an annotation is added. We did not include species recorded without vouchers for which voucher-based records have already been published. Clearly erroneous or unlikely records in GBIF were discarded without comment. All records in Touroult's GBIF datasets (Touroult 2019a, b) are listed as "human observation" but about $90 \%$ of his data are based on vouchers (Touroult in litt. 2020). As such, all his GBIF records are included here.

For each entry the species name, author, island name, reference and if available exact location and collector of vouchers (or observer in case of records from the citizen-science websites iNaturalis and
Observation.org) are listed. In case of a formal species description a comma is included in the citation. All other citations are listed without this comma and with a colon between the species name and the author. No division has been made between the Dutch and French parts of St. Martin and all records of this island are included. Erroneous or questionable records for the Dutch Antilles are treated in a separate chapter.

While working on the catalogue a number of errors and omissions were discovered in Peck's (2011, 2016) checklists including records for the other islands of the northern Leeward Islands (Anguilla, Antigua, Barbuda, Nevis, St. Barthélemy and St. Kitts and here also including Montserrat). Various records from recent publications and citizen-science records have also been added to his checklists. As far as species present on the Dutch islands are concerned, corrections and (provisional) additions to Peck (2011, 2016) are included in the main text of the systematic catalogue. Annotations on species not present on the Dutch islands are listed in a separate final chapter. 


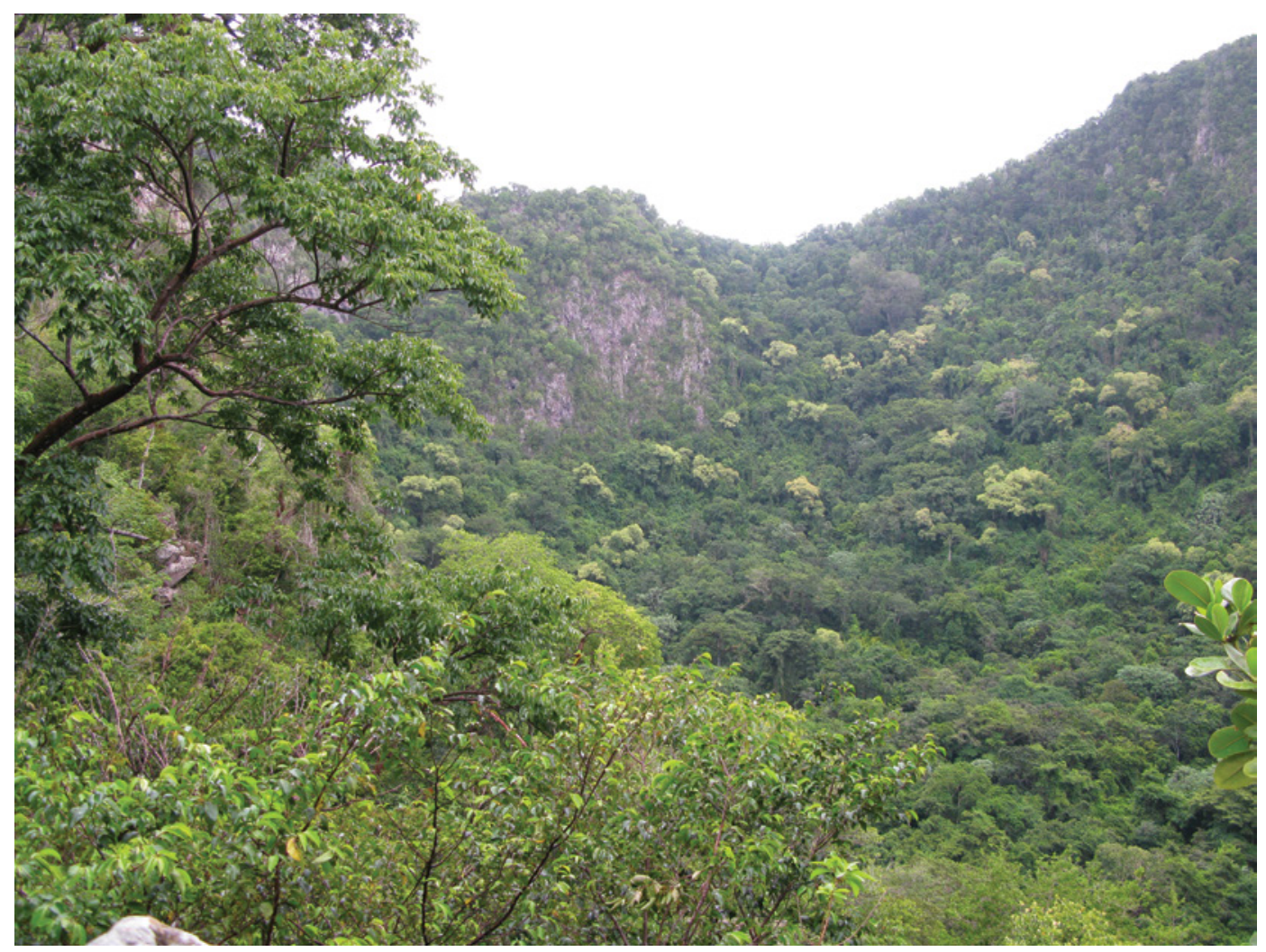

Figure 12. The Quill, view from the crater rim inside the crater. Photo: Marijke Kanters

\section{Classification and taxonomy}

For convenience the (sub)familial level classification of the most recent review of the beetles of the Lesser Antilles (Peck 2016) is followed. This is that of Arnett \& Thomas (2001) and Arnett et al. (2002), modified from Lawrence \& Newton (1995). The taxonomic ranks tribe, subtribe, subgenus and subspecies are not used. Species names are arranged alphabetically.

\section{Field work}

The St. Eustatius Scientific Terrestrial Expedition (Fig. 13) took place from 2 to 18 October 2015 and was organised by Naturalis Biodiversity Center in cooperation with the St. Eustatius National Parks Foundation (STENAPA). The expedition formed the main reason to start compiling this catalogue.

A team of researchers of Naturalis, the European Invertebrate Survey The Netherlands (EIS), the Dutch Mammal Society (VZZ), the Reptile, Amphibian \& Fish Conservation Netherlands (RAVON) and students led by the last author conducted a rapid inventory of the biodiversity of the island. All authors collected Coleoptera during the expedition.
Unless stated otherwise in the text, these were identified by the first author and are now partly housed in the author's private collection and partly in the collection of Naturalis Biodiversity Center. R. Butôt was responsible for laboratory logistics.

The primary aim of the expedition was to investigate which taxonomic groups could stand as surrogates for others in conservation assessments. To this end, 11 plots measuring $25 \times 25 \mathrm{~m}$ were set out in which plants, vertebrates, gastropods and selected arthropods were sampled using several techniques including beating, sweeping, sieving, yellow pan, pitfall, Malaise and Winkler traps (Fig. 14). The results of this systematic research study will be published elsewhere (see also Miller et al. 2017, 2019).

The expedition further aimed at collecting baseline data on the biodiversity of St. Eustatius as a whole. In some of the plots light traps were set up. Outside the plots specific habitats such as dung, carrion (Fig. 15), dead wood, washed-up seaweed, small pools and water reservoirs were sampled (Figs 16, 17). A separate Malaise trap was set up on the slopes of the Quill. The results of this more opportunistic sampling approach are included in this paper. 


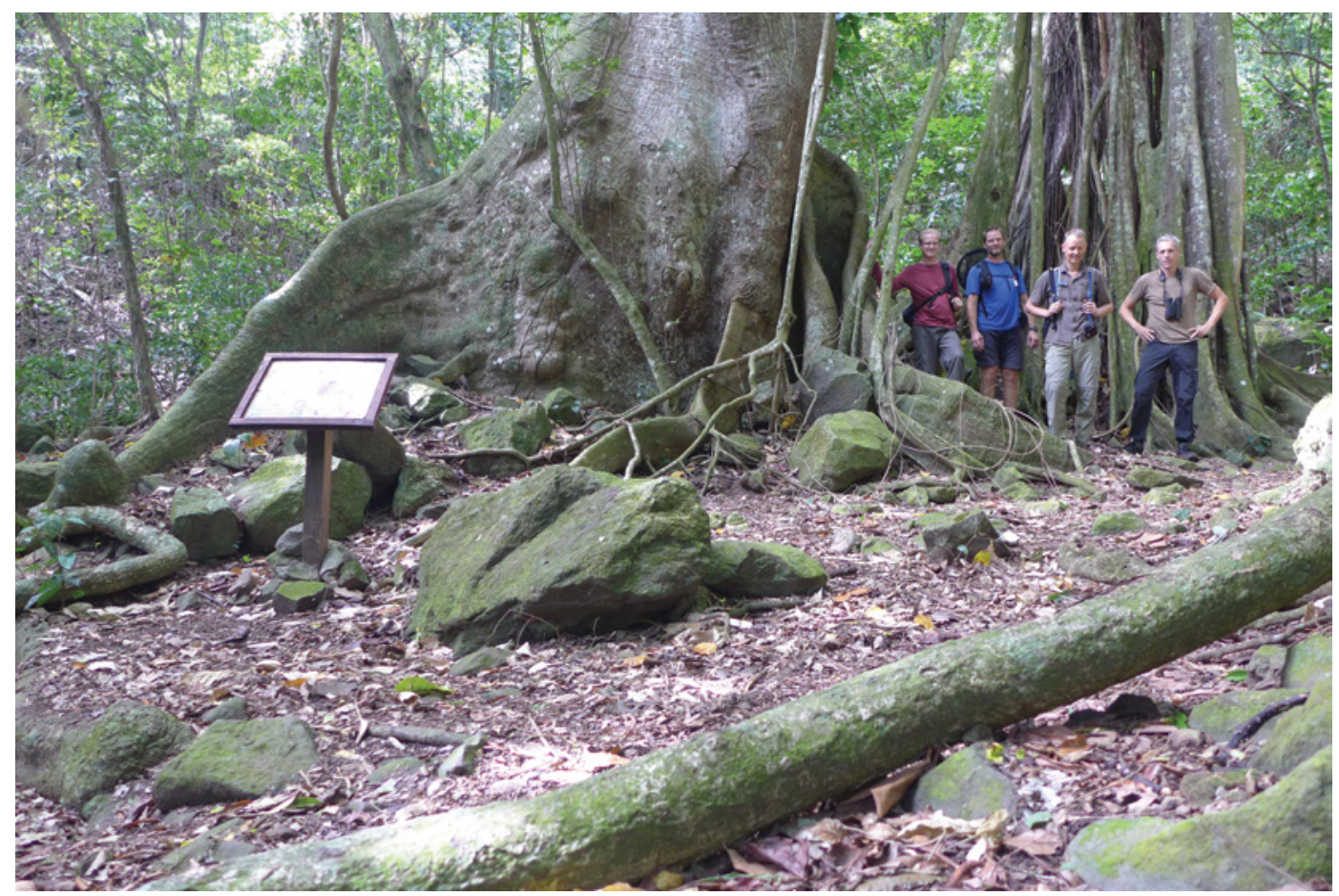

Figure 13. Part of the team next to buttress-rooted trees at the bottom of the Quill. From left to right: Kevin Beentjes, Roland Butôt, Jeroen van der Brugge and Berry van der Hoorn. Photo: Berry van der Hoorn.

Table 2. Coleoptera of the Dutch Antilles. "1" indicates a species record based on vouchers, "0" a record that is not based on vouchers.

\begin{tabular}{|c|c|c|c|c|c|c|c|c|}
\hline Family & Subfamily & Species & Aruba & Curaçao & Bonaire & St. Martin & Saba & St. Eustatius \\
\hline Carabidae & Carabinae & Calosoma alternans & 0 & 1 & & 1 & & \\
\hline Carabidae & Cicindelinae & Brasiella argentata & & 1 & & & & \\
\hline Carabidae & Cicindelinae & Cicindela trifasciata & & & & 1 & & \\
\hline Carabidae & Cicindelinae & Cylindera suturalis & & 1 & & 1 & & \\
\hline Carabidae & Cicindelinae & Habroscelimorpha auraria & 1 & 1 & 1 & & & \\
\hline Carabidae & Cicindelinae & Tetracha gracilis & 1 & 1 & & & & \\
\hline Carabidae & Cicindelinae & Tetracha sobrina & 1 & 1 & 1 & 1 & & \\
\hline Carabidae & Scaritinae & Paraclivina fasciata & & & & & 1 & \\
\hline Carabidae & Scaritinae & Paraclivina tristis & & 1 & 1 & & & \\
\hline Carabidae & Harpalinae & Apenes variegata & & & & 1 & & 1 \\
\hline Carabidae & Harpalinae & Athrostictus paganus & & & & 1 & & 1 \\
\hline Carabidae & Harpalinae & Eucheila boyeri & 1 & & & & & \\
\hline Carabidae & Harpalinae & Galerita americana & & & & 1 & & \\
\hline Carabidae & Harpalinae & Neoaulacoryssus cupripennis & 1 & & & & & \\
\hline Carabidae & Harpalinae & Pentagonica flavipes & & & & & 1 & 1 \\
\hline Carabidae & Harpalinae & Selenophorus alternans & & & & & 1 & \\
\hline Carabidae & Harpalinae & Selenophorus discopunctatus & & & & 1 & 1 & 1 \\
\hline Carabidae & Harpalinae & Selenophorus flavilabris & & & & 1 & & \\
\hline Carabidae & Harpalinae & Selenophorus integer & & & & 1 & 1 & 1 \\
\hline Carabidae & Harpalinae & Selenophorus parumpunctatus & & & & 1 & 1 & 1 \\
\hline Carabidae & Harpalinae & Selenophorus propinquus & & & & 1 & 1 & 1 \\
\hline Carabidae & Harpalinae & Selenophorus subquadratus & & & & & 1 & \\
\hline Carabidae & Harpalinae & Selenophorus woodruffi & 1 & 1 & & & & \\
\hline Carabidae & Harpalinae & Stenomorphus angustatus & & 1 & & & & \\
\hline Gyrinidae & Gyrininae & Dineutus americanus & & 1 & & & & \\
\hline Gyrinidae & Gyrininae & Gyrinus ovatus & & 1 & & & & \\
\hline
\end{tabular}


Table 2. Coleoptera of the Dutch Antilles. " 1 " indicates a species record based on vouchers, " 0 " a record that is not based on vouchers. (cont.)

\begin{tabular}{|c|c|c|c|c|c|c|c|c|}
\hline Family & Subfamily & Species & Aruba & Curaçao & Bonaire & St. Martin & Saba & St. Eustatius \\
\hline Haliplidae & & Haliplus gravidus & & 1 & 1 & 1 & & \\
\hline Noteridae & & Hydrocanthus debilis & 1 & & & & & \\
\hline Noteridae & & Suphis cimicoides & 1 & & & & & \\
\hline Noteridae & & Suphisellus nigrinus & 1 & & & & & \\
\hline Dytiscidae & Copelatinae & Copelatus caelatipennis & 1 & & & & & \\
\hline Dytiscidae & Hydroporinae & Celina species & 1 & & & & 1 & \\
\hline Dytiscidae & Hydroporinae & Pachydrus globosus & 1 & & & & & \\
\hline Dytiscidae & Dytiscinae & Megadytes laevigatus & 1 & & & & & \\
\hline Dytiscidae & Dytiscinae & Thermonectus circumscriptus & & & & & & 1 \\
\hline Hydrophilidae & Hydrophilinae & Berosus species & 1 & & & & & \\
\hline Hydrophilidae & Hydrophilinae & Enochrus sharpi & 1 & & & & & \\
\hline Hydrophilidae & Hydrophilinae & Hydrophilus insularis & 1 & & 1 & & & 1 \\
\hline Hydrophilidae & Hydrophilinae & Laccobius species & & & & & 1 & \\
\hline Hydrophilidae & Hydrophilinae & Tropisternus collaris & 1 & & & & & \\
\hline Hydrophilidae & Hydrophilinae & Tropisternus lateralis & 1 & & & 0 & 1 & 1 \\
\hline Hydrophilidae & Sphaeridiinae & Cercyon nigriceps & & & & & 1 & \\
\hline Hydrophilidae & Sphaeridiinae & Oosternum sharpi & & & & & 1 & \\
\hline Hydrophilidae & Sphaeridiinae & Phaenonotum exstriatum & 1 & & & & & \\
\hline Histeridae & Abraeinae & Halacritus blackwelderi & & & & & & 1 \\
\hline Histeridae & Abraeinae & Aeletes species & & & & & 1 & \\
\hline Histeridae & Histerinae & Hister servus & & & & & 1 & \\
\hline Histeridae & Saprininae & Hypocaccus brasiliensis & & & & & & 1 \\
\hline Histeridae & Saprininae & Xerosaprinus testudo & & 1 & & 1 & & 1 \\
\hline Histeridae & Saprininae & Xerosaprinus viator & & 1 & & & & \\
\hline Leiodidae & Leiodinae & Zeadolopus antiguensis & & & & & 1 & \\
\hline Scydmaenidae & Scydmaeninae & Euconnus satishanandi & & 1 & & & & \\
\hline Scymaenidae & Scydmaeninae & Euconnus species & & & & & 1 & \\
\hline Staphylinidae & Pselaphinae & Eupsenius politus & & & & & & 1 \\
\hline Staphylinidae & Aleocharinae & Diestota sperata & & & & 1 & & \\
\hline Staphylinidae & Osoriinae & Molosoma species & & & & & & 1 \\
\hline Staphylinidae & Megalopsidiinae & Megalopinus punctatus & & 1 & & & & \\
\hline Staphylinidae & Paederinae & Sciocharis exilis & & & & & & 1 \\
\hline Staphylinidae & Staphylininae & Cafius bistriatus & & & & & & 1 \\
\hline Trogidae & & Omorgus suberosus & & & 1 & 1 & 1 & 1 \\
\hline Hybosoridae & Hybosorinae & Hybosorus illigeri & & & & & & 1 \\
\hline Scarabaeidae & Aphodiinae & Ataenius complicatus & & 1 & & & & \\
\hline Scarabaeidae & Aphodiinae & Ataenius gracilis & & & & & 1 & \\
\hline Scarabaeidae & Aphodiinae & Ataenius scutellaris & & & & 1 & 1 & \\
\hline Scarabaeidae & Aphodiinae & Ataenius cf. strigicaudus & & & & & & 1 \\
\hline Scarabaeidae & Aphodiinae & Labarrus lividus & & & & & 1 & \\
\hline Scarabaeidae & Aphodiinae & Nialaphodius nigrita & & & & & 1 & 1 \\
\hline Scarabaeidae & Aphodiinae & Psammodius sp. aff. viti & & & & & & 1 \\
\hline Scarabaeidae & Cetoniinae & Cotinis species & 1 & & & & & \\
\hline Scarabaeidae & Scarabaeinae & Digitonthophagus gazella & & & & 0 & & 1 \\
\hline Scarabaeidae & Scarabaeinae & Pseudocanthon species & & 0 & & & & \\
\hline Scarabaeidae & Melolonthinae & Phyllophaga sanbarthensis & & & & 1 & & \\
\hline Scarabaeidae & Melolonthinae & Phyllophaga stehlei & & & & 1 & & \\
\hline Scarabaeidae & Dynastinae & Chalepides barbatus & & & & 1 & & \\
\hline Scarabaeidae & Dynastinae & Cyclocephala amazona & & & & 1 & & \\
\hline Scarabaeidae & Dynastinae & Cyclocephala immaculata & & & & 1 & & \\
\hline Scarabaeidae & Dynastinae & Cyclocephala mafaffa & & & & & 1 & \\
\hline Scarabaeidae & Dynastinae & Phileurus valgus & & 0 & & 1 & 1 & 1 \\
\hline Scarabaeidae & Dynastinae & Strategus aloeus & & 1 & & & & \\
\hline Scarabaeidae & Dynastinae & Tomarus cuniculus & & & & 1 & 1 & 1 \\
\hline Scarabaeidae & Dynastinae & Tomarus fossor & & 1 & 1 & & & \\
\hline Buprestidae & Buprestinae & Chrysobothris sabae & & & & & 1 & \\
\hline Buprestidae & Buprestinae & Conognatha olivacea & & 1 & & & & \\
\hline Chelonariidae & & Chelonarium pilosellum & & & & & 1 & \\
\hline Elateridae & Elaterinae & Dicrepidius ignotus & & & & & 1 & \\
\hline Elateridae & Elaterinae & Physorhinus distigma & & & & & & 1 \\
\hline Elateridae & Cardiophorinae & Esthesopus poedicus & & & & 1 & & 1 \\
\hline Elateridae & Agyrpninae & Aeolus sp. aff. circumscriptus & & & & 1 & & \\
\hline Elateridae & Agyrpninae & Conoderus bifoveatus & & & & 1 & 1 & 1 \\
\hline Elateridae & Agyrpninae & Conoderus castaneus & & & & 1 & & \\
\hline Elateridae & Agyrpninae & Heteroderes amplicollis & & & & 1 & & \\
\hline Elateridae & Agyrpninae & Lacon subcostatus & & Dowr & nloaded & $\begin{array}{ll} & 0 \\
\text { from } & \text { Bril }\end{array}$ & com04 & $/ 26 / 2023$ \\
\hline
\end{tabular}


Table 2. Coleoptera of the Dutch Antilles. "1" indicates a species record based on vouchers, "0" a record that is not based on vouchers. (cont.)

\begin{tabular}{|c|c|c|c|c|c|c|c|c|}
\hline Family & Subfamily & Species & Aruba & Curaçao & Bonaire & St. Martin & Saba & St. Eustatius \\
\hline Lampyridae & Lampyrinae & Aspisoma ignitum & & & & 1 & & 1 \\
\hline Dermestidae & Dermestinae & Dermestes maculatus & & & & & & 1 \\
\hline Dermestidae & Attageninae & Attagenus fasciatus & & & 1 & & & \\
\hline Dermestidae & Megatominae & Trogoderma serraticorne & 1 & & & & & \\
\hline Bostrichidae & Polycaoninae & Melalgus gonagrus & & & & & 1 & \\
\hline Bostrichidae & Bostrichinae & Amphicerus cornutus & & 0 & 1 & 1 & & 1 \\
\hline Bostrichidae & Bostrichinae & Xylomeira tridens & & & & 0 & & 1 \\
\hline Anobiidae & Ptininae & Bellesus cristithorax & 1 & 1 & 1 & & & \\
\hline Anobiidae & Ptininae & Pitnus longicornis & & 1 & 1 & & & \\
\hline Anobiidae & Ptininae & Pitnus robustus & 1 & 1 & & & & \\
\hline Anobiidae & Dorcatominae & Cryptorama cf. antillensis & & & & & & 1 \\
\hline Anobiidae & Dorcatominae & Petalium cf. pici & & & & & & 1 \\
\hline Anobiidae & Dorcatominae & Petalium species & & & & & & 1 \\
\hline Anobiidae & Dorcatominae & Tricorynus cf. neltumae & & & & & & 1 \\
\hline Trogossitidae & Lophocaterinae & Lophocateres pusillus & & 0 & & & & \\
\hline Cleridae & Enopliinae & Neorthopleura turnbowi & & 1 & & & & \\
\hline Cleridae & Korynetinae & Necrobia rufipes & & & & 0 & & 1 \\
\hline Melyridae & Melyrinae & Astylus species & & 0 & & & & \\
\hline Nitidulidae & Cillaeinae & Conotelus conicus & & & & 1 & & \\
\hline Nitidulidae & Carpophilinae & Carpophilus species & & 1 & & & & \\
\hline Nitidulidae & Carpophilinae & Epuraea luteola & & & & & 1 & \\
\hline Nitidulidae & Nitidulinae & Lobiopa insularis & & & & 0 & 1 & \\
\hline Nitidulidae & Nitidulinae & Stelidota strigosa & & & & & & 1 \\
\hline Nitidulidae & Cybocephalinae & Cybocephalus caribaeus & & 1 & & & & \\
\hline Monotomidae & Monotominae & Bactridium heydeni & & 1 & & & & \\
\hline Monotomidae & Monotominae & Monotoma longicollis & & 1 & & & & \\
\hline Monotomidae & Monotominae & Monotoma spinicollis & & & & & 1 & \\
\hline Silvanidae & Silvaninae & Monanus concinnulus & & & & & & 1 \\
\hline Passandridae & & Taphroscelidia atratula & & 1 & & & & \\
\hline Phalacridae & & Apallodes species & & & & & 1 & \\
\hline Phalacridae & & Litostilbus tristriatus / testaceus & & & & & 1 & 1 \\
\hline Cryptophagidae & Atomariinae & Curelius japonicus & & & & & 1 & \\
\hline Languriidae & Xenoscelinae & Loberus species & & & & & 1 & \\
\hline Erotylidae & & Iphiclus sedecimguttatus & & 1 & & & & \\
\hline Endomychidae & Merophysinae & Holoparamecus aelleni & & 1 & & & & \\
\hline Coccinellidae & Sticholotidinae & Coccidophilus cariba & & 1 & & & & \\
\hline Coccinellidae & Sticholotidinae & Delphastus catalinae & & & & 0 & & \\
\hline Coccinellidae & Sticholotidinae & Delphastus diversipes & & 1 & & & & 1 \\
\hline Coccinellidae & Sticholotidinae & Delphastus pallidus & & & & 0 & & \\
\hline Coccinellidae & Sticholotidinae & Delphastus pusillus & & & & 0 & & \\
\hline Coccinellidae & Sticholotidinae & Delphastus quinculus & & & & 0 & & \\
\hline Coccinellidae & Scymninae & Clitostethus dispar & & 1 & & 1 & & \\
\hline Coccinellidae & Scymninae & Cryptolaemus montrouzieri & & & & 0 & & \\
\hline Coccinellidae & Scymninae & Decadiomus hughesi & & & & 0 & & \\
\hline Coccinellidae & Scymninae & Diomus ochroderus & & 1 & & & & \\
\hline Coccinellidae & Scymninae & Diomus roseicollis & & 1 & & 1 & & \\
\hline Coccinellidae & Scymninae & Hyperaspis connectens & & & & & 1 & 1 \\
\hline Coccinellidae & Scymninae & Hyperaspis donzeli & & & & & & 0 \\
\hline Coccinellidae & Scymninae & Hyperaspis festiva & & 1 & & 0 & & \\
\hline Coccinellidae & Scymninae & Hyperaspis pseudodonzeli & & 1 & & & & 0 \\
\hline Coccinellidae & Scymninae & Hyperaspis scutifera & & 1 & & & & \\
\hline Coccinellidae & Scymninae & Nephaspis bootes & & 1 & & & & \\
\hline Coccinellidae & Scymninae & Nephaspis oculata & & 0 & & 0 & & \\
\hline Coccinellidae & Scymninae & Scymnus floralis & & 1 & & 0 & 1 & 1 \\
\hline Coccinellidae & Scymninae & Stethorus albipes & & & & & & 1 \\
\hline Coccinellidae & Scymninae & Stethorus pseudocaribus & & & 1 & & & \\
\hline Coccinellidae & Chilochorinae & Chilocorus cacti & & & & 0 & & 1 \\
\hline Coccinellidae & Coccidulinae & Pseudoazya trinitatis & & & & & & 1 \\
\hline Coccinellidae & Coccidulinae & Rodolia cardinalis & & & & 0 & & \\
\hline Coccinellidae & Coccinellinae & Cheilomenes sexmaculata & & 1 & & & & \\
\hline Coccinellidae & Coccinellinae & Coleomegilla maculata & 0 & 1 & & 0 & & \\
\hline Coccinellidae & Coccinellinae & Cycloneda devestita & 0 & 0 & 1 & & & \\
\hline Coccinellidae & Coccinellinae & Cycloneda sanguinea & & 1 & 1 & 0 & 0 & 1 \\
\hline Coccinellidae & Coccinellinae & Psyllobora lineola & & & & & 1 & \\
\hline Coccinellidae & Coccinellinae & Psyllobora parvinotata & & & & 0 & & \\
\hline Corylophidae & Peltodinae & Holopsis species & & & & & 1 & \\
\hline
\end{tabular}


Table 2. Coleoptera of the Dutch Antilles. "1" indicates a species record based on vouchers, "0" a record that is not based on vouchers. (cont.)

\begin{tabular}{|c|c|c|c|c|c|c|c|c|}
\hline Family & Subfamily & Species & Aruba & Curaçao & Bonaire & St. Martin & Saba & St. Eustatius \\
\hline Mycetophagidae & Mycetophaginae & Typhaea stercorea & & & & & & 1 \\
\hline Ciidae & Ciinae & Cis cf. creberrimus & & & & & & 1 \\
\hline Ciidae & Ciinae & Cis melliei & & & & & & 1 \\
\hline Ciidae & Ciinae & Cis species & & & & & 1 & \\
\hline Mordellidae & Mordellinae & Glipostenoda pallida & & & & & & 1 \\
\hline Tenebrionidae & Lagriinae & Rhypasma mariagratiae & & 1 & 1 & & & \\
\hline Tenebrionidae & Lagriinae & Rhypasma venezuelense & & & 0 & & & \\
\hline Tenebrionidae & Pimeliinae & Ecnomosternum vermiculatum & & 1 & 1 & & & \\
\hline Tenebrionidae & Pimeliinae & Epitragus aurulentus & 1 & 1 & & & & \\
\hline Tenebrionidae & Pimeliinae & Epitragus hummelincki & 1 & & & & & \\
\hline Tenebrionidae & Pimeliinae & Stictoderia gridelli & 1 & & & & & \\
\hline Tenebrionidae & Pimeliinae & Stictoderia subseriata & & 1 & 1 & & & \\
\hline Tenebrionidae & Pimeliinae & Tapinocomus subnudus & 1 & 1 & 1 & & & \\
\hline Tenebrionidae & Pimeliinae & Trientoma guadeloupensis & & & & & & 1 \\
\hline Tenebrionidae & Diaperinae & Adelina pici & & & & & & 1 \\
\hline Tenebrionidae & Diaperinae & Phaleria fulva & & & & 1 & & 1 \\
\hline Tenebrionidae & Diaperinae & Phaleria picipes & & & & 1 & & 1 \\
\hline Tenebrionidae & Diaperinae & Phaleria punctipes & & & & 1 & & \\
\hline Tenebrionidae & Diaperinae & Phaleria species & 1 & & & & & \\
\hline Tenebrionidae & Diaperinae & Phaleria testacea & & & & 1 & & 1 \\
\hline Tenebrionidae & Diaperinae & Trachyscelis aphodioides & & & & 1 & & 1 \\
\hline Tenebrionidae & Diaperinae & Ulomoides ocularis & & & & 1 & & \\
\hline Tenebrionidae & Opatrinae & Blapstinus buqueti & 1 & 1 & 1 & & & \\
\hline Tenebrionidae & Opatrinae & Blapstinus curassavicus & & 1 & 1 & & & \\
\hline Tenebrionidae & Opatrinae & Blapstinus hummelincki & & 1 & 1 & & & \\
\hline Tenebrionidae & Opatrinae & Blapstinus opacus & & & & 1 & & 1 \\
\hline Tenebrionidae & Opatrinae & Blapstinus orchilensis & 1 & 1 & 1 & & & \\
\hline Tenebrionidae & Opatrinae & Diastolinus leewardensis & & & & & 1 & 1 \\
\hline Tenebrionidae & Opatrinae & Diastolinus perforatus & & & & 1 & & \\
\hline Tenebrionidae & Opatrinae & Goajiria curta & 1 & 1 & 1 & & & \\
\hline Tenebrionidae & Opatrinae & Nevisia barbudensis & & & & & 1 & \\
\hline Tenebrionidae & Opatrinae & Opatrinus clathratus & & & & 0 & & 1 \\
\hline Tenebrionidae & Opatrinae & Ulus hirsutus & 1 & & & & & \\
\hline Tenebrionidae & Tenebrioninae & Alphitobius laevigatus & 1 & 1 & & 1 & 1 & \\
\hline Tenebrionidae & Tenebrioninae & Hypogena biimpressa & & 1 & & & & \\
\hline Tenebrionidae & Tenebrioninae & Hypogena hirsuta & & 1 & & & & \\
\hline Tenebrionidae & Tenebrioninae & Hypogena tricornis & & 0 & & & & \\
\hline Tenebrionidae & Tenebrioninae & Palorus cerylonoides & & & & & & 1 \\
\hline Tenebrionidae & Tenebrioninae & Platydema species & & 1 & & & & \\
\hline Tenebrionidae & Tenebrioninae & Tribolium castaneum & & 1 & & & & \\
\hline Tenebrionidae & Tenebrioninae & Tribolium confusum & 1 & & & & & \\
\hline Tenebrionidae & Tenebrioninae & Trichoton curvipes & & 1 & & & & \\
\hline Tenebrionidae & Tenebrioninae & Zophobas atratus & 1 & 1 & 1 & 1 & 1 & 1 \\
\hline Tenebrionidae & Alleculinae & Lobopoda species & & & & & & 1 \\
\hline Anthicidae & Anthicinae & Acanthinus trifasciatus & 1 & 1 & 1 & & & \\
\hline Anthicidae & insertae sedis & Atenizoides curacaoae & & 1 & & & & \\
\hline Aderidae & & Ganascus species & & & & & & 1 \\
\hline Scraptiidae & Anaspidinae & Anaspis species & & & & & 1 & \\
\hline Cerambycidae & Prioninae & Hovorodon maxillosum & & & & 1 & & \\
\hline Cerambycidae & Prioninae & Mallodon spinibarbe & 1 & 1 & 0 & & & \\
\hline Cerambycidae & Prioninae & Solenoptera chalumeaui & & & & 1 & & \\
\hline Cerambycidae & Cerambycinae & Achryson quadrimaculatum & 1 & 1 & & & & \\
\hline Cerambycidae & Cerambycinae & Achryson surinamum & 1 & 1 & 1 & 1 & & \\
\hline Cerambycidae & Cerambycinae & Anelaphus cinereus & & 0 & & & & \\
\hline Cerambycidae & Cerambycinae & Anelaphus curacaoensis & & 1 & & & & \\
\hline Cerambycidae & Cerambycinae & Anelaphus nanus & & & & 1 & & \\
\hline Cerambycidae & Cerambycinae & Caribbomerus attenuatus & & & & 1 & & \\
\hline Cerambycidae & Cerambycinae & Curtomerus flavus & 1 & 1 & 1 & 1 & 1 & \\
\hline Cerambycidae & Cerambycinae & Eburia bonairensis & & 1 & 1 & & & \\
\hline Cerambycidae & Cerambycinae & Eburia decemmaculata & & & & 1 & 0 & 1 \\
\hline Cerambycidae & Cerambycinae & Eburia thoracica & & 1 & & & & \\
\hline Cerambycidae & Cerambycinae & Elaphidion conspersum & & 1 & 1 & 1 & & \\
\hline Cerambycidae & Cerambycinae & Elaphidion curacaoae & & 1 & & & & \\
\hline Cerambycidae & Cerambycinae & Elaphidion glabratum & & & & 1 & 1 & 1 \\
\hline Cerambycidae & Cerambycinae & Elaphidion irroratum & 0 & 1 & 1 & 1 & & \\
\hline Cerambycidae & Cerambycinae & Heterachthes sablensis & 1 & & & & & \\
\hline
\end{tabular}


Table 2. Coleoptera of the Dutch Antilles. " 1 " indicates a species record based on vouchers, " 0 " a record that is not based on vouchers. (cont.)

\begin{tabular}{|c|c|c|c|c|c|c|c|c|}
\hline Family & Subfamily & Species & Aruba & Curaçao & Bonaire & St. Martin & Saba & St. Eustatius \\
\hline Cerambycidae & Cerambycinae & Methia necydalea & & & & 1 & 0 & 1 \\
\hline Cerambycidae & Cerambycinae & Methia trium & 1 & 1 & 1 & & & \\
\hline Cerambycidae & Cerambycinae & Mionochroma vittatum & & 1 & & & & \\
\hline Cerambycidae & Cerambycinae & Neoclytus araneiformis & & & & & 1 & \\
\hline Cerambycidae & Cerambycinae & Neocompsa cylindricollis & & & & 1 & 1 & 1 \\
\hline Cerambycidae & Cerambycinae & Nesanoplium puberulum & & & & & & 1 \\
\hline Cerambycidae & Cerambycinae & Oxymerus aculeatus & 1 & 1 & & 1 & & \\
\hline Cerambycidae & Cerambycinae & Stizocera curacaoae & & 1 & & & & \\
\hline Cerambycidae & Cerambycinae & Stizocera insolita & & 1 & & & & \\
\hline Cerambycidae & Cerambycinae & Trachyderes succinctus & & & & 1 & & \\
\hline Cerambycidae & Lamiinae & Amniscus praemorsus & & & & 1 & & \\
\hline Cerambycidae & Lamiinae & Amniscus similis & & & & & 1 & 1 \\
\hline Cerambycidae & Lamiinae & Desmiphora hirticollis & & 1 & & & & \\
\hline Cerambycidae & Lamiinae & Dorcasta dasycera & 1 & & & & & \\
\hline Cerambycidae & Lamiinae & Ecyrus hirtipes & & & & & 1 & 1 \\
\hline Cerambycidae & Lamiinae & Estoloides perforata & & 1 & & & & \\
\hline Cerambycidae & Lamiinae & Lagocheirus araneiformis & 1 & 1 & 1 & 1 & 0 & 1 \\
\hline Cerambycidae & Lamiinae & Leptostylopsis argentatus & & 1 & & & & \\
\hline Cerambycidae & Lamiinae & Lithargyrus guadeloupensis & & & & & 1 & \\
\hline Cerambycidae & Lamiinae & Nealcidion socium & & 1 & & & & \\
\hline Cerambycidae & Lamiinae & Nyssodrysina haldemani & & 1 & & & & \\
\hline Cerambycidae & Lamiinae & Psapharochrus circumflexus & & 1 & & & & \\
\hline Cerambycidae & Lamiinae & Styloleptus inermis & & & & & & 1 \\
\hline Cerambycidae & Lamiinae & Styloleptus posticalis & & & & & 1 & \\
\hline Cerambycidae & Lamiinae & Urgleptes cobbeni & & 1 & 1 & 1 & 1 & 1 \\
\hline Cerambycidae & Lamiinae & Urgleptes guadeloupensis & & 1 & & & & \\
\hline Cerambycidae & Lamiinae & Urgleptes hummelincki & 1 & & & & & \\
\hline Bruchidae & Pachymerinae & Caryedon gonagra & & 1 & & & & \\
\hline Bruchidae & Amblycerinae & Amblycerus dispar & & 1 & & & & \\
\hline Bruchidae & Amblycerinae & Amblycerus schwarzi & & 1 & & & & \\
\hline Bruchidae & Amblycerinae & Zabrotes achiote & 0 & 1 & 0 & & & \\
\hline Bruchidae & Bruchinae & Acanthoscelides desmanthi & & 1 & & & & 1 \\
\hline Bruchidae & Bruchinae & Acanthoscelides difficilis & & & & & & 1 \\
\hline Bruchidae & Bruchinae & Acanthoscelides flavescens & 1 & 1 & 1 & & & \\
\hline Bruchidae & Bruchinae & Acanthoscelides indigoferestes & & & & & & 0 \\
\hline Bruchidae & Bruchinae & Acanthoscelides macrophthalmus & & & 1 & & & \\
\hline Bruchidae & Bruchinae & Acanthoscelides pertinax & & 1 & & & & \\
\hline Bruchidae & Bruchinae & Acanthoscelides rufovittatus & & 1 & & & & \\
\hline Bruchidae & Bruchinae & Acanthoscelides species & & & & & & 1 \\
\hline Bruchidae & Bruchinae & Acanthoscelides zeteki & & 1 & & & & \\
\hline Bruchidae & Bruchinae & Callosobruchus maculatus & & & & 0 & & \\
\hline Bruchidae & Bruchinae & Megacerus tricolor & & 1 & & & & \\
\hline Bruchidae & Bruchinae & Mimosestes insularis & & 1 & & & & \\
\hline Bruchidae & Bruchinae & Mimosestes mimosae & 1 & 1 & 1 & & & \\
\hline Bruchidae & Bruchinae & Stator cearanus & & 1 & & & & \\
\hline Bruchidae & Bruchinae & Stator sordidus & & 1 & & & & \\
\hline Chrysomelidae & Cassidinae & Agenysa guianiensis & & 1 & & & & \\
\hline Chrysomelidae & Cassidinae & Chalepus sanguinicollis & & & & 0 & & \\
\hline Chrysomelidae & Cassidinae & Chelymorpha multipunctata & & & & 0 & 0 & \\
\hline Chrysomelidae & Cassidinae & Charidotella sexpunctata & & & & 0 & 0 & \\
\hline Chrysomelidae & Cassidinae & Hilarocassis exclamationis & & 0 & & & & \\
\hline Chrysomelidae & Galerucinae & Altica cf. occidentalis & & & & 0 & & \\
\hline Chrysomelidae & Galerucinae & Chaetocnema minutissima & & 1 & & & & \\
\hline Chrysomelidae & Galerucinae & Disonycha spilotrachela & & & & 0 & 0 & \\
\hline Chrysomelidae & Galerucinae & Omophoita albicollis & & & & 0 & 0 & \\
\hline Chrysomelidae & Galerucinae & Yingaresca spiloptera & & 0 & & & & \\
\hline Chrysomelidae & Eumolpinae & Colaspis musae & & & 1 & & & \\
\hline Chrysomelidae & Cryptocephalinae & Cryptocephalus krugi & & & & 0 & & 1 \\
\hline Brentidae & Cyladinae & Cylas formicarius & & 0 & & 1 & & 0 \\
\hline Brentidae & Trachelizinae & Nemocephalus monilis & & & & 1 & 1 & 1 \\
\hline Brentidae & Apioninae & Apion pilosum & & & & & & 1 \\
\hline Curculionidae & Dryophthorinae & Metamasius hemipterus & & & & & 0 & \\
\hline Curculionidae & Dryophthorinae & Rhynchophorus ferrugineus & 1 & 1 & & & & \\
\hline Curculionidae & Dryophthorinae & Scyphophorus acupunctatus & & 0 & & & & \\
\hline Curculionidae & Dryophthorinae & Sitophilus linearis & & 1 & & & & 1 \\
\hline Curculionidae & Dryophthorinae & Sitophilus oryzae & & & & 0 & & 1 \\
\hline
\end{tabular}


Table 2. Coleoptera of the Dutch Antilles. " 1 " indicates a species record based on vouchers, "0" a record that is not based on vouchers. (cont.)

\begin{tabular}{|c|c|c|c|c|c|c|c|c|}
\hline Family & Subfamily & Species & Aruba & Curaçao & Bonaire & St. Martin & Saba & St. Eustatius \\
\hline Curculionidae & Curculioninae & Anthonomus cf. macromalus & & & & & & 1 \\
\hline Curculionidae & Curculioninae & Ceratopus species & & & & & 1 & \\
\hline Curculionidae & Curculioninae & Sibinia setosa & 0 & 1 & 0 & & & \\
\hline Curculionidae & Baridinae & Linogeraeus perscitus & & 1 & & & & \\
\hline Curculionidae & Cryptorhynchinae & species & & & & & & 1 \\
\hline Curculionidae & Cryptorhynchinae & Parisacalles species & & & & 1 & & \\
\hline Curculionidae & Cryptorhynchinae & Pseudomopsis species & & & & & 1 & \\
\hline Curculionidae & Entiminae & Apodrosus argentatus & & & & & & 1 \\
\hline Curculionidae & Entiminae & Artipus corycaeus & & & & & & 1 \\
\hline Curculionidae & Entiminae & Diaprepes abbreviatus & & & & 0 & & \\
\hline Curculionidae & Entiminae & Diaprepes famelicus & & & & & & 1 \\
\hline Curculionidae & Entiminae & Isodrusus curacaoensis & & 1 & & & & \\
\hline Curculionidae & Entiminae & Lachnopus curvipes & & & & & 1 & \\
\hline Curculionidae & Entiminae & Lachnopus valgus & & & & 1 & & \\
\hline Curculionidae & Entiminae & Lachnopus villosipes & & & & & & 1 \\
\hline Curculionidae & Entiminae & Lachnopus species & & & & & & 1 \\
\hline Curculionidae & Entiminae & Litostylus pudens & & & & & 1 & \\
\hline Curculionidae & Entiminae & Litostylus strangulatus & & & & & & 1 \\
\hline Curculionidae & Entiminae & Naupactus cervinus & & & 1 & & & \\
\hline Curculionidae & Lixinae & Microlarinus lypriformis & & 1 & & & & \\
\hline Curculionidae & Molytinae & Acorep species & & & & & & 1 \\
\hline Curculionidae & Molytinae & Anchonus cf. magister & & & & & & 1 \\
\hline Curculionidae & Molytinae & Decuanellus species & & & & & & 1 \\
\hline Curculionidae & Molytinae & Pseudoalaocybites aelleni & & 1 & & & & \\
\hline Curculionidae & Scolytinae & Ambrosiodmus hagedorni & & & & & 1 & \\
\hline Curculionidae & Scolytinae & Araptus insulanus & & 1 & & & & \\
\hline Curculionidae & Scolytinae & Coccotrypes advena & & & & & 1 & \\
\hline Curculionidae & Scolytinae & Coccotrypes carpophagus & & & & & 1 & \\
\hline Curculionidae & Scolytinae & Coccotrypes cyperi & & & & & 1 & \\
\hline Curculionidae & Scolytinae & Coccotrypes dactyliperda & & & & & 1 & \\
\hline Curculionidae & Scolytinae & Coccotrypes distinctus & & 1 & & & & \\
\hline Curculionidae & Scolytinae & Cryptocarenus heveae & & 1 & & & & \\
\hline Curculionidae & Scolytinae & Dryocoetoides capucinus & & & & & 1 & \\
\hline Curculionidae & Scolytinae & Hypocryphalus mangiferae & & & & & 1 & \\
\hline Curculionidae & Scolytinae & Hypothenemus africanus & & 1 & & & & \\
\hline Curculionidae & Scolytinae & Hypothenemus carinafrons & & 1 & & & & \\
\hline Curculionidae & Scolytinae & Hypothenemus crudiae & & & & & 1 & \\
\hline Curculionidae & Scolytinae & Hypothenemus eruditus & & & & & 1 & \\
\hline Curculionidae & Scolytinae & Hypothenemus exceptus & & 1 & & & & \\
\hline Curculionidae & Scolytinae & Hypothenemus glabratulus & & & & & 1 & \\
\hline Curculionidae & Scolytinae & Hypothenemus granulatus & & 1 & & & & \\
\hline Curculionidae & Scolytinae & Hypothenemus hampei & 1 & & & & & \\
\hline Curculionidae & Scolytinae & Hypothenemus interstitialis & & & & & 1 & \\
\hline Curculionidae & Scolytinae & Hypothenemus javanus & & 1 & & & & \\
\hline Curculionidae & Scolytinae & Hypothenemus leptosquamus & & 1 & & & & \\
\hline Curculionidae & Scolytinae & Hypothenemus obscurus & & 1 & & & 1 & \\
\hline Curculionidae & Scolytinae & Hypothenemus parvulosus & & & & & 1 & \\
\hline Curculionidae & Scolytinae & Hypothenemus ponticus & & 1 & & & & \\
\hline Curculionidae & Scolytinae & Hypothenemus pubescens & & & & & 1 & \\
\hline Curculionidae & Scolytinae & Hypothenemus rotundicollis & & 1 & & & 1 & \\
\hline Curculionidae & Scolytinae & Hypothenemus rubrithorax & & & & & 1 & \\
\hline Curculionidae & Scolytinae & Hypothenemus vernaculus & & 1 & & & & \\
\hline Curculionidae & Scolytinae & Hypothenemus villosus & & & & & & 1 \\
\hline Curculionidae & Scolytinae & Loganius ficus & & 1 & & & & \\
\hline Curculionidae & Scolytinae & Loganius vagabundus & & 1 & & & & \\
\hline Curculionidae & Scolytinae & Microborus iviei & & & & & 1 & \\
\hline Curculionidae & Scolytinae & Minyotrypetes primus & & 1 & & & & \\
\hline Curculionidae & Scolytinae & Neocultus thomasi & & 1 & & & & \\
\hline Curculionidae & Scolytinae & Phrixosoma antillicum & & & & & 0 & \\
\hline Curculionidae & Scolytinae & Pityophthorus minutissimus & & & & & 1 & \\
\hline Curculionidae & Scolytinae & Pseudothysanoes cracentis & & 1 & & & & \\
\hline Curculionidae & Scolytinae & Pycnarthrum hispidum & & 1 & & & 1 & \\
\hline Curculionidae & Scolytinae & Scolytodes glaber & & & & & 1 & \\
\hline Curculionidae & Scolytinae & Scolytodes pseudobicolor & & & & & 1 & \\
\hline Curculionidae & Scolytinae & Scolytodes sabaensis & & & & & 1 & \\
\hline Curculionidae & Scolytinae & Theoborus theobromae & & & & & 1 & \\
\hline
\end{tabular}


Table 2. Coleoptera of the Dutch Antilles. " 1 ” indicates a species record based on vouchers, “ 0 " a record that is not based on vouchers. (cont.)

\begin{tabular}{|c|c|c|c|c|c|c|c|c|}
\hline Family & Subfamily & Species & Aruba & Curaçao & Bonaire & St. Martin & Saba & St. Eustatius \\
\hline Curculionidae & Scolytinae & Xyleborus affinis & & & & & 1 & \\
\hline Curculionidae & Scolytinae & Xyleborus ferrugineus & & 1 & & & 1 & \\
\hline Curculionidae & Scolytinae & Xyleborus spinulosus & & & & & 1 & \\
\hline Curculionidae & Scolytinae & Xyleborus volvulus & & 1 & & & 1 & \\
\hline Curculionidae & Scolytinae & Xylosandrus compactus & & & & & 1 & \\
\hline Incertae sedis & & Cryptophagus forsstroemii & & & & & & 1 \\
\hline Incertae sedis & & "Dermestes" eustatius & & & & & & 1 \\
\hline \multicolumn{3}{|c|}{ Total number of species } & 50 & 131 & 38 & 65 & 89 & 96 \\
\hline
\end{tabular}

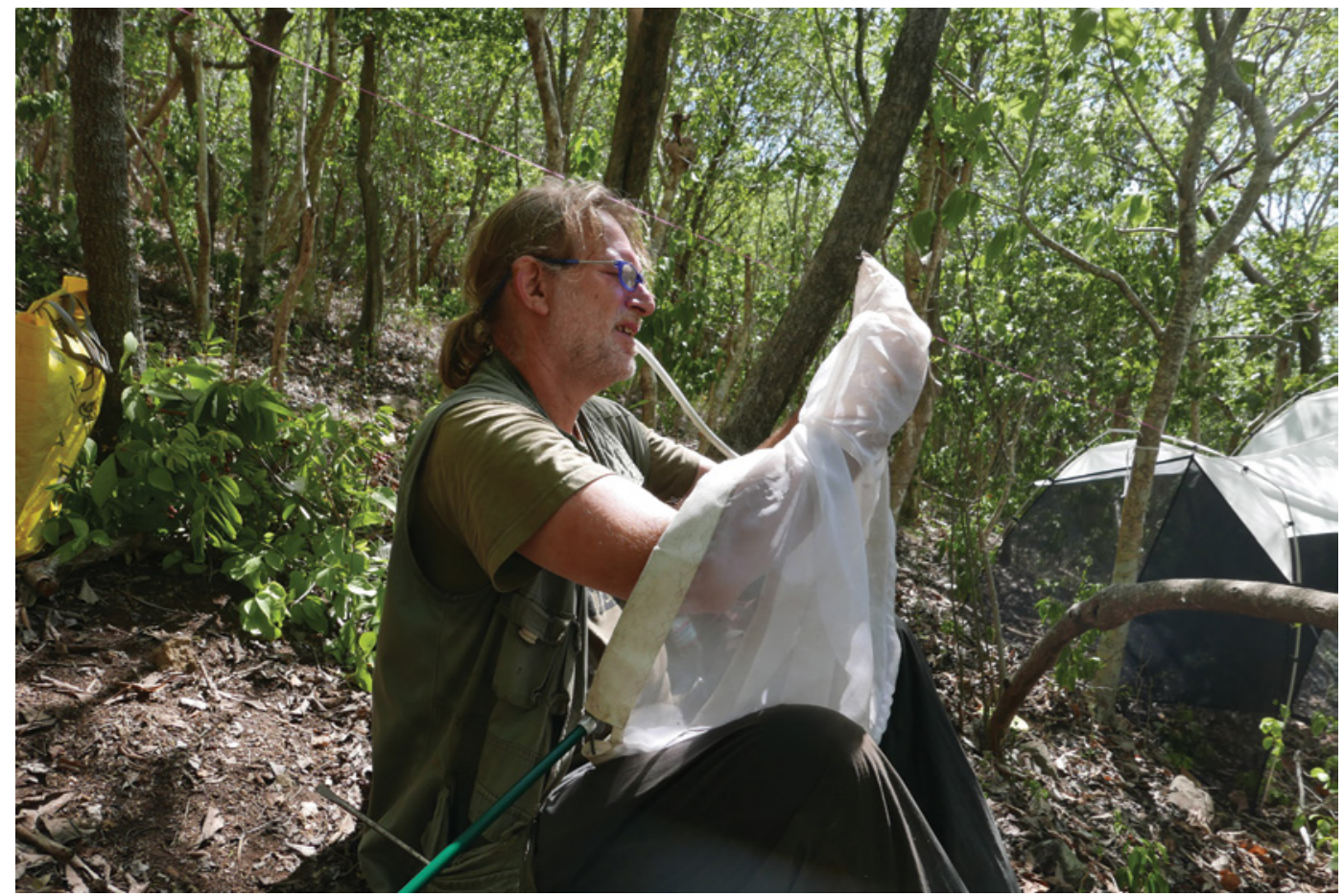

Figure 14. Ed Colijn sampling beetles in one of the plots at The Quill, St. Eustatius (4-x-2015). Photo: Elisabeth Haber.

History of beetle collecting in the Dutch Antilles The list of beetle collectors below offers an overview of beetle collecting and short biographies of those who visited the Dutch islands and collected beetles. Collectors of single specimens are only included in the species listings. The overview also contains information about important collections. Although a considerable number of people have been collecting Coleoptera on the islands, only a small part of these collections has actually been studied or published.

\section{Museum abbreviations}

American Museum of Natural History, New York (AMNH); British Museum of Natural History,
London (BMNH); C.A. Triplehorn Insect Collection, Ohio (OSUC); Canadian Museum of Nature, Ottawa (CMNC); Canadian National Collection of Insects, Ottawa (CNCI); Centre de Recherche Agronomique Antilles-Guyane, Guadeloupe (INRA-CRAAG); Doncaster Museum and Art Gallery, Doncaster (DMAG); E.H. Strickland Entomological Museum, Alberta (UASM); Field Museum of Natural History, Chicago (FMNH); Florida State Collection of Arthropods (FSCA); Hope Entomological Collections, University Museum of Natural History, Oxford (HEC); Insect Collection of the University of Puerto Rico, Mayagüez (EPRL); Musée Cantonal de Zoologie, Lausanne 


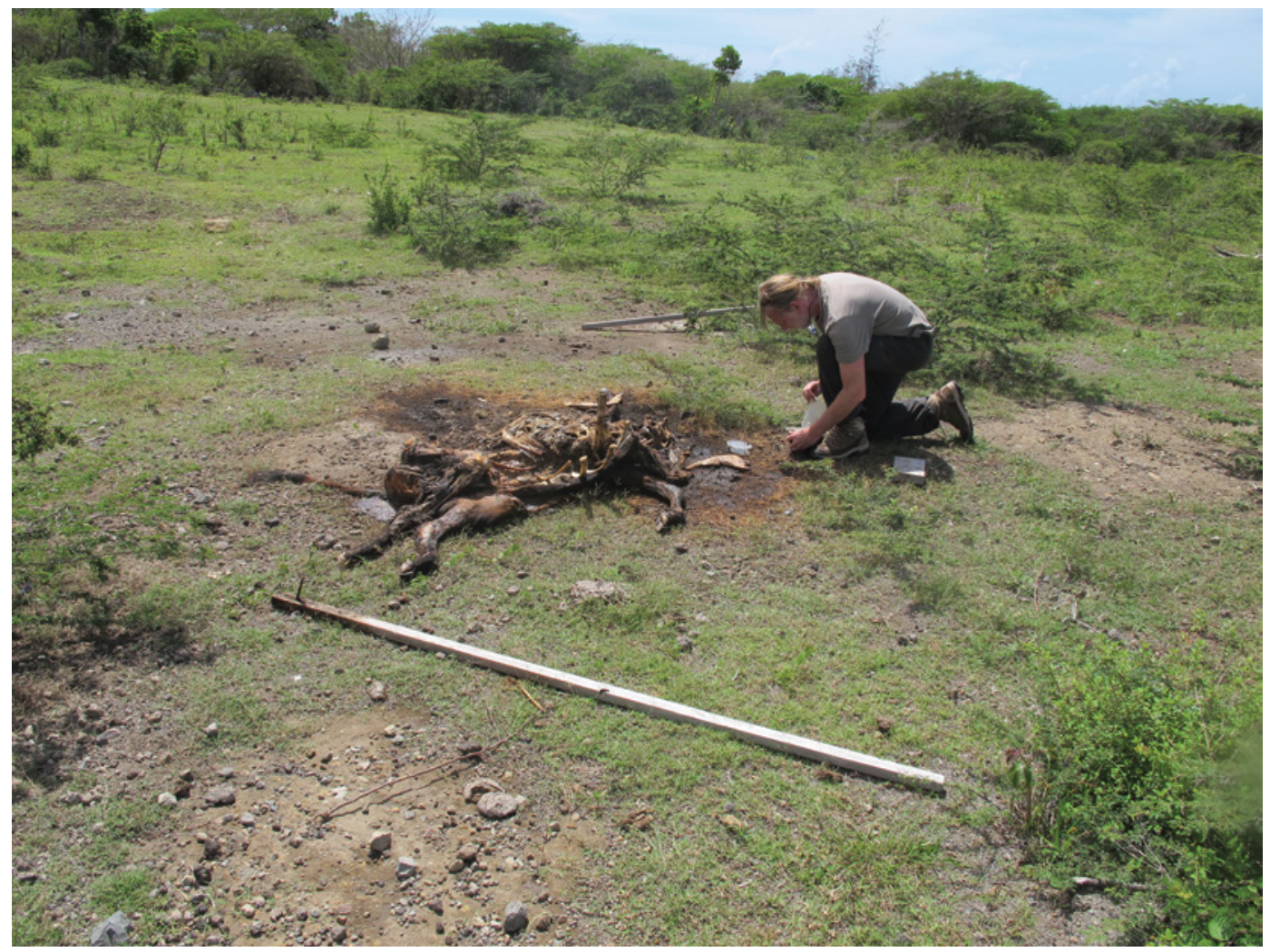

Figure 15. Collecting beetles from the corpse of a dead cow, Oranjestad, St. Eustatius (11-x-2015). Location of new island records for Dermestes maculatus, Necrobia rufipes and Omorgus suberosus. Photo: Roland Butôt.

(MZLS); Muséum d'Histoire Naturelle, Geneva (MHNG); Muséum National d'Histoire Naturelle, Paris (MNHN); Museum of Comparative Zoology, Cambridge (MCZC); National Museum of Natural History, Washington D.C. (USNM); Naturalis Biodiversity Center, Leiden (RMNH); Naturhistorisches Museum Wien (NHMW); Oklahoma Museum of Natural History (OMNH); Royal Belgian Institute of Natural Sciences, Brussels (RBINS); Senckenberg Deutsches Entomologisches Institut, Müncheberg (SDEI); Snow Entomological Museum Collection, Kansas (SEMC); Swedish Museum of Natural History, Stockholm (NHRS); University of Puerto Rico Mayagüez Invertebrate Collection (UPRM); University of the West Indies Zoology Museum, St. Augustine (UWIC); Uppsala University Museum of Evolution (UUZM); University of Georgia Collection of Arthropods (UGCA); West Indian Beetle Fauna Project, Montana (WIBF); Zoologisches Museum der Humboldt Universität, Berlin (ZMHB); Zoologisk Museum Copenhagen (ZMUC).

\section{Alphabetical index of collector abbreviations}

\begin{tabular}{lll}
\hline Abbreviation & Collector & Page \\
\hline ACJB & Burgers, Anton Cornelius Jacobus & 89 \\
AD & Delplanque, André & 91 \\
ADR & Ringma, Ab D. & 95 \\
AG & Gabriel, Alfons & 91 \\
AJW & Winter, Ton J. de & 96 \\
AS & Sallé, Auguste & 95 \\
AZ & Zanten, Ambrosius van & 97 \\
BAB & Barr, Barbara A. & 87 \\
BAB & Bitter, B.A. & 87 \\
BJ & Jong, B. de & 93 \\
BLC & Lalanne-Cassou, Bernard & 93 \\
BM & Malkin, Borys & 93 \\
BMR & Brother M. Realino & 87 \\
CD \& PD & Donneuve, C. \& P. & 91 \\
CTE & Epp, Carolus T. & 91 \\
CvdS & Sande, J.C.P.M. van de & 96 \\
DB & Bonnissent, Dominique & 87 \\
DBA & Bass, David & 86 \\
DE & Ébrard, David & 91 \\
DEB & Bright, Donald E. & 87 \\
DR & Rolander, Daniel & 95 \\
DSS & Sikes, Derek S. & 96 \\
DWB & Brzoska, David W. & 89 \\
EFB & Bugnion, Edouard Frédéric & 89
\end{tabular}




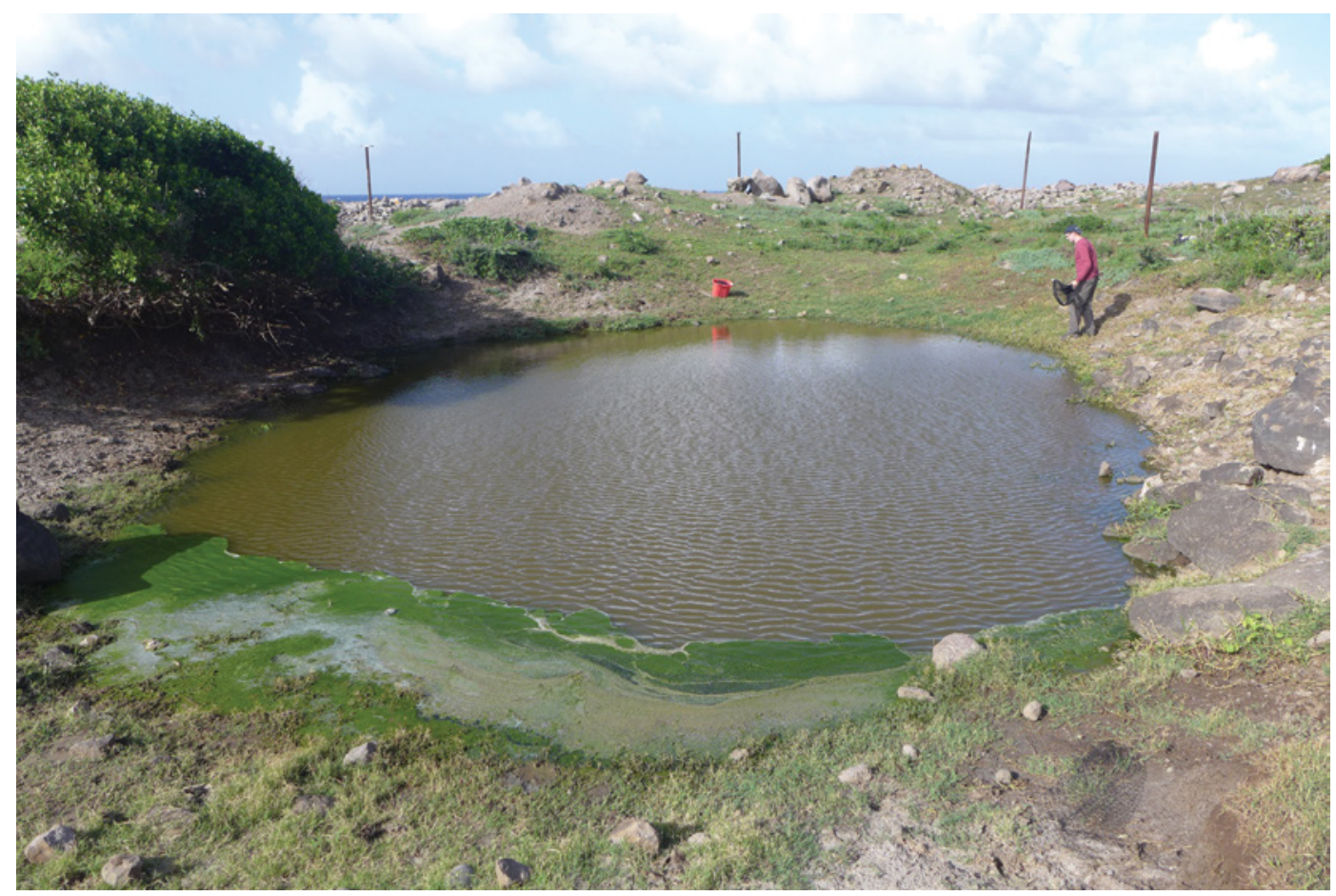

Figure 16. Kevin Beentjes sampling beetles from a small muddy pool at Venus Bay, St. Eustatius (10-x-2015). Location of new island records for Hydrophilus insularis. Photo: Berry van der Hoorn.

\begin{tabular}{lll}
\hline Abbreviation & Collector & Page \\
\hline EOC & Colijn, Ed O. & 97 \\
EP & Poirier, Eddy & 94 \\
ESPK & Pieters Kwiers, Edwin Simon & 94 \\
FC & Chalumeau, Fortuné & 89 \\
FDB & Bennett, Fred Douglas & 86 \\
FJS & Simmonds, Frederick J. & 96 \\
FM & MacKenzie, Faustino & 92 \\
FRP & Father Pinchon, Robert & 91 \\
GJHM & Molengraaff, Gerard Johan Hendrik & 93 \\
HBV & Venn, Helen B. & 86 \\
HER & Rijgersma, Hendrik Elingsz van & 95 \\
HFH & Heatwole, Harold F. & 92 \\
HJMG & Mac Gillavry, Henry James & 93 \\
HM & Madden, Hannah & 97 \\
HRA & Assour, Hannah R. & 86 \\
JAS & Jozef A. Slowik & 96 \\
JB & Brugge, Jeroen van der & 96 \\
JEB & Behm, Jocelyn E. & 86 \\
JEF & Forsström, Johan Erik & 91 \\
JFGC & Clarke, John Frederick Gates & 89 \\
JGB & Bergh, J.G. van den & 87 \\
JHPB & Bonfils, Jacques Henri Philippe & 87 \\
JHS & Stock, Jan H. & 97 \\
JJM & Mekkes, Jan-Joost & 93 \\
JKW & Winkelman, Jaap K. & 98 \\
JMC & Maldonado Capriles, Jenaro & 93 \\
JMS & Swearingen, Jil M. & 97 \\
JTS & Smit, John T. & 96 \\
JZ & Zijl, J. van & 98 \\
& &
\end{tabular}

KB
LJS
MAI
MB
MCT
MK
MPTG
MRDP
NVDP
PHD
PS
PWH
RF
RHC
RHT
RK
RMB
RSM
RV
SAM
STD
THB
VA
VHB
VZZ
WAJH
WAMJ
WES
Y
TH

Beentjes, Kevin 96

Steen, Louise J. van der 97

Ivie, Michael A. 92

Boeken, Michiel 87

Thomas, Michael C. 97

Kanters, Marijke 97

Gillett, Michael P.T. $\quad 91$

Díaz-Piferrer, Manuel R. $\quad 91$

Neervoort van de Poll, Jacobus

Rudolphus Hendrik 94

Dalens, Pierre Henry 89

Strinati, Pierre 86

Wagenaar Hummelinck, Pieter 97

Flachs, R. $\quad 91$

Cobben, René Hubert 89

Turnbow, Robert H. Jr. $\quad 97$

Krift, R. van der 93

Baranowski, Richard M. $\quad 86$

Miller, Richard S. \& Niki J. 93

Vogel, Rens 96

Marshall, Stephen A. 93

Danforth, Stuart Taylor 91

Burg, Thijs van den 96

Aellen, Villy 86

Bergh, V.H. van den 87

Dutch Mammal Society 96

Holleman, W.A.J. 92

Jesse, Wendy A.M. et al. 93

Steiner, Warren E. 97

Ypenburg, van 98 


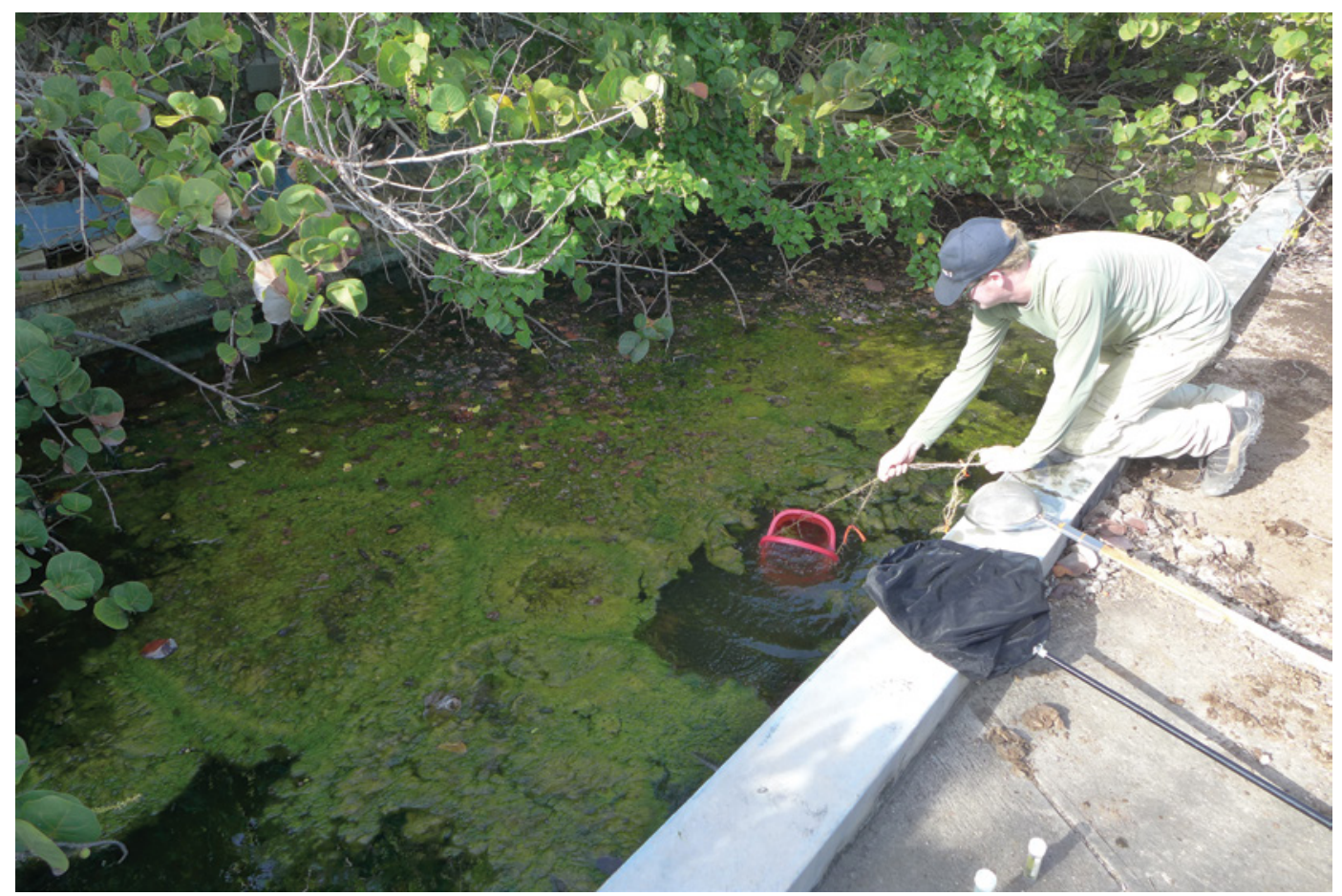

Figure 17. Kevin Beentjes sampling beetles from an overgrown swimming pool at an abandoned construction site near Zeelandia beach, St. Eustatius (8-x-2015). Location of new island record for Thermonectus circumscriptus and Tropisternus lateralis. Photo: Berry van der Hoorn.

\section{Biographies of collectors}

Aellen, Villy \& Strinati, Pierre (VA \& PS)

Swiss speleologists; conducted a biospeleological expedition in Aruba and Curaçao in 1985 and collected various cave-dwelling arthropods among which were at least two previously undescribed beetle species. Their collections are in MHNG (Rücker 1988, Osella 1989, Aellen \& Strinati 1997).

Baranowski, Richard M. \& Venn, Helen B. (RMB \& HBV)

Professor emeritus at the Department of Entomology \& Nematology of the University of Florida. Baranowski is a specialist on Heteroptera, especially those from South Florida and the Antilles. He, accompanied by his wife Helen, visited the Antilles as part of his research on the Lygaeidae of the West Indies (Baranowski \& Slater 2005). The Baranowskis also visited Saba in August 1992 where they collected at least one beetle (Ivie et al. 2008a, Shpeley et al. 2017).

\section{Bass, David (DBA)}

Professor of biology and curator of invertebrates at the University of Central Oklahoma. Bass visited several Caribbean islands including Saba (in 1999 and 2006) to study aquatic macroinvertebrates. Specimens from these studies have been deposited in OMNH (Bass 2008, 2020).

Behm, Jocelyn E. \& Assour, Hannah R. (JEB \& HRA) (Fig. 18)

Biologist Jocelyn Behm and undergraduate student biology Hannah Assour from the Center for Biodiversity at Temple University, Philadelphia, sampled invertebrates on Curaçao in 2017 and reported the first sighting of Cheilomenes sexmaculata on the island (Assour \& Behm 2019).

\section{Bennett, Fred Douglas (FDB)}

Entomologist and director of the Commonwealth Institute of Biological Control in Trinidad. In 1985 he left the institute for the University of Florida. Bennett visited several Caribbean islands including Curaçao. Due to a delayed flight Bennett was obliged to overnight on Curaçao in 1984. While there, he collected Microlarinus lypriformis near the airport for the first time for the island (Bennett 1985, 1989, 2020). 


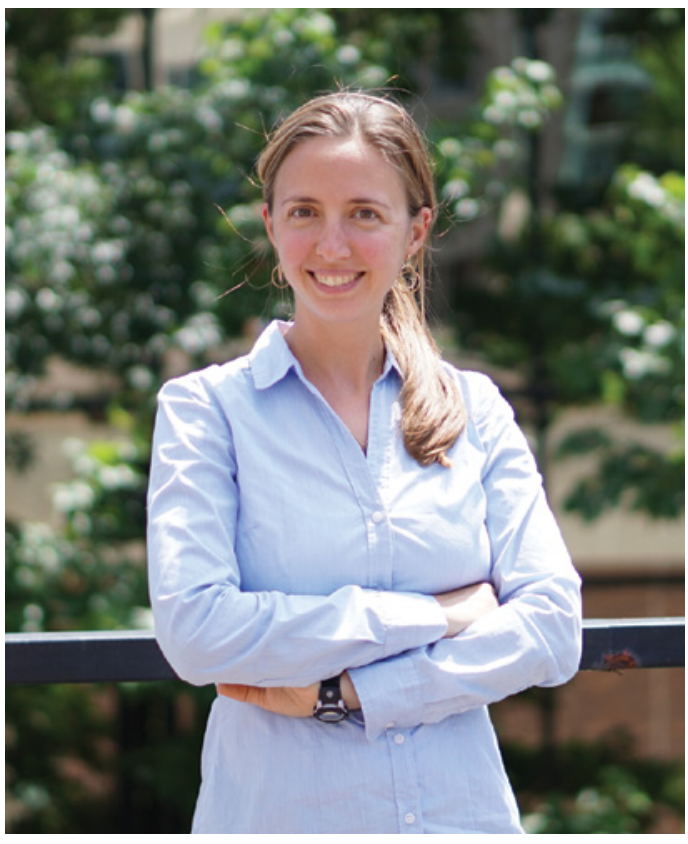

Figure 18. Jocelyn E. Behm. Photo: Tyler J. Tran.

\section{Bergh, J.G. van den (JGB)}

Teacher on Aruba. Collected all kinds of natural history specimens. Collection in RMNH (Wagenaar Hummelinck 1961, Marcuzzi 1962, Ball \& Shpeley 1992).

\section{Bergh, V.H. van den (VHB)}

Dutch chemist working for the Curaçaosche Petroleum Industrie Maatschappij. He advised Wagenaar Hummelinck during his first expedition and collected at least one beetle during this expedition (Rutten 1932, Gilmour 1968).

\section{Bitter, B.A. (BAB)}

Veterinary officer for the Government of the Netherlands Antilles. Member of the board of the "Vereniging van Bijenhouders op Curaçao" (Society of Bee Keepers on Curaçao) and member of the Natural Sciences Study Group Netherlands Antilles. Collected at least one longhorn beetle on Curaçao (Bitter 1949, Baumhover et al. 1955, Voous 1957, Gilmour 1968).

\section{Boeken, Michiel (MB) (Fig. 19)}

Dutch biologist who worked as a school director on Saba from August 2010 till July 2012. In his spare time he studied the breeding biology of red-billed tropicbirds (Phaethon aethereus), set up a monitoring programme for the orchid Brassavola cucullata and published an illustrated checklist of the island's orchid species and a checklist to the birds of Saba. Boeken returned to Saba in 2019-2020 for a followup on his red-billed tropicbird study. Boeken also collected beetles which are part of the collection of RMNH. Those collected during his most recent 2019-2020 trip are in the private collection of the first author and as yet unidentified (Boeken 2014, 2018, Boeken in litt. 2019, 2020).

\section{Bonfils, Jacques Henri Philippe (JHPB)}

French entomologist who specialised in leafhoppers (Hemiptera); worked for the Institut National de la Recherche Agronomique (National Institut for Agricultural Research; INRA). Bonfils collected on St. Martin during the 1960s. His collections are currently housed in the INRA-CRAAG in Guadeloupe, part of which has been transferred to INRA-France (Villiers 1980a, Lhoste 1987, Chassain \& Touroult 2012, Peck et al. 2014).

\section{Bonnissent, Dominique (DB)}

French archaeologist who worked for the Institut National de Recherches Archéologiques Préventives (French National Insititute for Preventive Archaeological Research, INRAP), Lesser Antilles. Marcuzzi (2001) and Soldati \& Touroult (2014) listed some Tenebrionidae that were collected by her at the Hope Estate on St. Martin in 1995. The latter are in the private collection of Laurent Soldati (Bonnissent 2020).

\section{Bright, Donald E. \& Barr, Barbara A. (DEB \& $\mathrm{BAB})$}

Donald Bright is an American coleopterologist and one of the leading world authorities on the classification of Scolytinae. He is currently a faculty affiliate at Colorado State University in Fort Collins. Bright recently published a comprehensive monograph of the bark and ambrosia beetles of the West Indies. In the company of Barbara Barr, he collected beetles on Saba in April 2013 which are housed in CNCI and WIBF (Bright 2019).

\section{Brother M. Realino (BMR) (Fig. 20)}

Born Frederikus Johannes Antonius Janssen he received the monastery name Realino after joining the Congregation of Brothers of Our Lady Mother of Mercy in Tilburg, The Netherlands in 1908. After teaching in Tilburg for nine years he left for Curaçao where he became a teacher for another 43 years. Realino acquired great knowledge of the local flora and fauna. Although he was more of an academic than a field biologist (Wagenaar Hummelinck 1978) he did collect some beetles which are now in RMNH. Marcuzzi (2002) named Diastolinus realinoi after him. 


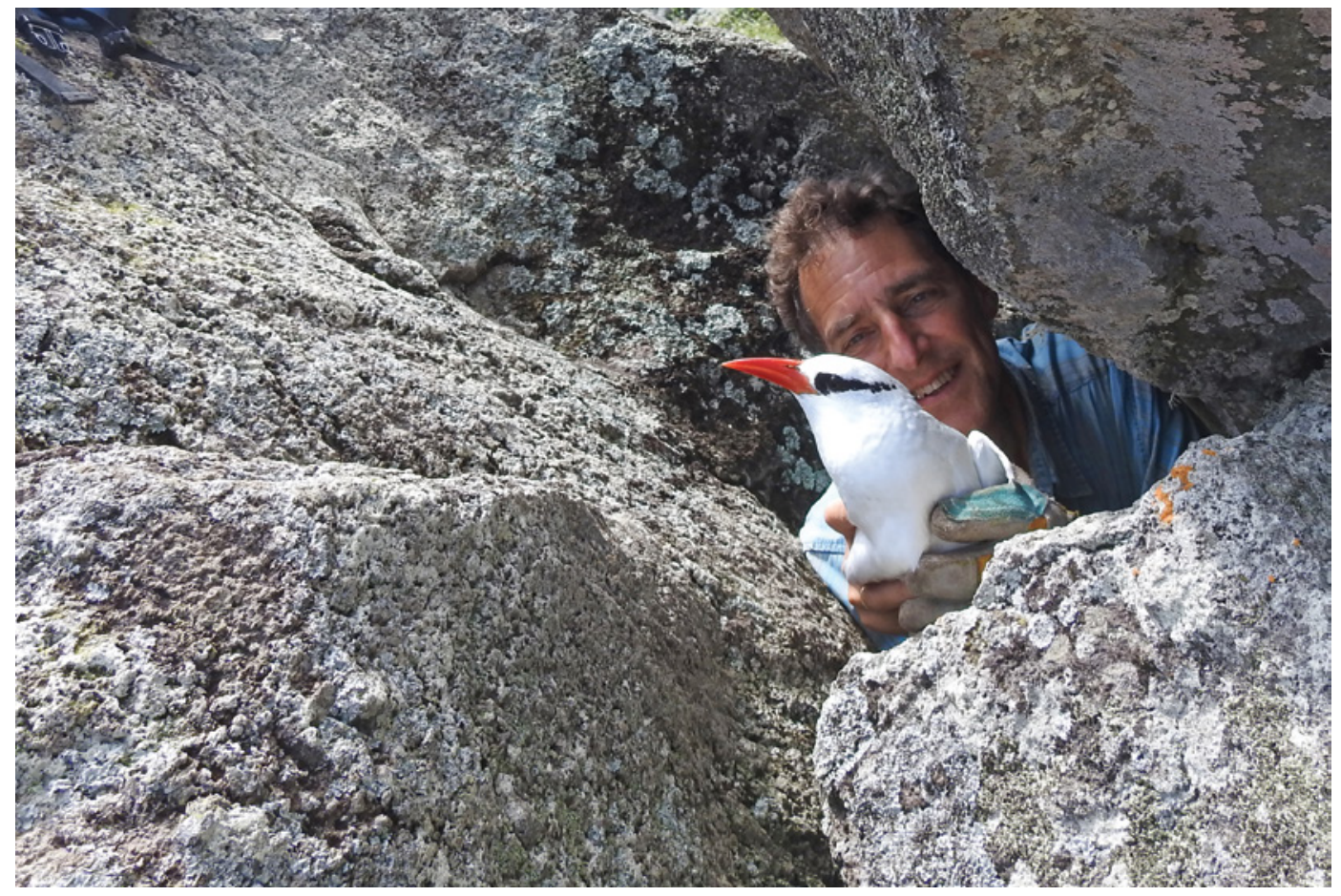

Figure 19. Boeken emerging with red-tailed tropicbird (Phaethon aethereus) on Saba. Photo: Mardik Leopold.

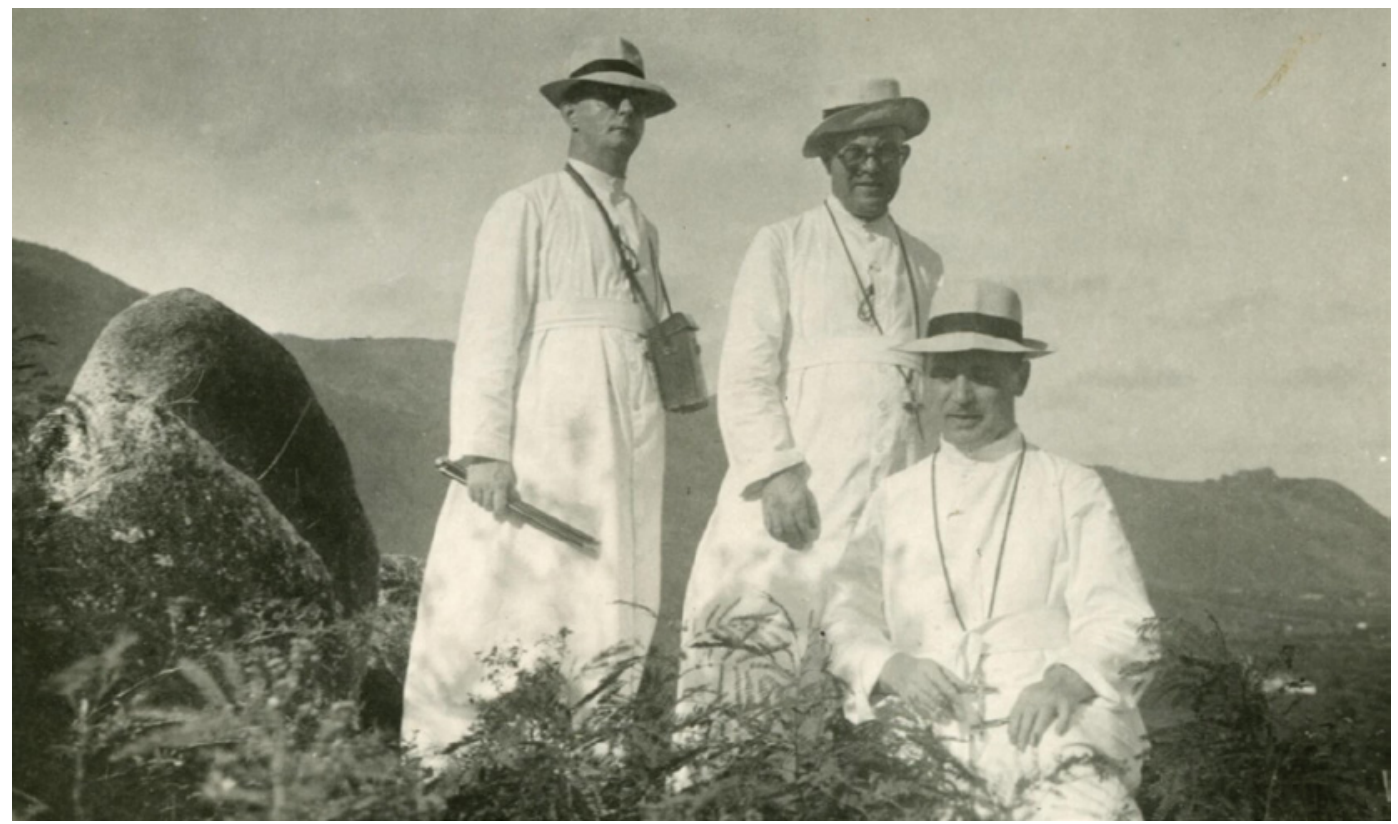

Figure 20. From left to right: brother Realino, brother Canutus en brother August on a study trip on St. Martin. Photo: collection Caribisch Erfgoed, Stadsmuseum Tilburg, The Netherlands. 


\section{Brzoska, David W. (DWB)}

Retired dentist with an M.Sc. in entomology and avid collector of Cicindelinae. His beetles are housed in SEMC and in his private collection. Brzoska collected in Bonaire in 1992 (Brzoska 2020, Thomas 2020).

\section{Bugnion, Edouard Frédéric (EFB) (Fig. 21)}

Swiss anatomist who, in addition to his work as a professor at the Institute of Anatomy of the Faculty of Medicine in Lausanne, published numerous articles on insects, especially ants and termites. In 1895-1896 he, together with Auguste Forel and Felix Santschi, travelled through Venezuela, Colombia and the Antilles, where Curaçao was visited (Sartori \& Cherix 1983). Part of the Coleoptera collected during this trip were published by Fauvel (1901) and Grouvelle \& Léveillé (1902, 1903). His collection is now probably housed in MZLS.

\section{Burgers, Anton Cornelius Jacobus (ACJB)}

Dutch endocrinologist; made a private collecting trip through the Antilles in the winter of 19481949. Like Wagenaar Hummelinck he worked at the Zoological Laboratory in Utrecht. Burgers collected insects in Bonaire, Curaçao, St. Eustatius, Saba and St. Martin (Burgers 1953, Gilmour 1968, Simon Thomas 1984). Collection in RMNH.

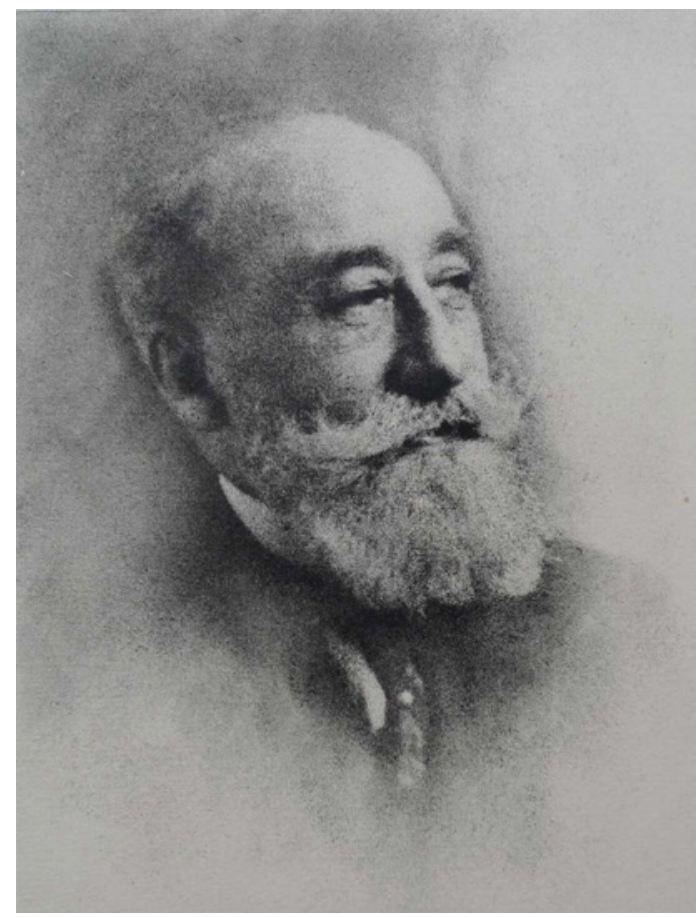

Figure 21. Bugnion. Portrait made by his wife Céline Laguarde in 1913.
Chalumeau, Fortuné (FC) (Fig. 22)

French entomologist and managing director of the Institute for Entomological Research in the Caribbean (IREC) in Guadeloupe. IREC was founded in 1978 by Fortuné Chalumeau and Jean-Pierre Camenen. The main purpose of the Institute is the systematic, ethological and biogeographical study of entomological taxa in the Caribbean and South America. Chalumeau published extensively on Caribbean beetles and graduated on a thesis on the Scarabaeoidea of the southern Antillean islands Guadeloupe, Dominica and Martinique. He visited St. Martin several times. His scientific collections are in INRA-CRAAG (Chalumeau 1983a, Peck 2016, Chalumeau 2020). His last and main entomological publication is "The Chiasognathinae of the Andes" (Chalumeau \& Brochier 2007). Chalumeau is a writer and historian too.

\section{Clarke, John Frederick Gates (JFGC)}

American entomologist specialised in Microlepidoptera. His early professional training and experience were in pharmacy but he later switched to zoology and entomology. Clarke collected on 30 Antillean islands among which was St. Martin. He visited the island during the second Bredin-Smithsonian Caribbean Expedition on 11-iv-1958 and 12-iv1958 (Schmitt 1958, Hodges 1991, Hart \& Ivie 2016). Beetles in the collections of USNM and WIBF.

Cobben, René Hubert (RHC) (Fig. 23)

Dutch entomologist specialised in Heteroptera; worked at the Laboratory for Entomology in Wageningen, The Netherlands. From September 1956 until July 1957 Cobben made a collection trip to the Dutch Antilles. He published a series of papers about the Heteroptera of the Dutch Antilles based on this expedition. Cobben not only collected bugs but also many beetles. Among these are the types of Elaphidion cobbeni Gilmour, 1963a [currently a synonym of Elaphidion glabratum (Fabricius, 1792a)], Caribbeana hebes Gilmour, 1963a [a synonym of Styloleptus inermis (Fabricius, 1801a)], Leptostyloides turbidus Gilmour, 1963b [a synonym of Amniscus similis (Gahan, 1895)] and Urgleptes cobbeni Gilmour, 1963b (Cobben 1960, de Vrijer 1988). Collection largely in RMNH; Gilmour's holotypes are in DMAG.

\section{Dalens, Pierre Henry (PHD)}

French physician working in French Guyana. Together with Stéphane Brûlé, Eddy Poirier (see there) and Julien Touroult he founded the Société Entomologique Antilles Guyane. Dalens collected on St. Martin in 2008 (Touroult 2019b, Dalens 2020, SEAG 2020). 


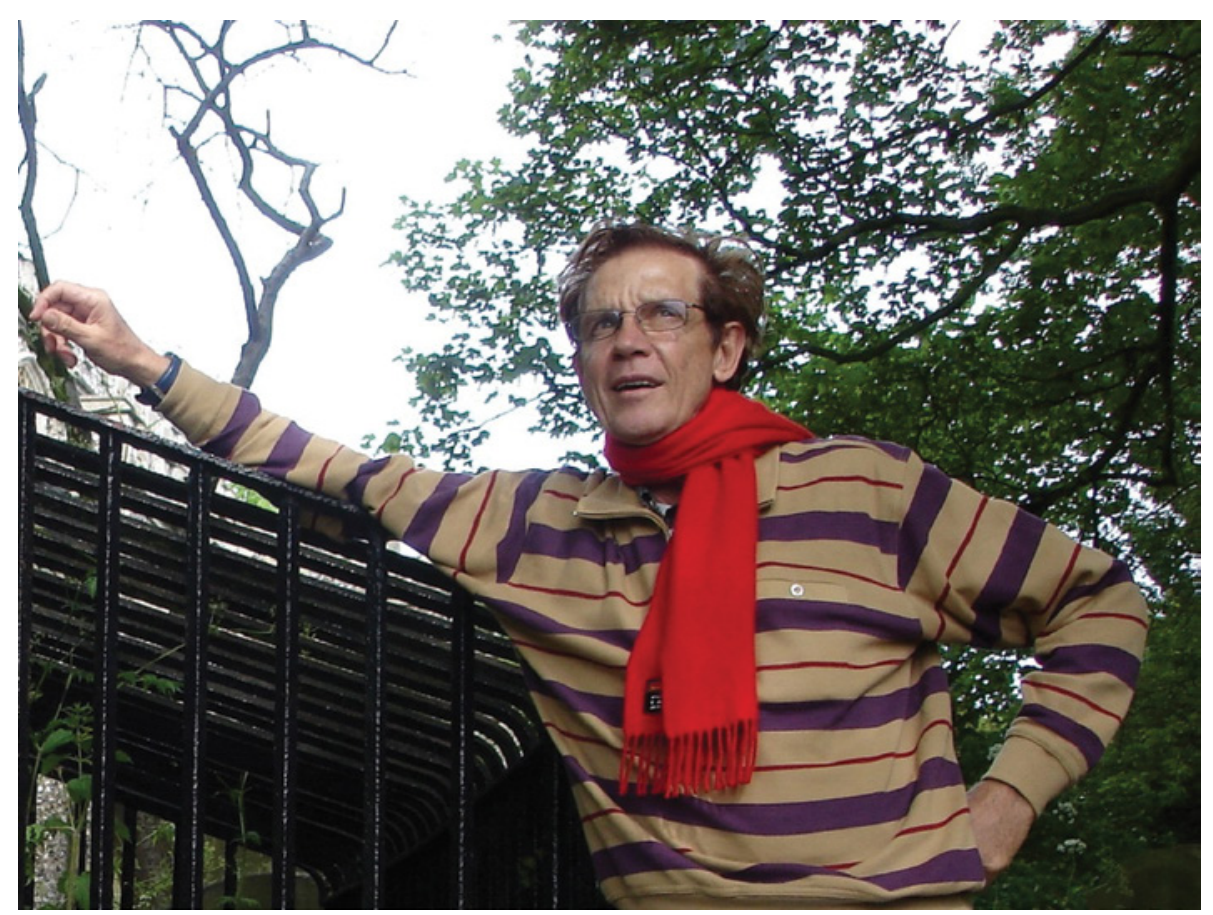

Figure 22. Fortuné Chalumeau.

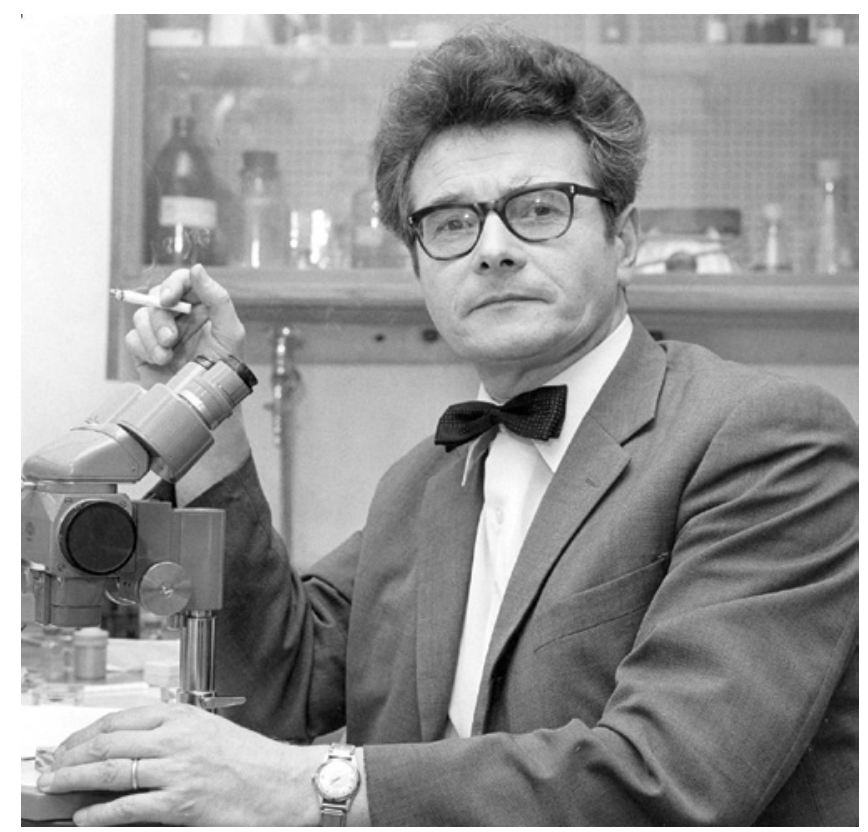

Figure 23. Cobben in 1978. Photo by unknown photographer. 


\section{Danforth, Stuart Taylor (STD)}

American professor in zoology and entomology at the University of Puerto Rico at Mayagüez. He travelled extensively throughout the Caribbean region until his untimely passing at the age of 38 (Franz \& Yusseff Vanegas 2009). Birds were his prime interest but Danforth also had a passion for entomology and established a sizeable collection of insects particularly strong in Coleoptera. He made a brief trip to St. Eustatius and St. Martin in NovemberDecember 1927. In January-February 1937 he travelled to Saba and St. Eustatius (Wetmore 1939, Voous 1955). On both journeys Danforth also collected beetles (see for instance Chalumeau \& Gruner 1977, Ball \& Shpeley 2009, Shpeley et al. 2017). Parts of his Dutch Antilles collection are in AMNH, EPRL, MCZC, MNHN, UASM and USNM.

\section{Delplanque, André (AD)}

French entomologist who worked for the French INRA in Guadeloupe in the 1970s. Delplanque visited St. Martin in 1970. Together with Fortuné Chalumeau he wrote a popular book about the insects of Guadeloupe and the neighbouring islands (Delplanque \& Chalumeau 1975, 1985, Chalumeau \& Gruner 1977, Skilling \& Batzer 1995, Chalumeau \& Touroult 2005).

\section{Díaz-Piferrer, Manuel R. (MRDP)}

Cuban phycologist and authority on Caribbean undersea botany. Worked at the University of Oriente, Cuba and later at the Department of Marine Sciences of the University of Puerto Rico. Visited the Leeward Antilles several times to study the local algal flora. Collected at least one longhorn beetle on Curaçao [Anonymous 1982, Philips \& Ivie 1998 (as M.D. Piterrer)].

\section{Donneuve, C. \& P. (CD \& PD)}

Collectors of the type specimen of "Helops martinensis" (see further there) and specimens of Zophobas atratus at Oyster Pond, St. Martin, all in the private collection of Laurent Soldati.

\section{Ébrard, David (DE)}

Listed as a collector of several longhorn beetles on St. Martin and Saba by Chalumeau \& Touroult (2005). We have not been able to find any additional information.

\section{Epp, Carolus T. (CTE)}

Lived on Curaçao from 1876 till 1886; member of the Curaçao Public Health Council and worked as chemist and meteorologist. Epp collected all kinds of natural history specimens including Coleoptera. After his return to the Netherlands he donated part of his collections to RMNH (Viana 1968, Fransen et al. 1997).

\section{Father Pinchon, Robert (FRP)}

Natural science professor at the diocesan college of Fort de France, Martinique. Pinchon was primarily active on Martinique where he collected all kinds of natural history specimens. At least in July 1953 he also visited St. Martin. His collections are in MNHN (Balazuc \& Chalumeau 1978, Chalumeau \& Gruner 1977).

\section{Flachs, R. (RF)}

Deputy director of the Curaçaosche Petroleum Industrie Maatschappij and avid advocate for the establishment of CARMABI on Curaçao. Collected some longhorn beetles on Curaçao among which two female paratypes of Lagocheirus araneiformis curacaoensis Gilmour, 1968 (Anonymous 1955, 1959, Gilmour 1968, Debrot \& Bak 2019). Part of the RMNH collection.

\section{Forsström, Johan Erik (JEF)}

Swedish pastor on St. Barthélemy from 1803 till 1815; also visited other islands in the region such as Saba and Guadeloupe (Urban 1902). On St. Eustatius Forsström collected a series of beetles new to science: Cryptophagus forsstromii Gyllenhal, 1808a [current taxonomic status unknown; types in UUZM (Wallin 2001) and NHRS (NHRS 2001)], Stelidota strigosa (Gyllenhal, 1808b) [type in NHRS (NHRS 2001)], Nitidula lusca Gyllenhal, 1808c [currently a synonym of Stelidota strigosa; type in NHRS (NHRS 2001)], Hyperaspis connectens (Thunberg, 1808) [type in NHRS (NHRS 2001)], Lachnopus villosipes (Boheman, 1834) [type in NHRS (NHRS 2001)] and Apion pilosum Gyllenhal, 1833 (current status and whereabouts of the type unknown). According to Horn \& Kahle (1935) Forsström's collection of Antillean insects travelled through the hands of G.J. Billberg and J.G. Children to finally end up in the BMNH in London.

\section{Gabriel, Alfons (AG)}

Austrian physician who worked on Bonaire from 1922 till 1925 (Wagenaar Hummelinck 1939). Gabriel collected a considerable number of natural history specimens including some Arthropoda. These were later studied by different specialists and published by Werner (1925). This collection is probably in the NHMW.

\section{Gillett, Michael P.T. (MPTG)}

English biochemist who works as a professor at the Saba University School of Medicine in The Bottom. Gillett was and is resident on Saba in 2006-2007 and from 2010 to the present. During this time he 
regularly collected beetles and other insects, partly assisted by Conrad P.D.T. Gillett. His Coleoptera are housed in his private collection and in $\mathrm{BMNH}$ (Gillett \& Gillett 2015, Gillett 2020).

\section{Heatwole, Harold F. \& MacKenzie, Faustino (also} written as McKenzie; HFH \& FM)

Harold F. Heatwole is an American ecologist who currently works as a professor at the Department of Zoology of North Carolina State University, Raleigh. His research encompasses both invertebrates and vertebrates. MacKenzie worked at the Institute of Neurobiology of the University of Puerto Rico and was Heatwole's research assistant. MacKenzie recently passed away. Heatwole and MacKenzie visited St. Martin in 1965. Their beetles are housed in WIBF (Heatwole et al. 1981, Hart \& Ivie 2016).

\section{Holleman, W.A.J. (WAJH)}

Author, wrote a popular school book about nature in the Dutch Antilles (Holleman 1952). Collected some beetles on Curaçao (Voous 1952, Gilmour 1968). These are in RMNH.

Ivie, Michael A. (MAI) (Fig. 24)

Associate Professor and Curator of Entomology in the Department of Plant Science and Plant Pathology at Montana State University which among other collections holds the important West Indian Beetle Fauna Project Collection. Ivie leads the West Indian Beetle Fauna Project at Montana State University, in cooperation with coleopterists world-wide. The project started in the late 1970s and continues. Ivie has visited all the northern Dutch Antilles although Saba was most extensively sampled. Along with Derek S. Sikes (see there), David Wagner and Piotr Nastrecki, Ivie visited Saba from 18 to 26 May 2008. Collections were made throughout the island using a variety of traps and added to those collected by Sikes and Jozef A. Slowik (see there) in March of that year, as well as material from traps running March to May. The beetles from these efforts, added to specimens collected by Borys Malkin 11-15 January 1968, and by Richard and Niki Miller's brief visit in March 1986, resulted in a list of nearly 300 species of beetles represented by over 3,200 specimens. Since that time, more material has been added from the collecting by Gillett and Bright. Specimens of other orders have not been studied, but are of a smaller extent. Ivie visited St. Eustatius on 27 and 28 May 2008, making small collections (est. 35 beetle species). Brief visits over the years to St. Maarten/ St. Martin and donations from collaborators have resulted in very limited holdings from that island. Ivie has published extensively on Caribbean beetles and the material from his work has been included in

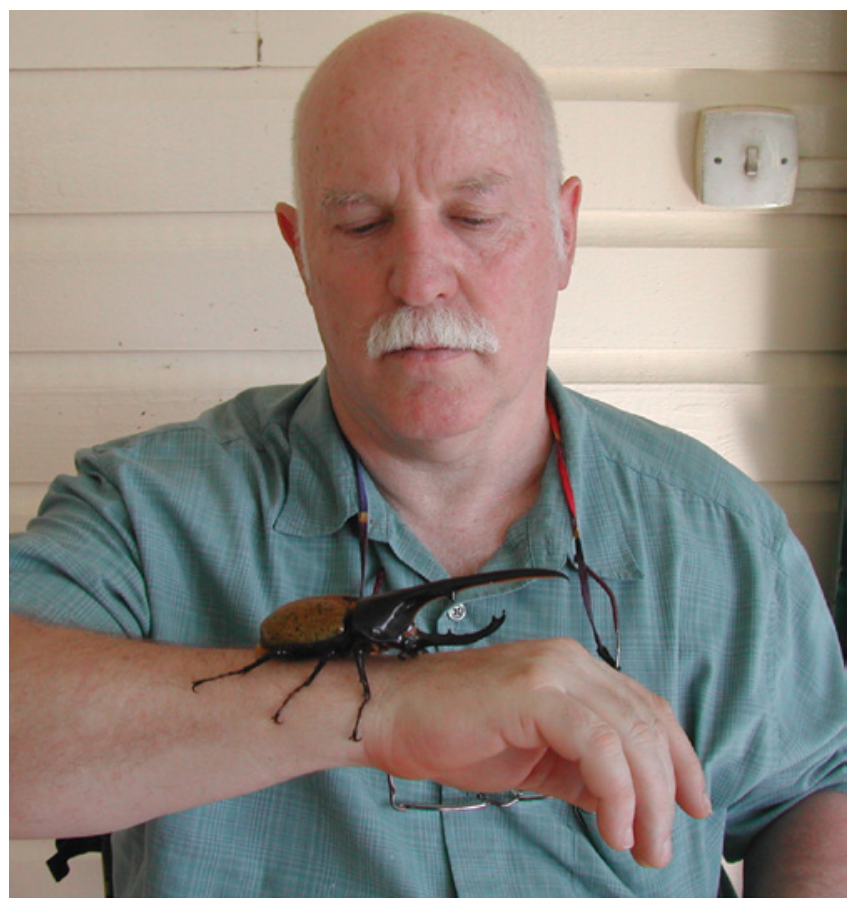

Figure 24. Ivie with Dynastes hercules on Dominica, June 2011. Photo: Donna Ivie. 
many other works (Maier \& Ivie 2013, Peck \& Cook 2014, Hart \& Ivie 2016, Shpeley et al. 2017, Bright 2019, Ivie in litt. 2020).

\section{Jesse, Wendy A.M. et al. (WAMJ)}

In 2016 Wendy Jesse, PhD biology student of the Vrije Universiteit Amsterdam, and colleagues studied the effects of the Coralita Antigonon leptopus invasion and urban development on the arthropod community composition on St. Eustatius. A small number of Coleoptera morphospecies were collected. These beetles are stored in the Caribbean Netherlands Science Institute on St. Eustatius (Jesse et al. 2020, Jesse in litt. 2020).

\section{Jong, B. de (BJ)}

Dutch biologist and longtime resident of Curaçao. There are Coleoptera in Dutch collections made by him from 1951 up to 1963 , mainly from Curaçao but also from Aruba. De Jong was secretary of the Natural Science Study Group of the Netherlands Antilles on Curaçao (van Heekeren 1960, McCrone \& Levi 1964). He did not only send material to the then Zoological Museum of Amsterdam but also directly to Gilmour (1968). The former Amsterdam specimens are now in $\mathrm{RMNH}$, those sent to Gilmour in DMAG.

\section{Krift, R. van der (RK)}

Collected beetles for Dré Teunissen while stationed at the marine base Suffisant at Curaçao in 1983. Dré Teunissen donated these beetles to the first author.

\section{Lalanne-Cassou, Bernard (BLC)}

Retired French lepidopterologist who works for the French INRA and the MNHN. Lalanne-Cassou lived on Guadeloupe for six years and visited St. Martin in 1983. He collected beetles on several Antillean islands (Zagatti et al. 1995-2006, Ivie et al. 2008a, Mantilleri 2014, Shpeley et al. 2017, Lalanne-Cassou 2020).

\section{Mac Gillavry, Henry James (HJMG)}

Henry James Mac Gillavry was the son of the Dutch brain surgeon and entomologist Donald Mac Gillavry. He joined Wagenaar Hummelinck on his first journey to the Antilles during a geological expedition to Aruba, Bonaire and Curaçao (Rutten 1932). Wagenaar Hummelinck paid special attention to the fauna of fresh and salt inland waters and the marine littoral area. Besides being a geology student, Henry James Mac Gillavry also had a keen interest in biology and added to Wagenaar Hummelinck's work by collecting land insects (Geijskes \& Wagenaar Hummelinck 1951, Skelton et al. 2013). Mac Gillavry (1934) also published a short paper about the insects of Curaçao. Collection in the RMNH.

\section{Maldonado Capriles, Jenaro (JMC)}

Puerto Rico-born entomologist and world authority on Miridae and Reduviidae (Heteroptera). Maldonado Capriles also studied Cicadellidae (Hemiptera) and Coleoptera (Scarabaeidae and Lymexylonidae). Blake (1965) named the Antillean chrysomelid beetle Syphrea maldonadoi after him. As far as the Dutch Antilles are concerned Maldonado collected beetles in Aruba, Bonaire and Curaçao in July 1962. His collection is in USNM (Kingsolver 1969, Santiago-Blay et al. 1997, Romero \& Johnson 2000).

\section{Malkin, Borys (BM) (Fig. 25)}

Belarus-born Polish-American ethnologist, naturalist, collector, traveller, photographer and filmmaker. Malkin collected beetles in the Philippines, New Guinea, Australia, Europe, Africa and America including the Antilles. Malkin collected for many musea. A large part of his collection of insects, including some of the Dutch Antilles, is kept at FMNH [Ivie et al. 2009, Bousquet 2012, Symbiota Collections of Arthropods Network (SCAN 2020)].

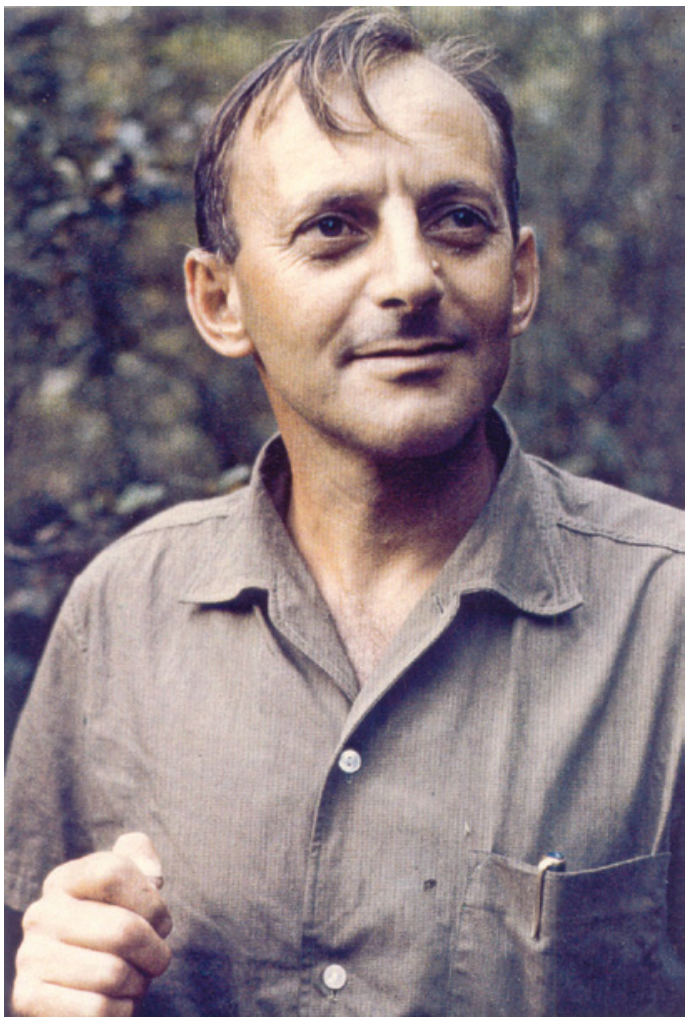

Figure 25. Malkin ca. 1975. Photo: Helena Malkin. Downloaded from Brill.com04/26/2023 08:17:17AM via free access 
Marshall, Stephen A. (SAM)

Canadian professor of entomology and director of the University of Guelph Insect Collection. Marshall paid a short visit to St. Martin in 1978. The beetles collected during this trip are in CMNC (Mantilleri 2014, Marshall in litt. 2018, Marshall 2020).

\section{Mekkes, Jan-Joost (JJM) (Fig. 26)}

Dutch entomologist specialising in Lepidoptera, Odonata and Orthoptera. Mekkes visited St. Eustatius for nearly two months in 2020. On his way to the island he also paid a week-long visit to St. Maarten. Mekkes collected invertebrates, including beetles, on both islands. His Coleoptera are currently in the possession of the first author but will eventually become part of the RMNH collection.

\section{Miller, Richard S. \& Niki J. (RSM)}

Visited Saba, and on their way also St. Martin, in March 1986. Their efforts yielded 32 species of beetles from Saba and at least one from St. Martin. Their collections were largely donated to WIBF. Their Tenebrionidae are in OSUC (Ivie et al. 2009, Hart \& Ivie 2016, SCAN 2020).

\section{Molengraaff, Gerard Johan Hendrik (GJHM)}

Dutch mining engineer who worked and lived on Curaçao from 1921 till 1927. Molengraaff studied fossils and also collected some beetles (Molengraaff 1929, Wagenaar Hummelinck 1955, Gilmour 1968). These are housed in RMNH.
Neervoort van de Poll, Jacobus Rudolphus Hendrik (NVDP) (Fig. 27)

Dutch entomologist, primarily interested in Coleoptera. At the end of 1884 he joined the geologist K. Martin and the botanist W.F.R. Suringar on a trip to Suriname and the Netherlands Antilles. From 9 January to 26 February 1885 the group visited Aruba (28 January-10 February), Bonaire (18-23 February) and Curaçao (9-28 January, 11-18 and 23-26 February). His collection was sold through O.E. Janson (London) often separately by family. Neervoort van de Poll described Tetracha curacaoica [currently a synonym of Megacephala gracilis (Dejean, 1825)] in his paper about the Cicindelinae of Curaçao (Martin 1885, 1888, Suringar 1885, 1886, Neervoort van de Poll 1886, Horn \& Kahle 1935, Fransen et al. 1997).

\section{Pieters Kwiers, Edwin Simon (ESPK)}

Antillean-born; studied tropical agriculture at the Wageningen University. Pieters Kwiers worked for the local Agricultural Services, assisted several zoologists on Bonaire and Curaçao and also collected himself (Cobben 1960, Gilmour 1968, Stock 1977). His beetles are in the RMNH collection.

\section{Poirier, Eddy (EP)}

French entomologist. Together with Stéphane Brûlé, Pierre Henry Dalens and Julien Touroult he founded the Société Entomologique Antilles Guyane. Poirier collected on St. Martin in 2015 (Lemaire 2017, SEAG 2020).

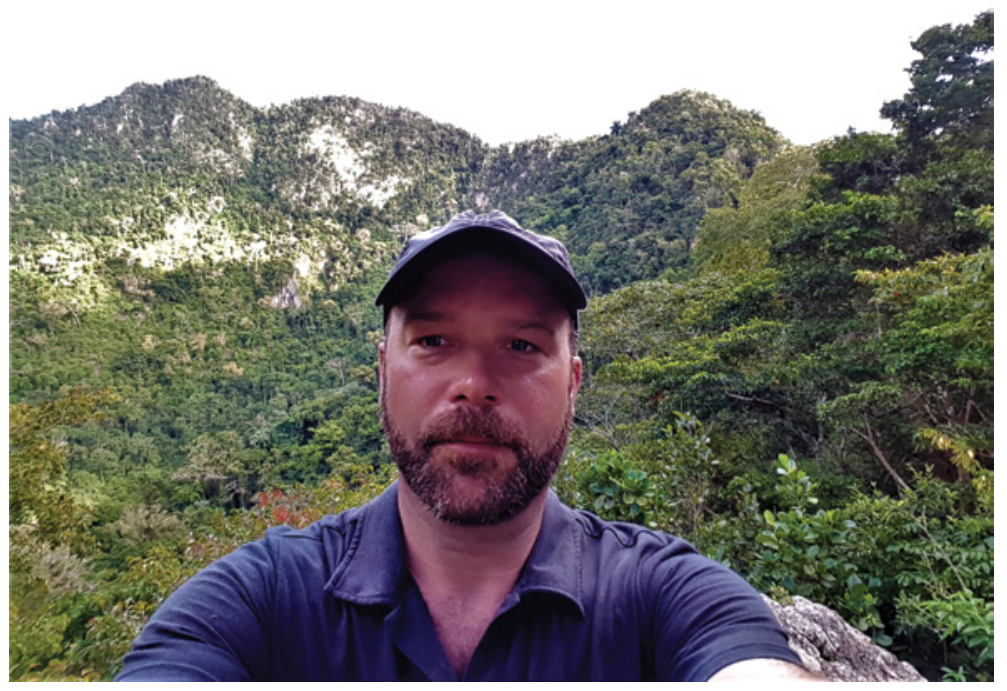

Figure 26. Jan-Joost Mekkes on the Quill, St. Eustatius. Photo: Jan-Joost Mekkes. 


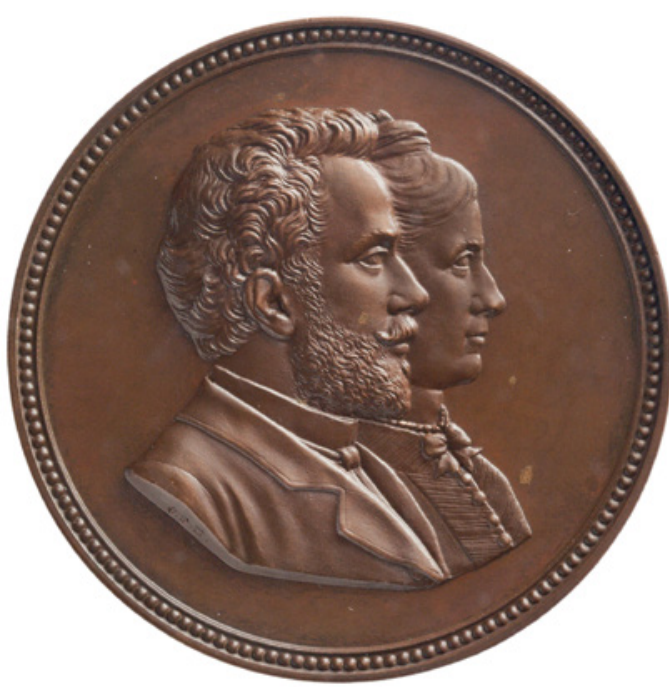

Figure 27. Neervoort van de Poll. Coin issued to commemorate the marriage of Jacobus Rudolph Hendrik Neervoort van de Poll with Marthe Jeannette Elsine Geertruijda Phillippine Zubli, 20-v-1887. Collection Tylers Museum, Haarlem, The Netherlands.

Rijgersma, Hendrik Elingsz van (HER) (Fig. 28) Dutch physician who worked for the government on St. Martin from 1863 until his death on 4 March 1877 at the age of 42 . His prime interest concerned Mollusca but Rijgersma collected all kinds of natural history specimens including beetles. Rijgersma also exchanged material with others among which was Abbé Kohlmann, a French catholic priest and entomologist specialising in Coleoptera who lived on both Guadeloupe and St. Martin (1867-1875). Rijgersma's collecting activities were not restricted to St. Martin. He also visited Anguilla, Saba, St. Eustatius and Redonda. His beetles are in RMNH and, except for some individual specimens, have not been revised (Holthuis 1959, 1961, Coomans 1974, Ehn \& Zanoni 2002). Coomans' paper offers a comprehensive review of Rijgersma's life and work.

\section{Ringma, Ab D. (ADR)}

Dutch pilot who worked at Hato airport, Curaçao. During the late 1940s until his departure to the Netherlands in 1951 he studied the caves of Curaçao, Aruba and Bonaire (Wagenaar Hummelinck 1951). Ringma also collected beetles which are in RMNH.

Rolander, Daniel (DR) (Fig. 29)

One of the apostles of Linnaeus and the first to visit St. Eustatius to collect beetles; arrived by ship from

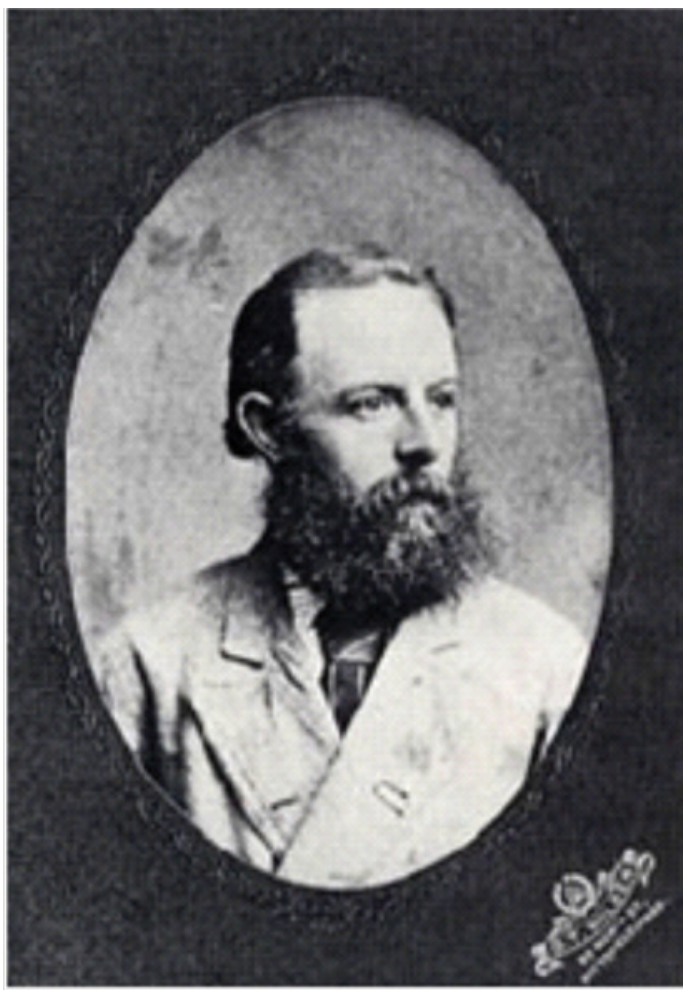

Figure 28. Van Rijgersma at the age of 38 .

Suriname on 12 February 1756 and left the island on 23 February 1756. During this short visit Rolander collected, among others, Dermestes eustatius Linnaeus, 1758, a taxon which according to Háva (2015) is not a dermestid beetle but a scolytine. The type is in de Charles de Geer collection in NHRS (Dobreff et al. 2009, Dobreff 2010) but its current taxonomic status is unclear.

\section{Sallé, Auguste (AS)}

French collector who, together with his mother and a friend of hers, regularly explored Mexico, the Antilles and South America. Salle's expeditions were financed by a group of investors, chiefly Louis Alexandre Auguste Chevrolat, who shared the collected insects among the shareholders. Sallés private collection was especially rich in species from Mexico, the Dominican Republic, Venezuela and the United States. It was sold at an auction by Émile Deyrolle in 1897. Most of his collection eventually ended up in the MNHN in Paris via entomologists like Fleutiaux, Grouvelle, Oberthür, Sédillot and Théry (Cambefort 2006). Among the Dutch Antilles, at least Curaçao was visited by Sallé. Mulsant \& Rey (1859) described Goajiria curta based on specimens collected on Curaçao by Sallé. 


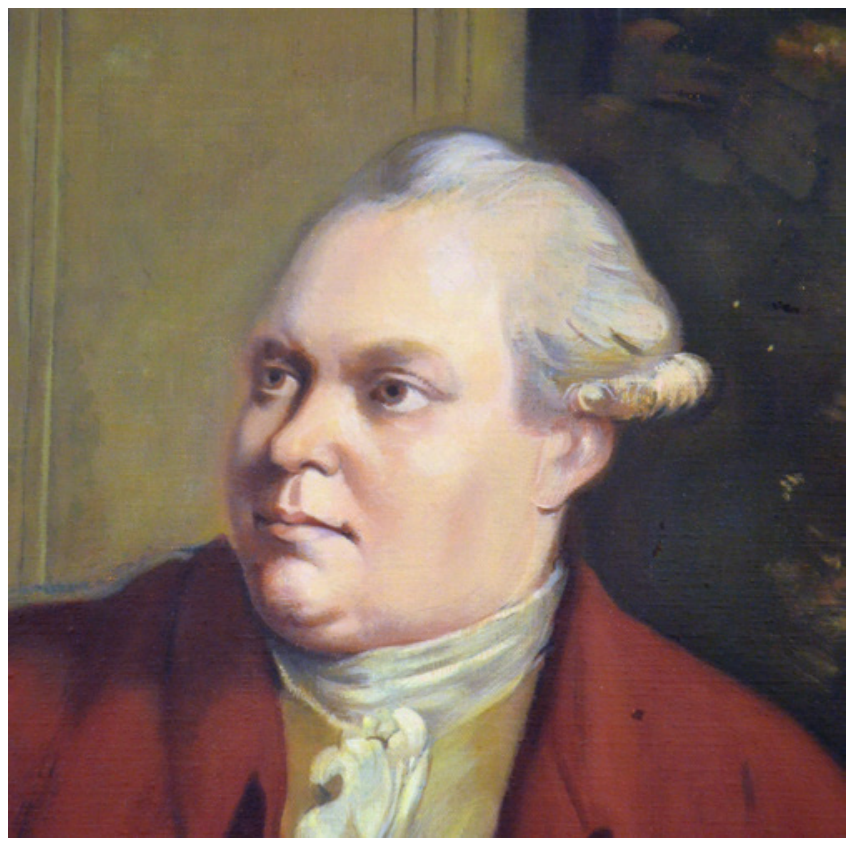

Figure 29. Daniel Rolander, detail of a painting by William Parry 1775 of Rolander and Joseph Banks and the Tahitian visitor Omai. Photo: Bengt Oberger.

\section{Sande, J.C.P.M. van de (CvdS)}

Dutch biologist with an interest in botany, beetles and aquatic macrofauna. Stayed at CARMABI in Curaçao during his study time from December 1975 till May 1976. His Coleoptera are in his private collection.

\section{Sikes, Derek S. (DSS)}

Curator of insects and professor of entomology at the University of Alaska Museum. World authority on Nicrophorinae, a subfamily of the Silphidae, a beetle family not represented in the Lesser Antilles. Along with Jozef A. Slowik (see there), Sikes visited Saba in March 2008 to collect invertebrates and set up traps. Both returned to the island in June of that year in the company of David Wagner, Piotr Nastrecki and Michael Ivie (see there) to pick up the traps and collect more invertebrates. About 3,000 beetle specimens were collected during these visits (Maier \& Ivie 2013, Peck \& Cook 2014, Hart \& Ivie 2016, Shpeley et al. 2017, Bright 2019, Ivie in litt. 2020, Sikes 2020b).

\section{Simmonds, Frederick J. (FJS)}

Director of the West Indian Station of the Commonwealth Institute of Biological Control; visited at least some of the Dutch Antilles in May 1954 during the course of a number of different Caribbean biological control projects and collected Coccinellidae and Bruchidae. The specimens reported upon by Bennett \& Simmonds (1964) are in BMNH, USNM and UWIC (Davey 1958, Gordon 1972, Gordon \& Chapin 1983).

\section{Slowik, Jozef A. (JAS)}

Insect collection research affiliate at the University of Alaska Museum. Slowik's focus is on spider taxonomy, life history, faunistics, and phylogeny, specifically that of the spider families Linyphiidae and Lycosidae. Along with Derek Sikes (see there) Joey Slowik visited Saba in March 2008 to collect invertebrates and set up traps. Both returned to the island in June of that year in the company of David Wagner, Piotr Nastrecki and Michael Ivie (see there) to pick up the traps and collect more invertebrates. About 3,000 beetle specimens were collected during these visits. Together with Derek Sikes, Slowik published an overview of the spider fauna of Saba (Slowik \& Sikes 2011, Maier \& Ivie 2013, Peck \& Cook 2014, Hart \& Ivie 2016, Shpeley et al. 2017, Bright 2019, Ivie in litt. 2020).

\section{St. Eustatius Scientific Terrestrial Expedition team (Fig. 30)}

Rens Vogel and Thijs van den Burg (students; RV, THB), mammalogists of the Dutch Mammal Society (Ellen van Norren, Sil Westra and Wesley Overman; VZZ), Jeroen van der Brugge (natural history educator; JB), John Smit (dipterologist; JTS), Kevin Beentjes (molecular biologist; KB), Ton de Winter 


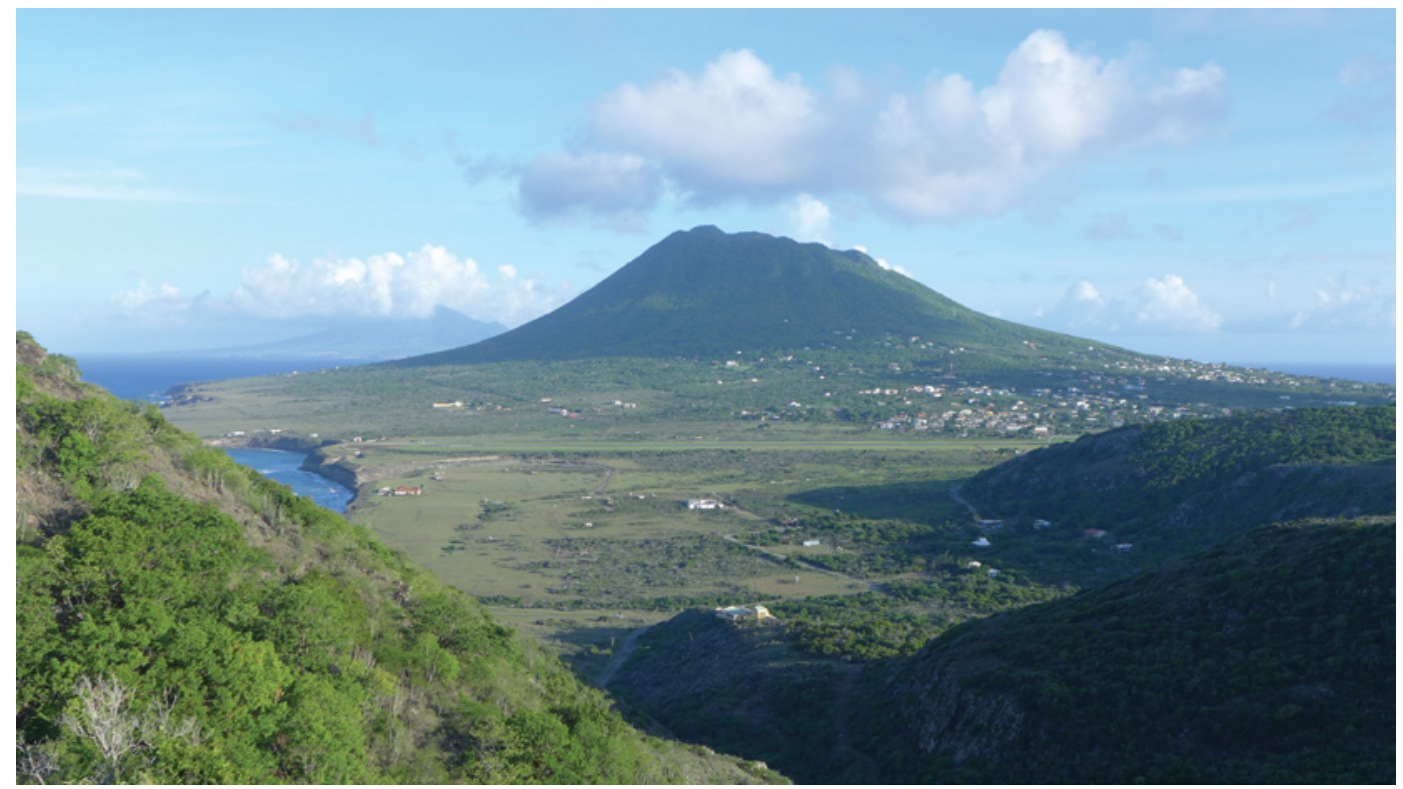

Figure 30. View from Boven National Park, St. Eustatius. From foreground to background: Zeelandia, airstrip, Oranjestad, the Quill. Photo: Berry van der Hoorn.

(malacologist; AJW), Marijke Kanters (nature photographer; MK), Hannah Madden (STENAPA; HM), Ambrosius van Zanten (STENAPA; AZ) and the first author (coleopterologist; EOC) collected beetles during the St. Eustatius Scientific Terrestrial Expedition outside the plots. These specimens are partly housed in the author's private collection and partly in RMNH.

\section{Steen, Louise J. van der (LJS)}

Secretary at the CARMABI institute and later in the Zoological Laboratory Utrecht. From 1958 on she co-edited the "Studies on the Fauna of Curaçao and other Caribbean Islands" together with P. Wagenaar Hummelinck. Van der Steen was also one of the editors of the journal "Nieuwe West-Indische Gids". A number of beetles collected by her in the CARMABI area on Curaçao are in the collection of RMNH (Gilmour 1968, Wagenaar Hummelinck 1968, 1982).

\section{Steiner, Warren E. \& Swearingen, Jil M. (WES \&} JMS)

Visited Curaçao in February 1987 and collected among other specimens the types of Cybocephalus caribaeus Smith, 2007 and the paratypes of Nephaspis bootes Gordon, 1997. Until his retirement in 2010, Steiner was responsible for the management of the Coleoptera collection of the USNM where his collections are also largely stored. Steiner also visited
Curaçao in 2014 in the company of M.C. Thomas and R.H. Turnbow (Gordon 1997, Philips \& Ivie 1998, Smith \& Cave, 2007, Grey \& Smith 2020, Steiner 2020).

\section{Stock, Jan H. (JHS)}

Dutch carcinologist and professor of zoology at the University of Amsterdam. Collected at least one longhorn beetle on Curaçao (Gilmour 1968, Anonymous 1997).

\section{Turnbow, Robert H. Jr. (RHT) \& Thomas, Michael C. (MCT)}

Robert Turnbow is an American entomologist working at Fort Tucker, Alabama. Michael Thomas is emeritus entomologist Coleoptera at FSCA. Both visited Curaçao in 2014 and 2015. Their Curaçao beetles are in Turnbow's private collection, FSCA and UGCA. Neorthopleura turnbowi from Curaçao and $N$. thomasi from the Cayman Islands and the Bahamas were recently named after them (Opitz 2019, Grey \& Smith 2020, UGCA 2020).

Wagenaar Hummelinck, Pieter (PWH) (Fig. 31) Probably the most active historic collector in the Antilles. Wagenaar Hummelinck worked at the Zoological Laboratory Utrecht and collected in all the Dutch Antilles as well as Venezuela, Columbia, Suriname and numerous other islands in the Caribbean. Altogether he made nine, often extended, 


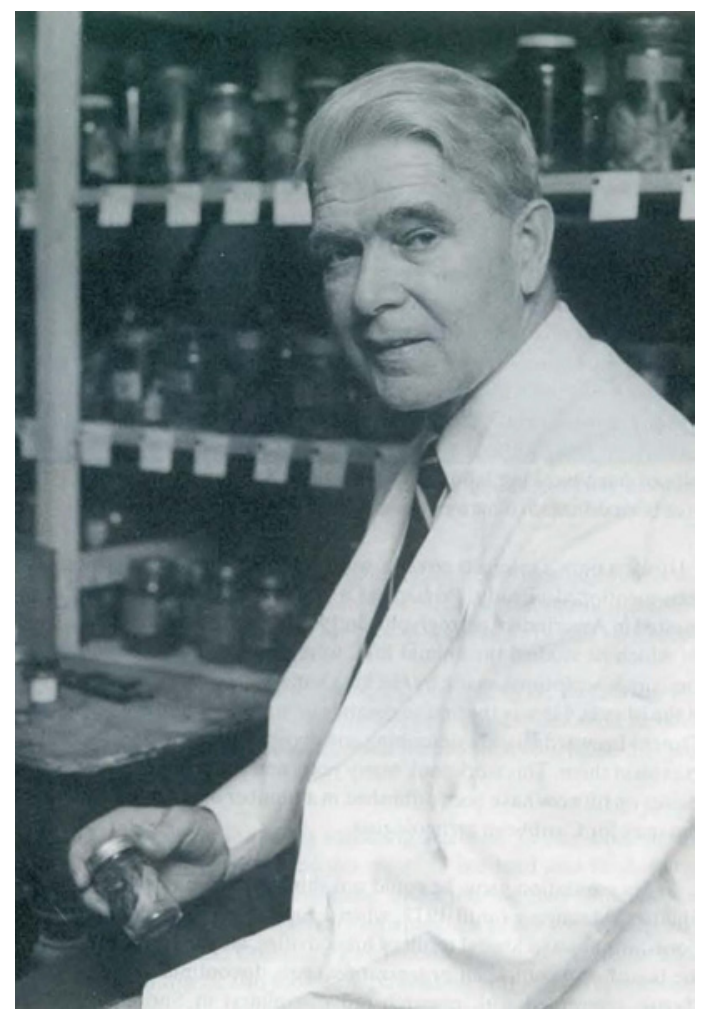

Figure 31. Wagenaar Hummelinck nearly one week after his retirement in January 1972. Photo: Jac. P. Stolp, University Museum, Utrecht.

trips to the area. Wagenaar Hummelinck published a comprehensive catalogue of all his collection sites (Wagenaar Hummelinck 1981). His interests covered a wide field including zoology, archaeology and geology. As far as beetles are concerned, he studied the Caribbean tiger beetles (Wagenaar Hummelinck 1955, 1983).

Among his many other activities, Wagenaar Hummelinck was involved in the foundation of the "Natuurwetenschappelijke Studiekring voor Suriname en de Nederlandse Antillen" (Foundation for Scientific Research in Surinam and the Netherlands Antilles), the "Natuurwetenschappelijke Werkgroep Nederlandse Antillen" (Natural Science Study Group of the Netherlands Antilles) and the "Caraïbisch Marien-Biologisch Instituut" (Caribbean Marine Biological Institute; CARMABI). From 1953 until 1988 he was also (managing) editor of "Studies on the Fauna of Curaçao and other Caribbean Islands" and between 1946 and 1986 of currently one of the longest running scholarly journals on the Caribbean: "(Nieuwe) West-Indische Gids" [(New) WestIndian Guide] (van der Steen 1988, Debrot \& Bak 2019).
In their review of entomological research in the Netherlands Antilles Geijskes \& Wagenaar Hummelinck (1951) stated that "... all the material is at the Amsterdam and Leiden Musea and the results will, in due course, be published in Studies on the fauna of Curaçao....". However, at present still only a very small part of his extensive collection (now largely in the RMNH), has been studied. Parts of his beetles are also housed in AMNH, BMNH, DMAG, HEC, RBINS, SDEI, USNM, UWIC, ZMHB, ZMUC, Michael Ivie's private collection and probably others.

Winkelman, Jaap K. (JKW) (Fig. 32)

Dutch biology teacher and Chrysomelinae expert. Winkelman visited Bonaire in July 2017. He did not collect any Chrysomelinae. Bonairean Chrysomelidae of other subfamilies were identified by, and deposited in the private collection of Ron Beenen. Beetles from other families were identified by, and are in the private collection of, the first author.

\section{Ypenburg, van (Y)}

Listed as a collector of longhorn beetles on Curaçao by Gilmour (1968). We have not been able to find any additional information. Part of the collection of RMNH.

\section{Zijl, J. van (JZ)}

Member of the Natural Sciences Study Group Netherlands Antilles. Collected all kinds of natural history specimens in Aruba during the second half of the 1940s. Collection in RMNH (Wagenaar Hummelinck 1951, Gilmour 1968).

\section{Systematic catalogue of the Coleoptera of the Dutch Antilles}

Order COLEOPTERA Linnaeus, 1758: 345

Suborder ADEPHAGA Clairville, 1806: 2

Family CARABIDAE Latreille, 1802: 80

Subfamily CARABINAE Latreille, 1802: 80

Calosoma alternans (Fabricius, 1792b): 146

[Aruba]

Photo sent by Gerard van Buurt

\section{Curaçao}

Calosoma granulatum: Breuning 1927: 196 - "Brasilien:

Curaçao" (without further data)

\section{St. Martin}

Calosoma alternans: Lemaire 2017: 55 - Grande Anse, EP 


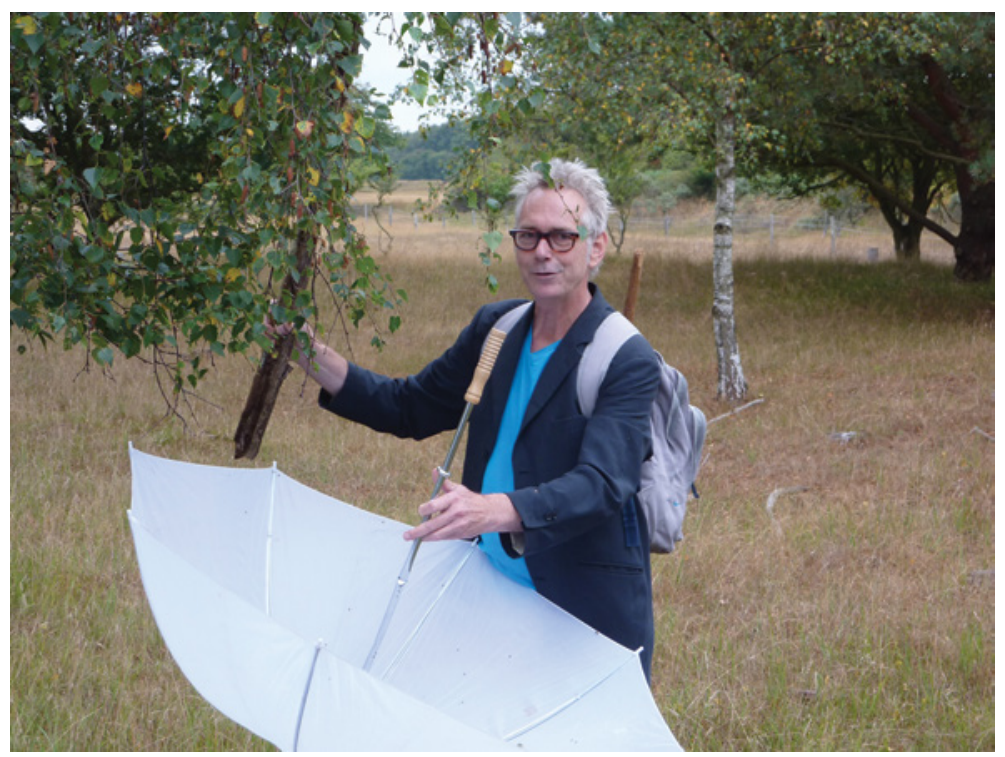

Figure 32. Jaap Winkelman. Photo: Gert van Ee.

Breuning (1927) listed a specimen in the collection of the Zoologische Museum Hamburg from "Brasilien: Curaçao". A place called Curaçao in Brazil could not been found in any gazetteer and is here considered a typographic error. A widespread species which is also present on the northern coast of Venezuela and the island Isla Margarita (Gidaspow 1963), areas that both lie near Curaçao. Gerard van Buurt recently sent a photo of this species taken by Facundo Franken on Aruba.

Leng \& Mutchler (1917), followed by Blackwelder (1944a: 20), listed this species for Barbuda based on a record in the West Indian Bulletin (probably Ballou 1912: 457). Without clarification it was not listed by Peck $(2011,2016)$ although he did so earlier in his Barbados checklist (Peck 2009a). The record in Leng \& Mutchler (1917) was probably erroneous because Ballou recorded this species from Bermuda (and not Barbuda) and St. Vincent.

Subfamily CICINDELINAE Latreille, 1802: 77

\section{Brasiella argentata (Fabricius, 1801b): 242}

\section{Curaçao}

Cicindela argentata: Wagenaar Hummelinck 1983: 85 Emmastad, RHC; Rio Canario, BJ

Wagenaar Hummelinck (1983) wrote that the specimens from Curaçao resemble the subspecies Cicindela argentata pallipes Fleutiaux \& Sallé, 1890: 359 .
Cicindela trifasciata Fabricius, 1781: 286

\section{St. Martin}

Cicindela trifasciata: Horn 1926: 305 - without further data

Cicindela trifasciata: Jonge Poerink 1953: 129 - no locality, JEF; shore of Great Bay, E of Philipsburg, PWH; Atwell's Pond, PWH; Saline de Grande Case, PWH; E. shore of Great Saltpond, PWH

Cicindelidia trifasciata: Balazuc \& Chalumeau 1978: 20

- Baie de Friar, FC; Quartier d'Orléans, FC

Cicindela trifasciata: Wagenaar Hummelinck 1983: 74 - Simpson Bay flat, PWH; Atwell's Pond, PWH; Lowlands, RHC; Great Bay, PWH; Great Saltpond NE, PWH; Oyster Pond, PWH; Flamingo Pond, PWH; Baie aux Cailles, PWH; Saline de Grand Case, $\mathrm{PWH}$

Cicindela (Cicindelidia) trifasciata: Freitag 1992: 155 Atwell's Pond no leg.; Great Saltpond no leg.

Wagenaar Hummelinck (1983) listed a specimen from St. Kitts, an island not listed in Peck (2011, 2016).

Cylindera suturalis (Fabricius, 1798): 62

Curaçao

Cicindela suturalis hebraea: Wagenaar Hummelinck 1983: 79 - Emmastad, RHC; golf links, RHC

\section{St. Martin}

Cicindela suturalis: Horn 1926: 305 - without further data

Cicindela suturalis: Jonge Poerink 1953: 133 - no locality data, HER 
Habroscelimorpha auraria (Klug, 1834a): 27 Aruba

Cicindela auraria: Jonge Poerink 1953: 122 - Saltpan W of Oranjestad, HJMG; Tibushi, PWH; Salinja Master, W of Savaneta, PWH; Salinja San Jose, N of Palm Beach, PWH

Cicindela auraria: Wagenaar Hummelinck 1983: 71 Spaans Lagoen, RHC; Salinja Balashi near Spaans Lagoen, PWH

Cicindela (Habroscelimorpha) auraria: Freitag 1992: 156 - without further data

\section{Bonaire}

Cicindela auraria: Jonge Poerink 1953: 122 - Klein Bonaire, N. shore of Salinja, PWH; Salinja Plenchi, PWH; Blauwe Pan, ACJB

Cicindela auraria: Wagenaar Hummelinck 1983: 71 Lagoen, PWH; Blauwe Pan, PWH; Klein Bonaire, Salinja Abau, PWH; Salinja Martinus, PWH; Awa Lodo di Lac, PWH; Salinja di Cai, PWH; Witte Pan, PWH; Isla di Pedro, Lac, PWH; Casdi Meeuchi, Lac, PWH Cicindela (Habroscelimorpha) auraria: Freitag 1992: 156 - Saint Marinus, no leg.

\section{Curaçao}

Cicindela auraria: Neervoort van de Poll 1886: 227 Plantation Hermanus, NVDP

Cicindela auraria: Horn 1926: 304 - without further data Cicindela auraria: Jonge Poerink 1953: 122 - Hotel Piscadera Baai, PWH; Salinja Groot Santa Marta, PWH; Otrabanda, Willemstad, BJ

Cicindela auraria: Wagenaar Hummelinck 1983: 71 Salinja St. Martha, PWH; St. Jorisbaai, PWH; Salinja St. Kruis, PWH

Tetracha gracilis (Reiche, 1842): 240

\section{Aruba}

Tetracha (Neotetracha) gracilis: Naviaux 2007: 134 without further data

\section{Curaçao}

Tetracha curacaoica: Neervoort van de Poll 1886: 225 Plantation Brievengat, NVDP

Megacephala affinis gracilis: Horn 1926: 76 - without further data

Megacephala (Tetracha) affinis gracilis: Wagenaar Hummelinck 1955: 95 - Plantation Brievengat, NVDP; Hato, PWH

Tetracha (Neotetracha) gracilis curacaoica: Naviaux 2007: 134 - Brievengat, NVDP

Tetracha sobrina (Dejean, 1831): 202

Aruba

Megacephala sobrina forma bonaireana: Wagenaar Hummelinck, 1955: 110 - Savaneta, BJ

Megacephala sobrina forma bonaireana: Wagenaar Hummelinck 1983: 109 - Salinja Master, PWH; Rooi Bringamosa, PWH
Tetracha sobrina: Naviaux 2007: 50 - without further data

\section{Bonaire}

Tetracha sobrina: Werner 1925: 555 - no locality, AG Megacephala sobrina forma bonaireana: Wagenaar Hummelinck, 1955: 110 - Salinja Tarn, PWH; Kralendijk, PWH; Deenterra, Tanki George, PWH; Klein Bonaire, Salinja, PWH; Goto, PWH; Cay, PWH; Salinja Martinus, PWH

Megacephala sobrina forma bonaireana: Wagenaar Hummelinck 1983: 109 - Pos Frances, PWH; Goto, RHC; Klein Bonaire, Pos Calbas, PWH; Dos Pos, PWH; Kralendijk, PWH

Tetracha sobrina sobrina: Naviaux 2007: 50 - without further data

\section{Curaçao}

Tetracha sobrina: Neervoort van de Poll 1886: 226 Gouverneur Hotel, Willemstad, Madame van den Brandhof

Tetracha sobrina: Horn 1925: 133 - same as above Megacephala sobrina confusa: Horn 1926: 75 - without further data

Megacephala sobrina sobrina forma bonaireana: Wagenaar Hummelinck, 1955: 110 - Plantersrust, GJHM; Groot St. Joris, PWH; Groot St. Martha, PWH; SE of Pos Grandi, PWH; Plaja Djerimi, BJ

Megacephala sobrina sobrina forma bonaireana: Wagenaar Hummelinck 1983: 109 - Boca Labadera, PWH

Tetracha sobrina sobrina: Naviaux 2007: 50 - without further data

\section{St. Martin}

Megacephala sobrina infuscata: Horn 1926: 75 - without further data

Megacephala sobrina sobrina forma antiguana: Wagenaar Hummelinck 1955: 108 - “S. Mt. Rma”, ex coll. Horn; Great Saltpond, PWH

Megacephala (Tetracha) sobrina race infuscata: Balazuc \& Chalumeau 1978: 18 - Tintamarre, P. Pinchon; Baie de Friar, FC; Quartier d'Orléans, FC Megacephala sobrina sobrina forma antiguana: Wagenaar Hummelinck 1983: 109 - Point Blanche, PWH; Great Saltpond, PWH; Oyster Pond, PWH; Cul-de-Sac, FC Wagenaar Hummelinck (1983) listed a specimen from St. Kitts, an island not listed in Peck (2011, 2016).

Subfamily SCARITINAE Bonelli, 1810: Tabula synoptica

\section{Paraclivina fasciata (Putzeys, 1846a): 106}

Saba

Clivina (Paraclivina) fasciata: Peck 2016: 36 - without further data

Peck (2016) listed the page number of the original description as 624. This is the page number 
of the paper in the Mémoires de la Société Royale des Sciences de Liége (Putzeys 1846b). Bousquet (2012, 2016) presented evidence that, although listed as a reprint, the separate publication was published earlier.

Paraclivina tristis (Putzeys, 1846a): 102

\section{Bonaire}

Clivina (Paraclivina) tristis: Nichols 1988: 94 - Dos Poos, no leg.

\section{Curaçao}

Clivina (Paraclivina) tristis: Nichols 1988: 94 - without further data

Peck (2016) listed the page number of the original description as 620. This is the page number of the paper in the Mémoires de la Société Royale des Sciences de Liége (Putzeys 1846b). Bousquet (2012, 2016) presented evidence that, although listed as a reprint, the separate publication was published earlier.

Subfamily HARPALINAE Bonelli, 1810: Tabula synoptica

\section{Apenes variegata (Dejean, 1825): 217}

\section{St. Eustatius}

Apenes variegata: Ball \& Shpeley 2009: 104 - no locality, STD

Apenes pallipes: UPRM 2020: GBIF - no locality, STD

\section{St. Martin}

Apenes variegata: Ball \& Shpeley 2009: 104 - Grand Case, no leg.

\section{Athrostictus paganus (Dejean, 1831): 834}

\section{St. Eustatius}

Athrostictus paganus: Shpeley et al. 2017: 24 - no locality, STD

Athrostictus paganus: UPRM 2020: GBIF - no locality, STD

Athrostictus paganus: This study - Boven National Park, AJW

\section{St. Martin}

Athrostictus paganus: Shpeley et al. 2017: 24 - Great Bay, STD; Marigot, FC

Peck (2016) listed this species twice in two genera with different ranges: Athrostictus paganus and Selenophorus paganus. The range of this species in the Antilles should be Antigua, Barbados, Barbuda, Canouan, Grenada, Guadeloupe, Martinique, Mayreau, Montserrat, Mustique, Nevis, St. Croix, St. Eustatius, St. Kitts, St. Lucia, St. Martin, St. Vincent, Tobago and Union (Peck 2016, Shpeley et al. 2017, UPRM 2020).
Eucheila boyeri (Solier, 1835a): 111

\section{Aruba}

Eucheila (Inna) boyeri: Shpeley \& Ball 2000: 162 - no locality, $\mathrm{PWH}$

Galerita americana (Linnaeus, 1758): 415

\section{St. Martin}

Galerita americana: Reichardt 1967: 63 - without further data

Neoaulacoryssus cupripennis (Gory, 1833): 239 Dutch Antilles

Neoaulacoryssus cupripennis: Ball 1992: 85 - windward Antilles

Neoaulacoryssus cupripennis: Shpeley et al. 2017: 18 Dutch Antilles

\section{Aruba}

Neoaulacoryssus cupripennis: This study - Station 270 [= top Jamanota], PWH

Ball (1992) and Shpeley et al. (2017) did not mention a specific island in the Dutch Antilles but the collection of RMNH holds a specimen from Aruba which was part of a loan to Ball and Shpeley.

\section{Pentagonica flavipes (LeConte, 1853a): 377}

Saba

Pentagonica flavipes: Peck 2016: 40 - without further data

\section{St. Eustatius}

Pentagonica flavipes: This study - The Quill, EOC, MK \& AJW; crater rim The Quill, EOC, MK \& AJW New species record for St. Eustatius. Sieved from leaf litter.

\section{Selenophorus alternans Dejean, 1829: 86}

Saba

Selenophorus alternans: Shpeley et al. 2017:176 - Mountain Road, MPTG

Shpeley et al. (2017: 175) added Anguilla, Nevis and Redonda to the range as published by Peck (2011, 2016).

\section{Selenophorus discopunctatus Dejean, 1829: 92}

\section{Saba}

Selenophorus discopunctatus: Shpeley et al. 2017: 150 Spring Bay Trail, DSS; The Bottom, MPTG

\section{St. Eustatius}

Selenophorus discopunctatus: Shpeley et al. 2017: 150 no locality, STD; Oranjestad, PWH

Selenophorus discopunctatus: UPRM 2020: GBIF Oranjestad, STD

Selenophorus discopunctatus: This study - Boven National Park, AJW

St. Martin 
Selenophorus discopunctatus: Shpeley et al. 2017: 150

- Great Bay, STD; Baie de Friar, FC; Marigot, FC; Galion, FC

Shpeley et al. (2017: 148, 150) added Anguilla, Barbuda and Redonda to the range as published by Peck $(2011,2016)$.

\section{Selenophorus flavilabris Dejean, 1829: 79 \\ St. Martin}

Selenophorus flavilabris: Shpeley et al. 2017: 164 Simpson's Bay STD; Old Battery Hill, E of Great Bay, PWH; Cul de sac, FC; Pic Paradis, FC

Dejean (1829) recorded the type locality as "île Saint -Barthélémy" but Peck (2011) did not list the species. Peck (2016) recorded it from Bahamas, Puerto Rico and "unspecified Leeward Islands". Shpeley et al. (2017: 85-86), although listing the type locality as "Saint Barthélemy, Leeward Islands, Lesser Antilles" recorded the geographical distribution of the nominal subspecies as "only from Puerto Rico and the two Lesser Antillean islands of Anguilla and St. Martin". Saint-Barthélemy should be added to the range.

\section{Selenophorus integer (Fabricius, 1801b): 196} Saba

Selenophorus integer: Shpeley et al. 2017: 168 - Windward Side, RSM; Mountain Road, MPTG; St. John's, $\mathrm{MB}$

\section{St. Eustatius}

Selenophorus integer: Shpeley et al. 2017: 168 - Oranjestad, PWH

Selenophorus integer: This study - Oranjestad, AJW

\section{St. Martin}

Selenophorus integer: Shpeley et al. 2017: 168 - Simpson's Bay, STD; Great Bay, STD; St. Peter, Cul-de-Sac, PWH

Shpeley et al. (2017: 167) added Anguilla and Barbuda to the range as published by Peck (2011, 2016).

\section{Selenophorus parumpunctatus Dejean, 1829: 104}

\section{Saba}

Selenophorus parumpunctatus: Peck 2016: 40 - without further data

Selenophorus parumpunctatus: Shpeley et al. 2017:186

- Windwardside, RSM; Windwardside, RMB \& HBV;

Spring Bay Trail, DSS; Cove Bay, Tide Pools Trail, MAI;

Mountain Road, MPTG; Bottom, MPTG

\section{St. Eustatius}

Selenophorus parumpunctatus: Shpeley et al. 2017:186 Venus Bay, MAI \& N. Esteban

\section{St. Martin}

Selenophorus parumpunctatus: Shpeley et al. 2017:186

- Pt. Blanche Bay, PWH; N of Pt. Blancha, PWH;
Baie de Friar, FC; Cul de sac, FC; Pic Paradis, FC

Carabus sinuatus Gyllenhal, 1806: 203 is a primary junior homonym of Carabus sinuatus Gmelin, 1790 and synonymous with Selenophorus parumpunctatus (Bousquet 2012). Although the types of sinuatus were reported to come from "America Insulis" by Gyllenhal, Dejean (1829: 106) noted that Schönherr sent specimens to him as originating from St. Barthélemy, an island not listed in Peck $(2011,2016)$. Bousquet (2012) stated that the whereabouts of the types are unknown and that they are probably in UUZM. Bousquet proves to be right. The four syntypes are listed in GBIF (Telenius \& Shah 2016). Shpeley et al. (2017: 185) further added Anguilla, St. Kitts, Nevis and Barbuda to the range as published by Peck $(2011,2016)$.

Selenophorus propinquus Putzeys, 1874: 118

Saba

Selenophorus propinquus: Shpeley et al. 2017: 173 Dancing Place Trail, MAI; Dancing Place Trailhead, JAS

\section{St. Eustatius}

Selenophorus propinquus: This study - Boven National Park, EOC, MK \& AJW

\section{St. Martin}

Selenophorus propinquus: Shpeley et al. 2017: 173 - Pic Paradis, FC

New species record for St. Eustatius. A single female sieved from leaf litter. Shpeley et al. (2017: 172) added Anguilla and St. Barthélemy to the range as published by Peck (2011, 2016).

\section{Selenophorus subquadratus Putzeys, 1878: 293}

\section{Saba}

Selenophorus subquadratus: Shpeley et al. 2017: 155 Mountain Road, MPTG

Shpeley et al. (2017: 155) added St. Barthélemy and St. Kitts to the range as published by Peck (2011, 2016).

Selenophorus woodruffi Ball \& Shpeley, 1992: 96

Aruba

Selenophorus woodruff: Ball \& Shpeley, 1992: 96 - San Nicolaas, JGB

\section{Curaçao}

Selenophorus woodruff: Ball \& Shpeley, 1992: 96 - Cas Cora, PWH; Agricultural Station, PWH; Jongbloed, BJ

\section{Stenomorphus angustatus Dejean, 1831: 696}

\section{Curaçao}

Stenomorphus angustatus angustatus: Ball et al. 1991: 954 - Mahaai, no leg.; Jongbloed, no leg. 
Family GYRINIDAE Latreille, 1810: 168

Subfamily GYRININAE Latreille, 1810: 168

Dineutus americanus (Linnaeus, 1767): 568 Curaçao

Dineutus (Cyclinus) americanus: Ochs 1963: 124 - Piscadera Baai, RHC; Santa Martha, RHC

For usage of Dineutus MacLeay, 1825 rather than Dineutes, see Gustafson and Miller (2013).

Gyrinus ovatus Aubé, 1838: 708

Curaçao

Gyrinus (Neogyrinus) racenisi: Ochs 1963: 123 - Piscadera Baai, RHC; Santa Martha, RHC

Gustafson \& Short (2017) recently synonymised Gyrinus racenisi with $G$. ovatus.

Family HALIPLIDAE Aubé, 1836: 15

Haliplus gravidus Aubé, 1838: 26

Bonaire

Haliplus gravidus: van Vondel \& Spangler 2008: 94 - Onima, PWH; Pos Baca Grandi, PWH

Curaçao

Haliplus gravidus: van Vondel \& Spangler 2008: $94-$ Santa Martha, RHC; Tanki di Terra Corá, PWH

St. Martin

Haliplus gravidus: van Vondel \& Spangler 2008: 94 Bloomendale Cistern, PWH

Family NOTERIDAE Thomson, 1860: 34

Hydrocanthus debilis Sharp, 1882: 281

\section{Aruba}

Hydrocanthus debilis: Higler \& van Halewijn 1991: 2166 - lake Bubali, no leg.

Details about collection dates for all lake Bubali records can be found in the more extensive report (van Halewijn et al. 1992).

Suphis cimicoides Aubé, 1837a: 209

\section{Aruba}

Suphis cimicoides: Higler \& van Halewijn 1991: 2166 lake Bubali, no leg.

For the year of publication see Bousquet (2016).

Suphisellus nigrinus (Aubé, 1838): 411

Aruba

Suphisellus nigrinus: Higler \& van Halewijn 1991: 2166

- lake Bubali, no leg.

Family DYTISCIDAE Leach, 1815: 84

Subfamily COPELATINAE Branden, 1885: 82
Copelatus caelatipennis Aubé, 1838: 382

Aruba

Copelatus caelatipennis: Higler \& van Halewijn 1991: 2166 - lake Bubali, no leg.

Subfamily HYDROPORINAE Aubé, 1836: 14

Celina Aubé, 1837a

Aruba

Celina species: Higler \& van Halewijn 1991: 2166 lake Bubali, no leg.

Saba

Celina species: Bass 2008: 35 - Sandy Cruz Trail Pool, DBA

Pachydrus globosus (Aubé, 1838): 457

Aruba

Pachydrus globosus: Higler \& van Halewijn 1991: 2166

- lake Bubali, no leg.

Subfamily DYTISCINAE Leach, 1815: 84

Megadytes laevigatus (Olivier, 1791a): 308

Aruba

Megadytes laevigatus: Higler \& van Halewijn 1991:

2166 - lake Bubali, no leg.

This species is usually attributed to Olivier (1795)

but Olivier (1791a) provides the same description. This was recently corrected in the on-line Dytiscidae catalogue by Nilsson \& Hájek (2018).

Thermonectus circumscriptus (Latreille, 1809): 223

\section{St. Eustatius}

Thermonectus circumscriptus: This study - Zeelandia Bay, KB

New species record for St. Eustatius. A single female collected from an abandoned swimming pool. Identified by Rafael Braga who studied this genus and presented a very useful poster to identify Thermonectus Dejean, 1833 females at the Annual Meeting of the Southwestern Branch of the Entomological Society of America, 2013, Las Cruces, New Mexico (Braga et al. 2013).

Suborder POLYPHAGA Emery, 1886: 654

Family HYDROPHILIDAE Latreille, 1802: 136

Ivie et al. (2009) presented a poster with a preliminary number of species per family found on Saba. It contained seven species of this family from Saba. The present paper contains information on four which means that at least three, as yet unpublished, other species are present on the island. 
Subfamily HYDROPHILINAE Latreille, 1802: 136

Berosus Leach, 1817: 92

Aruba

Berosus species: Higler \& van Halewijn 1991: 2166 lake Bubali, no leg.

Enochrus sharpi Gundersen, 1977: 262

Aruba

Enochrus sharpi: Higler \& van Halewijn 1991: 2166 lake Bubali, no leg.

Hydrophilus insularis Laporte, 1840: 50

Aruba

Hydrophilus insularis: Higler \& van Halewijn 1991: 2166 - lake Bubali, no leg.

\section{Bonaire}

Hydrous insularis: Werner 1925: 555 - no locality, AG

\section{St. Eustatius}

Hydrophilus insularis: This study - Venus Bay, KB

New species record for St. Eustatius. Identified by Oscar Vorst and the first author. Collected from an artificial pond.

Laccobius Erichson, 1837: 202

Saba

Laccobius species: Bass 2008: 35 - Sandy Cruz Trail Pool, DBA

Tropisternus collaris (Fabricius, 1775): 229

\section{Aruba}

Tropisternus collaris: Higler \& van Halewijn 1991: 2166

- lake Bubali, no leg.

Tropisternus lateralis (Fabricius, 1775): 228

Aruba

Tropisternus lateralis: Higler \& van Halewijn 1991:

2166 - lake Bubali, no leg.

Saba

Tropisternus lateralis: Bass 2008: 35 - Lynn Pond, Windward Side, DBA

\section{St. Eustatius}

Tropisternus lateralis: This study - Zeelandia Bay, KB

[St. Martin]

Tropisternus lateralis: Yokoyama 2013: 85 - without further data

New species record for St. Eustatius. Identified by Oscar Vorst and the first author. Three specimens collected from the same abandoned pool as Thermonectus circumscriptus. Listed and photographed by Yokoyama (2013) and shown as present with reference to Yokoyama on the website of the French l'Inventaire National du Patrimoine Naturel (INPN 2020) for St. Martin. It is not clear if vouchers are available.
Subfamily SPHAERIDIINAE Latreille, 1802: 135

Cercyon nigriceps (Marsham,1802): 72

Saba

Cercyon (Cercyon) nigriceps: Peck 2016: 51 - without further data

Introduced.

Oosternum sharpi Hansen, 1999: 242

Saba

Oosternum sharpi: Deler-Hernández et al. 2014: 57 [Windwardside], DSS \& MAI

Location based on the published geographic coordinates. Not listed by Peck (2016).

Phaenonotum exstriatum (Say, 1835): 171

\section{Aruba}

Phaenonotum exstriatum: van Halewijn et al. 1992: table 5 - lake Bubali, no leg.

Family HISTERIDAE Gyllenhal, 1808d: 74

Ivie et al. (2009) listed six species of this family from Saba. Peck (2016) listed two which means that at least five, as yet unpublished, other species are present on the island.

Subfamily ABRAEINAE MacLeay, 1819: 25

Aeletes Horn, 1873a: 356

Saba

Aeletes species Peck 2016: 52 - without further data

Halacritus blackwelderi Wenzel, 1944: 63

\section{St. Eustatius}

Halacritus blackwelderi: This study - Concordia Bay, EOC

New species record for St. Eustatius. Collected from under washed-up algae. Wenzel (1944) mentioned a specimen collected by Blackwelder on St. Kitts which may be this species but differs in several respects from the types from Antigua.

Subfamily HISTERINAE Gyllenhal, 1808d: 74

Hister servus Erichson, 1834: 147

Saba

Hister servus: Peck 2016: 54 - without further data

Subfamily SAPRININAE Blanchard, 1845

Hypocaccus brasiliensis (Paykull, 1811): 66

\section{St. Eustatius}

Hypocaccus brasiliensis: This study - Concordia Bay, JB; Concordia Bay, EOC

New species record for St. Eustatius and the northern Lesser Antilles. Although not recorded 
before, probably widespread in the area. Collected from under washed-up algae, a habitat that does not often seem to have been sampled in the Antilles.

\section{Xerosaprinus testudo (Casey, 1916): 267}

\section{St. Eustatius}

Xerosaprinus testudo: Grant \& Turcatel 2020: GBIF Oranjestad, BM

\section{St. Martin}

Xerosaprinus testudo: Grant \& Turcatel 2020: GBIF Philipsburg, BM

\section{Curaçao}

Xerosaprinus testudo: Grant \& Turcatel 2020: GBIF without further details

The above are all new island records. The FMNHdataset in GBIF (Grant \& Turcatel 2020) and SCAN (2020) erroneously list St. Eustatius as part of St. Martin and the St. Eustatius records are shown on the map of the southern part of St. Martin. The locality reads "Sint Eustatius, Oranjestad" though.

Xerosaprinus viator (Marseul, 1855): 499 Curaçao

Xerosaprinus viator: Mazur 2011: 194 - without further details

Family PTILIIDAE Erichson, 1845: 15

Ivie et al. (2009) listed five, as yet unpublished, species of this family from Saba.

Family LEIODIDAE Fleming, 1821: 51

Subfamily LEIODINAE Fleming, 1821: 51

\section{Zeadolopus antiguensis Peck \& Cook 2014: 22} Saba

Zeadolopus antiguensis Peck \& Cook 2014: 22 - Bud's Mountain Trail, DSS, JAS \& J.F. Johnson; Bud's Mountain Trail, DSS \& MAI; Bud's Mountain Trail, DSS et al.; Ecolodge on Mount Scenery, DSS \& JAS; Scout's Place Hotel, DSS

Family SCYDMAENIDAE Leach, 1815: 92

Subfamily SCYDMAENINAE Leach, 1815: 92

Euconnus satishanandi Makhan, 1997: 136 Curaçao

Euconnus satishanandi Makhan, 1997: 136 - Rooi Cajoeda, Knip, PWH

Euconnus Thomson, 1859: 61

Saba

Euconnus species: Peck 2016: 57 - without further data
Listed erroneously as Euconnus gouadeloupensis by Bos et al. (2018) possibly based on Peck (2016) who listed it under this species but clearly as unidentified material of the genus.

Family STAPHYLINIDAE Latreille, 1802: 124

Ivie et al. (2009) listed 54, as yet unpublished, species of this family from Saba.

Subfamily PSELAPHINAE Latreille, 1802: 239

Eupsenius politus Reitter, 1883: 36

\section{St. Eustatius}

Eupsenius politus: This study - The Quill, EOC, MK \& AJW; crater rim The Quill, EOC, MK \& AJW

New species record for St. Eustatius. Sieved from leaf litter.

Subfamily ALEOCHARINAE Fleming, 1821: 49

Diestota sperata Sharp, 1876: 47

St. Martin

Atheta sperata: Fauvel 1891: 124 - without further data Not listed for St. Martin by Peck (2011, 2016). Besides Brazil, Cuba, Guadeloupe, Guatemala, Haiti, Mexico, Panama and Venezuela, Fauvel (1891) also listed "Saint Martin" without any further data. This material was probably in his own collection and currently in the Institut royal des Sciences naturelles de Belgique.

Subfamily OSORIINAE Erichson, 1839: 30

Molosoma Say, 1831: 48

St. Eustatius

Molosoma species: This study - The Quill, EOC, MK \& AJW

New genus record for St. Eustatius. A single female sieved from leaf litter. This genus was treated as Osorius Guérin, 1829: pl. 9 by Peck (2011, 2016) and Osoriellus Fagel, 1959: 186 by Irmler (2014). Irmler (2016) later synonymised Osoriellus with Molosoma.

Subfamily MEGALOPSIDIINAE Leng, 1920: 98

Megalopinus punctatus (Erichson, 1840): 752 Curaçao

Megalops punctatus: Fauvel 1901: 74 - no locality, EFB

A single specimen. Puthz (2012) recently revised Megalopinus Eichelbaum, 1915 and described a series of new species. However, he did not investigate any specimens from Curaçao. 
Subfamily PAEDERINAE Fleming, 1821: 49

Sciocharis exilis (Erichson, 1840): 627

\section{St. Eustatius}

Sciocharis exilis: This study - The Quill, EOC, MK \& AJW

New species record for St. Eustatius. Sieved from leaf litter.

Subfamily STAPHYLININAE Latreille, 1802: 124

Cafius bistriatus (Erichson, 1840): 502

\section{St. Eustatius}

Cafius bistriatus: This study - Concordia Bay, EOC

New species record for St. Eustatius. Collected from sandy beach under algae.

Family PASSALIDAE Leach, 1815: 100

Ivie et al. (2009) listed one, as yet unpublished, species of this family from Saba.

Family TROGIDAE MacLeay, 1819: 59

\section{Omorgus suberosus (Fabricius, 1775): 31}

\section{Bonaire}

Trox species: Werner 1925: 556: no locality, AG

Omorgus suberosus: This study - Rincón, JKW

\section{Saba}

Omorgus suberosus: Peck 2016: 81 - without further data

\section{St. Eustatius}

Omorgus suberosus: This study - Oranjestad, EOC

\section{St. Martin}

Trox suberosus: Chalumeau \& Gruner 1974: 788 -

Koolbaai, FC

New species record for St. Eustatius. Several specimens were collected from a dead cow and at light. Jaap Winkelman's specimen on Bonaire was caught with a light trap. Werner's (1925) "Trox species" is probably this species. Vaurie (1962: 144) listed this species for St. Barthélemy, an island not listed by Peck $(2011,2016)$.

Family HYBOSORIDAE Erichson, 1847: 717

Subfamily HYBOSORINAE Erichson, 1847: 717

\section{Hybosorus illigeri Reiche, 1853: 88}

\section{St. Eustatius}

Hybosorus illigeri: This study - Zeelandia, EOC; Oranjestad, EOC

New species record for the Lesser Antilles. Collected from bovine dung near the beach at Zeelandia and from inside a light fixture in Oranjestad. Introduced, native to southern Europe.
Hitherto known in the Antilles from Jamaica (Howden 1970), the Bahamas and Cuba (Kuijten 1983), and the Dominican Republic (Ocampo 2002). Ballerio et al. (2018) recently petitioned the ICZN to conserve the name Hybosorus illigeri by giving it precedence over several very rarely used senior synonyms.

Family SCARABAEIDAE Latreille, 1802: 144

Ivie et al. (2009) listed eight species of this family from Saba. The present paper contains information on seven which means that at least one, as yet unpublished, other species is present on the island.

Subfamily APHODIINAE Leach, 1815: 97

Labarrus lividus (Olivier, 1789a): 86

Saba

Labarrus lividus: Peck 2016: 83 - without further data Introduced.

Nialaphodius nigrita (Fabricius, 1801b): 73

Saba

Nialaphodius nigrita: Peck 2016: 83 - without further data

St. Eustatius

Aphodius cuniculus: UPRM 2020: GBIF - no locality, STD

Nialaphodius nigrita: This study - Botanical Garden, $\mathrm{KB}$

Introduced. New species record for St. Eustatius. The one from this study collected at light.

Ataenius complicatus Harold, 1869: 102 Curaçao

Ataenius complicatus: Stebnicka 2006: 94 - Hato, BM

Ataenius gracilis (Melsheimer, 1845): 137

Saba

Ataenius gracilis: Peck 2016: 85 - without further data

Ataenius scutellaris Harold, 1867a: 82

Saba

Ataenius scutellaris: Peck 2016: 86 - without further data

\section{St. Martin}

Ataenius scutellaris: Chalumeau \& Gruner 1974: 803 Koolbaai, FC

Ataenius strigicaudus Bates, 1887: 96

\section{St. Eustatius}

Ataenius cf. strigicaudus: This study - crater rim The Quill, EOC, MK \& AJW

New provisional species record for St. Eustatius. A single female specimen sieved from leaf litter. As 
far as we are aware, Peck (2016) was the first to list Montserrat but he did so without the asterisk used in his paper for new island records.

Psammodius viti Chalumeau, 1983b: 83

\section{St. Eustatius}

Psammodius sp. aff. viti: This study - Concordia Bay, EOC

New genus record for St. Eustatius. A single specimen collected from a sandy beach under algae. Psammodius viti is only known from Les Saintes (Rakovič 1990, Gordon \& Pittino 1992).

\section{Subfamily CETONIINAE Leach, 1815: 99}

Cotinis Burmeister, 1842: 254

\section{Aruba}

Cotinis species: This study - no locality, C.E. Fun New genus record for Aruba. A female that keyed out as Cotinis mutabilis (Gory \& Percheron, 1834: 70) in the key of Gasca-Álvarez \& Deloya (2015). However, it did not completely match the species' description. A search through the RMNH collection revealed 14 other specimens from Aruba but none from the other southern Dutch Antilles. The dissected aedeagus of a male specimen did not match that of $C$. mutabilis. Further study is needed to establish the identity of the Aruban Cotinis. For the year of publication of $C$. mutabilis see Bousquet (2016).

Subfamily SCARABAEINAE Latreille, 1802: 144

Digitonthophagus gazella (Fabricius, 1787a): 377 St. Eustatius

Digitonthophagus gazella: This study - Zeelandia, EOC; Oranjestad, EOC

[St. Martin]

Onthophagus gazella: Yokoyama 2013: 83 - without further data

New species record for St. Eustatius. Collected from bovine dung at the beach near Zeelandia, from bovine dung in Oranjestad and at light in Oranjestad. Listed and photographed by Yokoyama (2013) and shown as present with reference to Yokoyama on the website of the INPN (2020) for St. Martin. It is not clear if vouchers are available. As far as we could trace Peck (2010) was the first to list Antigua but it is unclear on which basis.

Introduced, native to Africa. The genus was recently revised by Génier \& Moretto (2017). Their conclusions were that Digitonthophagus gazella comprises a species complex with 14 species and the name of the widely introduced species would be $D$. dorcas (Olivier, 1789a) if the principle of priority is applied (see also Génier \& Davis 2017). To maintain nomenclatural stability an application has been submitted to the International Commission on Zoological Nomenclature to conserve the name Scarabaeus gazella Fabricius, 1787a (Génier \& Krell 2017).

Pseudocanthon Bates, 1887: 35

[Curaçao]

Coleoptera indet.: Benschop 2010: Observation .org - Willemstad, A. Benschop

A photo on the citizen-science website Observation .org shows a Pseudocanthon species that could be P. chlorizans (Bates, 1887): 34, a species otherwise known from the southern Antillean islands Bequia, Carriacou, Grenada, Mayreau, Mustique and Union and mainland Mexico, Belize and El Salvador (Peck 2016).

Subfamily MELOLONTHINAE Leach, 1819a: 189

Phyllophaga sanbarthensis Chalumeau \& Gruner, 1976: 97

\section{St. Martin}

Phyllophaga sanbarthensis Chalumeau \& Gruner, 1976: 97 - Philipsburg, PWH; Old Battery, PWH; Baie de Friar, FC

Phyllophaga sanbarthensis: Chalumeau 1985: 31 - Baie Longue, FC

Phyllophaga stehlei Chalumeau, 1985: 28

\section{St. Martin}

Phyllophaga stehlei Chalumeau, 1985: 28 - Pic Paradis, FC

Endemic to St. Martin.

\section{Subfamily DYNASTINAE MacLeay, 1819: 64}

Chalepides barbatus (Fabricius, 1787b): 10

\section{St. Martin}

Chalepides barbatus: Chalumeau \& Gruner 1977: 590

- Jone's Gut, P. Pinchon; Marigot, P. Pinchon; Cul-deSac, AD; Marigot, FC

Chalepides barbatus: Ratcliffe \& Cave 2015: 73 - Culde-Sac, no leg.; Jones Gut, no leg.; le François, no leg.; Marigot, no leg.; Mullet Bay, no leg.; Quartierd'Orléans, no leg.

Ratcliffe \& Cave (2015: 72) also listed Nevis; Anonymous (1913: 186, as Dyscinetus barbatus), Hutson (1917: 266, as D. barbatus) and Ratcliffe \& Cave (2015: 72), but strangely enough not Moore et al. (2018), added Barbuda to the range as published by Peck (2011, 2016). 
Cyclocephala amazona (Linnaeus, 1767): 551 St. Martin

Cyclocephala amazona Ratcliffe \& Cave 2015: 79 Cul-de-Sac, no leg.; Jones Gut, no leg.; Marigot, no leg.

Ratcliffe \& Cave (2015: 79) added St. Barthélemy to the range of this species as published by Peck (2011, 2016).

\section{Cyclocephala immaculata (Olivier, 1789b): 29}

\section{St. Martin}

Cyclocephala danforthi: Chapin, 1935: 69 - Great Bay, STD

Cyclocephala immaculata: Chalumeau \& Gruner 1977: 582 - Grande Baie, FC

Cyclocephala immaculata: Ratcliffe \& Cave 2015: 92 Great Bay, no leg.

Ratcliffe \& Cave (2015: 91-92) added Nevis, Barbuda and Antigua to the range of this species as published by Peck $(2011,2016)$.

\section{Cyclocephala mafaffa Burmeister, 1847: 69 \\ Saba}

Cyclocephala mafaffa: Gillett \& Gillett 2015: 4 - The Level, MPTG; English Quarter (Windwardside), MPTG; Upper Mountain Road, MPTG; Crispeen, MPTG

Cyclocephala mafaffa grandis: Ratcliffe \& Cave 2015: 98 - Crispeen, no leg.; English Quarter, no leg.; Mountain Road, no leg.; Mount Scenery, no leg.; The Level, no leg.

Moore et al. (2020) recently synonymised the subspecies Cyclocephala mafaffa grandis under $C$. mafaffa.

\section{Phileurus valgus (Olivier, 1789a): 43 \\ [Curaçao]}

Phileurus valgus: Oduber 2019: iNaturalist - Oranjestad, M. Oduber

\section{Saba}

Phileurus valgus antillarum: Gillett \& Gillett 2015: 6 The Level, MPTG; Maskerhorne Hill, MPTG; Mount Scenery, MPTG; Great Hill, MPTG

Phileurus valgus: Ratcliffe \& Cave 2015: 264 - Crispeen, no leg.; Ecolodge, no leg.; Great Hill, no leg.; Maskerhorne Hill, no leg.; Mount Scenery, no leg.; The Level, no leg.

\section{St. Eustatius}

Phileurus valgus: Ratcliffe \& Cave 2015: 264 - The Quill, no leg.

\section{St. Martin}

Phileurus valgus antillarum: Chalumeau \& Gruner 1977: 599 - Koolbaai, FC

Phileurus valgus: Ratcliffe \& Cave 2015: 264 - Koolbaai, no leg.
For a clarification of the authorship of this species see Ratcliffe \& Cave (2015) and Hielkema (2017). The Curaçao record is based on a photo sent to the first author by Gerard van Buurt (Naturalis 2018a). Ratcliffe \& Cave (2015: 263) added Anguilla and St. Kitts to the range of this species as published by Peck $(2011,2016)$.

Strategus aloeus (Linnaeus, 1758): 345

Curaçao

Strategus aloeus aloeus: Endrödi 1976: 136 - without further data

Tomarus cuniculus (Fabricius, 1801b): 20

\section{Saba}

Tomarus cuniculus: Gillett \& Gillett 2015: 4 - The Level, MPTG; English Quarter (Windwardside), MPTG; Windwardside, MPTG; The Bottom, MPTG; Upper Mountain Road (Maskerhorne Hill), MPTG; Lower Mountain Road (Windwardside), MPTG; Crispeen, MPTG

Tomarus cuniculus: Ratcliffe \& Cave 2015: 159 Crispeen, no leg.; Mountain Road, no leg.; The Bottom, no leg.; The Level, no leg.; Windwardside, no leg.

Tomarus cuniculus: Peck 2016: 94 - without further data

\section{St. Eustatius}

Tomarus cuniculus: This study - Bengalen Road, VZZ; Oranjestad, JB; Oranjestad, HM; Oranjestad, EOC, Oranjestad, AJW

\section{St. Martin}

Ligyrus cuniculus: Chalumeau \& Gruner 1977: 591 no locality, FC

Tomarus cuniculus: Ratcliffe \& Cave 2015: 159 - Mullet Bay, no leg.

New species record for St. Eustatius. Collected at light and from vegetation. Ratcliffe \& Cave (2015: 157) added Barbuda to the range as published by Peck $(2011,2016)$.

Tomarus fossor (Latreille, 1813): 11

\section{Bonaire}

Ligyrus fossor: Werner 1925: 556 - no locality, AG

Curaçao

Ligyrus (Ligyrus) fossor: Endrödi 1969: 54 - without further data

Not in Peck $(2011,2016)$ but listed by Ratcliffe \& Cave (2015: 164) for Antigua, a first record for the northern Lesser Antilles based on a single specimen. For the year of publication see Mac Gillavry (1931) and Bousquet (2016).

Family BUPRESTIDAE Leach, 1815: 85

The table in Brûlé et al. (2017) mentioned seven species for Saba, which is clearly erroneous. Hitherto, 
only the species below is known from this island (see also Ivie et al. 2009).

Subfamily BUPRESTINAE Leach, 1815: 85

Chrysobothris sabae Maier \& Ivie, 2013: 86 Saba

Chrysobothris sabae Maier \& Ivie, 2013: 86 - Spring Bay Trail, base of Old Booby Hill, DSS, JAS \& G.D. Alpert)

Chrysobothris sabae: Sikes 2020: GBIF - same as above Chrysobothris sabae: Orrell 2020: GBIF - same as above

Endemic to Saba.

Conognatha olivacea Saunders, 1869: 336

Curaçao

Pithiscus nickerli: Obenberger, 1924: 96 - without further data

Conognatha olivacea: Moore \& Lander 2010: 116 without further data

Family PTILODACTYLIDAE Laporte, 1836: 21 Ivie et al. (2009) listed one, as yet unpublished, species of this family from Saba.

\section{Family CHELONARIIDAE Blanchard, 1845: 70}

Chelonarium pilosellum Chevrolat, 1880a: 260 Saba

Chelonarium pilosellum: Peck 2016: 103 - without further data

Family ELATERIDAE Leach, 1815: 85

Ivie et al. (2009) listed four species of this family from Saba. Peck (2016) listed two which means that at least two, as yet unpublished, other species are present on the island.

Subfamily ELATERINAE Leach, 1815: 85

Dicrepidius ignotus Fleutiaux \& Sallé, 1890: 409

\section{Saba}

Dicrepidius ignotus: Peck 2016: 106 - without further data

\section{Physorhinus distigma Candèze, 1859: 390}

\section{St. Eustatius}

Physorhinus distigma: Schaaf 1971: 62 - without further data [leg. probably BM]

Not listed by Peck $(2011,2016)$ for the Antilles. Schaaf (1971: 62) also listed Antigua. In light of the disjunct distribution [i.e. Texas, Mexico, Belize, Honduras, Guatemala, Nicaragua, Costa Rica, Panama, Colombia, Peru, Ecuador, Brazil,
Paraguay, Argentina and the two Caribbean islands (Aguirre-Tapiero \& Johnson 2014)] and the fact that Schaaf described this species as extremely variable, Physorhinus distigma sensu Schaaf might prove to be a complex of related species.

Subfamily CARDIOPHORINAE Candèze, 1859: 4

Esthesopus poedicus Candèze, 1860: 277

St. Eustatius

Esthesopus poedicus: This study - The Quill, KB

St. Martin

Esthesopus poedicus: Chassain \& Touroult 2012: 65 airport, JHPB

New species record for St. Eustatius. Collected from a blacklight trap.

Subfamily AGRYPNINAE Candèze, 1857: 17

Aeolus circumscriptus (Germar, 1823): 46

St. Martin

Aeolus sp. aff. circumscriptus: Chassain \& Touroult 2012: 67 - Quartier d'Orléans, FC

See Bousquet (2016) for the year of publication of Germar's description.

Conoderus bifoveatus Palisot de Beauvois, 1807: 78 Saba

Conoderus bifoveatus: Peck 2016: 108 - without further data

\section{St. Eustatius}

Conoderus bifoveatus: This study - Botanical Garden, KB; Oranjestad, EOC

\section{St. Martin}

Conoderus bifoveatus: Chassain \& Touroult 2012: 65 - beach, JHPB; Colombier, FC; Grisette, FC; Philipsburg, FC; Quartier d'Orléans, FC

Conoderus bifoveatus: Touroult 2019a: GBIF - without locality, JHPB; Grisette, FC

New species record for St. Eustatius. Collected at light. For the year of publication see Menke (1963), Evenhuis (1997) and Bousquet (2016).

Conoderus castaneus (Fabricius, 1792a): 226 St. Martin

Conoderus castaneus: Chassain \& Touroult 2012: 65 Pic Paradis, FC

Heteroderes amplicollis (Gyllenhal, 1817): 141 St. Martin

Heteroderes amplicollis: Chassain \& Touroult 2012: 67 - no locality, JHPB

Heteroderes amplicollis: Touroult 2019a: GBIF - same as above

Lacon subcostatus (Candèze, 1857): 69

[St. Martin] 
Chassain \& Touroult (2012) suspected this species to be present on St. Martin as well as St. Barthélemy but is has not yet been collected there.

Family LAMPYRIDAE Rafinesque, 1815: 110

Subfamily LAMPYRINAE Rafinesque, 1815: 110

Aspisoma ignitum (Linnaeus, 1767): 645

St. Eustatius

Aspisoma ignitum: This study - The Quill, EOC

St. Martin

Aspisoma ignitum: Chalumeau in litt. 2020

New species records for St. Eustatius and St. Martin. The one from St. Eustatius hand-collected from vegetation. Touroult (Touroult 2019a) listed a specimen collected by Chalumeau on St. Martin on GBIF which was later deleted from his dataset for unknown reasons (Touroult in litt. 2020). Fortuné Chalumeau (in litt. 2020) confirmed this record and added that the species is quite present on the island. Also listed in Questel (2014) for St. Barthélemy and shown as present on the INPN (2020) map for St. Barthélemy with reference to Questel. It is not clear if vouchers are available.

Family DERMESTIDAE Latreille, 1804: 142 Ivie et al. (2009) listed one, as yet unpublished, species of this family from Saba.

\section{Attagenus fasciatus (Thunberg, 1795): 105 Bonaire \\ Attagenus fasciatus: This study - Rincón, JKW \\ New species record for Bonaire.}

Dermestes maculatus De Geer, 1774: 223

St. Eustatius

Dermestes maculatus: This study - Oranjestad, EOC

New species record for St. Eustatius. Many specimens were collected from a dead cow. Hitherto only known in the Lesser Antilles from Montserrat and Guadeloupe but suspected to be present throughout the archipelago (Peck 2016).

Trogoderma serraticorne (Fabricius, 1792b): 265

\section{Aruba}

Trogoderma anthrenoides: Háva 2003: 132 - without further data

Trogoderma anthrenoides (Sharp, 1902: 649) was synonymised with T. serraticorne by Háva (2016). Also listed by Beal (1960: 18) for Antigua, an island not listed by Peck $(2011,2016)$.

Family BOSTRICHIDAE Latreille, 1802: 202

Subfamily POLYCAONINAE Lesne, 1896: 96

Melalgus gonagrus (Fabricius, 1798): 156

\section{Saba}

Melalgus gonagrus: Peck 2016: 116 - without further data

Peck (2016) listed both this species and Melalgus caribeanus (Lesne, 1906): 396, for Montserrat. As far as we are aware the Ivie et al. (2008b) record of Melalgus caribeanus is the only published occurrence of this genus on Montserrat. Peck added that the two taxa might prove to be synonymous.

Subfamily BOSTRICHINAE Latreille, 1802: 202

Amphicerus cornutus (Pallas, 1772): 8

\section{Bonaire}

Schistocercus cornutus: Werner 1925: 556 - no locality, AG

[Curaçao]

Amphicerus cornutus: Scannell 2018: iNaturalist - Willemstad, P. Scannell

\section{St. Eustatius}

Amphicerus cornutus: This study - without further data

\section{St. Martin}

Schistoceros cornutus: Lesne 1899: 510 - without further data

New species record for St. Eustatius. Delivered at the Caribbean Netherlands Science Institute on 9-x-2015 without further data. As far as we are aware, Peck (2016) was the first to list Anguilla but he did so without the asterisk which indicates a new island record in his checklist.

Xylomeira tridens (Fabricius, 1792a): 362

St. Eustatius

Xylomeira tridens: This study - The Quill, JTS

[St. Martin]

Xylomeira tridens: Yokoyama 2013: 85 - without further data

New species record for St. Eustatius. Collected from a Malaise trap. Listed and photographed by Yokoyama (2013) and shown as present with reference to Yokoyama on the website of the INPN (2020) for St. Martin. It is not clear if vouchers are available.

Family ANOBIIDAE Fleming, 1821: 50

Ivie et al. (2009) listed nine, as yet unpublished, species of this family from Saba.

Subfamily DORCATOMINAE Thomson, 1859: 90

Cryptorama antillensis White, 1984: 85

\section{St. Eustatius}

Cryptorama cf. antillensis: This study - The Quill, EOC New provisional record for St. Eustatius. Beaten from vegetation. Elsewhere known from Cuba, Guadeloupe and Trinidad, provisionally from 
Montserrat, and a species near this from Guana, British Virgin Islands (White 1984, Valentine \& Ivie 2005, Ivie et al. 2008b).

\section{Petalium pici Lepesme, 1947: 220}

\section{St. Eustatius}

Petalium cf. pici: This study - Botanical Garden, $\mathrm{KB}$

New provisional record for St. Eustatius. Collected at light. This species is only known from Guadeloupe (Lepesme 1947).

Petalium LeConte, 1861: 204

\section{St. Eustatius}

Petalium species: This study - The Quill, EOC

A Petalium species differing from the species above. Beaten from vegetation.

\section{Tricorynus neltumae (Fisher 1942): 37}

\section{St. Eustatius}

Tricorynus cf. neltumae: This study - Botanical Garden, $\mathrm{KB}$

New provisional record for St. Eustatius. A single male specimen collected at light. Elsewhere, known from the Dominican Republic and Puerto Rico (White 1963).

Subfamily PTININAE Latreille, 1802: 112

\section{Bellesus cristithorax (Bellés, 1985): 231}

\section{Aruba}

Arachnomimus cristithorax: Philips 2000: 262 - without further data

\section{Bonaire}

Arachnomimus cristithorax: Philips 2000: 262 - without further data

Curaçao

Arachnomimus cristithorax: Philips 2000: 262 - without further data

\section{Pitnus longicornis Bellés, 1992: 182}

\section{Bonaire}

Pitnus longicornis Bellés, 1992: 182 - Lac Cai, no leg.; Klein Bonaire, no leg.; Playa Palu Calbas, no leg.

\section{Curaçao}

Pitnus longicornis Bellés, 1992: 182 - Fuik Baai, no leg.; Boca Grandi, no leg.

Pitnus robustus Bellés, 1992: 181

\section{Aruba}

Pitnus robustus Bellés, 1992: 181 - Hofje Fontein, no leg.; Sabana Blanco, no leg.; Boekoeti reef, no leg.; Seroe Colorado, no leg.

Curaçao

Pitnus robustus Bellés, 1992: 181 - Klein Curaçao, no leg.

Family TROGOSSITIDAE LatreiIIe, 1802: 159
Subfamily LOPHOCATERINAE Crowson, 1964: 297

Lophocateres pusillus (Klug, 1833): 71

[Curaçao]

Lophocateres pusillus: Barron 1971: 43 - without further data

Barron (1971) listed specimen(s) from the District of Columbia imported in beans from Curaçao. However, it is not clear if the species has established itself on the island. The citation for the original description is not Klug, 1832: 159 as in Blackwelder (1945) nor Klug, 1833: 159 as in Peck (2016). Klug's description was published twice, first as a separate publication of the Königlichen Akademie der Wissenschaften (Klug 1833: 71), later in the Abhandlungen der Königlichen Akademie der Wissenschaften zu Berlin (Klug 1834b: 159).

Family CLERIDAE Latreille, 1802: 110

Subfamily ENOPLIINAE Gistel, 1848a: [6]

Neorthopleura turnbowi Opitz, 2019: 995

Curaçao

Neorthopleura turnbowi Opitz, 2019: 995 - Christoffel Park, The Woods, RHT; Christoffel Park, Mountain Route, RHT; Copper Mine Trail, RHT; weg naar Playa Kanoa, RHT; Christoffel Park, Northern Route, RHT; Malpais Trail, RHT; Playa Kanoa, RHT; Santa Cruz, RHT; Playa Parasasa, RHT; Park Woods, RHT; Seru Jamanika, RHT; North Car Route, MCT; South Car Route, MCT; dry stream bed at Christoffelberg trailhead, MCT; Copper Mine, MCT

Endemic to Curaçao.

Subfamily KORYNETINAE Laporte, 1836: 34

Necrobia rufipes (De Geer, 1775): 165

St. Eustatius

Necrobia rufipes: This study - Oranjestad, EOC

[St. Martin]

Necrobia rufipes: Yokoyama 2013: 85 - without further data

New species record for St. Eustatius. Several specimens were collected from a dead cow. Listed and photographed by Yokoyama (2013) and shown as present with reference to Yokoyama on the website of the INPN (2020) for St. Martin. It is not clear if vouchers are available.

Family MELYRIDAE Leach, 1815: 87

Ivie et al. (2009) listed one, as yet unpublished, species of this family from Saba.

Subfamily MELYRINAE Leach, 1815: 87 


\begin{abstract}
[Curaçao]
Astylus lebasi: Sarkiss 2018: iNaturalist - Jan Doret, Sint Michiel, A. Sarkiss

Astylus lebasi: Scannell 2019: iNaturalist - Santa Catharina, P. Scannell

Several records with photo identified as Astylus lebasi Champion, 1918: 363 are listed on iNaturalist and, based on these, on GBIF. It could be this species but in the absence of a key and a modern revision they are here referred to Astylus species.
\end{abstract}

Family NITIDULIDAE Latreille, 1802: 131

Ivie et al. (2009) listed seven species of this family from Saba. Peck (2016) listed two which means that at least five, as yet unpublished, other species are present on the island.

Subfamily CILLAEINAE Kirejtshuk \& Audisio, 1986: 219

Conotelus conicus (Fabricius, 1801a): 603

St. Martin

Conotelus conicus: Jelínek \& Nicholas Evans 1982: 235

- no locality, HER

Subfamily CARPOPHILINAE Erichson, 1842: 148

Carpophilus Stephens, 1830: 50

\section{Curaçao}

Carpophilus pilosellus: Connell 1963: 90 - without further data

Introduced. As Peck (2016) already mentioned there is confusion regarding the limits of several species of Carpophilus. African and European specimens of $C$. pilosellus auct. nec Motschulsky, 1858: 41 were identified as $C$. truncatus Murray, 1864: 381 by Audisio (1982, 2011) and Kirejtshuk (1996). The true identity of the American specimens is as yet unknown. Carpophilus pilosellus Motschulsky, 1858 should be considered synonymous with C. mutilatus Erichson, 1843: 258 (Kirejtshuk 1996, Jelínek \& Audisio 2007).

Epuraea luteola Erichson, 1843: 272

Saba

Epuraea luteola: Peck 2016: 127 - without further data

Not described as member of the genus Haptoncus Murray, 1864: 401 by Erichson (1843) as quoted by Peck (2016).

Subfamily NITIDULINAE Latreille, 1802: 131

Lobiopa insularis (Laporte, 1840): 10 Saba

Lobiopa insularis: Peck 2016: 127 - without further data

\section{[St. Martin]}

Lobiopa insularis: Yokoyama 2013: 85 - without further data

Listed and photographed by Yokoyama (2013) and shown on the website of the INPN (2020) as present on St. Martin with reference to Yokoyama. It is not clear if vouchers are available.

Stelidota strigosa (Gyllenhal, 1808b): 140

\section{St. Eustatius}

Nitidula strigosa Gyllenhal, 1808b: 140 - no locality, JEF

Nitidula lusca Gyllenhal, 1808c: 140 - no locality, JEF Stelidota strigosa: This study - The Quill, EOC, MK \& AJW

Sieved from leaf litter. Despite the fact that both of Gyllenhal's names are based on specimens from St. Eustatius, Stelidota strigosa is only listed for the island by Parsons (1943) and not by subsequent authors including Blackwelder (1945) and Peck (2011, 2016). Also present on Montserrat (Ivie et al. 2008b). Peck (2016) did refer to Ivie et al. (2008b) under S. strigosa but listed their record under S. thoracica Kirsch, 1873: 142.

Subfamily CYBOCEPHALINAE Jacquelin du Val, 1858: 151

Cybocephalus caribaeus Smith, 2007: 167

Curaçao

Cybocephalus caribaeus Smith, 2007: 167 - Coral Specht, $3 \mathrm{~km}$. E. Willemstad, WES \& JMS

Cybocephalus caribaeus: Orrell 2020: GBIF - same as above

Family SMICRIPIDAE Horn, 1880: 268

Ivie et al. (2009) listed one, as yet unpublished, species of this family from Saba.

Family MONOTOMIDAE Laporte, 1840: 377

Ivie et al. (2009) listed two species of this family from Saba. Peck (2016) listed a single species which means that at least one, as yet unpublished, other species is present on the island.

Subfamily MONOTOMINAE Laporte, 1840: 377

Bactridium heydeni (Reitter, 1873a): 33

Curaçao

Bactridium heydeni: UGCA 2020: GBIF - Christoffel Park, Copper Mine Trail, RHT

Monotoma longicollis (Gyllenhal, 1827): 635

Curaçao

Monotoma longicollis: UGCA 2020: GBIF - Playa Santa

Cruz Road, RHT 
Monotoma spinicollis Aubé, 1837b: 463

Saba

Monotoma spinicollis: Peck 2016: 129 - without further data

The page number of the original description is 463, not 462 as in Blackwelder (1945) and Peck (2016).

Family SILVANIDAE Kirby, 1837: 110

Ivie et al. (2009) listed one, as yet unpublished, species of this family from Saba.

\section{Monanus concinnulus (Walker, 1858): 207}

\section{St. Eustatius}

Monanus concinnulus: This study - The Quill, EOC, MK \& AJW

New species record for St. Eustatius; introduced. Sieved from leaf litter. Peck (2016) listed Cathartus quadricollis (Guérin-Méneville, 1837): pl. 41 for Montserrat probably with reference to Ivie et al. (2008b: 249). However, there is no such record there. Ivie et al. (2008b) did list Monanus concinnus (sic!) (Walker) which very probably refers to this species. Monanus concinnulus was not listed in Peck (2016) for Montserrat nor is Ivie et al. (2008b) referenced by him.

Family PASSANDRIDAE Blanchard, 1845: 134

Taphroscelidia atratula (Grouvelle, 1916): 16 Curaçao

Taphroscelidia atratula: Burckhardt \& Slipinski 1991: 472 - Isla Hato, BM

Family PHALACRIDAE Leach, 1815: 116

Apallodes Reitter, 1873b: 130

Saba

Litolibrus species: Peck 2016: 134 - without further data

Gimmel (2013) synonymised Litolibrus Sharp, 1889: 258 with Apallodes.

Litostilbus testaceus (Fabricius, 1792b): 83 / Litostilbus tristriatus (Casey, 1890): 142

\section{Saba}

Ochrolitus triseriatus (sic!): Peck 2016: 134 - without further data

St. Eustatius

Litostilbus testaceus: This study - Botanical Garden, KB; The Quill, EOC

New species record for St. Eustatius. Peck (2016), probably based on Blackwelder (1945), who listed "Litostilbus testaceus Fabricius, 1775: 83" with the remark that there is a questionable record from St. Thomas. L. testaceus was described by Fabricius in 1792 as Sphaeridium testaceum with type locality
"America meridionalis Insulis" which was later restricted to St. Thomas by Gimmel (2013). There is also a record from the Cayman Islands (Thomas et al. 2013). At present Litostilbus contains two New World species: L. testaceus [lectotype digitised (Natural History Museum of Denmark 2020)] and L. tristriatus (Casey, 1890) [not Casey, 1893 as in Arnett et al. (2002) and Peck (2016), see Bousquet (2012) and Gimmel (2013)], type from Florida. In his genus-level revision of the family Phalacridae, Gimmel (2013) stated that the two species are probably synonymous. If Gimmel's impression is correct Litostilbus testaceus ( $\mathrm{Fa}-$ bricius, 1792) is the valid name for this species.

Family CRYPTOPHAGIDAE Kirby, 1826: 504

Subfamily ATOMARIINAE LeConte, 1861: 99

Curelius japonicus (Reitter, 1878): 181

Saba

Curelius japonicus: Peck 2016: 134 - without further data

Family LANGURIIDAE Hope, 1840: 190

Subfamily XENOSCELINAE Ganglbauer, 1899: 649

Loberus LeConte, 1861: 98

Saba

Loberus species Peck 2016: 135 - without further data

Family EROTYLIDAE Latreille, 1802: 233

Ivie et al. (2009) listed five, as yet unpublished, species of this family from Saba.

Subfamily EROTYLINAE Latreille, 1802: 233

Iphiclus sedecimguttatus (Olivier, 1792): 436

Curaçao

Brachysphaenus sedecimguttatus: Deelder 1942: 63 - no locality, Perroud

This species is sometimes referred to as Iphiclus maculatus (Voet, 1778) (e.g. Alvarenga 1977). Voet's name is however unavailable as it was published in a work not consistently binominal (Art. 11.4 of the Code). See also Skelley (2020).

Family CERYLONIDAE Billberg, 1820a: 47 Ivie et al. (2009) listed one, as yet unpublished, species of this family from Saba.

Family ENDOMYCHIDAE Leach, 1815: 116

Subfamily MEROPHYSIINAE Seidlitz, 1872: 39 


\section{Holoparamecus aelleni Rücker, 1988: 1027 Curaçao \\ Holoparamecus aelleni Rücker, 1988: 1027 - Hato Caves, VA \& PS; San Pedro Plane Caves, VA \& PS Endemic to Curaçao.}

Family COCCINELLIDAE Latreille, 1807: 70

Numerous species of this family have been introduced in the Antilles for biological control. These introduced species were not always correctly identified and it is also not always clear whether the various species actually established themselves on the islands. Moreover, records for this family are often anecdotal. Except for the various papers by Gordon, only Peck (2016, in part.) and Bennett \& Simmonds (1964) explicitly state that their records are based on vouchers. Duverger (2001) compiled a checklist for the Coccinellidae of the Lesser Antilles based on literature records and his own observations. It is unclear if these records are based on vouchers. Duverger's work has not been published but is available on the Internet. Ivie et al. (2009) listed 18 species of this family from Saba. The present paper contains information on four which means that at least 14, as yet unpublished, other species are present on the island.

Subfamily STICHOLOTIDINAE Weise, 1901: 430

\section{Coccidophilus cariba Gordon, 1978: 206 \\ Curaçao}

Coccidophilus cariba Gordon, 1978: 206 - no locality, FDB

Delphastus catalinae (Horn, 1895): 83

[St. Martin]

Delphastus catalinae Duverger 2001: no pagination without further data

Delphastus diversipes (Champion, 1913): 126

\section{Curaçao}

Delphastus diversipes: Bennett \& Simmonds 1964: 89 without further data

\section{St. Eustatius}

Delphastus diversipes: Bennett \& Simmonds 1964: 89 without further data

Delphastus pallidus (LeConte, 1878): 400

[St. Martin]

Delphastus pallidus: Duverger 2001: no pagination without further data

Delphastus pusillus (LeConte, 1852a): 135

\section{[St. Martin]}

Delphastus pusillus: Duverger 2001: no pagination without further data
Delphastus quinculus Gordon, 1994: 120

\section{[St. Martin]}

Delphastus quinculus: Duverger 2001: no pagination without further data

Until Gordon (1994) published his revision of Delphastus, species in this genus were often misidentified, a trend that still continues because of unfamiliarity with this work (see for instance Booth \& Polaszek 1996, Hoelmer \& Pickett 2003, González et al. 2012, González 2015). Reports of Delphastus species must thus be dealt with very critically. Duverger (2001) referred to literature records for $D$. catalinae and D. quinculus for St. Martin without mentioning the source(s). We have not been able to find these.

Subfamily SCYMNINAE Mulsant, 1846: 189

Specimens in this subfamily, especially living ones used in biological control, are difficult to identify and have often been the subject of misidentification and other confusion. Records of Scymninae are here dealt with critically.

\section{Clitostethus dispar (Sicard, 1929): 530}

\section{Curaçao}

Clitostethus dispar: Bennett \& Simmonds 1964: 82 without further data

\section{St. Martin}

Clitostethus dispar: Bennett \& Simmonds 1964: 82 without further data

Often confused with Nephaspis species (Cock 1985, Gordon \& Hilburn 1990).

Cryptolaemus montrouzieri Mulsant, 1853: 268

\section{[St. Martin]}

Cryptolaemus montrouzieri: Duverger 2001: no pagination - without further data

Decadiomus hughesi Gordon \& Hilburn, 1990: 279

\section{[St. Martin]}

Decadiomus hughesi: Duverger 2001: no pagination without further data

Diomus ochroderus (Mulsant, 1850): 951

Curaçao

Scymnus (Diomus) ochroderus: Bennett \& Simmonds 1964: 83 - without further data

Diomus roseicollis (Mulsant, 1853): 270

Curaçao

Diomus roseicollis: Peck 2006: 187 - without further data

St. Martin

Diomus roseicollis: Peck 2006: 187 - without further data 
Hyperaspis connectens (Thunberg, 1808): 157 Saba

Hyperaspis connectens: Bennett \& Simmonds 1964: 87 without further data

\section{St. Eustatius}

Coccinella connectens Thunberg, 1808: 157 - no locality, JEF

Hyperaspis connectens: Bennett \& Simmonds 1964: 87 without further data

Hyperaspis donzeli (Mulsant, 1850): 638

\section{[St. Eustatius]}

Hyperaspis donzeli: Bennett \& Simmonds 1964: 87 without further data

Gordon \& Canepari (2008) revised Hyperaspis and stated that Hyperaspis donzeli is only known from Brazil and Paraguay. They described the new species $H$. pseudodonzeli (see below) and listed a paratype from Curaçao. However, they did not investigate a specimen from St. Eustatius. Which of the two, if any, is present on St. Eustatius is unclear.

\section{Hyperaspis festiva Mulsant, 1850: 659}

\section{Curaçao}

Hyperaspis festiva: Bennett \& Simmonds 1964: 87 without further data

\section{[St. Martin]}

Hyperaspis festiva: Duverger 2001: no pagination without further data

Hyperaspis pseudodonzeli Gordon \& Canepari, 2008: 320

\section{Curaçao}

Hyperaspis donzeli: Bennett \& Simmonds 1964: 87 without further data

Hyperaspis pseudodonzeli Gordon \& Canepari, 2008: 320- Schottegatweg, JMC

\section{[St. Eustatius]}

Hyperaspis donzeli: Bennett \& Simmonds 1964: 87 without further data

See comment under Hyperaspis donzeli. Although the Gordon and Canepari paper was listed in the reference section of Peck (2016), he did not mention this species.

\section{Hyperaspis scutifera (Mulsant, 1850): 565 \\ Curaçao}

Hyperaspis scutifera: Gordon \& Canepari 2008: 303 Schottegatweg, no leg.; Damacor, no leg.; Zapateer, no leg.

Hyperaspis scutifera: Wheeler et al. 2010: 569 - same specimens as above

Nephaspis bootes Gordon, 1997: 18

\section{Curaçao}

[Nephaspis amnicola: Gordon 1972: 149 - no locality, FDB?]
Nephaspis bootes Gordon, 1997: 18 - Coral Specht, WES \& JMS

Nephaspis bootes: Peck 2006: 187 - without further data

In his first revision of Nephaspis Gordon (1972) listed a Nephaspis-specimen from Curaçao as $N$. amnicola. This taxon was later synonymised with $N$. oculata (Gordon 1985). In his second revision Gordon (1997) stated that $N$. oculata is originally a Gulf Coast species and all specimens from outside the United States (U.S.) listed in Gordon (1972) belong to other species. However, Vandenberg (2002) assumed Nephaspis to be neotropical and the U.S. population only established in scattered localities. Peck (2009a) on the other hand seemed to follow Gordon (1997), considering $N$. oculata a Nearctic species and suggesting that neotropical records of $N$. oculata are probably $N$. equuleus Gordon, 1997. Gordon's (1997) description was based on an different specimen than the one from F.D. Bennett which makes it unclear whether that particular specimen belongs here or is the species below.

Nephaspis oculata (Blatchley, 1917): 140

[Curaçao]

Nephaspis amnicola: Gordon 1972: 149 - no locality, FDB

\section{[St. Martin]}

Nephaspis amnicola: Gordon 1972: 149 - no locality, FJS

Nephaspis oculata: Duverger 2001: no pagination without further data

See also the text under the previous species. Gordon's (1997) statement that all specimens from non-U.S. localities of Nephaspis oculata listed in Gordon (1972) belong to other species and the fact that he did not list a specimen from St. Martin in his second revision make it unclear which Nephaspis species actually occurs on St. Martin. The St. Martin record of Duverger (2001) is based on literature, supposedly on Gordon's (1972) paper.

Scymnus floralis (Fabricius, 1792b): 260

\section{Curaçao}

Scymnus floralis: Bennett \& Simmonds 1964: 83 - without further data

\section{Saba}

Scymnus floralis: Bennett \& Simmonds 1964: 83 - without further data

\section{St. Eustatius}

Scymnus floralis: Bennett \& Simmonds 1964: 83 - without further data

\section{[St. Martin]}

Scymnus floralis: Duverger 2001: no pagination - without further data 
Stethorus albipes (Mulsant, 1850): 998

\section{St. Eustatius}

Stethorus caribus: Gordon \& Chapin, 1983: 245 - Fort Orange, FJS

This species is listed as Stethorus caribus in, among other papers, Duverger (2001), Valentine \& Ivie (2005), Peck $(2011,2016)$ and Bos et al. (2018). However, after examination of the lectotype of S. albipes, Gordon (1993) synonymised S. caribus with $S$. albipes. The lectotype designation by Gordon (1987) also added St. Barthélemy to the range of this species. Stethorus albipes is thus present on Puerto Rico, Cuba, Hispaniola, Guana, St. Barthélemy, St. Eustatius, Nevis, Montserrat, Antigua, Barbados, Grenada, St. Lucia, Colombia and Latin America.

Stethorus pseudocaribus Gordon \& Chapin, 1983 Bonaire

Stethorus pseudocaribus Gordon \& Chapin, 1983: 247 - Kralendijk, JMC

Stethorus pseudocaribus: Orrell 2020: GBIF - same as above

\section{Subfamily CHILOCHORINAEMulsant, 1846: 166}

\section{Chilocorus cacti (Linnaeus, 1767): 584}

\section{St. Eustatius}

Chilocorus cacti: This study - inland from Corre Corre Bay, JTS

[St. Martin]

Chilocorus cacti: Yokoyama 2013: 84 - without further data

Chilocorus cacti: Mlodinow 2017: iNaturalist - Saline d'Orient, S. Mlodinow

New species record for St. Eustatius. Listed and photographed by Yokoyama (2013) and shown as present with reference to Yokoyama on the website of the INPN (2020) for St. Martin. Listed for St. Barthélemy by Questel (2014). Also present on St. Kitts-Nevis (Cock 1985: 19, van Lenteren \& Bueno 2020: 407). It is not clear if vouchers are available for these records. An additional record from Anguilla on iNaturalist (Bourque 2019).

Subfamily COCCIDULINAE Mulsant, 1846: 266

Pseudoazya trinitatis (Marshall, 1912): 320 St. Eustatius

Azya trinitatis: Bennett \& Simmonds 1964: 91 - without further data

Also listed for St. Barthélemy by Questel (2014). It is not clear if vouchers are available.

Rodolia cardinalis (Mulsant, 1850): 906 [St. Martin]

Rodolia cardinalis: Yokoyama 2010: 79 - without further data
Vedalia cardinalis was described on page 906 and not 901 as mentioned in Peck (2016). Listed and photographed by Yokoyama (2010) for St. Martin. It is not clear if vouchers are available. Also introduced as a biological control agent against Icerya purchasi Maskell, 1878 (Hemiptera) on St. Kitts, Nevis, Antigua and Montserrat (Bennett 1971: 371, Cock 1985: 4-7, van Lenteren \& Bueno 2020: 405). Not listed by Peck (2011, 2016) for these islands.

Subfamily COCCINELLINAE Latreille, 1807: 70

Cheilomenes sexmaculata (Fabricius, 1781): 96

\section{Curaçao}

Cheilomenes sexmaculata: Assour \& Behm 2019: 864 Curaçao Zoo, Willemstad, JEB \& HRA

This species was first identified from a photo taken at the test site of the Dienst Landbouw, Veeteelt en Visserij (Office of Agriculture, Animal Husbandry and Fisheries) on Curaçao sent by Carel de Haseth (Naturalis 2018b). Later its occurrence on the island was confirmed in a paper by Assour \& Behm (2019).

Coleomegilla maculata (De Geer, 1775): 392

[Aruba]

Coleomegilla maculata: Mlodinow 2017: iNaturalist Palm Beach, S. Mlodinow

Coleomegilla maculata: Tromp 2019: iNaturalist - Bubali Bird Sanctuary, M. Tromp

Curaçao

Coleomegilla maculata: Bennett \& Simmonds 1964: 93 - without further data

\section{[St. Martin]}

Coleomegilla maculata: Duverger 2001: no pagination without further data

Coleomegilla maculata might prove to be a species complex (Krafsur \& Obrycki 2000, Pérez \& Hoy 2002 but also see Greenstone et al. 2011). Coleomegilla maculata is also listed for St. Martin by Nicolas (2012), probably based on Duverger (2001).

Cycloneda devestita (Mulsant, 1850): 299

[Aruba]

Cycloneda devestita: Oduber 2019: iNaturalist - Oranjestad, M. Oduber

Bonaire

Cycloneda devestita: This study - Rincón, JKW

[Curaçao]

Cycloneda devestita: Kruithof 2016: Observation.org Sint Willibrordus, F. Cools

Cycloneda devestita: Kruithof 2018: Observation.orgWillemstad, F. Cools; Grote Berg, F. Cools

Cycloneda devestita: Louwsma 2018: iNaturalist Christoffelpark, M. Louwsma

New speciessrecordefor Bonaire. com04/26/2023 08:17:17 AM 
Cycloneda sanguinea (Linnaeus, 1763): 10

Bonaire

Daulis sanguinea: Werner 1925: 556 - no locality, AG

\section{Curaçao}

Cycloneda sanguinea: Bennett \& Simmonds 1964: 93 without further data

[Saba]

Cycloneda sanguinea: Terpstra 2013a: Observation .org - Mount Scenery, M. Terpstra

Cycloneda sanguinea: Haber 2019: iNaturalist - The Bottom, E. Haber

\section{St. Eustatius}

Cycloneda sanguinea: This study - Knippinga Estate, THB; east coast, JTS; Oranjestad, AJW; Oranjestad, EOC

\section{[St. Martin]}

Cycloneda sanguinea: Duverger 2001: no pagination without further data

New species record for St. Eustatius. Also listed for St. Martin by Nicolas (2012) probably based on Duverger (2001). A record from Barbuda on iNaturalist (Wisco 2016).

Psylloborva lineola (Fabricius, 1792b): 283

Saba

Psyllobora lineola: Bennett \& Simmonds 1964: 94 without further data

\section{Psyllobora parvinotata Casey, 1899:101}

\section{[St. Martin]}

Psyllobora parvinotata: Yokoyama 2013: 84 - without further data

Listed and photographed by Yokoyama (2013) and shown as present on St. Martin with reference to Yokoyama on the website of the INPN (2020). It is not clear if vouchers are available. This might be the previous species.

Family CORYLOPHIDAE LeConte, 1852a: 141 Ivie et al. (2009) listed six species of this family from Saba. Peck (2016) listed a single species which means that at least five, as yet unpublished, other species are present on the island.

Subfamily PELTINODINAE Paulian, 1950: 19

\section{Holopsis Broun, 1883: 498}

\section{Saba}

Holopsis species: Peck 2016: 147 - without further data

Listed erroneously as Holopsis pellucidus by Bos et al. (2018). Peck (2016) clearly listed an undetermined Holopsis species from Saba.

Family LATRIDIIDAE Erichson, 1842: 122

Ivie et al. (2009) listed one, as yet unpublished, species of this family from Saba.
Family MYCETOPHAGIDAE Leach, 1815: 110

Ivie et al. (2009) listed one, as yet unpublished, species of this family from Saba.

Typhaea stercorea (Linnaeus, 1758): 357

\section{St. Eustatius}

Typhaea stercorea: This study - Oranjestad, EOC

Introduced. New species record for St. Eustatius. Collected with a yellow pan trap.

Family CIIDAE Leach, 1819b: 206

Ivie et al. (2009) listed three species of this family from Saba. Peck (2016) mentioned unidentified material of the genus Cis from the same island.

Subfamily CIINAE Leach, 1819b: 206

Cis Latreille, 1796: 50

Saba

Cis species: Peck 2016: 149 - without further data

Cis creberrimus Mellié, 1849: 357

St. Eustatius

Cis cf. creberrimus: This study - Oranjestad Bay, EOC

Collected from a tree fungus together with Cis melliei and on the same tree as Palorus cerylonoides. It keyed out as $C$. creberrimus in Lawrence (1971). CO1 barcoding yielded a relatively low match of $88 \%$ with a Brazilian specimen of that species in GenBank (Benson et al. 2005). Lawrence (1971) already noted that $C$. creberrimus is probably a species complex. For the year of publication see Evenhuis (2016).

Cis melliei Coquerel, 1850: 441

\section{St. Eustatius}

Cis melliei: This study - Oranjestad Bay, EOC

Collected from a tree fungus together with $C$ is creberrimus and on the same tree as Palorus cerylonoides. For the year of publication see Evenhuis (2016).

Family MORDELLIDAE Latreille, 1802: 183

Ivie et al. (2009) listed one, as yet unpublished, species of this family from Saba.

\section{Subfamily MORDELLINAE Latreille, 1802: 183}

Glipostenoda pallida (Champion, 1896a): 50

\section{St. Eustatius}

Glipostenoda pallida: This study - The Quill, EOC; The Quill, JTS

Beaten from vegetation and caught in a Malaise

trap. Downloaded from Brill.com04/26/2023 08:17:17AM 
Family COLYDIIDAE Billberg, 1820b: 394

Ivie et al. (2009) listed five, as yet unpublished, species of this family from Saba.

Family TENEBRIONIDAE Latreille, 1802: 165

Ivie et al. (2009) listed 12 species of this family from Saba. The present paper contains information on four species. Ivie and Hart (2016) and Hart and Ivie (2016) revised the species of the subfamily Opatrinae. The latter papers reduced the total number of species present on Saba with two. This means that at least six, as yet unpublished, other species are present on the island.

Subfamily LAGRIINAE Latreille, 1825: 381

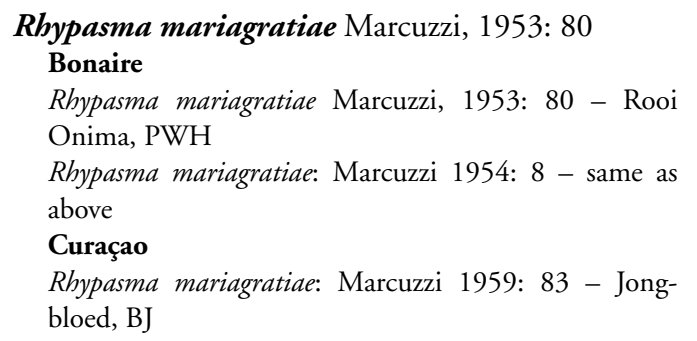

Rhypasma venezuelense Marcuzzi, 1953: 76

[Bonaire]

Rhypasma venezuelense Marcuzzi, 1953: 76 - Tanki Onima, PWH

Rhypasma venezuelense: Marcuzzi 1954: 7 - same as above

Rhypasma venezuelense: Marcuzzi 1977: 10 - Escarpment of Fontein, PWH

Without clarification, Marcuzzi (1984) listed only Rhypasma mariagratiae for Bonaire and placed a question mark for the occurrence of $R$. venezuelense on Bonaire. This could mean that he considered his earlier identifications erroneous. The genus Rhypasma was recently transferred from the subfamily Pimeliinae to Lagriinae by Nabozhenko et al. (2016).

Subfamily PIMELIINAE Latreille, 1802: 166

Ecnomosternum vermiculatum Gebien, 1928: 104 Bonaire

Ecnomosternum vermiculatum Werner 1925: 556 (nomen nudum) - no locality, AG

Ecnomosternum vermiculatum Gebien, 1928: 104 without further data

Ecnomosternum vermiculatum: Marcuzzi 1959: 81 - Fontein, PWH; Hofje Fontein, HJMG; Dos Pos, HJMG; Pos Hoeba, no leg.; Playa Grandi, Tanki Ventura, HJMG; no locality, RHC

Ecnomosternum vermiculatum: Freude 1967: 221 without further data

\section{Curaçao}

Ecnomosternum vermiculatum Werner 1925: 556 (nomen nudum) - no locality, without further data

Ecnomosternum vermiculatum Gebien, 1928: 104 without further data

Ecnomosternum vermiculatum: Marcuzzi 1954: 2 - Piscadera Hotel, no leg.; Cas Cord, no leg.; Willemstad, no leg.)

Ecnomosternum vermiculatum: Marcuzzi 1959: 81 Hofje Porto Marie, HJMG; Porto Marie, HJMG; Hofje Sint Kruis, HJMG; Scherpenheuvel, BMR; Jongbloed, BJ; Santa Marta, RHC

Ecnomosternum vermiculatum: Freude 1967: 221 without further data

Ecnomosternum vermiculatum: Marcuzzi 1977: 5 CARMABI, Piscadera Baai, PWH

For unknown reasons Marcuzzi (1984) listed Ecnomosternum vermiculatum only for Curaçao.

Epitragus aurulentus Kirsch, 1866: 189

Aruba

Epitragus aurulentus: Marcuzzi 1959: 81 - Eagle Colony, RHC

Epitragus aurulentus: Marcuzzi 1961a: 318 - no locality, PWH

Epitragus aurulentus: Rigatti-Luchini \& Camuffo 1962: 92 - no locality, PWH

Epitragus aurulentus: Marcuzzi 1962: 24 - Eagle Colony, no leg.

\section{Curaçao}

Epitragus aurulentus: Marcuzzi 1959: 81 - Jongbloed, BJ; Jongbloed, BJ; Santa Marta, RHC

Epitragus hummelincki Marcuzzi, 1961b: 22

Aruba

Epitragus hummelincki Marcuzzi, 1961b: 22 - no locality, PWH; Savaneta, JGB

Epitragus hummelincki: Marcuzzi 1961a: 322 - same as above

Epitragus hummelincki: Marcuzzi 1977: 5 - Bubali, no leg.; Bubali, PWH

Stictoderia gridelli Marcuzzi, 1954: 6

\section{Aruba}

Stictoderia gridelli Marcuzzi, 1954: 6 - Reef of Bucuti, PWH; Vader Piet, PWH; near Fontein, PWH

Endemic to Aruba.

Stictoderia subseriata Gebien, 1928: 101

\section{Bonaire}

Stictoderia werneri: Werner 1925: 556 (nomen nudum)

- no locality, AG

Stictoderia werneri Gebien, 1928: 102 - no locality, F. Werner [erroneous, leg. should be AG]

Stictoderia subseriata: Marcuzzi 1954: 5 - near Spelonk, PWH; Onima, PWH; Slagbaai, PWH; Klein Bonaire, SE, PWH 
Stictoderia subseriata: Marcuzzi 1959: Kibra Guarati, HJMG; Hofje Fontein, HJMG; Dos Pos, HJMG; Braziel, HJMG; Lagoen, no leg.; Lima, RHC

Stictoderia subseriata Marcuzzi 1977: 5 - Klein Bonaire, N shore, PWH, Paya Wecua, PWH; near Salinja, PWH; Ceru Pretu, Washington, PWH; Shishiribana, Washington, PWH; Rooi Tuna, Bolivia, PWH; Landhuis Boven Bolivia, PWH; Rooi Caohori, Bolivia, PWH; Washington gate, PWH

\section{Curaçao}

Stictoderia subseriata Werner 1925: 556 (nomen nudum) - without further data

Stictoderia subseriata Gebien, 1928: 101 - without further data

Stictoderia subseriata: Marcuzzi 1954: 5 - Klein Curaçao, PWH; Tafelberg S. Barbara, PWH

Stictoderia subseriata: Marcuzzi 1959: Boca Santa Marta, no leg.

Stictoderia subseriata Marcuzzi 1977: 5 - Seroe Cabajé, Porto Marie, PWH; coast of Klein St. Joris, PWH

\section{Tapinocomus subnudus Gebien, 1928: 103}

\section{Aruba}

Tapinocomus subnudus: Marcuzzi 1954: 4 Hooiberg, PWH; Hudishibana, PWH; Tibushi, PWH; Oranjestad, Pasanggrahan, no leg.; Santa Cruz, PWH; Hooiberg, PWH; Baranca Alto, PWH; Root Prins, PWH; Rooi Spoki, PWH; Cave of Quadirikiri, PWH; Vader Piet, PWH; Fontein, PWH; Jamanota, Seroe Cristal, PWH; Seroe Plat, PWH; Oranjestad, ADR; Dakota Airport, ADR; San Michael, NW of Oranjestad, no leg.

Tapinocomus subnudus: Marcuzzi 1959: 82 - San Barbola-Seroe Patrishi, HJMG; Altovista, HJMG; Macuarina-Warawara, HJMG; Oranjestad, HJMG; Westpunt-Malmok, HJMG; Santa Lucia-Andicuri, HJMG; Fontein, HJMG; Vader Piet-Seroe Kadushi, HJMG; Eagle Colony, no leg.; Seroe Colorado, PWH; Vader Piet, no leg.; Eagle Petroleum Company, PWH; no locality, RHC

Tapinocomus subnudus: Marcuzzi 1962: 24 - Oranjestad, ADR; Seroe Colorado, PWH

Tapinocomus subnudus: Marcuzzi 1977: 5 - Eagle Petroleum Company, PWH

\section{Bonaire}

Tapinocomus subnudus Werner 1925: 556 (nomen nudum) - no locality, AG

Tapinocomus subnudus Gebien, 1928: 103 - no locality, AG

Tapinocomus subnudus: Marcuzzi 1954: 4 - Kralendijk, no leg.; Lagoen, PWH,

Tapinocomus subnudus: Marcuzzi 1959: 82 - Bolivia, HJMG; Kralendijk, no leg.; no locality, RHC

Tapinocomus subnudus: Marcuzzi 1962: 24 - Bolivia, PWH

Tapinocomus subnudus: Marcuzzi 1977: 5 - Ceru Pretu, Washington, PWH; Shishiribana, Washington, PWH;
Rooi Tuna, Bolivia, PWH; Landhuis boven Bolivia, PWH

Tapinocomus subnudus:This study - Rincón, JKW

\section{Curaçao}

Tapinocomus subnudus: Marcuzzi 1954: 4 - Oost Seinpost, PWH; Willemstad, no leg.; Seroe Djerimi, PWH Tapinocomus subnudus: Marcuzzi 1977: 5 - Seroe Rondo, near Hato airport, PWH; Fort Waakzaamheid, Otrabanda, PWH

Tapinocomus subnudus: Marcuzzi 1983: 243 - without further data

Trientoma guadeloupensis Fleutiaux \& Sallé, 1890: 421

\section{St. Eustatius}

Trientoma guadeloupensis: Marcuzzi 1962: 25 - Northeast of Oranjestad, PWH; base of White Wall, PWH; top of White Wall, PWH; Quill above White Wall, PWH; Toby Gut, PWH

Trientoma guadeloupensis: Marcuzzi 1977: 6 - Sugar Loaf Gut, PWH

Trientoma guadeloupensis: This study - Boven National Park, AJW

Subfamily DIAPERINAE Latreille, 1802: 161

Adelina pici (Ardoin, 1977): 7

\section{St. Eustatius}

Adelina pici: This study - Botanical Garden, EOC

New species record for St. Eustatius. Collected from under bark. Listed for Antigua by Chalumeau (1982: 194), an island not mentioned by Peck $(2011,2016)$.

Phaleria fulva Fleutiaux \& Sallé, 1890: 423

\section{St. Eustatius}

Phaleria fulva: This study - Concordia Bay, JB

\section{St. Martin}

Phaleria fulva: Triplehorn 1980 - Simpson Bay, JFGC

Phaleria fulva: Watrous \& Triplehorn 1982: 17 - without further data, probably same as above

Phaleria fulva: Johnson \& Cora 2020: GBIF - same as first

New species record for St. Eustatius. Collected from washed-up beach material.

Phaleria picipes Say, 1824: 280

St. Eustatius

Phaleria picipes: This study - Concordia Bay, JB

St. Martin

Phaleria picipes: Watrous \& Triplehorn 1982: 20 - no locality, FC

New species record for St. Eustatius. Collected from washed-up beach material.

Phaleria punctipes LeConte, 1878: 421

\section{St. Martin}


Phaleria guadeloupensis: Marcuzzi \& d'Aguilar 1971: 83

- Baie aux Cailles, no leg.

Phaleria punctipes: Soldati \& Touroult 2014: 95 - Baie aux Cailles, no leg.

Triplehorn \& Watrous (1979: 283) added Anguilla (Sandy Island) and Barbuda to the range as published by Peck $(2011,2016)$.

\section{Phaleria testacea Say, 1824: 280}

\section{St. Eustatius}

Phaleria maculipennis: Marcuzzi 1962: 37 - Concordia Bay, PWH

Phaleria maculipennis: Marcuzzi 1977: 36 - Concordia Bay, PWH

Phaleria testacea: This study - Concordia Bay, JB; Concordia Bay, EOC

\section{St. Martin}

Phaleria angustata: Marcuzzi \& d'Aguilar 1971: 83 Baie aux Cailles, no leg.

Phaleria chevrolati: Marcuzzi 1977: 35 - Îlet Pinel, PWH

Phaleria testacea: Triplehorn \& Watrous 1979: 289 without further data

Triplehorn \& Watrous (1979: 291) added Barbuda, Antigua and Montserrat to the range as published by Peck $(2011,2016)$.

Phaleria Latreille, 1802: 162

\section{Aruba}

Phaleria cadaverina: Kleefstra 2019: Obervation .org - beach Oranjestad, N. Kleefstra

A photo on the citizen-science website Observation .org shows a Phaleria species erroneously identified as the European species cadaverina.

Trachyscelis aphodioides Latreille, 1809: 379

\section{St. Eustatius}

Trachyscelis aphodioides: This study - Concordia Bay, EOC

\section{St. Martin}

Trachyscelis flavipes: Marcuzzi \& d'Aguilar 1971: 83 Baie aux Cailles, no leg.

Trachyscelis aphodioides: Soldati \& Touroult 2014: 93 Baie aux Cailles, no leg.

New species record for St. Eustatius. Collected from sandy beach under algae. Introduced from the Mediterranean area, Europe.

\section{Ulomoides ocularis (Casey, 1891): 65}

St. Martin

Ulomoides ocularis: Chalumeau 1982: 193 - Colombier and Pic Paradis, FC

Subfamily OPATRINAE Brullé, 1832: 213

In two comprehensive papers Hart \& Ivie (2016) and Ivie \& Hart (2016) shed a large amount of light on the confusing taxonomy of this subfamily in the Antilles.

Blapstinus buqueti Champion, 1885: 128

\section{Aruba}

Blapstinus buqueti: Marcuzzi 1954: 12 - Hofje Westpunt, PWH; Solito, PWH

Blapstinus buqueti: Marcuzzi 1977: 26 - Eagle Petroleum Company, Druif, PWH

\section{Bonaire}

Blapstinus buqueti: Marcuzzi 1959: 84 - Hofje Fontein, HJMG; Hofje St. Kruis, HJMG; Hofje Savonet, HJMG; no locality, RHC

\section{Curaçao}

Blapstinus buqueti: Marcuzzi 1954: 12 - Hofje Hato, PWH; Hofje Groot Piscadera, PWH

Blapstinus buqueti: Marcuzzi 1959: 84 - Hofje Porto Marie, HJMG; Mahaai, BJ; Santa Marta, RHC

Blapstinus buqueti: Marcuzzi 1977: 26 - Hato, ADR; S of San Pedro, PWH

\section{Blapstinus curassavicus Marcuzzi, 1954: 14}

\section{Bonaire}

Blapstinus curassavicus Marcuzzi, 1954: 14 - Deenterra, PWH; Bronswinkel, PWH; Lagoen, PWH; Boca Onima, PWH; Klein Bonaire, near Cas, PWH

Blapstinus curassavicus: Marcuzzi 1959: 85 - Kibra Guarati, HJMG; no locality, HJMG; Playa Grandi, Tanki Ventura, HJMG; Bolivia, HJMG; Klein Bonaire, HJMG; Hofje Fontein, Spelonk, PWH; Klein Bonaire, RHC

Blapstinus curassavicus: Marcuzzi 1977: 26 - Montagne, W of Curuburu, PWH; Landhuis Guatemala, PWH; Seroe Ventana, Washington, PWH; Ceru Matijs, Washington, PWH; near Ceru Pretu, Washington, PWH; S Bolivia near Rooi Caohori, PWH; Playa Wecua, PWH Blapstinus curassavicus: Marcuzzi 1987: 101 - without further data

\section{Curaçao}

Blapstinus curassavicus Marcuzzi, 1954: 14 - Seroe Preioe, PWH; Kleine Berg, PWH; Martha Koosje, PWH; Plaja Djerimi, PWH; Seroe Baha So, PWH

Blapstinus curassavicus: Marcuzzi 1959: 85 - Hofje Porto Marie, HJMG; Cas Abau, HJMG; Seroe Cabajé, HJMG; Seroe di Cueba, HJMG; Playa Frankie, Spaanse Put, PWH; Boca Santa Marta, no leg.; Parera, no leg. Blapstinus curassavicus: Marcuzzi 1977: 26 - Seroe Stela, St. Jorisbaai, PWH; Spaanse Put near Playa Frankie, PWH; Seroe Patfa, Fuik, PWH; Seroe Cabajé, Porto Marie, PWH; Seroe Blanco, Fuik, PWH; Piscadera Baai, PWH; E of Boca Santa Marie, PWH; Piscadera, $\mathrm{N}$ part CARMABI area, PWH; Pestbaai, PWH; San Pedro, PWH; S of San Pedro, PWH; Ceru di Boca, Santa Martha, PWH; Ceru Rondo, E of Hato, no leg.; Put Klein St. Joris, PWH; no locality, PWH; Peninsula in inner bay of Santa Martha, PWH 
Blapstinus hummelincki Marcuzzi, 1954: 17 Bonaire

Blapstinus hummelincki Marcuzzi, 1954: 17 - E of Punt Vierkant, PWH; Boca Onima, PWH

Blapstinus hummelincki: Marcuzzi 1977: 27 - Boca Onima, E, PWH; Klein Bonaire, N part, PWH; Montagne, W of Curuburu, PWH; Playa Wectia, PWH; NE Salinja Matijs, Washington, PWH

\section{Curaçao}

Blapstinus hummelincki Marcuzzi, 1954: 17 - Seroe Pretoe, PWH; Schaarloo, PWH; Seroe Djerimi, PWH; Martha Koosje, PWH; NW. slope of S. Christoffel, PWH; Top of Seroe Christoffel, PWH; Seroe Baha So, PWH; Tafelberg S. Barbara, PWH

Blapstinus hummelincki: Marcuzzi 1977: 27 - Seroe Stela, St. Jorisbaai, PWH; Seroe Patla, Fuik, PWH; Boca Grandi, E, Savonet, PWH; Boca Grandi, W, PWH; Seroe Cabajé, Porto Marie, PWH; Seroe Pretoe, Fuik, PWH; Hofje St. Kruis, PWH; Piscadera, N part CARMABI area, PWH; Pestbaai, PWH; Ceru Rondó, E of Hato, PWH

Blapstinus opacus Mulsant \& Rey, 1859: 122 St. Eustatius

Clapstinus opacus: Marcuzzi 1957: 129 - without further data

Blapstinus opacus: Marcuzzi 1962: 36 - East of Oranjestad, PWH

Blapstinus opacus: This study - botanical Garden, EOC; Oranjestad, EOC; Zeelandia, JTS; Oranjestad, AJW

\section{St. Martin}

Blapstinus opacus: Marcuzzi 1962: 36 - Tintamarre, PWH

Blapstinus opacus martinensis Marcuzzi, 1977: 29 Grand Case, PWH

Also present on Antigua (Marcuzzi 1957: 129, Ivie \& Hart 2016: 466), an island not listed by Peck $(2011,2016)$.

\section{Blapstinus orchilensis Marcuzzi, 1951: 74 Aruba}

Blapstinus orchilensis occidentalis Marcuzzi, 1954: 15 Seroe Canashito, PWH; Heintje Croes, PWH; Solito, PWH; Reef of Bucuti, PWH; Vader Piet, PWH; Seroe Cristal, PWH; Seroe Plat, PWH; Hofje Fontein, PWH; Bucuti, PWH

Blapstinus orchilensis occidentalis: Marcuzzi 1959: 86 no locality, HJMG; no locality, RHC

Blapstinus orchilensis occidentalis: Marcuzzi 1977: 30 Eagle Petroleum Company, PWH

\section{Bonaire}

Blapstinus orchilensis occidentalis Marcuzzi, 1954: 15

- Tanki Onima, PWH; Bronswinkel, PWH; Fontein, PWH; Hofje Fontein, PWH; near Pos Dominica, PWH; Rooi Onima, PWH; Boca Onima, PWH
Blapstinus orchilensis occidentalis: Marcuzzi 1959: 86 Kibra Guarati, HJMG; Hofje Fontein, HJMG; Dos Pos, HJMG; no locality, RHC

Blapstinus orchilensis occidentalis: Marcuzzi 1977: 30 Hofje Fontein, PWH; Klein Bonaire, NW part., PWH; Playa Wecua, PWH; Ceru Matijs, Washington, PWH; Hofje Bronswinkel, Washington, PWH

Blapstinus orchilensis occidentalis: Marcuzzi 1987: 100 without further data

\section{Curaçao}

Blapstinus orchilensis occidentalis Marcuzzi, 1954: 15 $\mathrm{N}$ of Tafelberg S. Barbara, PWH; Hofje Halo, PWH; Hofje St. Kruis, PWH; Rooi Cajoeda, PWH; Hofje Groot S. Martha, PWH; Hofje Groot Piscadera, PWH; Seroe Baha So, PWH; Hofje Groot St. Joris, PWH

Blapstinus orchilensis occidentalis: Marcuzzi 1959: 86 Hofje St. Kruis, PWH

Blapstinus orchilensis occidentalis: Marcuzzi 1977: 30 - Top of Seroe Commandant, St. Kruis, PWH; Boca Grandi, W, Savonet, PWH; Hofje St. Kruis, PWH; Piscadera, N part CARMABI area, PWH; Hato, near Wandongo, PWH; Westpunt Baai, PWH; Ceru Rondo, E of Hato, PWH; Seroe di Boca, Klein St. Joris, PWH

Diastolinus leewardensis Hart \& Ivie, 2016: 498

\section{Saba}

Diastolinus puncticollis: Marcuzzi 1957: 128 - without further data

Diastolinus puncticollis: Marcuzzi 1962: 26 - Road to Bottom, PWH

Diastolinus puncticollis: Marcuzzi 1977: 22 - The Level, Windwardside, PWH; Road to Bottom, PWH; Tom's Gut, $S$ of Rendez-Vous, PWH

Diastolinus sallei: Marcuzzi 1977: 22 - The Level, Windwardside, PWH

Diastolinus puncticollis: Marcuzzi 1983: 244 - The Level, no leg.; Bottom, no leg.

Diastolinus leewardensis Hart \& Ivie, 2016: 498 - Windwardside, RSM; Fort Bay Gut, RSM; Hells Gate, RSM; Hotel Scout's Place, Windwardside, DSS; Mount Scenery Trail, DSS; beach Giles Quarter Trail, JAS; Dancing Place Trail, DSS \& JAS; Boobie Hill, JAS; near Boobie Hill, DSS \& JAS; near Boobie Hill, DSS \& JAS; Dancing Place Trail, MAI; Mountain Road, MPTG Diastolinus leewardensis: Johnson \& Cora 2020: GBIF - Windwardside, RSM; Fort Bay Gut, RSM

\section{St. Eustatius}

Diastolinus puncticollis: Marcuzzi 1957: 128 - without further data

Diastolinus puncticollis: Marcuzzi 1962: 26 - East of Oranjestad, PWH; Toby Gut near Quill, PWH; Big Gut near White Wall, PWH; The Quill above White Wall, PWH; The Quill above Glass Bottle, PWH

Diastolinus leewardensis Hart \& Ivie, 2016: 498 - Glass Bottle, PWH; Venus Bay, MAI \& N. Esteban; The Quill, MAI 
Diastolinus leewardensis: This study - Botanical Garden, EOC; Botanical Garden, KB; The Quill, AJW; Oranjestad, AJW; Oranjestad, EOC

Collected during this study from under stones, by beating and at light.

Diastolinus perforatus (Schönherr, 1806): 146 St. Martin

Diastolinus clathratus: Marcuzzi 1957: 128 - without further data

Diastolinus perforatus: Marcuzzi 1957: 128 - without further data

Diastolinus clathratus: Marcuzzi 1962: 27 - Old Battery, east of Great Bay, PWH

Diastolinus perforatus: Marcuzzi 1962: 27 - Old Battery Hill, PWH; Point Blanche, PWH; shore of Great Bay near Point Blanche, PWH; Old Battery, east of Great Bay, PWH; Cul de Sac bridge, PWH; Agricultural Experiment Station St. Peter, Cul de Sac, PWH; Experiment, east of Great Saltpond, PWH; Meschrine Hill near Simson Bay, PWH; Lowlands near Flamingo Pond, PWH; Little Key in Simson Bay lagoon, PWH; Pelican Key, Island, PWH; Little Bay Pond, PWH; Point Blanche Bay, PWH; Lowlands at Mullet Pond Bay, PWH; Sinkhole of Devil's Hole Cave, PWH

Diastolinus clavatus: Marcuzzi 1977: 13 - Point Blanche Bay, PWH; Philipsburg, PWH

Diastolinus perforatus: Marcuzzi 1977: 19 - Old Battery, PWH; Colline Nettlé, PWH; Point Blanche Bay, PWH; Fort Willem, PWH; Point Blanche, PWH; N Point Blanche Bay, PWH; Backy Hill, Prince's Quarter, PWH; Hope Hill, PWH; Belle Hill, N Grand Case, PWH; La Croisade, PWH; Morne aux Cabris, PWH; Cupecoy Bay Hill, PWH; Mildrum, Cul-de-Sac, PWH; Point Blanche, PWH; N of Cupecoy Bay, PWH; Grand Etang, PWH; Tintamarre, Bluff of Baie Blanche, PWH; W of Oysterpond, PWH; First Stick Hill, PWH; Cocksies, PWH; Guana Ridge, PWH

Diastolinus perforatus: Marcuzzi 1983: 246 - Mildrum, Cul de Sac, no leg.

Diastolinus clavatus: Marcuzzi 1987: 95 - Point Blanche, no leg.

Diastolinus clathratus: Marcuzzi 2001: 250 - Grande Case, Hope Estate, DB

Diastolinus mulsanti: Marcuzzi 2001: 251 - Grande Case, Hope Estate, DB

Diastolinus clathratus: Soldati \& Touroult 2014: 99 Grande Case, Hope Estate, DB

Diastolinus mulsanti: Soldati \& Touroult 2014: 99 Grande Case, Hope Estate, DB

Diastolinus perforatus: Hart \& Ivie 2016: 501 - Old Fort Hill, JFGC; Marigot, HFH \& FM; Point Blanche Bay, PWH; N of Cupecoy Bay, PWH; Mullet Bay, RSM; Pto. Blande, MAI \& L.L. Ivie)

Diastolinus perforatus: Johnson \& Cora 2020: GBIF Mullet Bay, RSM
Goajiria curta (Mulsant \& Rey, 1859): 93 Aruba

Diastolinus curtus curtus: Marcuzzi 1954: 8 - Tibushi, PWH; Heintje Croes, PWH; Man Plaisir, PWH; Solito, PWH; Hooiberg, PWH; Santa Cruz, PWH; Baranca Alto, PWH; Vader Piet, PWH; Seroe Cristal, PWH; Seroe Plat, PWH; Oranjestad, ADR; Sabana Blancoe, PWH; St. Michael, NW of Oranjestad, PWH

Diastolinus curtus curtus: Marcuzzi 1959: 83 - San Barbola-Seroe Patrishi, HJMG; Macuarina-Warawara, HJMG; Westpunt-Malmok, HJMG; Arikok, HJMG; Vader Piet-Seroe Kadushi, HJMG; Rooi Juditi-Piedra di Moelina, HJMG; Vader Piet, PWH; Seroe Colorado, PWH; Eagle Petroleum Company, PWH

Diastolinus curtus curtus: Marcuzzi 1977: 13 - Eagle Petroleum Company, PWH; Seroe Wara-Wara, PWH

Diastolinus curtus: Marcuzzi 1987: 97 - without further data

\section{Bonaire}

Diastolinus curtus curtus: Marcuzzi 1954: 8 - Bronswinkel, PWH

\section{Curaçao}

Diastolinus curtus Mulsant \& Rey, 1859: 93 - no locality, AS

Diastolinus curtus curtus: Marcuzzi 1954: 8 - Koenoekoe Abau, PWH

Diastolinus curtus curtus: Marcuzzi 1959: 83 - Seroe Domi, PWH; Santa Maria-Hato, HJMG; Willemstad, BMR; Parera, Santa Marta, RHC

Diastolinus curtus curtus: Marcuzzi 1977: 13 - Fort Waakzaamheid, Otrabanda, PWH

Nevisia barbudensis (Marcuzzi, 1962): 29

Saba

Clapstinus barbudensis: Marcuzzi 1957: 129 (nomen nudum) - without further data

Diastolinus barbudensis Marcuzzi, 1962: 29 - road to The Bottom, PWH

Diastolinus barbudensis antiguanus: Marcuzzi 1977: 11 - road to The Bottom, PWH [other specimens than those listed above]

Ivie \& Hart (2016) added Anguilla and St. Kitts to the range as published by Peck $(2011,2016)$.

Opatrinus clathratus (Fabricius, 1787a): 379

\section{St. Eustatius}

Opatrinus clathratus: This study - The Quill, EOC; The Quill, AZ

[St. Martin]

Opatrinus clathratus: Peck 2011: 33 - without further data

Opatrinus clathratus: Peck 2016: 160 - without further data

New species record for St. Eustatius. Collected from under stones on a steep forested hill side. Except for some speculations in a report in The 
Agricultural News (Anonymous 1905 as Hopatrinus gemellatus), Peck (2011) was the first to list St. Martin for this species. Peck included Diastolinus clathratus Marcuzzi 1962: 27; 1977: 13; 1984: 77 and Marcuzzi \& d'Aguilar 1971: 80 in the synonymy but these all belong to $D$. perforatus (see Hart \& Ivie 2016). It is unclear whether Peck actually saw a specimen from St. Martin, or the island record is related to the historically very confusing use of the specific name clathratus in Opatrinae (Iwan 1995) and thus erroneous. Its occurrence on St. Martin seems not unlikely. Usually quoted as first described by Fabricius in 1792b: 90 but his 1787 publication contains (almost) the same description. Opatrinus clathratus is also mentioned for Anguilla in several reports in The Agricultural News (Anonymous 1904, 1905, 1910; all as H. gemellatus) and from St. Barthélemy by Questel (2018: 18).

Ulus hirsutus Champion, 1885: 133

\section{Aruba}

Ulus hirsutus Lumen et al. 2019: 832 - California Dunes near lighthouse, JMS \& WES

Subfamily TENEBRIONINAE Latreille, 1802: 165

Alphitobius laevigatus (Fabricius, 1781): 90

Aruba

Alphitobius laevigatus: Marcuzzi 1962: 24 - Eagle Colony, PWH

Alphitobius laevigatus: Marcuzzi 1977: 39 - Oranjestad, PWH; Tunnel of Love near Rincón, PWH

Curaçao

Alphitobius laevigatus: Marcuzzi 1954: 26 - Agricultural Experiment Station Cas Cord, PWH; Willemstad, PWH

Alphitobius laevigatus: Marcuzzi 1977: 39 - Cueba di Noordkant, PWH

Saba

Alphitobius laevigatus: Marcuzzi 1962: 38 - Bat Hole, PWH

\section{St. Martin}

Alphitobius laevigatus: Marcuzzi 1962: 38 - Devil's Hole, PWH; no locality, RHC

Alphitobius laevigatus: Marcuzzi 1977: 39 - Devil's Hole, PWH; Philipsburg school, PWH

\section{Hypogena biimpressa (Latreille, 1813): 17}

\section{[Curaçao]}

Ulosonia biimpressa: Marcuzzi 1977: 41 - CARMABI, Piscadera Baai, PWH

The year of publication of this species is often cited as 1833. However, the second volume of von Humboldt \& Bonpland's "Recueil d'observations de zoologie et d'anatomie comparée faites dans l'océan Atlantique", in which Latreille's descriptions were published, was issued in seven livraisons (8-14, in 1813-1832). Tenebrio biimpressus was published on page 17 of the eighth livraison, which was issued in 1813 (Mac Gillavry 1931, Bousquet 2016). Based on the erroneous citation, Grimm et al. (2018) synonymised Hypogena biimpressa with $H$. brasilica (Perty, 1830). However, because Latreille's name was published 17 years earlier it should stand as the valid name of this species.

Grey \& Smith (2020) recently revised Hypogena and designated a neotype for $H$. biimpressa. They did not list this species nor $H$. tricornis for $\mathrm{Cu}-$ raçao but described the new species below from, among others, specimens from the island. It is as yet unclear whether $H$. biimpressa is also part of the fauna of Curaçao.

Hypogena hirsuta Grey \& Smith, 2020: 238 Curaçao

Hypogena hirsuta Grey \& Smith, 2020: 238 - Savonet, JMS \& WES; SE Lagun, WES, RHT \& MCT

Hypogena tricornis (Dalman, 1823): 59

[Curaçao]

Ulosonia tricornis: Marcuzzi 1954: 26 - no locality, $\mathrm{PWH}$

There are no vouchers for Curaçao. Marcuzzi himself reported that the specimens collected by Wagenaar Hummelinck were lost. Spilman (1973) clarified some nomenclatural problems with the genera Hypogena and Ulosonia. Bousquet \& Bouchard (2013) stated that $\mathrm{Hy}$ pogena tricornis Palisot de Beauvois, 1834: 199 from North America is not the same as Phaleria tricornis Dalman, 1823 from Jamaica as was mentioned by Spilman. This would make $H$. tricornis Palisot de Beauvois, 1834 a nomen nudum.

Marcuzzi (1954) first referred his Curaçao specimens to the concept of Laporte (1840) who mentioned Palisot de Beauvois as the author but later listed them as Ulosonia tricornis (Dalman, 1823) in his catalogue of the West Indies (1984). Bousquet et al. (2018) considered the names of Laporte and Dalman different nomenclatural acts which are probably synonymous. Grey \& Smith (2020) did list the paper by Bousquet et al. but did not comment on the issue. They did not list this species nor $H$. biimpressa for Curaçao but described the new species above from, among others, specimens from the island. It is unclear whether $H$. tricornis is also part of the fauna of Curaçao. 
Palorus cerylonoides (Pascoe, 1863): 129 St. Eustatius

Palorus cerylonoides: This study - Oranjestad Bay, EOC

Introduced. New species record for St. Eustatius. Collected from under bark on the same tree as the tree fungus with $C i s \mathrm{cf}$. creberrimus and $C$. melliei.

Platydema Laporte \& Brullé, 1831: 350

Curaçao

Platydema species: Marcuzzi 1959: 87 - Hofje St. Kruis, HJMG; Hofje St. Kruis, PWH

Tribolium castaneum (Herbst, 1797): 282

\section{Curaçao}

Tribolium castaneum: Marcuzzi 1954: 26 - Willemstad, no leg.

Tribolium castaneum: Marcuzzi 1959: 87 - same as above

Tribolium confusum Jacquelin du Val, 1862: 181

\section{Aruba}

Tribolium confusum: Marcuzzi 1959: 87 - Fontein, HJMG; no locality, HJMG

This species was not described in the fourth part of Jacquelin de Val's "Genera des coléoptères d'Europe", as quoted by Blackwelder (1945), but in the Catalogue of the series which was issued with separate pagination. See further Bousquet (2016) for the year of publication.

Trichoton curvipes Champion, 1885: 136

\section{Curaçao}

Trichoton curvipes: Marcuzzi 1959: 86 - Hofje Savonet, HJMG; Playa Frankie, Spaanse Put, PWH

Trichoton curvipes: Marcuzzi 1977: 33 - Spaanse Put near Playa Frankie, PWH; Top Seroe Commandant, St. Kruis, PWH; Boca Grandi, E cliff, Savonet, PWH

Trichoton curvipes: Ferrer \& Moraguès 2001: 506 "Pla 560" [should be Sta. 560 = Spaanse Put near Playa Frankie], PWH

\section{Zophobas atratus (Fabricius, 1775): 256 \\ Aruba}

Zophobas cf. atratus: Marcuzzi 1954: 27 - Oranjestad, no leg.

Zophobas rugipes: Marcuzzi 1959: 87 - Oranjestad, PWH

Zophobas batavorum Marcuzzi, 1959: 88 - Fontein, HJMG

Zophobas atratus: Marcuzzi 1959: 90 - Oranjestad, no leg.

Zophobas rugipes: Marcuzzi 1962: 24 - San Nicolas, JGB; specimen without further data

Zophobas batavorum: Marcuzzi 1977: 42 - Oranjestad, PWH
Zophobas rugipes: Marcuzzi 1977: 42 - Oranjestad, PWH

Zophobas atratus: Ferrer 2011: 297 - without further data

\section{Bonaire}

Zophobas cf. atratus: Werner 1925: 556 - no locality, AG

Zophobas species: Marcuzzi 1954: 27 - Fontein, PWH; Hofje Fontein, PWH; Boca Onima, PWH

Zophobas batavorum Marcuzzi, 1959: 88 - Playa Grandi - Tanki Ventura, HJMG; Fontein, PWH; Hofje Fontein, PWH; Boca Onima, PWH; no locality, RHC

Zophobas batavorum: Marcuzzi 1977: 42 - Hofje Fontein, PWH; Landhuis Bacuna, PWH

Zophobas batavorum: Marcuzzi 1987: 108 - without further data

Zophobas atratus: Ferrer 2011: 297 - without further data

\section{Curaçao}

Zophobas cf. rugipes: Marcuzzi 1954: 27 - Willemstad, no leg.; Groot Piscadera, PWH

Zophobas rugipes: Marcuzzi 1959: 87 - Willemstad, BMR; Willemstad, no leg.; Groot Piscadera, PWH Zophobas batavorum Marcuzzi, 1959: 88 - Newport Santa Barbara, PWH; Tafelberg Santa Barbara, PWH; Piscadera Bay, no leg.; Santa Marta, no leg.; Santa Marta, RHC

Zophobas rugipes: Marcuzzi 1962: 24 - Willemstad, no leg.

Zophobas batavorum: Marcuzzi 1962: 24 - Willemstad, no leg.

Zophobas batavorum: Marcuzzi 1977: 42 - Top of Seroe Commandant, St. Kruis, PWH; Hato, W of airport, PWH

Zophobas atratus: Ferrer 2011: 297 - station 207 [= Newport, near Cave, Sta Barbara], PWH

Zophobas atratus: This study - Suffisant, RK

Saba

Zophobas rugipes: Marcuzzi 1962: 39 - Bottom, in house, no leg.; Windwardside, RHC

\section{St. Eustatius}

Zophobas atratus: This study - Oranjestad, AJW

\section{St. Martin}

Zophobas rugipes: Marcuzzi 1962: 39 - St. Peter, Cul de Sac, PWH; Cul de Sac bridge, PWH

Zophobas batavorum: Marcuzzi 1977: 42 - Agricultural Experiment Station St. Peter, PWH

Zophobas atratus: Marcuzzi 1987: 108 - Mildrum, no leg.

Zophobas atratus: Ferrer 2011: 297 - no locality, E. Polvent [ambiguously listed as "Guadalupe, Saint Martin". Before 2007 St. Martin was part of the département of Guadeloupe]

Zophobas atratus: Soldati \& Touroult 2014: 103 - Oyster Pond, CD 
New species record for St. Eustatius. Collected from an urban site littered with dog faeces and household waste.

Subfamily ALLECULINAE Laporte, 1840: 242

\section{Lobopoda Solier, 1835b: 233}

\section{St. Eustatius}

Lobopoda species: This study - The Quill, EOC

Two female and one male specimens were collected from under stones. The male genitalia do not match any of those published by Campbell (1971).

Family OEDEMERIDAE Latreille, 1810: 216 Ivie et al. (2009) listed one, as yet unpublished, species of this family from Saba.

Family SALPINGIDAE Leach, 1815: 106

Ivie et al. (2009) listed three, as yet unpublished, species of this family from Saba.

Family ANTHICIDAE Latreille, 1819: 363

Subfamily ANTHICINAE Latreille, 1819: 363

Acantbinus trifasciatus (Fabricius, 1801b): 291 Aruba

Anthicus laterotuberculatus: Buck, 1960: 67 - Fontein, HJMG

Acanthinus trifasciatus: Werner 1966: 1272 - same specimens as above but erroneously listed with Fontein as leg. instead of as locality

\section{Bonaire}

Anthicus laterotuberculatus: Buck, 1960: 67 - Fontein, HJMG

Acanthinus trifasciatus: Werner 1966: 1272 - same specimens as above but erroneously listed with Fontein as leg. instead of as locality

Curaçao

Anthicus laterotuberculatus: Buck, 1960: 67 - Porto Marie, HJMG

Acanthinus trifasciatus: Werner 1966: 1272 - same specimens as above but erroneously listed with Fontein as leg.

Bonadona (1981: 284) listed a specimen from St. Barthélemy, an island not mentioned by Peck (2011, 2016). Not endemic to the ABC islands as listed (as Anthicus laterotuberculatus) by Debrot (2006).

Subfamily incertae sedis

Atenizoides curacaoae Gilmour, 1968: 103 Curaçao

Atenizoides curacaoae Gilmour, 1968: 103 - Piscadera Baai, CARMABI, RHC
Atenizoides curacaoae: Philips \& Ivie 1989: 162 - same specimen as above

Gilmour (1968) described this genus and species as a member of the Cerambycidae. Philipps \& Ivie (1989) transferred it to the family Anthicidae. Endemic to Curaçao.

Family ADERIDAE Csiki, 1909: 5

Csiki (1909) published this name on page 5, not 6 as listed in Bouchard et al. (2011). Ivie et al. (2009) listed four, as yet unpublished, species of this family from Saba.

\section{Ganascus Casey, 1895: 774}

\section{St. Eustatius}

Ganascus species: This study - Botanical Garden, KB; The Quill, KB; The Quill, JTS

New genus record for St. Eustatius. Collected at light and in Malaise trap.

Family SCRAPTIIDAE Gistel, 1848b: [11]

Subfamily ANASPIDINAE Mulsant, 1856: 85

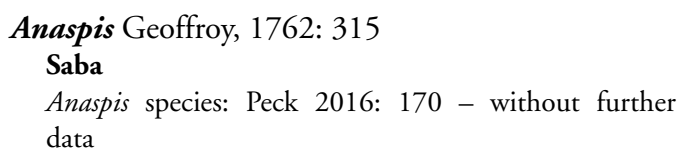

Family CERAMBYCIDAE Latreille, 1802: 211

Ivie et al. (2009) listed 13 species of this family from Saba. The present paper contains information on 12 which means that at least one, as yet unpublished, other species is present on the island.

Subfamily PRIONINAE Latreille, 1802: 212

Hovorodon maxillosum (Drury, 1773): 133

\section{St. Martin}

Stenodontes maxillosus: Lameere 1902: 97 - without further data

Nothopleurus maxillosus: Villiers 1980b: 141 - Cul-deSac, AD

Nothopleurus maxillosus: Chalumeau \& Touroult 2005: 45 - Concordia, DE

Hovorodon maxillosum: Touroult 2019b: GBIF - no locality, M. Yokoyama

The ICZN (1957) ruled in Opinion 474 that the date of publication of the index, published with the second volume of Drury's "Illustrations of natural history" in 1773, contains names formed in accordance with the principles of binominal nomenclature, and as such is the official date of publication of the species described in the first and second volume (Bousquet 2016). See further Santos-Silva et al. (2010) for the page number. 
Peck (2016) listed Nevis, probably based on Santos-Silva et al. (2010). It is certainly possible that this species is present there. However, Santos-Silva et al. (2010) referred to Gahan (1895) for their Nevis record but there is no record for that island there. Gahan (1895) only listed Guadeloupe, Barbuda and St. Kitts (as St. Christophers).

Mallodon spinibarbe (Linnaeus, 1758): 390

Aruba

Stenodontes (Mallodon) spinibarbis: Gilmour 1968: 87 Oranjestad, PWH

[Bonaire]

Stenodontes spinibarbis: Sieben 2016: Observation .org - Dos Pos, H. Sieben

\section{Curaçao}

Stenodontes (Mallodon) spinibarbis: Gilmour 1968: 87 Agricultural Station, BAB; Agricultural Station, ACJB; Groot Piscadera, PWH; Hato, ADR; Jongbloed, BJ; Julianadorp, Y

Mallodon spinibarbe: This study - Jongbloed, BJ; Suffisant, RK

\section{Solenoptera chalumeaui Villiers, 1979a: 23}

St. Martin

Solenoptera chalumeaui Villiers, 1979a: 23 - Pic Paradis, FC

Solenoptera chalumeaui: Villiers 1980b: 148 - same as above

Solenoptera chalumeaui: Galileo \& Martins 1993: 433

- no locality, HER

Solenoptera chalumeaui: Chalumeau \& Touroult 2005: 59 - Pic Paradis, FC; Concordia, DE

Solenoptera chalumeaui: Touroult 2019b - no locality, PHD; no locality, M. Yokoyama

Endemic to St. Martin.

Subfamily CERAMBYCINAE Latreille, 1802: 211

Achryson quadrimaculatum (Fabricius, 1792a): 328 Aruba

Achryson ornatipenne: Gilmour 1968: 106 - Plantage Fontein, HJMG; no locality, JZ; Eagle Petroleum Company, W of Oranjestad, PWH; no locality, RHC

\section{Curaçao}

Achryson quadrimaculatum: This study - Suffisant, RK

New species record for Curaçao. For the year of publication see Evenhuis (1997).

\section{Achryson surinamum (Linnaeus, 1767): 632} Aruba

Achryson surinamum: Gilmour 1968: 104 - Oranjestad, HJMG; Eagle Petroleum Company, W. of Oranjestad, PWH; Bubali, NW of Oranjestad, PWH

\section{Bonaire}

Achryson surinamum: Gilmour 1968: 104 - Kralendijk, Hotel Zeebad, PWH; no locality, RHC; no locality, ESPK

\section{Curaçao}

Achryson surinamum: Gilmour 1968: 104 - hofje Porto Marie, HJMG; hofje Sint Kruis, HJMG; hofje Savonet, HJMG; Jongbloed, BJ; no locality, RHC; Willemstad, RHC; Piscadera Baai, CARMABI, RHC; no locality, BJ; Piscadera Baai, CARMABI, PWH; no locality, Heylaerts

Achryson surinamum: This study - Suffisant, RK

\section{St. Martin}

Achryson surinamum: Villiers 1980a: 271 - Cul-de-Sac, $\mathrm{AD}$; no locality, JHPB

Achryson surinamum: Chalumeau \& Touroult 2005: 74 - Cul-de-Sac, no leg.; Concordia, DE

Achryson surinamum: Touroult $2019 \mathrm{~b}$ - no locality, M. Yokoyama; no locality, EP

\section{Anelaphus cinereus (Olivier, 1800a): 69}

[Curaçao]

Anelaphus subtropicus: Gilmour 1968: 133 -, BJ

The presence of this species on Curaçao is questionable. According to Monné (2020a) Anelaphus cinereus is known elsewhere from Florida, Cuba, Hispaniola, Jamaica, Bahamas, Virgin Islands, Cayman Islands, Bermudas, and Puerto Rico. Ivie (1985) synonymised Anoplium subtropicus Casey, 1924: 245 with $A$. cinereus and referred several $A$. subtropicus nec Casey, 1924 auct. to $A$. nanus but did not investigate the single known specimen from Curaçao which is in DMAG. The occurrence of the latter species on Curaçao would be equally doubtful because this species would then have a similar disjunct range as $A$. cinereus. However, until the Doncaster specimen has been investigated the species cannot fully be excluded because there are at least two other longhorn beetle species with a similar range which are present on Curaçao. For the year of publication see Bousquet (2018).

Anelaphus curacaoensis Gilmour, 1968: 133 Curaçao

Anelaphus curacaoensis Gilmour, 1968: 133 - Groot Piscadera, PWH; Pasanggrahan, PWH; Mahaai, BJ; Jongbloed, BJ; Parera, Willemstad, RHC; Piscadera Baai, CARMABI, RHC; Piscadera Baai, CARMABI, PWH

Anelaphus curacaoensis: This study - Jongbloed, BJ Endemic to Curaçao.

Anelaphus nanus (Fabricius, 1792a): 300

\section{St. Martin}


Anelaphus subtropicus: Villiers 1980a: 289 - no locality, $\mathrm{JHPB}$

Anelaphus nanus: Ivie 1985: 304 - without further data

Caribbomerus attenuatus (Chevrolat, 1862): 263

\section{St. Martin}

Caribbomerus attenuatus: Chalumeau \& Touroult 2005: 110 - Pic Paradis, no leg.

Based on the distinguishing characters listed in Lingafelter (2011), Touroult (2012) referred previous records of Caribbomerus attenuatus from the Lesser Antilles to C. similis (Fisher, 1932). According to him $C$. attenuatus is only present on Cuba, Puerto Rico, the Bahamas and possibly the Virgin Islands. Peck (2016) followed him but noted that Touroult only reinvestigated specimens from Guadeloupe and not from other Lesser Antillean islands. Touroult's current opinion is that this issue is in need of further study based on more material and until then the species present on St. Martin should be considered $C$. attenuatus (Touroult in litt. 2020).

\section{Curtomerus flavus (Fabricius, 1775): 191}

\section{Aruba}

Curtomerus flavus: Gilmour 1968: 143 - no locality, RHC

\section{Bonaire}

Curtomerus flavus: Gilmour 1968: 143 - Dos Poos, HJMG

\section{Curaçao}

Curtomerus flavus: Gilmour 1968: 143 - hofje Porto Marie, HJMG; hofje St. Kruis, HJMG; Plantersrust, GJHM; Hato, ADR; Jongbloed, BJ; Willemstad, RHC; no locality, RHC; no locality, BJ

Curtomerus flavus: This study - Suffisant, RK

\section{Saba}

Cylindera flava: Gilmour 1963a: 96 - Windwardside, RHC

\section{St. Martin}

Cylindera flava: Gilmour 1963a: 96 - Philipsburg, PWH

Curtomerus flavus: Villiers 1980a: 282 - no locality, $\mathrm{JHPB}$

Curtomerus flavus: Touroult 2019b - no locality, M. Yokoyama; no locality, EP

\section{Eburia bonairensis Gilmour, 1968: 115}

\section{Bonaire}

Eburia bonairensis Gilmour, 1968: 115 - Kralendijk, HJMG; hofje Fontein, HJMG; Dos Poos, HJMG; Kralendijk, PWH; no locality, ESPK; no locality, RHC

Eburnia (sic!) quadrimaculata: Werner 1925: 556 - no locality, AG
Eburia bonairensis: Thomas 2020: GBIF - Kralendijk, industrial mudflats, DWB

Eburia bonairensis: This study - Rincón, JKW

\section{Curaçao}

Eburia bonairensis Gilmour, 1968: 115 - Hato, ADR; Willemstad, RHC

Eburia quadrimaculata sensu Werner 1925 is probably this species. This specimen is probably the paratype in the Ernst Fuchs Collection (now in the Herbert Schmid collection, Vienna (Monné \& Monné 2006)) which Gilmour (1968) listed in his description.

Eburia decemmaculata (Fabricius, 1775): 181

[Saba]

Eburia decemmaculata: Terpstra 2013a: Observation .org - Windward Side, M. Terpstra

\section{St. Eustatius}

Eburia decemmaculata: Gilmour 1963a: 77 - Oranjestad, RHC

\section{St. Martin}

Eburia decemmaculata: Gilmour 1963a: 77 - Philipsburg, PWH; Philipsburg, RHC; Lowlands, RHC

Eburia decemmaculata: Touroult 2019b - no locality, PHD; no locality, M. Yokoyama

Two records from Nevis on iNaturalist (Hewitt 2017, 2018).

Eburia thoracica White, 1853: 92

\section{Curaçao}

Eburia thoracica: Gilmour 1968: 112-Hato, ADR; Jongbloed, BJ; Mahaai, BJ; Willemstad, RHC; Julianadorp, Y; Piscadera Baai, CARMABI, RHC; Piscadera Baai, CARMABI, LJS; Piscadera Baai, CARMABI, PWH; no locality, BJ

Eburia thoracica: Martins 1997: 81 - Piscadera Baai, no leg.

Eburia thoracica: This study - Suffisant, RK

Elaphidion conspersum Newman, 1841: 110

\section{Bonaire}

Elaphidion conspersum: Villiers 1980a: 285 - without further data

\section{Curaçao}

Elaphidion conspersum: Gilmour 1968: 127 - Cas Cora, Agricultural Station, ACJB; Piscadera Baai, CARMABI, PWH

\section{St. Martin}

Elaphidion spinicorne: Gilmour 1963a: 81 - Philipsburg, PWH; Philipsburg, RHC

Elaphidion conspersum: Villiers 1980a: 285 - Baie Nettlé, JHPB

Elaphidion spinicorne: Chalumeau \& Touroult 2005: 94

- Cul-de-Sac, AD 
Elaphidion conspersum: Chalumeau \& Touroult 2005: 96 - Baie Nettlé, no leg.; Mont Vernon, DE Ivie (1985) is here followed in assigning nonJamaican Elaphidion spinicorne records to this species.

\section{Elaphidion curacaoae Gilmour, 1968: 128}

\section{Curaçao}

Elaphidion curacaoae Gilmour, 1968: 128 - Piscadera

Baai, CARMABI, PWH

Endemic to Curaçao.

Elaphidion glabratum (Fabricius, 1792a): 295

\section{Saba}

Elaphidion glabratum: Chalumeau \& Touroult 2005: 101 - no locality, DE

\section{St. Eustatius}

Elaphidion cobbeni Gilmour, 1963a: 81 - no locality, RHC

Elaphidion glabratum: Villiers 1979b: 96 - same as above

Elaphidion glabratum: This study - Botanical Garden, $\mathrm{KB}$

\section{St. Martin}

Elaphidion hummelincki Gilmour, 1963a: 84 - Philipsburg, PWH

Elaphidion glabratum: Villiers 1979b: 96 - same as above

Elaphidion glabratum: Villiers 1980a: 287 - Terre-Basse, P. Pinchon; l'Orient, P. Pinchon; without further data, ex col. Bates)

Elaphidion glabratum: Chalumeau \& Touroult 2005: 101 - Philipsburg, no leg.

Elaphidion glabratum: Touroult $2019 \mathrm{~b}$ - no locality, M. Yokoyama

\section{Elaphidion irroratum (Linnaeus, 1767): 633}

\section{[Aruba]}

Elaphidion irroratum: Oversteegen 2019: iNaturalist without further details

\section{Bonaire}

Elaphidion irroratum: Gilmour 1968: 125 - Rincón, HJMG; hofje Fontein, HJMG; Dos Poos, HJMG; Kralendijk, PWH; no locality, RHC; no locality, ESPK

Elaphidion irroratum: This study - Rincón, JKW

\section{Curaçao}

Elaphidion irroratum: Gilmour 1968: 125 - hofje St. Kruis, HJMG; Willemstad, VHB; St. Thomas College, Hoogstraat, Willemstad, WAJH; Museum, Willemstad, 1949, PWH; Jongbloed, BJ; Willemstad, RHC; Piscadera Baai, CARMABI, RHC; Piscadera Baai, CARMABI, JHS; no locality, BJ; Piscadera Baai, CARMABI, PWH

Elaphidion irroratum: This study - Suffisant, RK

St. Martin
Elaphidion insulare Gilmour 1963a: 81 (nec Newman, 1840: 27) - Philipsburg, PWH

Elaphidion insulare sensu Gilmour 1963a (pro parte): Villiers, 1979b: 97 - without further data

Elaphidion irroratum debieni Chalumeau \& Touroult, 2004: 754 - Cul de Sac, FC

Elaphidion irroratum debieni: Chalumeau \& Touroult 2005: 98 - Cul-de-Sac, DE

\section{Heterachthes sablensis Blatchley, 1920: 68}

\section{Aruba}

Heterachthes arubae: Gilmour, 1968: 146 - no locality, RHC

Not endemic to Aruba as listed by Debrot (2006) (as H. arubae).

Methia necydalea (Fabricius, 1798): 148

[Saba]

Methia necydalea: Touroult 2012: 83 - without further data

\section{St. Eustatius}

Methia necydalea: Gilmour 1963a: 96 - no locality, RHC

Methia necydalea: This study - Oranjestad, EOC; Botanical Garden, KB; The Quill, KB; The Quill, AJW; The Quill, JTS

\section{St. Martin}

Methia necydalea: Villiers 1980a: 269 - Cul-de-Sac, AD Methia necydalea: Philips 1990: 136 - Cul-de-Sac, AD; Marigot, FC; Griselle, FC

Methia necydalea: Philips \& Ivie 1998: 72 - same as above

Methia necydalea: Touroult 2019b - no locality, M. Yokoyama

Touroult (2012, Annexe I), followed by Peck (2016), was the first to list Saba for this species. However, the entry is not in bold as are the other new island records in his table. Moreover, he did not list St. Kitts (the adjoining column in the table), an island record from Frigate Bay first mentioned by Chalumeau \& Touroult (2005). The latter paper is listed in the references section by Touroult (2012). Julien Touroult kindly checked his collection and there is no voucher for Saba there (Touroult 2020 in litt). Although it is certainly possible that Methia necydalea is present on Saba, this particular record is probably a typographic error and, without availability of a voucher, we have here placed this record between brackets for now.

\section{Methia trium Gilmour, 1968: 100}

\section{Aruba}

Methia trium Gilmour, 1968: 100 - Oranjestad, HJMG; Eagle Petroleum Company, PWH; Bubali, PWH 


\section{Bonaire}

Methia trium Gilmour, 1968: 100 - hofje Fontein, HJMG; Dos Poos, HJMG; Kralendijk, PWH; no locality, ESPK; no locality, RHC

\section{Curaçao}

Methia trium Gilmour, 1968: 100 - hofje Porto Marie, HJMG; hofje Sint Kruis, HJMG; hofje Savonet, HJMG; Jongbloed, BJ; Willemstad, RHC; Julianadorp, RHC; CARMABI, RHC; no locality, RHC; Cas Cora, no leg.; Piscadera Baai, CARMABI, PWH; no locality, BJ

Methia trium: Philips 1990: 29 - CARMABI, Piscadera Baai, PWH; Coral Specht, $3 \mathrm{~km}$ E. Willemstad, WES \& JMS; Ascencion, WES \& JMS

Methia trium: Philips \& Ivie 1998: 69 - Piscadera, MRDP; CARMABI, Piscadera Baai, PWH; Coral Specht, $3 \mathrm{~km}$ E. Willemstad, WES \& JMS; Ascencion, WES \& JMS

Methia trium: This study - Jongbloed, BJ; Suffisant, RK

Mionochroma vittatum (Fabricius, 1775): 166 Curaçao

Callichroma (Mionochroma) vittatum: Gilmour 1968: 148 - Jongbloed, BJ; Willemstad, RHC; Willemstad, St. Thomas school, WAJH; Piscadera Baai, CARMABI, RHC; Patatentuin, Sta. Martha, ACJB

\section{Neoclytus araneiformis (Olivier, 1800a): 61}

\section{Saba}

Neoclytus araneiformis: Gilmour 1963a: 96 - Windwardside, RHC

Neoclytus araneiformis: Chalumeau \& Touroult 2005: 118 - no locality, DE

For the year of publication see Bousquet (2018).

\section{Neocompsa cylindricollis (Fabricius, 1798): 146}

\section{Saba}

Neocompsa cylindricollis: Chalumeau \& Touroult 2005: 109 - St. Johns, no leg.

\section{St. Eustatius}

Heterachthes quadrimaculatus: Gilmour 1963a: 93 - no locality, RHC

Neocompsa cylindricollis: This study - Oranjestad, EOC St. Martin

Neocompsa quadrimaculata: Villiers 1980a: 291 - no locality, JHPB

Neocompsa cylindricollis: Chalumeau \& Touroult 2005: 109 - Pic Paradis, no leg.; Concordia, DE

There are records from Nevis and Anguilla on iNaturalist (Hewitt 2017, 2019, Bourque 2019).

Nesanoplium puberulum (Fleutiaux \& Sallé, 1890): 464

\section{St. Eustatius}

Nesanoplium puberulum: This study - The Quill, JTS

New species record for St. Eustatius. Collected from a Malaise trap.

\section{Oxymerus aculeatus Dupont, 1838: 38}

\section{Aruba}

Oxymerus lebasi: Gilmour 1968: 118 - Solito, PWH; Bubali, PWH; no locality, RHC

Oxymerus aculeatus lebasi: Hüdepohl 1979: 23 - San

Nicolas, JGB

Curaçao

Oxymerus lebasi: Gilmour 1968: 118 - Piscadera Baai, CARMABI, RHC; Piscadera Baai, CARMABI, BJ

Oxymerus aculeatus lebasi: Hüdepohl 1979: 23 Wellenstad [= probably Willemstad], no leg.

Oxymerus aculeatus: This study - Jongbloed, BJ

\section{St. Martin}

Oxymerus aculeatus lebasi: Touroult 2019b - no locality, M. Yokoyama; no locality, EP

Oxymerus aculeatus lebasi: greensxm 2019 - îlet de Pinel, no leg.

Listed and photographed by Yokoyama (2013) and shown as present with reference to Yokoyama on the website of the French l'Inventaire National du Patrimoine Naturel (INPN 2020) for St. Martin.

Stizocera curacaoae Gilmour, 1968: 139

\section{Curaçao}

Stizocera curacaoae Gilmour, 1968: 139 - Jongbloed, BJ; Willemstad, RHC; Piscadera Baai, CARMABI, PWH

Stizocera curacaoae: This study - Suffisant, RK

Not endemic to Curaçao as mentioned by Debrot (2006). This species is also present in Colombia (Martins 2005).

Stizocera insolita Gilmour, 1968: 141

\section{Curaçao}

Stizocera insolita Gilmour, 1968: 141 - no locality, BJ

Stizocera insolita: This study - Suffisant, RK

Endemic to Curaçao

Trachyderes succinctus (Linnaeus, 1758): 391

\section{St. Martin}

Trachyderes succinctus: Villiers 1980a: 304 - no locality, JHPB

Trachyderes succinctus: Hüdepohl 1985: 109 - without further data

Trachyderes succinctus succinctus: Touroult 2019b - no locality, M. Yokoyama

Also present on St. Kitts (UPRM 2020), an island not listed by Peck $(2011,2016)$. There are also two records from Anguilla on iNaturalist (Mlodinow 2017, Parles 2019). 
Subfamily LAMIINAE Latreille, 1825: 401

Amniscus praemorsus (Fabricius, 1792a): 275 St. Martin

Leptostyloides praemorsus: Villiers 1980c: 571 - without further data

Amniscus praemorsus: Chalumeau \& Touroult 2005: 180 - Philipsburg, PWH; Pic Paradis, no leg.; Concordia, DE

Amniscus praemorsus: Touroult 2019b - no locality, M. Yokoyama

Amniscus similis (Gahan, 1895): 136

Saba

Leptostyloides turbidus Gilmour, 1963b: 63 - Windwardside, RHC

\section{St. Eustatius}

Leptostyloides turbidus Gilmour, 1963b: 63 - no locality, RHC

Leptostyloides similis: Villiers 1980d: 91 - same as above

Amniscus similis: This study - Botanical Garden, KB; Oranjestad, EOC

Desmiphora hirticollis (Olivier, 1800b): 11

\section{Curaçao}

Desmiphora hirticollis: Gilmour 1968: 151 - Willemstad, 1956, RHC; Piscadera Baai, CARMABI, RHC; Piscadera Baai, CARMABI, PWH; Julianadorp, Y; no locality, RHC; no locality, BJ

For the year of publication see Bousquet (2018).

Dorcasta dasycera (Erichson, 1849): 574

Aruba

Dorcasta dasycera: Gilmour 1968: 150 - no locality, RHC

For the year of publication see Bousquet (2016). Bezark et al. (2018) recently revised Dorcasta but they did not mention the southern Antilles as part of the range of this species.

Ecyrus hirtipes Gahan, 1895: 127

\section{Saba}

Ecyrus hirtipes: Touroult 2012: 84 - without further data

\section{St. Eustatius}

Ecyrus hirtipes: This study - inland from Corre Corre Bay, AJW; Welfare Road, THB

New species record for St. Eustatius.

\section{Estoloides perforata (Bates, 1872): 200 \\ Curaçao}

Estoloides perforata: Gilmour 1968: 153 - Jongbloed, BJ; Willemstad, RHC; Piscadera Baai, CARMABI, RHC
Lagocheirus araneiformis (Linnaeus, 1767): 625 Aruba

Lagocheirus araneiformis curacaoensis Gilmour, 1968: 158 - Eagle Petroleum Company, W of Oranjestad, PWH; Oranjestad, JGB; Savaneta, JGB; Bubali, PWH

\section{Bonaire}

Lagochirus (sic!) sp. aff. obsoletus: Werner 1925: 556 no locality, AG

Lagocheirus araneiformis curacaoensis Gilmour, 1968: 158 - Kralendijk, PWH; no locality, RHC

\section{Curaçao}

Lagocheirus araneiformis curacaoensis Gilmour, 1968:

158 - St. Kruis, hofje, HJMG; hofje Savonet, HJMG;

Willemstad, BJ; Jongbloed, BJ; Emmastad, RF; Willemstad, RHC; Piscadera Baai, CARMABI, PWH; no locality, de Wolff

Lagocheirus araneiformis: This study - Suffisant, RK

[Saba]

Lagocheirus araneiformis guadeloupensis: Touroult 2012: 85 - without further data

\section{St. Eustatius}

Lagocheirus araneiformis guadeloupensis: Gilmour 1963b: 58 - Oranjestad, PWH; no locality, RHC

\section{St. Martin}

Lagocheirus araneiformis guadeloupensis: Gilmour 1963b: 58 - Philipsburg, PWH; no locality, RHC

Lagochirus (sic!) sp. aff. obsoletus Werner 1925 is probably this species. Touroult (2012, Annexe I), followed by Peck (2016), was the first to list Saba for this species. However, the entry is not in bold as are the other new island records in his table and he does not list St. Eustatius in the adjoining column in the table. Julien Touroult checked his collection and there is no voucher for Saba there (Touroult 2020 in litt). Although it is certainly possible that Lagocheirus araneiformis occurs on Saba, this particular record is probably a typographic error and we have here placed this record between brackets for now.

Leptostylopsis argentatus (Jacquelin du Val, 1857): 273

\section{Curaçao}

Leptostylopsis argentatus: Gilmour 1968: 160 - Piscadera Baai, CARMABI, RHC

Leptostylopsis argentatus: This study - Suffisant, RK Curaçao lies far outside the range of this species which occurs from southern Florida to Georgia, Cuba, Hispaniola, Puerto Rico, Bahamas, Jamaica and Cayman Islands (Monné 2020b). Its presence on Curaçao is possibly the result of a recent introduction. See also Urgleptes cobbeni below. 
Lithargyrus guadeloupensis (Villiers, 1980d): 89 Saba

Lithargyrus guadeloupensis: Touroult 2012: 85 - without further data

Nealcidion socium (Gahan, 1895): 131

Curaçao

Nealcidion socium: This study - Suffisant, RK

New species record for Curaçao.

Nyssodrysina haldemani (LeConte, 1852b): 173

Curaçao

Nyssodrysina haldemani: Gilmour 1968: 162 - no locality, BJ

Psapharochrus circumflexus (Jacquelin du Val, 1857): 270

Curaçao

Acanthoderes (Psapharochrus) circumflexa: Gilmour 1968: 154 - Emmastad, RF; no locality, BJ; Piscadera Baai, CARMABI, PWH

Psapharochrus circumflexus: This study - Suffisant, RK

Styloleptus inermis (Fabricius, 1801a): 293

St. Eustatius

Caribbeana hebes Gilmour, 1963a: 98 - no locality, RHC

Styloleptus inermis: Ivie 1985: 315 - same as above

Styloleptus posticalis (Gahan, 1895): 133

\section{Saba}

Styloleptus posticalis: Touroult 2012: 85 - without further data

\section{Urgleptes cobbeni Gilmour, 1963b: 85}

Bonaire

Urgleptes cobbeni: Gilmour 1968: 169 - no locality, ESPK; no locality, RHC

\section{Curaçao}

Urgleptes cobbeni: Gilmour 1968: 169 - Jongbloed, BJ; Piscadera Baai, CARMABI, RHC; Julianadorp, RHC

Urgleptes cobbeni: This study - Suffisant, RK

\section{Saba}

Urgleptes cobbeni Gilmour, 1963b: 85 - Windwardside, RHC

\section{St. Eustatius}

Urgleptes cobbeni Gilmour, 1963b: 85 - no locality, RHC

Urgleptes cobbeni: This study - no locality, THB

St. Martin

Urgleptes cobbeni: Chalumeau 1983c: 233 - Pic Paradis, FC

Urgleptes cobbeni: Touroult 2019b - no locality, EP
Chalumeau \& Touroult (2005) listed Urgleptes guadeloupensis as the only Urgleptes species present on Curaçao and suspected the Bonaire and Curaçao records of $U$. cobbeni to be either erroneous or the result of a recent introduction. In light of the fact that $U$. cobbeni has been collected by several collectors from at least 1957 until 1983 the latter could be the right explanation. However, hitherto the first author has seen 13 specimens of $U$. cobbeni and no U. guadeloupensis from Curaçao. The latter species is only known from a single specimen of the $\mathrm{ABC}$ islands (see below).

Urgleptes guadeloupensis (Fleutiaux \& Sallé, 1890): 472

\section{Curaçao}

Urgleptes guadeloupensis: Gilmour 1968: 166 - hofje Sint Kruis, HJMG

Cazier \& Lacey (1952) is the only paper that includes Antigua in the range of this species but without reference to a specimen or a publication. Their listing might belong to one of the later described Urgleptes species. The reported range and validity of the various Urgleptes species in the Antilles seems to be unclear at the least. Chalumeau \& Touroult (2005) not only suspect the Bonaire and Curaçao records of $U$. cobbeni to be either erroneous or the result of a recent introduction, they also suspect $U$. clarkei Chemsak, 1966 to be synonymous with $U$. sandersoni Gilmour, 1963b. Urgleptes clarkei was described by Chemsak based on specimens collected on the Virgin Islands and Antigua. Chemsak (1966) did not mention any of Gilmour's papers in his description and did not seem to have compared his specimens with the species described by Gilmour (1963b, 1968). Gilmour (1968) questioned the presence of $U$. clarkei on Antigua and, in light of the disjunct distribution and the fact that Peck (2016) recently added Antigua to the range of $U$. cobbeni, might prove to be right. A revision of Antillean Urgleptes would be highly desirable.

\section{Urgleptes hummelincki Gilmour, 1968: 171 \\ Aruba}

Urgleptes hummelincki Gilmour, 1968: 171 - Bubali, NW of Oranjestad, PWH

Endemic to Aruba.

Family BRUCHIDAE Latreille, 1802: 192

See also the remark below under the family Chrysomelidae.

Subfamily PACHYMERINAE Bridwell, 1929: 142 
Caryedon gonagra (Fabricius, 1798): 159

\section{Curaçao}

Caryedon gonagra: Davey 1958: 393 - no locality, FJS

Caryoborus gonagra: Wiebes 1961: 234 - imported into The Netherlands from Willemstad, A.F.C. Gogelein Caryedon serratus: Bottimer 1968: 1037 - imported into the USA in 1953 and 1963, no leg.

Introduced. Often confused with the groundnut pest Caryedon serratus (Olivier, 1790): 199. The species are very similar but can be distinguished by the structure of the male genitalia (Delobel et al. 2003).

Subfamily AMBLYCERINAE Bridwell, 1932: 103

\section{Amblycerus dispar (Sharp, 1885): 494 \\ Curaçao}

Amblycerus dispar: Ribeiro-Costa et al. 2018: 506 Hato, BM

Amblycerus dispar: dos Santos \& Ribeiro-Costa 2019: 111 - no locality, T.E. Rogers; Hato, BM

Amblycerus schwarzi Kingsolver, 1970: 477 Curaçao

Amblycerus schwarzi Kingsolver, 1970: 477 - imported into the USA, Plant Quarantine interception, Washington D.C., H.L. Sanford

Zabrotes achiote Romero \& Johnson, 2000: 227 [Aruba]

Zabrotes achiote Romero \& Johnson, 2000: 227 - "BONAIRE: Aruba", JMC

\section{[Bonaire]}

Zabrotes achiote Romero \& Johnson, 2000: 227 - "BONAIRE: Aruba”, JMC

\section{Curaçao}

Zabrotes achiote Romero \& Johnson, 2000: 227 - Zapateer, JMC

The distribution of this species on the $\mathrm{ABC}$ islands is not completely clear. It possibly occurs on all three islands but Romero \& Johnson (2000) and Romero Nápoles (2018) listed the enigmatic locality "BONAIRE: Aruba." There is no locality called Aruba on Bonaire. In another paper the same authors listed Zabrotes achiote only for the island Bonaire (Romero \& Johnson 2004) and on GBIF the locality is listed as "Aruba" and the country as "Bonaire, Sint Eustatius and Saba" (Romero Nápoles 2018).

Subfamily BRUCHINAE Latreille, 1802: 192

Acanthoscelides Schilsky, 1905: C

\section{St. Eustatius}

Acanthoscelides species: This study - Oranjestad, EOC
Acanthoscelides desmanthi Johnson, 1977: 64

\section{Curaçao}

Acanthoscelides desmanthi: Johnson 1990: 364 - without

further data

\section{St. Eustatius}

Acanthoscelides desmanthi: Johnson 1990: 364 - without further data

Acanthoscelides difficilis (Sharp, 1885): 452

\section{St. Eustatius}

Acanthoscelides difficilis: Johnson 1990: 369 - without further data

Acanthoscelides diffcilis: This study - Oranjestad, EOC

Acanthoscelides flavescens (Fåhraeus, 1839): 32

\section{Aruba}

Acanthoscelides ochraceicolor: Kingsolver 1969: 53 - no locality, JMC

Acanthoscelides flavescens: Johnson 1990: 384 - without further data

\section{Bonaire}

Acanthoscelides ochraceicolor: Kingsolver 1969: 53 - N. Washington, JMC

Acanthoscelides flavescens: Johnson 1990: 384 - without further data

Curaçao

Acanthoscelides flavescens: Johnson 1990: 384 - without further data

Acanthoscelides indigoferestes Johnson, 1983: 100

\section{[St. Eustatius]}

Acanthoscelides indigoferestes: Johnson 1990: 399 - without further data

Johnson (1990) is the first to include St. Eustatius (as St. Estatius) in the range of this species but it is unclear on which basis. This species is elsewhere known from Panama, Colombia and Venezuela, and from an interception by the United States Department of Agriculture of material originating from the Dominican Republic (Johnson 1990).

Acanthoscelides macrophthalmus (Schaeffer, 1907): 300

\section{Bonaire}

Acanthoscelides macrophthalmus: Beenen in litt. 2017 Rincón, JKW

New species record for Bonaire.

\section{Acanthoscelides pertinax (Sharp, 1885): 453}

\section{Curaçao}

Acanthoscelides pertinax: Johnson 1990: 444 - without further data 
Acanthoscelides rufovittatus (Schaeffer, 1907): 303 Curaçao

Acanthoscelides rufovittatus: Johnson 1990: 462 - without further data

Acanthoscelides zeteki Kingsolver, 1969: 50 Curaçao

Acanthoscelides zeteki Kingsolver, 1969: 50 - imported into the USA, U.S. Department of Agriculture Plant Quarantine

Callosobruchus maculatus (Fabricius, 1775): 65

[St. Martin]

Callosobruchus maculatus: Yokoyama 2013: 82 - without further data

Listed and photographed by Yokoyama (2013) and shown as present with reference to Yokoyama on the website of the INPN (2020) for St. Martin. It is not clear if vouchers are available.

Megacerus tricolor (Suffrian, 1870): 157

\section{Curaçao}

Megacerus tricolor: Terán \& Kingsolver 1992: 23 Schottgatwee [=Schottegatweg], JMC

Mimosestes insularis Kingsolver \& Johnson, 1978: 35

\section{Curaçao}

Mimosestes insularis Kingsolver \& Johnson, 1978: 35 Damacar, JMC

Mimosestes mimosae (Fabricius, 1781): 76

\section{Aruba}

Mimosestes mimosae: Kingsolver \& Johnson 1978: 42 imported into the USA, Hoboken Plant Quarantine, New Jersey

\section{Bonaire}

Mimosestes mimosae Beenen in litt. 2017 - Rincón, JKW

\section{Curaçao}

[Mimosestes mimosae: Kingsolver \& Johnson 1978: 42 without further data]

Mimosestes mimosae: Fägerström 2020: GBIF - without further data

New species record for Bonaire. Kingsolver \& Johnson (1978) listed Curaçao but only in the distribution of the species. They did not list a specimen for the island whereas they did so for Aruba.

\section{Stator cearanus (Pic, 1930): 12}

\section{Curaçao}

Stator cearanus: Kingsolver 1972: 225 - Schottgatwee [=Schottegatweg], JMC

Johnson (1995) synonymised Stator cearanus with S. limbatus (Horn, 1873b): 326 but Kingsolver et al. (2017) later considered it a valid species again.

Stator sordidus (Horn, 1873b): 326

Curaçao

Stator sordidus: Escobar-Domínguez et al. 2018: 13 without further data

Escobar-Domínguez et al. 2018 listed this species for Curaçao but only in the distribution of the species and without further details. We have not been able to find an earlier record for Curaçao.

Family CHRYSOMELIDAE Latreille, 1802: 220

Ivie et al. (2009) listed eight species of this family from Saba. The present paper contains information on four which means that at least four, as yet unpublished, other species are present on the island. It is unclear if the family Chrysomelidae in the poster of Ivie et al. (2009) includes the Bruchidae as a family or a subfamily.

Subfamily CASSIDINAE Gyllenhal, 1813: 434

Agenysa guianiensis (Boheman, 1856): 36

Curaçao

Agenysa guianiensis: Viana 1968: 83 - no locality, CTE

Chalepus sanguinicollis (Linnaeus, 1771): 550

\section{[St. Martin]}

Chalepus sanguinicollis: Yokoyama 2013: 82 - without further data

Listed and photographed by Yokoyama (2013) and shown as present with reference to Yokoyama on the website of the INPN (2020) for St. Martin. It is not clear if vouchers are available. UPRM (2020) lists two specimens in EPRL from St. Kitts, an island not listed by Peck (2011, 2016).

Charidotella sexpunctata (Fabricius, 1781): 109 [Saba]

Charidotella sexpunctata: Terpstra 2013a: Observation. org - Mount Scenery, M. Terpstra

[St. Martin]

Charidotella sexpunctata: Yokoyama 2010: 80 - without further data

Listed and photographed by Yokoyama (2010) for St. Martin. It is not clear if vouchers are available.

Chelymorpha multipunctata (Olivier, 1791b): 384

[Saba]

Chelymorpha cribraria: Terpstra 2013a: Observation .org - Mount Scenery, M. Terpstra 
Chelymorpha cribraria: Terpstra 2013b: iNaturalist same as above

Chelymorpha cribraria: van der Beek 2018: Observation.org - Mount Scenery, J. van der Beek

Cassidinae species: DeMaster 2018: iNaturalist Windward Side, N. DeMaster

Chelymorpha cribraria: Haber 2019: iNaturalist Windward Side, E. Haber

[St. Martin]

Chelymorpha cribraria: Yokoyama 2013: 82 - without further data

All records are listed as Chelymorpha cribraria. However, Sekerka \& Barclay (2014) revised the Fabrician Cassidinae types present in the Natural History Museum, London. They found that the two types of Cassida cribraria Fabricius, 1775: 90 do agree with the original description but are conspecific with Ch. cassidea (Fabricius, 1775): 82 and not with $C h$. cribraria as defined and used since Boheman (1854). As a result Ch. cribraria auct. loses its name and must be replaced by the next available name Chelymorpha multipunctata (Olivier, 1791b).

For the year of publication see Bousquet (2016). Olivier (1791b) in his "Encyclopédie méthodique" described Cassida multipunctata from specimens donated by de Badier from "Guadeloupe". Later, when treating this species in his "Entomologie" he only mentioned "Guyane française" as its patria (Olivier 1808a: 957). It is not clear whether the latter is a correction of the terra typica or if Olivier (1808a) forgot to mention Guadeloupe. Barthélemy de Badier (1740?-1789) lived for several years in Guadeloupe but also received specimens from other French territories in the Caribbean and South America (Cupello 2018). As Olivier (1808a) referred to the original description and both descriptions closely match, he intended to treat the same species, not a different one erroneously under the same name. The latter could be concluded from some sources giving 1808 as the year of publication of this species. According to Staines \& Whittington (2003), who indeed use the year 1808 , two syntypes are in the Royal Museum of Scotland.

Listed and photographed by Yokoyama (2013) and shown as present with reference to Yokoyama on the website of the INPN (2020) for St. Martin. It is not clear if vouchers are available.

Hilarocassis exclamationis (Linnaeus, 1767): 577 [Curaçao]

Hilarocassis exclamationis: Benschop 2010: Observation.org - Christoffel Park, A. Benschop

Subfamily GALERUCINAE Latreille, 1802: 228
Altica occidentalis Suffrian, 1868: 197

\section{[St. Martin]}

Altica cf. occidentalis: Yokoyama 2010: 81 - without further data

Probably based on a photo, Yokoyama (2010) provisionally listed this species for St. Martin. Altica occidentalis is known elsewhere in the Caribbean area from Antigua, Barbados, the Cayman Islands, Cuba, Dominica, Grenada, Guadeloupe, Guana, Hispaniola, Jamaica, Martinique, Puerto Rico, St. Croix, St. Lucia, St. Vincent, Vieques and the Virgin Islands (Peck 2016). Clark et al. (2013) suspect that specimens from the southern islands belong to a different species.

Chaetocnema minutissima (Suffrian, 1868): 220

\section{Curaçao}

Chaetocnema minutissima: Bechyné 1955: 183 - without further data

\section{Disonycha spilotrachela Blake, 1928: 96}

[Saba]

Disonycha spilotrachela: Haber 2019: iNaturalist - Zions Hill, E. Haber

\section{[St. Martin]}

Disonycha spilotrachela: Yokoyama 2013: 82 - without further data

Listed and photographed by Yokoyama (2013) and shown as present with reference to Yokoyama on the website of the INPN (2020) for St. Martin. It is not clear if vouchers are available. Numerous records from Nevis on iNaturalist (for instance Hewitt 2019).

Omophoita albicollis (Fabricius, 1787b): 76

[Saba]

Omophoita albicollis: Boeken 2010: photo sent to the first author

Omophoita albicollis: Terpstra 2013a: Observation .org - Mount Scenery, M. Terpstra

Omophoita albicollis: Terpstra 2013b: iNaturalist - same as above

\section{[St. Martin]}

Omophoita albicollis: Yokoyama 2013: 82 - without further data

Listed and photographed by Yokoyama (2013) and shown as present with reference to Yokoyama on the website of the INPN (2020) for St. Martin. It is not clear if vouchers are available. Listed by Questel (2014) and shown as present with reference to Questel on the website of the INPN (2020) for St. Barthélemy. It is not clear if vouchers are available. Also two records for Nevis on iNaturalist (Hewitt 2018, 2019). 
Yingaresca spiloptera (Blake, 1959): 180

[Curaçao]

Galerucella spiloptera Blake, 1959: 180 - collected in Miami, USA in a plane from Curaçao, via Jamaica, W.F. Buren

Yingaresca spiloptera: Wilcox 1971: 106 - "Curaçao or Jamaica"

Galerucella spiloptera: Orrell 2020: GBIF - same as above

\section{Subfamily EUMOLPINAE Hope, 1840: 162}

Colaspis musae Bechyné, 1950: 71

Bonaire

Colaspis musae: Beenen in litt. 2017 - Karpata, G. den Hollander

New species record for Bonaire.

\section{Subfamily CRYPTOCEPHALINAE Gyllenhal,} 1813: 582

\section{Cryptocephalus krugi Weise, 1885: 148}

\section{St. Eustatius}

Cryptocephalus krugi: This study - The Quill, JTS

[St. Martin]

Cryptocephalus krugi: Yokoyama 2013: 82 - without further data

New species record for St. Eustatius and the Lesser Antilles. Hitherto known from Puerto Rico and the Virgin Islands (Weise 1885, Wolcott 1951, Valentine \& Ivie 2005). Also listed and photographed by Yokoyama (2013) and shown as present with reference to Yokoyama on the website of the INPN (2020) for St. Martin. It is not clear if vouchers are available. Listed by Questel (2014) and shown as present with reference to Questel on the website of the INPN (2020) for St. Barthélemy. It is not clear if vouchers are available.

Family ANTHRIBIDAE Billberg, 1820a: 39 Ivie et al. (2009) listed three, as yet unpublished, species of this family from Saba.

Family BRENTIDAE Billberg, 1820a: 40

Subfamily TRACHELIZINAE Lacordaire, 1865: 417

\section{Nemocephalus monilis (Fabricius, 1787b): 95} Saba

Nemocephalus monilis: Gillett \& Gillett 2019: 873 - Saba University, The Bottom, MPTG; English Quarter, Windward Side, MPTG; Lower Mountain Road, MPTG; Upper Hells Gate, MPTG; Upper Mountain Road, MPTG; Crispeen, St. Johns, MPTG; Hospital, The Bottom, MPTG; Booby Hill, MPTG;
The Level, MPTG; Lower Hells Gate, MPTG; Saba University School of Medicine, The Bottom, MPTG

\section{St. Eustatius}

Nemocephalus monilis: This study - The Quill, KB; The Quill, AJW; Oranjestad, THB

\section{St. Martin}

Nemocephalus monilis: Mantilleri 2014: 114 - Pic Paradis, BLC; no locality, SAM

New species record for St. Eustatius. Collected at light, from under bark and from vegetation.

Subfamily CYLADINAE Schönherr, 1823: column 1137

Cylas formicarius (Fabricius, 1798): 174

[Curaçao]

Cylas formicarius elegantulus: Sherman \& Tamashiro 1954: 5 - without further data

Cylas formicarius: van Buurt \& Debrot 2012: 34 - without further data

[St. Eustatius]

Cylas formicarius: Ballou 1934: 212 - without further data

Cylas formicarius: van Buurt \& Debrot 2012: 34 - without further data

\section{St. Martin}

Cylas formicarius: Bonfils \& Bart 1967: 28 - without further data

Introduced. Not mentioned for any of the islands listed above by Peck $(2011,2016)$. It is not clear if Ballou's St. Eustatius record is based on a voucher. The same applies to the records of van Buurt \& Debrot who reported that the species was introduced in Curaçao in circa 1990. Sherman \& Tamashiro (1954) reported it from that island as early as 1954 . St. Eustatius is also listed by Denon \& Mauléon (2004: 14) and Hagstrum \& Subramanyam (2009: 70). Recorded for Anguilla (Ballou 1934: 212, Denon \& Mauléon 2004: 14) and Antigua (Hagstrum \& Subramanyam 2009: $70)$, but all without reference to vouchers.

Subfamily APIONINAE Schönherr, 1823: column 1136

Apion pilosum Gyllenhal, 1833: 258

\section{St. Eustatius}

Apion pilosum Gyllenhal, 1833: 258 - no locality, JEF

Not listed by Blackwelder (1947), Kissinger (1974) or Peck $(2011,2016)$. As far as we are aware the name is only mentioned in Gemminger \& von Harold (1871), Wagner (1910, 1913), in Sherborne's Index Animalium (1929) and in the supplement to the "Annotated checklist of the weevils (Curculionidae sensu lato) of North America, Central America, and the West Indies" 
(O'Brien \& Wibmer 1984). The current whereabouts of the type of Apion pilosum is unknown. The type was collected by Forsström and was part of the Billberg collection (Gyllenhal 1833). Billberg was a Swedish entomologist whose first collection was almost completely destroyed in a fire in 1822. Only some of the types in that collection were saved. These types are currently housed in the Schönherr collection in NHRS (Löwegren 1952). Billberg started a new collection and bought Forsström's insects from the Antilles. This collection was later deposited at BMNH via J.G. Children (Horn \& Kahle 1935, Bousquet 2016). Smith (1986) also listed material from the Billberg collection as being present in HEC.

Family CURCULIONIDAE Latreille, 1802: 195

Ivie et al. (2009) listed 70 species of this family (including Scolytinae and Platypodinae) from Saba. Just four species of Curculionidae of which two only to genus level have been identified from the island. One other species of Curculionidae has been photographed.

\section{Subfamily DRYOPHTHORINAE Schönherr,} 1825: column 588

\section{Metamasius hemipterus (Linnaeus, 1758): 377 [Saba]}

Metamasius hemipterus: Terpstra 2013a: Observation. org - Ecolodge, Mount Scenery

Rhynchophorus ferrugineus (Olivier, 1791b): 473

Aruba

Rhynchophorus ferrugineus: Roda et al. 2011: 117 without further data

Curaçao

Rhynchophorus ferrugineus: EPPO 2009: 2 - without further data

Rhynchophorus ferrugineus: Roda et al. 2011: 117 Willemstad, no leg.

Rhynchophorus ferrugineus: Fiaboe et al. 2011: 768 without further data

Introduced. In December 2008 Rhynchophorus ferrugineus was found on Curaçao for the first time for the Caribbean region (EPPO 2009). Its arrival on Curaçao is suspected to be the result of the importation of infected Phoenix palms from Egypt. Shipments of palm from Curaçao to Aruba, and lack of phytosanitary measures, have resulted in the establishment of the species on Aruba (Roda et al. 2011).

Scyphophorus acupunctatus Gyllenhal, 1838: 857 [Curaçao]

Scyphophorus acupunctatus: Ballou 1920: 10 - without further data
Reported by Ballou (1920) as attacking agave in Curaçao but there are no further reports about its existence on the island. Van Buurt \& Debrot (2012) presented a list of exotic agricultural pests which are currently present in the Dutch Caribbean. Scyphophorus acupunctatus is not on that list although it is included in the alert list in this report.

Sitophilus linearis (Herbst, 1797): 5

Curaçao

Sitophilus linearis: Anonymous 1936: 35 - imported into the USA, no leg.

Sitophilus linearis: Wiebes 1961: 234 - imported into

The Netherlands from Willemstad, A.F.C. Gogelein

St. Eustatius

Sitophilus linearis: This study - Oranjestad, RV

New species record for St. Eustatius. Collected from tamarind (Tamarindus indica) pods.

Sitophilus oryzae (Linnaeus, 1763): 12

\section{St. Eustatius}

Sitophilus oryzae: This study - Oranjestad, EOC

[St. Martin]

Sitophilus oryzae: Yokoyama 2013: 83 - without further data

New species record for St. Eustatius. Collected from the kitchen and the garden of the Caribbean Netherlands Science Institute. Also listed and photographed by Yokoyama (2013) and shown as present with reference to Yokoyama on the website of the INPN (2020) for St. Martin. It is not clear if vouchers are available.

Without a voucher and investigation of the aedeagus it is hardly possible to separate this species from Sitophilus zeamais Motschulsky, 1855: 77 (Kuschel 1961). Sitophilus zeamais is not yet known from the Antilles but, as Peck (2016) also noted, being a cosmopolitan stored products pest it could also be present in the Lesser Antilles. Listed for Antigua by Roelofs (1875: xxv). This record was included in Leng \& Mutchler (1914: 478) and Blackwelder (1947: 916) but is not in Peck $(2011,2016)$. For the page number and correct reference see Marshall (1983).

Subfamily CURCULIONINAE Latreille, 1802: 195

Anthonomus macromalus Gyllenhal, 1835a: 352

\section{St. Eustatius}

Anthonomus cf. macromalus: This study - Botanical Garden, KB

The Caribbean Anthonomus are badly in need of a modern revision. Although W.E. Clark and H.R. Burke wrote more than 30 papers in which they revised several species groups in this speciose 
genus, there is no key to these groups and a number of Caribbean species have never been investigated. Based on the keys in Hustache (1929) and Rheinheimer (2014) and the original descriptions of Anthonomus aestuans Fabricius, 1792a, A. infirmus Gyllenhal, 1835b and A. macromalus Gyllenhal, 1835a the Eustatius specimen is provisionally assigned to the latter. New provisional record for St. Eustatius. For the year of publication see Bousquet (2016).

Ceratopus Schönherr, 1843: 120

Saba

Ceratopus species: Gillett et al. 2014: 2229 - without further data

Sibinia setosa (LeConte, 1876): 218

\section{[Aruba]}

Sibinia (Microtychius) setosa: Clark 1978: 364 - "BONAIRE. Aruba", no leg.

[Bonaire]

Sibinia (Microtychius) setosa: Clark 1978: 364 - "BO-

NAIRE. Aruba", no leg.

Curaçao

Sibinia (Microtychius) setosa: Clark 1978: 364 - "Damacar" [= Damacor], no leg.; Schottgatwee [= Schottegatweg], no leg.; Zapateer, no leg.)

The distribution of this species on the $\mathrm{ABC}$ islands is not entirely clear. It probably occurs on all islands (O'Brien \& Wibmer 1982) but Clark (1978) listed the enigmatic locality "BONAIRE. Aruba”.

Subfamily BARIDINAE Schönherr, 1836: 636

Linogeraeus perscitus (Herbst, 1797): 28

Curaçao

Linogeraeus perscitus: Prena 2009: 163 - without further data

Orchidophilus aterrimus (Waterhouse, 1874): 226

Netherlands Antilles

Orchidophilus aterrimus: Prena 2008: 21 - introduced into the USA, intercepted in Miami from "Netherlands Antilles"

Introduced but it is unknown if the species has established itself in the Netherlands Antilles and, if so, on which island(s).

Subfamily CRYPTORHYNCHINAE Schönherr, 1825: column 585

\section{St. Eustatius \\ Cryptorhynchinae species: This study - The Quill, EOC}

New subfamily for St. Eustatius. Beaten from vegetation.
Parisacalles Faust, 1896: 55

St. Martin

Parisacalles species: Bonfils \& Bart 1967: 28 - without further data

Pseudomopsis Champion, 1905: 486

Saba

Pseudomopsis species: Gillett et al. 2014: 2229 - without further data

Subfamily ENTIMINAE Schönherr, 1823: column 1138

Apodrosus argentatus Wolcott, 1924: 130

\section{St. Eustatius}

Apodrosus argentatus: This study - The Quill, AJW

Beaten from Tamarindus indicus. Hitherto known from Dominican Republic, Puerto Rico, Vieques Island and St. Croix (Girón \& Franz 2010).

Artipus corycaeus Sahlberg, 1823: 22

\section{St. Eustatius}

Artipus corycaeus: Franz 2016 - no locality, STD

Diaprepes abbreviatus (Linnaeus, 1758): 386

[St. Martin]

Diaprepes abbreviatus: Yokoyama 2013: 83 - without further data

Listed and photographed by Yokoyama (2013) and shown as present with reference to Yokoyama on the website of the INPN (2020) for St. Martin. It is not clear if vouchers are available. Quoted in Myers (1931: 115) for St. Kitts and Nevis with reference to Ballou (1922). It is not clear if vouchers are available for Nevis but UPRM holds a specimen from St. Kitts (UPRM 2020), an island not listed by Peck (2011, 2016).

Diaprepes famelicus (Olivier, 1791b): 544 St. Eustatius

Diaprepes famelicus: This study - Oranjestad, THB New record for St. Eustatius. Hand catch from an abandoned urban yard.

Isodrusus curacaoensis Cortés-Hernández \& Anderson, 2019: 942

Curaçao

Isodrusus curacaoensis Cortés-Hernández \& Anderson, 2019: 942 - Christoffel National Park, L. Masner Endemic to Curaçao.

Lachnopus curvipes (Fabricius, 1787b): 113

Saba

Lachnopus curvipes: Gillett et al. 2014: 2230 - without further data 
Girón et al. (2018: 52) added Barbuda and Antigua to the range as published by Peck (2011, 2016).

Lachnopus valgus (Fabricius, 1775): 150

\section{St. Martin}

Lachnopus valgus: Girón et al. 2018: 76 - Pic Paradis, no leg.; Old Fort Hill, no leg.

This species was not in Peck $(2011,2016)$. It is reported for Anguilla by Ballou (1916: 75) and for St. Barthélemy by Gyllenhal (1834: 41). Both records were recently confirmed by Girón et al. (2018: 76) who also listed St. Martin. Elsewhere present on Puerto Rico, St. John and St. Croix (Girón et al. 2018).

\section{Lachnopus villosipes (Boheman, 1834): 43}

\section{St. Eustatius}

Lachnopus villosipes (Boheman, 1834): 43 - no locality, JEF

Not listed by Peck $(2011,2016)$ although the description of this species is based on specimens from St. Eustatius and St. Barthélemy. The types are in the NHRS (NHRS 2001).

\section{Lachnopus Schönherr, 1840: 380}

\section{St. Eustatius}

Lachnopus species: This study - The Quill, AJW; White Wall, AJW

Girón et al. (2018) recently published an annotated checklist of this genus. They could not resolve the so-called 'curvipes conflict', i.e. the fact that the variation in characters of Lachnopus curvipes (Fabricius, 1787b: 113), including the male genitalia, can overlap with those of L. valgus. According to Girón et al. (2018) L. villosipes may also be included in this conflict and a full revision would likely split the genus and synonymise several of the known taxa. As such, two St. Eustatius specimens are listed provisionally here as Lachnopus species.

\section{Litostylus pudens (Boheman, 1833): 623}

\section{Saba}

Litostylus pudens: Gillett et al. 2014: 2230 - without further data

Litostylus strangulatus (Chevrolat, 1880b): 213

\section{St. Eustatius}

Litostylus cf. strangulatus: This study - The Quill, EOC

New provisional record for Eustatius. Beaten from vegetation in a semi-evergreen forest on a relatively wet and steep slope.

Naupactus cervinus Boheman, 1840: 17 Bonaire
Pantomorus cf. fulleri: Werner 1925: 556 - no locality, AG

A widespread, polyphagous, both amphigonic and parthenogenetic reproducing weevil (Germann 2016, Rodriguero et al. 2016) provisionally recorded from Bonaire by K.M. Heller (Werner 1925).

Subfamily LIXINAE Schönherr, 1823: column 1146

Microlarinus lypriformis (Wollaston, 1861): 102

\section{Curaçao}

Microlarinus lypriformis: Bennett 1989: 390 - near the airport, FDB

Subfamily MOLYTINAE Schönherr, 1823: column 1142

Acorep Voisin, 1992: 264

\section{St. Eustatius}

Acorep species This study - The Quill, AJW; without further data

A single specimen of Acorep was delivered at the Caribbean Netherlands Science Institute on 7-x2015. The exact location and leg. are unknown. Two other specimens of the same species were collected from moss at the crater rim of the Quill. New genus record for St. Eustatius.

Anchonus magister Faust, 1893: 416

\section{St. Eustatius}

Anchonus cf. magister: This study - The Quill, KB

A single specimen of Anchonus sensu Voisin (1992) was collected at light. In the absence of a modern revision and with only the original description available this specimen is provisionally assigned to this species.

\section{Decuanellus Osella, 1977: 399}

\section{St. Eustatius}

Decuanellus species: This study - The Quill, EOC, MK \& AJW

New genus record for St. Eustatius. A single specimen sieved from leaf litter.

Pseudoalaocybites aelleni Osella, 1989: 455

Curaçao

Pseudoalaocybites aelleni Osella, 1989: 455 - Grot van

Hato, VA \& PS

Endemic to Curaçao.

\section{Subfamily SCOLYTINAE Latreille, 1804: 156}

The recent revision of the West Indian members of this group by Bright (2019) has resulted in a large series of new island records, new genera and new species. Except for Hypothenemus hampei and $H$. 
obscurus the species listed below are all new for the Dutch Antilles.

\section{Ambrosiodmus hagedorni (Iglesias, 1914): $128 \mathrm{X}$ Saba}

Ambrosiodmus hagedorni: Bright 2019: 252 - Windwardside, Scout's Place Hotel, DSS; Bud's Mountain Trail, DEB \& BAB

Ivie et al. (2008b) and Peck (2016) listed this species for Montserrat as Ambrosiodmus lecontei (Hopkins, 1915) which is synonymised by Bright (2019).

Araptus insulanus Bright, 2019: 332

\section{Curaçao}

Araptus insulanus Bright, 2019: 332 - Carmabi, RHT

Endemic to Curaçao.

Coccotrypes advena Blandford, 1894: 100

\section{Saba}

Coccotrypes advena: Bright 2019: 230 - Bottom Mtn. I Troy Trail and Crispeen Trail, DEB \& BAB

\section{Coccotrypes carpophagus (Hornung, 1842): 116 Saba}

Coccotrypes carpophagus: Bright 2019: 231 - Windwardside, RMB \& HBV; Ecolodge on Mt. Scenery, DDS \& JAS

Bright (2019) also added Antigua to the range as published by Peck (2016).

Coccotrypes cyperi (Beeson, 1929): 230

Saba

Coccotrypes cyperi: Bright 2019: 232 - Bud's Mountain Trail, DEB \& BAB

Coccotrypes dactyliperda (Fabricius, 1801a): 387 Saba

Coccotrypes dactyliperda: Bright 2019: 234 - Ecolodge on Mt. Scenery, DDS \& JAS; Mt. Scenery Trail "various collectors"

Coccotrypes distinctus (Motschulsky, 1866): 403 Curaçao

Coccotrypes distinctus: Bright 2019: 234 - Piscadera, 0,5 km N Carmabi, MCT

Also present in the northern Leeward Islands on Antigua, Montserrat and Nevis (Bright 2019).

Cryptocarenus heveae (Hagedorn, 1912): 338 Curaçao

Cryptocarenus heveae: Bright 2019: 108 - Playa Santa Cruz Rd., RHT; Playa Kanoa Rd., RHT; Weg naar Playa Kanoa, RHT; Weg naar Playa Kanoa, MCT; Christoffel N.P., North Car Route, MCT; Christoffel Pk., The Woods, RHT; Malpais Trail, RHT; Savonet, RHT
Dryocoetoides capucinus (Eichhoff, 1869): 281 Saba

Dryocoetoides capucinus: Bright 2019: 259 - Sandy Cruz Trailhead nr. Hell's Gate, DEB \& BAB

Bright's (2019) citation of Eichhoff's paper is not entirely correct. For the right citation see Wood \& Bright (1987) or the literature section below. Listed as Dryocetoides (sic!) capucinus by Peck (2016).

Hypocryphalus mangiferae (Stebbing, 1914): 542 Saba

Hypocryphalus mangiferae: Bright 2019: 112 - Windward side, RMB \& HBV; Bottom, Mountain Trail, DEB \& BAB; Crispeen Track, near Ecolodge, DEB \& $\mathrm{BAB}$

In addition to the range as published by Peck (2016) listed for St. Kitts and Antigua by Bright (2019).

Hypothenemus africanus (Hopkins, 1915): 30

Curaçao

Hypothenemus africanus: Bright 2019: 123 - Piscadera Baai, RHT

Bright (2019) also listed Montserrat for the northern Leeward Islands.

Hypothenemus carinafrons Bright, 2019: 128

Curaçao

Hypothenemus carinafrons Bright, 2019: 128 - Weg naar Playa Kanoa, MCT

Hypothenemus crudiae (Panzer, 1791): 37

\section{Saba}

Hypothenemus crudiae: Bright 2019: 131 - Ecolodge on Crispeen Track, DEB \& BAB

The name was published on page 37, not 35 as reported in most works including Wood \& Bright (1992), Peck (2016) and Bright (2019). Bright (2019) also added the northern Leeward Islands Antigua, Montserrat and Nevis to the range as published by Peck (2016).

Hypothenemus eruditus Westwood, 1834: 34

\section{Saba}

Hypothenemus eruditus: Bright 2019: 136 - Bud's Mountain Trail, DSS \& MAI; North Coast Trail Trailhead, DSS \& MAI; Spring Bay Trail, DSS \& MAI; Mount Scenery Trail, DSS \& MAI; Upper Hell's Gate, DSS \& MAI; Bud's Mountain Trail, DEB \& BAB; Crispeen Track, DEB \& BAB; Spring Bay Trail, no leg. [probably DSS \& JAS]

For the date of publication see Wheeler (1912) and Bright (2019). Bright (2019) also added Antigua to the range as published by Peck (2016) who listed this species as Hypothenemus eruditus and $H$. plumeriae. The latter was synonymised by Bright (2019). 
Hypothenemus exceptus Bright, 2019: 139
Curaçao

Hypothenemus exceptus Bright, 2019: 139 - Piscadera Bay, RHT; Weg naar Playa Kanoa, MCT

Also present on the northern Leeward Islands Redonda and Montserrat. Bright (2019) also listed a specimen under Curaçao with the label "D. Hilburn, 2.x.1987, Paget P.”. However, that record belongs under Bermuda.

\section{Hypothenemus glabratulus (Schedl, 1957): 192}

\section{Saba}

Hypothenemus glabratulus: Bright 2019: 142 - Crispeen Track, DEB \& BAB; Bottom Mountain Trail, DEB \& $\mathrm{BAB}$

Bright (2019) also listed Montserrat.

\section{Hypothenemus granulatus Bright, 2019: 144}

\section{Curaçao}

Hypothenemus granulatus Bright, 2019: 144 - Christoffel Park, Savonet, RHT; Christoffel Park, Northern Route, RHT

Endemic to Curaçao.

\section{Hypothenemus hampei (Ferrari, 1867): 12}

\section{Aruba}

Hypothenemus hampei: Haack 2001: 273 - imported into the USA

A pest of coffee. Introduced but it is unknown if the species has established itself on the island. Not mentioned for Aruba by Bright (2019).

\section{Hypothenemus interstitialis (Hopkins, 1915): 28}

\section{Saba}

Hypothenemus interstitialis: Bright 2019: 148 - Spring Bay Trail, DSS

Peck (2016) listed this species as Hypothenemus ceibae Hopkins, 1915 which is synonymised by Bright (2019).

\section{Hypothenemus javanus (Eggers, 1908): 216 \\ Curaçao}

Hypothenemus javanus: Bright 2019: 150 - Christoffel N.P., North Car Route, MCT; Piscadera Bay, RHT

The page numer of the first description is 216 , not 215 as in most publications including Wood \& Bright (1992), Peck (2016) and Bright (2019). Bright (2019) added Anguilla and Antigua to the range as published by Peck (2016) who, as well as Ivie et al. (2008b), listed this species for Montserrat as Hypothenemus brunneus Hopkins 1915. The latter was synonymised by Bright (2019).

\footnotetext{
Hypothenemus leptosquamus Bright, 2019: 152 Curaçao
}

Hypothenemus leptosquamus Bright, 2019: 152 - Christoffel Park, Savonet, RHT; Santa Rose, RHT; 1,2 km SE Lagun, RHT; Playa Santa Cruz Rd., RHT; Christoffel Park, The Woods, RHT; Malpais Trail, RHT; Playa Parasasa, RHT; Piscadera Bay, RHT

Endemic to Curaçao.

Hypothenemus obscurus (Fabricius, 1801a): 395

\section{Curaçao}

Hypothenemus obscurus: Kalshoven 1963: 233 - without further data

Hypothenemus obscurus: Bright 2019: 156 - Santa Rosa, RHT; Piscadera Bay, RHT

\section{Saba}

Hypothenemus obscurus: Bright 2019: 156 - S. coast, Giles Quarter Trail, DSS; Bud's Mountain Trail, $\mathrm{DEB} \& \mathrm{BAB}$

A pest of several fruits including macadamia nuts, Brazil nuts, nutmeg, tamarind seeds and coffee. Introduced. Bright (2019) also added Antigua to the range as published by Peck (2016).

\section{Hypothenemus parvulosus Bright, 2019: 160}

\section{Saba}

Hypothenemus parvulosus Bright, 2019: 160 - Sandy Cruz, nr Hell's Gate, DEB \& BAB; Windwardside, Crispeen Trail Trailhead, DEB \& BAB

Also present in the northern Leeward Islands on Redonda (Bright 2019).

Hypothenemus ponticus Bright, 2019: 164

\section{Curaçao}

Hypothenemus ponticus Bright, 2019: 164 - Carmabi, RHT; Christoffel Park, Orchid Trail Rd., RHT; Christoffel Park, The Woods, RHT; Malpais, Biná Trail, near entrance, $\mathrm{MCT}$

Endemic to Curaçao.

Hypothenemus pubescens Hopkins, 1915: 19

Saba

Hypothenemus pubescens: Bright 2019: 165 - Kelby Rdg. / Spring Bay Trail, no leg.

Bright (2019) also added Anguilla to the range as published by Peck (2016).

Hypothenemus rotundicollis (Eichhoff, 1878a): 385

\section{Curaçao}

Hypothenemus rotundicollis: Bright 2019: 167 - Christoffel Park, Zorgvlied Ruins Tr., RHT

\section{Saba}

Hypothenemus rotundicollis: Bright 2019: 167 - Trail to Spring Bay Trail, JAS; Trail to Spring Bay Trail, DSS; Kelby Rdg. / Spring Bay Trail, no leg.

Bright (2019) additionally listed Montserrat for the northern Leeward Islands. For the correct citation see Johnson et al. (2020). 
Hypothenemus rubrithorax Bright, 2019: 168 Saba

Hypothenemus rubrithorax Bright, 2019: 168 - Ecolodge on Mt. Scenery, DSS \& JAS

Known from two female specimens, the holotype from Saba and a paratype from St Vincent.

Hypothenemus vernaculus Bright, 2019: 174

\section{Curaçao}

Hypothenemus vernaculus Bright, 2019: 174 - Christoffel Park, Savonet, RHT; Christoffel Park, The Woods, RHT; Malpais, Biná Trail, near entrance, MCT

Endemic to Curaçao. Known from a single female specimen.

\section{Hypothenemus villosus Bright, 2019: 176}

\section{St. Eustatius}

Hypothenemus villosus Bright, 2019: 176 - Quill Trail to bottom of crater, MAI

Elsewhere known from Puerto Rico and Grenada.

Loganius ficus Schwarz, 1894: 44

Curaçao

Loganius ficus: Bright 2019: 9 - Christoffel Park, North car Route, MCT; Christoffel Park, South car Route, MCT; Weg naar Playa Kanoa, MCT; Christoffel Park, North car Route, RHT; Christoffel Park, South car Route, RHT; Weg naar Playa Kanoa, RHT

Bright (2019) also added St. Kitts to the range as published by Peck (2016) who treated this species as a member of the genus Cnemonyx. The year of publication is 1894 , not 1896 , as quoted by most previous authors including Bright (2019), Peck (2016) and Wood \& Bright (1992), nor 1895 as in Wood (1962).

\section{Loganius vagabundus Wood, 1961: 89}

\section{Curaçao}

Loganius vagabundus: Bright 2019: 10 - Christoffel Park, North car Route, MCT; Christoffel Park, Northern Route, RHT; Piscadera 0,5 km N Carmabi, MCT; Christoffel Park, Mountain Route, RHT

Bright (2019) added St. Kitts to the range as published by Peck $(2011,2016)$ who treated this species as a member of the genus Cnemonyx.

Microborus iviei Bright, 2019: 187

\section{Saba}

Microborus iviei Bright, 2019: 187 - Ecolodge on Mt. Scenery, DSS \& MAI

Also known from Montserrat and Dominica (Bright 2019). Listed in Ivie et al. (2008b) and Peck (2016) as Microborus sp.
Minyotrypetes primus Bright, 2019: 247 Curaçao

Minyotrypetes primus Bright, 2019: 247 - Christoffel Park, RHT

Endemic to Curaçao.

Neocultus thomasi Bright, 2019: 248

Curaçao

Neocultus thomasi Bright, 2019: 248 - Christoffel Park, Copper Mine Tr., RHT; Christoffel N.P., South Car Route, MCT

Endemic to Curaçao.

Phrixosoma antillicum Bright, 2019: 16 [Saba]

Phrixosoma antillicum Bright, 2019: 16 - trail to Mt. Scenery, DSS et al.

Bright (2019) listed a paratype from Saba but did not include the island in the distribution of this species, only mentioning Saint Lucia, Saint Vincent and the Grenadines.

Pityophthorus minutissimus Bright, 2019: 379 Saba

Pityophthorus minutissimus Bright, 2019: 379 - near Booby Hill, DSS \& JAS

Also known from St. Lucia.

Pseudothysanoes cracentis Bright, 2019: 88 Curaçao

Pseudothysanoes cracentis Bright, 2019: 88 - Christoffel Park, Northern Route Cave Trail, RHT; Christoffel Park, Woods, RHT

Endemic to Curaçao.

Pycnarthrum hispidum (Ferrari, 1867): 19

Curaçao

Pycnarthrum hispidum: Bright 2019: 191 - 3,3 km W. Julianadorp, RHT

Saba

Pycnarthrum hispidum: Bright 2019: 191 - Windwardside, RMB \& HBV; Scouts Place Hotel, DSS; Junction Bud's / Mount Scenery Trails, DSS et al.

Bright (2019) also added St. Kitts and Antigua to the range as published by Peck (2016).

Scolytodes glaber (Eichhoff, 1868a): 400

Saba

Scolytodes glaber: Bright 2019: 203 - Windwardside, RMB \& HBV; Scouts Place Hotel, DSS; near Booby Hill, DSS \& JAS

Listed by Ivie et al. (2008b) and Peck (2016) as Scolytodes schwarzi (Hopkins, 1902). The latter was synonymised by Bright (2019).

Scolytodes pseudobicolor (Eggers, 1940): 132 


\section{Saba}

Scolytodes pseudobicolor: Bright 2019: 213 - Trail to Spring Bay, $2 \mathrm{~km}$, JAS

Listed as a synonym of Scolytodes notatus (Eggers, 1940) by Peck (2016) but the name was resurrected by Bright (2019). Both species were described in 1940, not 1941 as in Peck (2016).

Scolytodes sabaensis Bright, 2019: 215

Saba

Scolytodes sabaensis Bright, 2019: 215 - Sandy Cruz

Trail, near Hell's Gate, DEB \& BAB

Endemic to Saba.

\section{Theoborus theobromae Hopkins, 1915: 57 \\ Saba}

Theoborus theobromae: Bright 2019: 276 - Ecolodge on Mt. Scenery, DSS \& JAS

Bright (2019) also added Montserrat to the range as published by Peck (2016).

\section{Xyleborus affinis Eichhoff, 1868a: 401}

\section{Saba}

Xyleborus affinis: Bright 2019: 288 - Ecolodge on Mt. Scenery, DSS \& JAS

Bright (2019) also added Antigua and St. Kitts to the range as published by Peck (2016), and Blandford (1898: 216) added Nevis to the range as published by Peck (2016) and Bright (2019). Blandford's record was also quoted by Leng \& Mutchler (1914: 480), Blackwelder (1947: 779) and Maes \& Martinez (1988: 8).

\section{Xyleborus ferrugineus (Fabricius, 1801a): 388}

\section{Curaçao}

Xyleborus ferrugineus: Bright 2019: 294 - Weg naar Playa Kanoa, MCT; Weg naar Playa Kanoa, RHT; Playa Santa Cruz Rd., RHT; Piscadera Baai, RHT; Christoffel N.P., Copper Mine, MCT

\section{Saba}

Xyleborus ferrugineus: Bright 2019: 294 - Windwardside, RMB \& HBV; Mt. Scenery Trail, DSS; Ecolodge on Mt. Scenery, DSS \& JAS

Bright (2019) also added Nevis and Antigua to the range as published by Peck (2016).

\section{Xyleborus spinulosus Blandford, 1898: 201}

\section{Saba}

Xyleborus spinulosus: Bright 2019: 301 - Bottom Mtn. Trail, DEB \& BAB

Bright (2019) also added Antigua to the range as published by Peck (2016).

Xyleborus volvulus (Fabricius, 1775): 454 Curaçao
Xyleborus volvulus: Bright 2019: 302 - Christoffel Park, Copper Mine Trail, RHT; Christoffel N.P., Orchard Trail, MCT

\section{Saba}

Xyleborus volvulus: Bright 2019: 302 - Windwardside, RMB \& HBV; Scout's Place Hotel, DSS

Leng \& Mutchler (1917: 220), followed by Blackwelder (1947: 780), listed Xyleborus perforans (Wollaston, 1857: 96) for St. Kitts, as well as Barbados, St. Vincent and Jamaica. Wood (1979) noted that $X$. perforans is very similar to, and doubtfully distinct from, $X$. volvulus and hesitated whether to add $X$. perforans to the American list or to place it in the synonymy. Peck (2016) wrote that except for a probable misidentification from Barbados, $X$. perforans is unreported from the New World. Gohli et al. (2016) recently concluded that both are good species which are both present in the New World. However, due to their rather limited dataset at least the evidence on which they based the latter conclusion is not very convincing. As such, it seems best to follow Wood (1979) and Peck (2016) for now and refer American records of X. perforans to X. volvulus until more solid evidence emerges. This also means that St. Kitts should be added to the range as published by Peck (2016). Bright (2019) added Antigua but did not list St. Kitts. He stated that $X$. perforans and $X$. volvulus are almost certainly synonymous.

Xylosandrus compactus (Eichhoff, 1876): 201

Saba

Xylosandrus compactus: Bright 2019: 306 - Crispeen Track nr. Ecolodge, DEB \& BAB; Mt. Scenery Trail at Mountain road, DEB \& BAB

Eichhoff described Xyleborus compactus in the third fascicule of volume 18 of the "Annales de la Société Entomologique de Belgique" which was published in 1876.

\section{Family Incertae Sedis}

Cryptophagus forsstromii Gyllenhal, 1808a: 100

\section{St. Eustatius}

Cryptophagus Forsströmii Gyllenhal, 1808a: 100 - no locality, JEF

Cryptophagus Forstromi (sic!): Billberg 1820a: 11 - without further data

According to article 32.5.2.1 of the Code (ICZN 1999) a diacritic or other mark in a name should be deleted, except that in a name published before 1985 and based upon a German word, the umlaut sign is deleted from a vowel and the letter "e" is to be inserted after that vowel. Forsström was a Swedish national so Gyllenhal's name should 
in this case be corrected to forsstromii. The current taxonomic status of this taxon is unclear. Gyllenhal did not only describe members of the family Cryptophagidae in this genus. The name has later only been used in Billberg's catalogue (1820a). Billberg's first collection was burned in 1822 and he subsequently bought the collection of Forsström which was particularly strong with insects from the Antilles. This collection was later deposited at the Natural History Museum in London (Horn \& Kahle 1935, Bousquet 2016). However, Smith (1986) also listed material from the Billberg collection as being present in HEC while the type(s) of Cryptophagus forsstromii are also mentioned as being part of the collections of both the UUZM (Wallin 2001, Telenius \& Shah 2016) as well as the NHRS (NHRS 2001). This species is not listed by Peck $(2011,2016)$. Endemic to St. Eustatius?

\section{Dermestes eustatius Linnaeus, 1758: 357 \\ St. Eustatius}

Dermestes eustatius Linnaeus, 1758: 357 - no locality, DR

Not listed by Peck $(2011,2016)$. The type is in Charles de Geer's collection in NHRS (Dobreff 2010). De Geer (1775) transferred this taxon to his new genus Ips (Scolytinae). Háva (2015) listed it as a Scolytinae but it is unclear if he saw the type(s). Bright (2019) did not mention this taxon. Linnaeus described the species from specimens collected from fungi on St. Eustatius while De Geer (1775) writes that he found a very large number of this species in a mushroom which Rolander sent him from Surinam. It might prove to be a member of the family Ciidae of which several species have been first described in the genus Dermestes. Endemic to St. Eustatius?

Erroneous records for the Dutch Antilles

Family DYTISCIDAE Leach, 1815: 84

\section{Subfamily HYDROPORINAE Aubé, 1836: 14}

Neobidessus surinamensis (Régimbart, 1889): 390 Young (1981: 331) erroneously "corrected" Régimbart's (1889) type locality "Guyane: Surinam" by stating that the types are from "Boven (Island of Bonaire near Curacao)" thereby referring to Régimbart's label marked "Neerol vd. Poll, Boven Suriname". However, Boven Suriname is Dutch for Upper Suriname, the land area along the Upper Suriname River, which stretches inland from the southern shore of Brokopondo, Surinam. Régimbart's type locality was correct and it is unclear why Young changed it. Nilsson (2001) correctly listed the type locality as "Surinam" but later, without any explanation added "[Bonaire island nr Curacao]" to the locality in his on-line catalogue (Nilsson \& Hájek 2018). Neobidessus surinamensis is not part of the Antillean fauna.

Family SCARABAEIDAE Latreille, 1802: 144

Subfamily SCARABAEINAE Latreille, 1802: 144

\section{Coprophanaeus jasius Olivier, 1789a: 109}

Olivier (1789a) described Scarabaeus jasius based on specimens from Cayenne and Curaçao (see also Gemminger \& von Harold 1869 and Gillet 1911). Arnaud (2002a) considered the types lost and designated a neotype from Cayenne. Arnaud (2002b) nor Edmonds \& Zidek (2010) mentioned a Coprophanaeus specimen from Curaçao. According to Hielkema \& Hielkema (2019) the inclusion of Curaçao in the distribution of this species is likely based on a mislabeled or misidentified specimen.

\section{Subfamily DYNASTINAE MacLeay, 1819: 64}

\section{Tomarus ebenus (De Geer, 1774): 317}

A record for St. Martin is based on Bates (1888: 318) who mentioned a specimen from St. Martin in his collection (now in BMNH). Tomarus ebenus is listed for the island by Leng \& Mutchler (1914), Blackwelder (1944a), Paulian (1947), Cartwright \& Chalumeau (1978) and Peck $(2011,2016)$ but not by Chalumeau \& Gruner (1977), Endrödi (1969, 1985), Ratcliffe (2003), Ratcliffe \& Cave $(2006,2015)$ nor López-García et al. (2016). Unfortunately, none of these authors comment on Bates' record while his work is listed in the literature sections of all these publications. In the Antilles T. ebenus is known from the southern islands Guadeloupe, Dominica, Martinique and St. Lucia while T. cuniculus is present throughout the Antilles (Ratcliffe \& Cave 2015). Bates' record is probably identified erroneously or based on a mislabeled specimen.

Family COCCINELLIDAE Latreille, 1807: 70

Subfamily COCCINELLINAE Latreille, 1807: 70

Mulsantina labyrinthica (Sicard, 1929): $517 /$ Procula ferruginea (Olivier, 1808b): 991

Both species were listed by Duverger (2001) for St. Martin but Nicolas (2012) questioned these records. Both are Greater Antillean species.

Family TENEBRIONIDAE Latreille, 1802: 165 
Subfamily OPATRINAE Brullé, 1832: 213

\section{Blapstinus fortis LeConte, 1878: 420}

Ivie \& Hart (2016: 463) suspected a single specimen from St. Martin in the Hungarian Natural History Museum (N of Cupecoy Bay, PWH) to be mislabeled. According to them the range of Blapstinus fortis is restricted to Central America, Grand Bahama, Andros, New Providence, Cuba, Isla de Juventud and Grand Cayman.

\section{Diastolinus clathratus (Fabricius, 1792b): 109}

Listed for St. Martin by several authors but this species is endemic to St. Croix (Hart \& Ivie 2016).

\section{Diastolinus clavatus Mulsant \& Rey, 1859: 91}

Listed for St. Martin, St. Barthélemy and Nevis by several authors but this species is a Puerto Rican Bank endemic (Hart \& Ivie 2016).

Diastolinus mulsanti Marcuzzi \& d'Aguilar, 1971: 79

This taxon was synonymised with Diastolinus clavatus by Hart \& Ivie (2016). However, previous records of $D$. mulsanti from St. Martin (Marcuzzi 2001: 251, Soldati \& Touroult 2014: 99) belong to $D$. perforatus (Hart \& Ivie 2016).

Diastolinus puncticollis Mulsant \& Rey, 1859: 83 This taxon was synonymised with Xerolinus sallei by Ivie \& Hart (2016). However, all previous records of Diastolinus puncticollis listed for Saba and St. Eustatius belong to D. leewardensis.

\section{Diastolinus realinoi Marcuzzi, 2002: 398}

Marcuzzi wrote that the single specimen on which his description was based (Curaçao, BMR) had possibly been transported by ship from Cuba to Curaçao. Ivie \& Hart (2016) could not investigate the type for their revision of Diastolinus. Their request to RMNH did not seem to have reached the right person. However, even if it had the result would have been the same. In 1995 Marcuzzi loaned 298 specimens of unidentified Tenebrionidae from the Zoological Museum Amsterdam (now part of RMNH) which were never returned. The type of Diastolinus realinoi was among these. The current whereabouts of the specimens are unclear (Huijbregts pers. comm. 2017). Marcuzzi's collection is now in Museo Civico di Storia Naturale "Giacomo Doria", Genova (Ivie in litt. 2020) and the type might be available there.

Xerolinus sallei (Mulsant \& Rey, 1859): 80

All previous records from Saba and St. Eustatius (as Diastolinus sallei) belong to D. leewardensis (Hart \& Ivie 2016).
Subfamily TENEBRIONINAE Latreille, 1802: 165

“Helops martinensis” Marcuzzi, 2001: 252 (nomen nudum)

Description based on a single specimen in the collection Soldati and the only known specimen of this genus from the Antilles. Marcuzzi, notorious for his carelessness (see also Ivie \& Hart 2016 and above under Diastolinus realinoi), erroneously listed two different collection dates and initials for the leg. in his description: Oyster Pond, 10-vii1994, C. Donneuve and 10-i-1994, P. Donneuve. Soldati \& Touroult 2014: 103 seem to correct this, presumably based on the label, to 10-i-1994 and P. Donneuve. Marcuzzi (2001) failed to indicate where the syntypes were deposited, a mandatory requirement for every new species name published after 1999 (ICZN 1999: Article 16.4.2). As such, the name is a nomen nudum (see also Bousquet et al. 2018). It is striking that Marcuzzi (2001) specifically mentioned the fact that "this is the first discovery of a Helops in the Antilles, since the presence of a Helops at Puerto Rico (Wolcott 1936) is doubtful"..."it was never collected again and never identified" (see also Wolcott 1951). The same now seems to apply to his description.

\section{Family CURCULIONIDAE Latreille, 1802: 195}

Subfamily SCOLYTINAE Latreille, 1804: 156

Xylosandrus compactus (Eichhoff, 1876): 201

This invasive species is listed for Curaçao in several publications, which all refer to the on-line CABI Invasive Species Compendium (CABI 2020). However, this database refers to Vázquez \& Monteagudo (1988) as its source but that paper describes the first discovery of Xylosandrus compactus on Cuba (see also Bright \& Skidmore 2002). We assume that there has been an entry error using a drop-down list in the database: Curaçao instead of Cuba.

\section{Annotations to Peck's checklists for the other northern Leeward Islands}

While working on the catalogue, Peck's $(2011,2016)$ data for the non-Dutch northern Leeward Islands Anguilla, Antigua, Barbuda, Montserrat, Nevis, St. Barthélemy and St. Kitts were also critically reviewed. Additions or corrections to the listings for these islands of species that are also present on the Dutch Antilles were dealt with above. Additions or corrections to the records of species which are not part of the Dutch Antillean fauna are listed in this paragraph. 
Family CARABIDAE Latreille, 1802: 80

Subfamily HARPALINAE Bonelli, 1810: Tabula synoptica

Selenophorus parvus Darlington, 1934: 105 Shpeley et al. (2017: 154) added Barbuda to the range as published by Peck (2016).

Family DYTISCIDAE Leach, 1815: 84

Subfamily COPELATINAE Branden, 1885: 82

Copelatus posticatus (Fabricius, 1801b): 268 Bass (2006: 33) listed this species (as Copelatus postcatus sic!) for St. Kitts and Nevis. Although Peck $(2011$, 2016) referred to Bass' paper neither of the two islands was in his list.

Subfamily COLYMBETINAE Erichson, 1837: 149

Meridiorhantus calidus (Fabricius, 1792b): 193 Peck $(2011,2016)$ listed St. Kitts and Nevis but without the asterisk indicating a new island record in his paper. We have not been able to find an earlier publication mentioning these islands. It might have been mixed up with the species mentioned above. The generic classification here follows Balke et al. (2017).

Subfamily DYTISCINAE Leach, 1815: 84

Megadytes lherminieri (Guérin, 1829): pl. 8

This species is listed in Peck $(2011,2016)$ as Megadytes giganteus (Laporte, 1835): 99 which is a junior synonym. Megadytes lherminieri is usually attributed to Laporte (1835: 99) but the description was first published by Guérin on plate 8 in his "Iconographie du règne animal de G. Cuvier". For the date of publication and use of the name "Guérin" instead of "Guérin-Méneville" see Cowan (1971), Low et al. (2013) and Bousquet (2016).

Family HYDROPHILIDAE Latreille, 1802: 136

Subfamily HYDROPHILINAE Latreille, 1802: 136

Hydrophilus ensifer Brullé 1837: 52

A record for Antigua on GBIF based on a specimen in FMNH identified by Spangler (Grant \& Turcatel 2020) is an addition to the range as published by Peck (2016). Also listed for St. Croix by Miskimen \& Bond (1970, as Hydrophilus intermedius), an island not mentioned by Peck (2016).

Tropisternus apicipalpis (Chevrolat, 1835) (no pagination, [species no. 54])
Spangler (1960: 229) listed Antigua, an island not mentioned by Peck $(2011,2016)$. For the year of publication of this species see Bousquet (2016).

Tropisternus chalybeus Laporte, 1840: 53

Antigua and Nevis are not in Peck (2016) but are listed by d'Orchymont (1921: 364) and Spangler (1960: 235), respectively.

Family HISTERIDAE Gyllenhal, 1808d: 74

Subfamily ABRAEINAE MacLeay, 1819: 25

Acritus analis LeConte, 1853b: 290

A record in GBIF from St. Kitts in FMNH identified by Rupert L. Wenzel (Grant \& Turcatel 2020) is an addition to the range as published by Peck (2016). Known elsewhere in the Antilles from Cuba and Puerto Rico (Peck 2005: 52). Peck (2016) mentioned several unnamed specimens in this genus from Antigua, Barbados, Grenada, Nevis and St. Vincent.

Acritus ignobilis (Lewis, 1888): 238

Two records in GBIF from St. Kitts and Antigua in FMNH identified by Rupert L. Wenzel (Grant \& Turcatel 2020) are additions to the range as published by Peck (2016). A widespread species which is also present on Cuba, Puerto Rico (Peck 2005: 52) and Guadeloupe (Grant \& Turcatel 2020) in the Antilles and elsewhere in Florida, Panama, Colombia (Peck 2005), Venezuela, Bolivia and Brazil (among others Grant \& Turcatel 2020).

Subfamily DENDROPHILINAE Reitter, 1909: 288

\section{Paromalus hispaniolae Marseul 1870: 101}

Several specimens from Antigua identified by Wenzel on GBIF (Grant \& Turcatel 2020) which are probably the specimens listed by Peck (2016: 53) as undetermined Paromalus.

Subfamily HISTERINAE Gyllenhal, 1808d: 74

Atholus confinis (Erichson, 1834): 154

A record in GBIF of a specimen in FMNH from St. Kitts identified by Rupert L. Wenzel (Grant \& Turcatel 2020) is an addition to the range as published by Peck (2016).

Omalodes laevigatus (Quensel, 1806): 90

The type locality of this species is St. Barthélemy, an island that was not listed by Peck (2011, 2016). There also exists a record of Omalodes sp. aff. laevigatus from St. Kitts (Alam 1990: 171). 
Family STAPHYLINIDAE Latreille, 1802: 124

Subfamily PIESTINAE Erichson, 1839: 31

\section{Piestus penicillatus (Dalman, 1821): 375}

The record of this species for St. Barthélemy (Peck $2011,2016)$ is based on an error in Erichson (1840: 834) repeated by almost all subsequent authors. Erichson referred to the original description by Dalman (1821) for the St. Barthélemy record but Dalman described Piestus penicillatus based on material collected on Guadeloupe by Forsström. Blackwelder (1943) noted the error but later failed to correct it in his checklist (Blackwelder 1944a). Blackwelder (1943) also wrote that there had been much confusion concerning this species and that records from Mexico and Brazil were questionable. According to him the only unquestioned records were those from the Antilles. Scheerpeltz (1952) later included Mexico and Brazil in the range again and, without any clarification, added the Guyanas. Navarrete-Heredia et al. (2002) considered P. penicillatus an Antillean species, as did Caron et al. (2012) in their revision of the genus. Piestus penicillatus is probably a widespread Antilles endemic present on Cuba, Grenada, Guadeloupe, Hispaniola, Jamaica, Puerto Rico, St. Lucia, Tobago and Trinidad (Blackwelder 1943) but not in the northern Leeward Islands.

Family SCARABAEIDAE Latreille, 1802: 144

Subfamily APHODIINAE Leach, 1815: 97

\section{Ataenius beattyi Chapin, 1940a: 17}

Chalumeau (1977: 235) recorded this species from St. Barthélemy, an island not listed by Peck (2011, 2016).

Ataenius picinus Harold, 1867b: 281

An additional record to Peck (2016) for St. Kitts on GBIF from UWIC (Rutherford \& Auguste 2018a).

Subfamily DYNASTINAE MacLeay, 1819: 64

Cyclocephala melanocephala (Fabricius, 1775): 36 Endrödi (1966: 258) was the only one who listed St. Barthélemy for this species. His records are probably erroneous or based on mislabeled specimens.

Cyclocephala tridentata (Fabricius, 1801a): 170 Ratcliffe \& Cave (2015) synonymised Cyclocephala tridentatus dominicensis Cartwright \& Chalumeau, 1978: 25 and C. annamariae Dutrillaux et al. 2013: 64 with this species which makes it a
Lesser Antilles endemic. They also added Montserrat to the range as published by Peck (2016).

Dyscinetus picipes (Burmeister, 1847): 79

Barbuda is a new Lesser Antillean island record added by Ratcliffe \& Cave (2015: 133).

Subfamily CETONIINAE Leach, 1815: 99

Cetonia carthami Gory \& Percheron, 1835: 243

Listed as introduced on St. Barthélemy by Questel (2018: 18). It is not clear if vouchers are available.

Protaetia fusca (Herbst, 1790): 257

Peck (2016) listed this species for St. Barthélemy without reference to a publication. It is possibly based on Questel \& Le Quellec (2012) or Questel (2014: 22). It is not clear if vouchers are available (see also Meurgey, 2017).

Family ELATERIDAE Leach, 1815: 85

\section{Subfamily DENTICOLLINAE Stein \& Weise,} 1877: 96

Hemicrepidius hemipodus (Say, 1826): 254

This is an east North-American and not an Antillean species. It was listed as common on Antigua by Marshall (1878: xxx, as Asaphes decoloratus). His account was the reason why Leng \& Mutchler (1917: 205), followed by Blackwelder (1944b: 293), include Antigua in the range of this species. Peck $(2011,2016)$ omitted these records in his checklists but without comment. Nolan (1913) provided exact dates of publication for the "Journal of the Academy of Natural Sciences of Philadelphia" between 1817 and 1845. Say's description was published in November 1826.

\section{Subfamily ELATERINAE Leach, 1815: 85}

Glyphonyx quadraticollis Champion, 1896b: 536 Leng \& Mutchler (1914: 428) were the first to list Glyphonyx quadraticollis as part of the Antiguan fauna. Their record is probably based on Champion (1896b) in the Biologia Centrali-Americana which they mentioned as one of their sources. However, Champion clearly listed the place name "Antigua" as part of a series of locations in Guatemala and not as the Caribbean island. This error was repeated by Blackwelder 1944b: 296, Peck 2011: 26 and Peck 2016: 106 and is also made for several other species on GBIF. Glyphonyx quadraticollis is not part of the Antillean fauna.

Family CANTHARIDAE Imhoff, 1856: 69

Subfamily CANTHHARINAE Imhoff,91856:2693 $08: 17: 17$ AM 
Tylocerus crassicornis (Dalman, 1823): 57

See Ivie \& Geiser (2014) for the confusion over this species' geographic provenance which, without any proof, included St. Barthélemy according to some authors. Constantin et al. (2017) recently discovered a specimen from Martinique, the only record of certain provenance. Tylocerus crassicornis is not part of the fauna of the northern Leeward Islands.

Family ANOBIIDAE Fleming, 1821: 50

Subfamily PTININAE Latreille, 1802: 112

Oviedinus dufaui (Pic, 1906): 21 and Oviedinus strangulatus (Fall, 1905): 120

Both species were included in the genus Ptinus by Peck (2016). Bellés (2010) described the genus Oviedinus for the "Ptinus semiobscurus group" as defined by Bellés (1986), which includes these two species.

Family CLERIDAE Latreille, 1802: 110

Subfamily ENOPLIINAE Gistel, 1848a: [6]

Pelonium fuscum Opitz, 2018: 464

First mentioned as Pelonium sp. nov. by Ivie et al. (2008b) from Montserrat and listed as such by Peck (2016). Also present on Guadeloupe (Opitz 2018).

Family COCCINELLIDAE Latreille, 1807: 70

Subfamily STICHOLOTIDINAE Weise, 1901: 430

Delphastus nebulosus Chapin, 1940b: 264 Listed for Nevis by Kairo et al. (2001: 48N), an island not listed by Peck $(2011,2016)$. It is not clear if vouchers are available.

Subfamily SCYMNINAE Mulsant, 1846: 189

Cryptognatha nodiceps Marshall, 1912: 321

Introduced as early as 1937 on Antigua (Cock 1985: 17). Later, in 1970, repeatedly introduced to control the coconut scale Aspidiotus destructor Signoret, 1869 (Hemiptera) on St. Kitts and Nevis with reported establishment on both islands (Cock 1985: 20, van Lenteren \& Bueno 2020: 407). None of these islands are listed by Peck (2011, 2016). It is not clear if vouchers are available.

\section{Decadiomus austrinus (Gordon, 1976): 341}

Listed as Diomus austrinus by Peck (2016) but recently transferred to Decadiomus (Vandenberg \& Hanson 2019).
Diomus thoracicus (Fabricius, 1801a): 378

Included as native on St. Kitts in Cock (1985: 55), an island not mentioned by Peck (2016). It is not clear if vouchers are available.

Hyperaspis jucunda Mulsant, 1850: 608

Introduced in 1971 from Trinidad and Tobago to St. Kitts (van Lenteren \& Bueno 2020: 407). It is not clear if the species has established itself and if vouchers are available.

Hyperaspis trilineata Mulsant, 1850: 667

Mentioned as having been introduced in 1958 on St. Kitts. In 1966 recoveries were made and in 1967 it was widespread but not island-wide (Cock 1985: 55, van Lenteren \& Bueno 2020: 411). Its current status is unknown and it is unclear if vouchers are available.

Rhyzobius fagus (Broun, 1880): 648 / Rhyzobius pulchellus (Montrouzier, 1861): 306

Probably only one of these Australian species, presumably Rhyzobius fagus, was introduced to control coconut scale. Cock (1985) listed " $R$. satelles (as R. pulchellus)" (= R. fagus) in table 3 on page 16 as being introduced to St. Kitts (in 1970-1973), Montserrat (1970) and St. Lucia (1971) but in the text on page 19 and 20 he only listed $R$. pulchellus, as being introduced to respectively Montserrat (1971) and St. Lucia (1971). It is not clear if it has established itself and if vouchers are available. Peck $(2011,2016)$ did not list a Rhyzobius species for the Lesser Antilles.

Rhyzobius lophanthae (Blaisdell, 1892): 51

Another Australian species, which was introduced in 1973 to control coconut scale on St. Kitts (Cock 1985: 16). It is not clear if the species has established itself and if vouchers are available. Not listed by Peck $(2011,2016)$.

Scymnus coccivora Ramakrishna Aiyar, 1925: 491 Peck (2016) only listed St. Kitts. According to Sagarra \& Peterkin (1999) it was also introduced on Montserrat. It is not clear if the species has established itself and if vouchers are available. Ivie et al. (2008b) mentioned a Scymnus (Pullus) sp. from Montserrat which might be this species.

Subfamily COCCINELLINAE Latreille, 1807: 70

Coelophora inaequalis (Fabricius, 1775): 80

A record from Anguilla on iNaturalist (Roy 2020) is an addition to Peck (2016). Introduced.

Family CIIDAE Leach, 1819b: 206

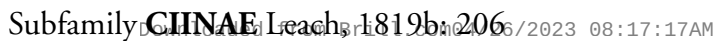
via free access 
Ceracis furcifer Mellié, 1849: 379

Pecci-Maddalena \& Lopes-Andrade (2017: 19) recently added Antigua to the range of this species as published by Peck (2016). For the date of publication see Evenhuis (2016).

Family COLYDIIDAE Billberg, 1820b: 394

Endeitoma granulata (Say, 1826): 266

Listed as Asynchita granulata (Say, 1826) by Peck (2016) but see Ivie et al. (2016). The year of publication of this species is often quoted as 1827, probably because this is the date on the cover. However, Nolan (1913) provides exact dates of publication for the "Journal of the Academy of Natural Sciences of Philadelphia" between 1817 and 1845 . Say's description was published in November 1826.

Family TENEBRIONIDAE Latreille, 1802: 165

Subfamily PIMELLINAE Latreille, 1802: 166

Ortheolus antillarum (Champion, 1896a): 5

A record for St. Barthélemy by Questel (2018: 18) is an addition to the range as published by Peck (2016). It is not clear if vouchers are available. The reference to page number 4 of Champion (1896a) in Peck (2016) is probably a typo.

Subfamily OPATRINAE Brullé, 1832: 213

Blapstinus dominicus Marcuzzi, 1962: 34 Added to the northern Lesser Antillean fauna by Ivie \& Hart (2016: 463) based on its occurrence on Anguilla.

\section{Diastolinus coarctatus (Mulsant \& Rey, 1859):} 106

Listings of this species (as Sellio coarctatus) for St. Kitts belong to Diastolinus leewardensis (Hart \& Ivie 2016).

Diastolinus costipennis Mulsant \& Rey, 1859: 85 This taxon was synonymised with Xerolinus sallei by Ivie \& Hart (2016). However, all previous records from St. Kitts belong to Diastolinus leewardensis (Hart \& Ivie 2016).

Diastolinus puncticollis Mulsant \& Rey, 1859: 83 This taxon was synonymised with Xerolinus sallei by Ivie \& Hart (2016). Except for the records for Anguilla, all previous records listed for the northern Lesser Antilles belong to Diastolinus leewardensis. The Anguillan records are D. perforatus (Hart \& Ivie 2016).
Except for the records for Anguilla, all previous records listed for the northern Lesser Antilles (as Diastolinus sallei) belong to D. leewardensis. The Anguillan records are $D$. perforatus (Hart \& Ivie 2016).

Subfamily COELOMETOPINAE Lacordaire, 1859: 358

Cyrtosoma lherminieri (Guérin-Méneville, 1844): 123

Ivie et al. (2008b) attributed the Montserrat records listed in Leng \& Mutchler (1917) to an undescribed species but that was later corrected in Spiessberger \& Ivie (2018) who referred two female 19th-century specimens collected by H.G. Hubbard on the island to this species. Both specimens are now in USNM.

Family OEDEMERIDAE Latreille, 1810: 216

Subfamily OEDEMERINAE Latreille, 1810: 216

Oxycopis vittata (Fabricius, 1775): 125

Listed for St. Barthélemy by Questel (2018: 17). It is not clear if vouchers are available.

Family CERAMBYCIDAE Latreille, 1802: 211

Subfamily CERAMBYCINAE Latreille, 1802: 211

Chlorida festiva (Linnaeus, 1758): 389

Touroult (2012, Annexe I), followed by Peck (2016), was the first to list St. Kitts for this species. However, the entry is not in bold as are the other new island records in his table and he does not mention Antigua where this species is present. Julien Touroult kindly checked his collection and there is no voucher for Saba there (Touroult 2020 in litt). Although it is certainly possible that Chlorida festiva is present on St. Kitts, this particular record is probably a typographic error.

Elaphidion antiguensis Vlasak, 2019: 442

Recently described based on specimens from Antigua.

Stizocera vanzwaluwenburgi Fisher, 1932: 46 A record from Anguilla on iNaturalist (Bourque 2019) is an addition to the range of this species as published by Peck (2016).

Family BRUCHIDAE Latreille, 1802: 192

Subfamily BRUCHINAE Latreille, 1802: 192 
Fennah (1947: 110) listed Antigua, an island not listed in Peck $(2011,2016)$. It is not clear if vouchers are available.

Stator monachus (Sharp, 1885): 471

Romero \& Johnson (2004: 628) mentioned "St. Kitts and Nevis", both islands that are not listed by Peck $(2011,2016)$. It is not clear if this species occurs on both islands or on only one of these. Romero \& Johnson's records are based on "labels of specimens in many of the larger collections of bruchids".

Family CHRYSOMELIDAE Latreille, 1802: 220

Subfamily GALERUCINAE Latreille, 1802: 228

Acalymma innubum (Fabricius, 1775): 117

Two specimens from Antigua on GBIF from UWIC (Rutherford \& Auguste 2018b) are additions to the range as published by Peck (2016).

Disonycha leptolineata Blatchley, 1917: 143 Questel (2014: 19) listed Disonycha glabrata (Fabricius, 1781): 156 for St. Barthélemy but later seemed to correct this to D. leptolineata (Questel 2018: 17). It is not clear if vouchers are available. Hitherto the only Disonycha species known in the region is D. spilotrachela (see above).

\section{Subfamily CRYPTOCEPHALINAE Gyllenhal, 1813: 582}

\section{Cryptocephalus irroratus Suffrian, 1852: 32}

Questel (2018: 17) listed this species as introduced to St. Barthélemy. This species is not mentioned by Peck (2011, 2016). It is not clear if vouchers are available.

Family BRENTIDAE Billberg, 1820a: 40

Subfamily BRENTINAE Billberg, 1820a: 40

\section{Brentus anchorago (Linnaeus, 1758): 383}

Listed by Questel (2018: 16) for St. Barthélemy. This species is not mentioned by Peck (2011, 2016). It is not clear if vouchers are available.

Family CURCULIONIDAE Latreille, 1802: 195

\section{Subfamily DRYOPHTHORINAE Schönherr, 1825: column 588}

Cosmopolites sordidus (Germar, 1823): 299 Ballou (1918: 379) reported its first occurrence on Antigua, an island not listed by Peck (2011, 2016). It is not clear if Ballou's record was based on vouchers. For the year of publication see Bousquet (2016).

Rhinostomus scrutator (Olivier, 1807): 233

A specimen found "on dried herbs" in a parcelpost package from Montserrat intercepted on December 6, 1938, in Boston is listed by Vaurie (1970). She added that it was an unusual record and that the species was probably not established on the island.

Subfamily CURCULIONINAE Latreille, 1802: 195

Anthonomus argentatus Gyllenhal, 1835c: 343

Not in Peck $(2011,2016)$ although described based on specimens from St. Barthélemy and listed by several authors including Leng \& Mutchler (1914: 472), Blackwelder (1947: 838), O’Brien \& Wibmer (1982: 106) and Clark (1990: 568).

Huaca pacha Clark, 1993: 11

Peck $(2011,2016)$ listed both Nevis and St. Kitts. We have not been able to find an earlier published record for Nevis. Clark described Huaca pacha based on two female specimens from St. Kitts (Philips Level, L.D. Coote; Bakers Ghut, L.D. Coote). A single-island endemic.

Subfamily CRYPTORHYNCHINAE Schönherr, 1825: column 585

Coelosternus balteatus Sahlberg, 1823: 50

Not in Peck $(2011,2016)$ although described based on specimens from St. Barthélemy and listed by several authors including Leng \& Mutchler (1914: 475), Blackwelder (1947: 865) and O’Brien \& Wibmer (1982: 152).

Euscepes postfasciatus (Fairmaire, 1849): 513 Myers (1931: 145, as Euscepes batatae) listed Montserrat, an island not mentioned by Peck (2011, 2016). It is not clear if vouchers are available.

Neoulosomus erinaceus (Schönherr, 1826): 294 Not in Peck $(2011,2016)$ although described based on specimens from St. Barthélemy and listed by several authors including Leng \& Mutchler (1914: 474), Blackwelder (1947: 862) and O'Brien \& Wibmer (1982: 143).

Subfamily ENTIMINAE Schönherr, 1823: column 1138

Myllocerus undecimpustulatus Faust, 1891: 266

An invasive weevil native to Sri Lanka. It was first found in the New World in 2000 in Florida (O’Brien et al. 2006), in 2016 followed by the Caymandslands (Malumphy. etrad/2018) 3 3 Questel 7 AM 
(2018) listed it for St. Barthélemy. It is not clear if vouchers are available.

Subfamily LIXINAE Schönherr, 1823: column 1146

Microlarinus lareynii (Jacquelin du Val, 1852): 714

Bennett (1971: 371) mentioned the introduction of this species on St. Kitts in 1968 as a biological control agent against the annual herb puncture vine (Tribulus cistoides). However, it did not seem to have succeeded in establishing itself on the island. Weevils were recovered in April, but none were recovered in October 1969 and in limited samplings in March 1971 (Bennett 1971, van Lenteren \& Bueno 2020: 415).

Microlarinus lypriformis (Wollaston, 1861): 102 Listed by Peck $(2011,2016)$ for the Antilles from the Bahamas, Curaçao, Jamaica, Puerto Rico and St. Kitts. Cock (1985: 116) and van Lenteren \& Bueno (2020: 415) also mentioned the introduction of this species on Nevis in 1968 as a biological control agent against the annual herb puncture vine (Tribulus cistoides). It established itself but the puncture vine stand on Nevis airport was later destroyed when the runway was enlarged. This may have eradicated the weevil population on the island (Bennett 1989). The current status of both weed and weevil on Nevis are unknown (Winston et al. 2014).

Subfamily SCOLYTINAE Latreille, 1804: 156

Ambrosiodmus devexulus (Wood, 1978): 398 Bright (2019: 252) noted that there is no voucher for the record for Montserrat in Ivie et al. (2008b) which was also listed by Peck (2016).

Ambrosiodmus obliquus (LeConte, 1878): 432 Bright (2019: 255) added Montserrat to the range as published by Peck (2016).

Araptus hymenaea (Eggers, 1933): 9

Bright (2019: 329) added Montserrat to the range as published by Peck (2016) who listed it as mentioned as an unidentified Araptus by Ivie et al. (2008b).

\section{Araptus ineditus Bright, 2019: 331}

This species is present on the Dominican Republic, Puerto Rico, Montserrat and Dominica. Ivie et al. (2008b) and Peck (2016) listed it as an unidentified Araptus.
Chramesus opacicollis Eggers, 1940: 124

Bright (2019: 40) added Montserrat to the range as published by Peck (2016) who mentioned it as listed as an unidentified Chramesus in Ivie et al. (2008b).

Chramesus squamosus Bright, 2019: 44

Endemic to Montserrat. Listed as an unidentified Chramesus in Ivie et al. (2008b) and Peck (2016).

Cladoctonus interruptus (Eggers, 1940): 126

Bright (2019: 47) added Antigua and Montserrat to the range as published by Peck (2016). Listed for Montserrat by Ivie et al. (2008b) and Peck (2016) as Cladoctonus sp.

Cnesinus brevisetosus Bright, 2019: 24

Endemic to Montserrat. Listed as Cnesinus sp. by Ivie et al. (2008b).

Cnesinus guadeloupensis Eggers, 1940: 137 Bright (2019: 24) added Montserrat to the range as published by Peck (2016). Listed as Cnesinus sp. by Ivie et al. (2008b).

\section{Coccotrypes robustus Eichhoff, 1878a: 391}

A record from Antigua for a species elsewhere known from the Greater Antilles and the Bahamas (Bright 2019: 239). A species not listed by Peck (2016).

Corthylus tuberculatus Eggers, 1940: 140 Bright (2019: 406) added Montserrat to the range as published by Peck (2016).

Cryptocarenus seriatus Eggers, 1933: 10

Bright (2019: 110) added Antigua to the range as published by Peck (2016).

Dendrocranulus fulgens Bright, 2019: 245

This species occurs on Montserrat and Martinique (Bright 2019).

Dryocoetoides cristatus (Fabricius, 1801a): 389

Bright (2019: 260) added Montserrat to the range as published by Peck (2016) who listed this species as Dryocetoides (sic!) cristatus.

Gymnochilus insularis (Eggers, 1932): 232

Listed as Gymnochilus reitteri (Eichhoff, 1878a: 388) in Ivie et al. (2008b) and Peck (2016) (Bright 2019: 184). Note that the citation for Egger's paper in Bright (2019) referred to volume 48 of the "Wiener Entomologische Zeitung". This should be volume 49. For the correct citation for $G$. reitteri see Johnson et al. (2020). 
Hylocurus anomala Bright, 2019: 74

Endemic to Montserrat. Mentioned as unidentified Hylocurus spp. in Ivie et al. (2008b) and Peck (2016).

Hypothenemus californicus Hopkins, 1915: 19

Bright (2019: 127) added Antigua to the range as published by Peck (2016).

Hypothenemus collinus Bright, 2019: 129

This species occurs on Montserrat and St. Lucia (Bright 2019).

\section{Hypothenemus erectus LeConte, 1876: 356}

Bright (2019: 29) added Montserrat to the range as published by Peck (2016). Specimens of this species from Montserrat were listed as Hypothenemus birmanus (Eichhoff, 1878a: 384) in Ivie et al. (2008b). However, Bright (2019) concluded that the characters hitherto used to distinguish the two species are all extremely variable and cannot be used to distinguish them. As such, he considered all New World identifications of the Old World tropical $H$. birmanus misidentifications. However, Bright added that further research might show that the two taxa are synonymous. For the correct citation see Johnson et al. (2020).

Hypothenemus fuscicollis (Eichhoff, 1878a): 386 Listed for Montserrat by Ivie et al. (2008b) and Peck (2016) as Hypothenemus comosus Bright, 1972: 50 which was synonymised by Bright (2019: 140). According to Bright (2019) no vouchers exist for this island record. For the correct citation see Johnson et al. (2020).

Hypothenemus gossypii (Hopkins, 1915): 25

Listed by Ivie et al. (2008b) and Peck (2016) for Montserrat but most likely based on a misidentification. Until authentic species are available this island record should be ignored (Bright 2019).

Hypothenemus obscurifrons Bright, 2019: 155

This species is present on Antigua, the Dominican Republic and Puerto Rico (Bright 2019).

Hypothenemus opacus (Eichhoff, 1872): 132 Ivie et al. (2008b) listed a specimen of Hypothenemus dolosus Wood, 1974 from Montserrat. Bright (2019: 159) synonymised this taxon with $H$. opacus. He referred to Ivie's record for Montserrat but noted that this is a literature record and there is no voucher available. Elsewhere, known from Cuba, Dominican Republic, Jamaica and Puerto Rico.
Hypothenemus pygmaeomorphus Bright, 2019: 166

Endemic to Montserrat (Bright 2019).

Hypothenemus setiferous Bright, 2019: 169

Endemic to Montserrat (Bright 2019).

Monarthrum antillicum Bright, 2019: 416

This species occurs on Montserrat, Guadeloupe and Dominica (Bright 2019).

Pagiocerus frontalis (Fabricius, 1801a): 389

Bright (2019: 29) added St. Kitts to the range as published by Peck (2016).

Pityophthorus laevis (Schedl, 1938): 181

A specimen from Montserrat (Bright 2019: 375).

A species not listed by Peck (2016).

Pityophthorus pauculus Bright, 2019: 380

New species from Montserrat and St. Lucia (Bright 2019).

Pityophthorus subconcentralis Schedl, 1938: 183 A specimen from Montserrat (Bright 2019: 387). An addition to the range as published by Peck (2016).

Premnobius cavipennis Eichhoff, 1878b: 404 Bright (2019: 249) added St. Kitts to the range as published by Peck (2016).

Pseudothysanoes lautus Bright, 2019: 92

New species from Antigua, Montserrat and Guadeloupe. Listed as Pseudothysanoes sp. for Montserrat by Ivie et al. (2008b) and Peck (2016).

Pseudothysanoes minutissimus Bright, 2019: 96 Endemic to Montserrat. Listed as an unidentified Pseudothysanoes in Ivie et al. (2008b) and Peck (2016).

Pycnarthrum pallidum (Chapuis, 1869): 41

Bright (2019: 193) added Antigua to the range as published by Peck (2016).

Scolytodes iviei Bright, 2019: 204

New species from Antigua, Montserrat, St. Kitts and Guadeloupe. Listed as Scolytodes sp. for Montserrat by Ivie et al. (2008b).

Scolytogenes jalappae (Letzner, 1849): 99

The year of publication should be 1849 , not 1848 as mentioned in most publications including Wood \& Bright (1992), Wood (2007) and 
Bright (2019). Bright (2019: 180) added Antigua and Montserrat to the range as published by Peck (2016) who listed this species as Scolytogenes knabi (Hopkins, 1915: 34). The latter taxon was synonymised with $S$. jalappae by Wood (2007).

Xyleborinus gracilis (Eichhoff, 1868b): 145

Bright (2019: 281) added Montserrat to the range as published by Peck (2016).

\section{Xyleborus bispinatus Eichhoff, 1868b: 146}

A specimen from Montserrat (Bright 2019: 291) but Bright noted that this species is doubtfully distinct from Xyleborus ferrugineus (see above under the species from the Dutch islands).

\section{Acknowledgements}

We would like to thank Jeroen van der Brugge, Thijs van den Burg, Marijke Kanters, Hannah Madden, Ellen van Norren, Wesley Overman, Rens Vogel, Sil Westra and Ambrosius van Zanten for collecting beetles outside the plots during the St. Eustatius Scientific Terrestrial Expedition. The librarians of Naturalis Biodiversity Center and the Netherlands Entomological Society were of great help during the literature research. The help of Rafael Braga (Universidade Federal do Rio de Janeiro) with identifying a female Thermonectus is highly appreciated. Ron Beenen (Naturalis Biodiversity Center) contributed several records from Bonaire and Jaap Winkelman and Dré Teunissen (both EIS) donated their collections of beetles from Bonaire and Curaçao, respectively. Mike Ivie, Fortuné Chalumeau and Julien Touroult (Muséum National d'Histoire Naturelle) provided valuable information and photos. The St. Eustatius National Parks Foundation (STENAPA) provided the collecting permits for the 2015 St. Eustatius Expedition. Oscar Vorst, the first author's mentor in coleopterology, and Hans Huijbregts, curator Coleoptera at Naturalis Biodiversity Center, took ample time to read an earlier version of this lengthy manuscript and provided useful comments and advice which helped to improve this catalogue. Michiel Boeken, Gert van Ee, Elisabeth Haber, Donna Ivie, Marijke Kanters, Mardik Leopold, Tyler Tran en Jaap Winkelman contributed their excellent photos. This study was co-funded by Naturalis Biodiversity Center, the European Invertebrate Survey, and the first author.

\section{References}

Aellen, V. \& P. Strinati, 1997. Recherches sur la faune cavernicole de Curaçao et d'Aruba (Antilles). - Stalactite 14 Supplement (Akten des 10. Nationalen Kongresses für Höhlenforschung): 275-277.
Aguirre-Tapiero, M.P. \& P.J. Johnson, 2014. A preliminary checklist, classification, and four new country records for the Elateridae (Coleoptera) of Ecuador. - Insecta Mundi 350: 1-11. https://journals.flvc.org/mundi/ article/view/0350.

Alam, M.M., 1990. Status of West Indian fruit fly in St. Kitts, W.I. - In: W.I. Knausenberger (Ed.), Proceedings of the 24th Annual Meeting of the Caribbean Food Crops Society (CFCS), 18-20 August 1988, Ocho Rios, Jamaica: pp. 171-175. Caribbean Food Crops Society, Isabela, Puerto Rico. doi: 10.22004/ ag.econ. 260328.

Alvarenga, M., 1977. Notas taxonômicas sobre a família Erotylidae (Coleoptera). - Dusenia 10: 103-107.

Anonymous, 1904. Cotton industry. - Agricultural News 3: 357.

Anonymous, 1905. A cotton-eating beetle. - Agricultural News 4: 266.

Anonymous, 1910. A cotton-eating beetle. - Agricultural News 9: 314.

Anonymous, 1913. Root borers and other grubs in West Indian soils. - Agricultural News 12: 186.

Anonymous, 1936. List of intercepted plant pests, 1935. Bureau of Entomology and Plant Quarantine, United States Department of Agriculture, 131 pp. https:// www.biodiversitylibrary.org/page/50292726.

Anonymous, 1955. Afscheidsbijeenkomst Dr. Ir. R. Flachs. - Passaat 12: 257-259, 282, 286.

Anonymous, 1959. Het Caraïbisch Marien-Biologisch Instituut. - Passaat 16: 2-5.

Anonymous, 1982. U.S. Directory of Marine Scientists 1982. - National Academy Press, Washington, D.C., USA, ix + 214 pp.

Anonymous, 1997. Jan Hendrik Stock, 22 February 1931 17 February 1997. - Contributions to Zoology 67: 3-8. http://www.repository.naturalis.nl/document/571947.

Ardoin, P., 1977. Contribution a l'étude des espèces américaines du genre Doliema Pascoe (Col. Tenebrionidae). Annales de la Société Entomologique de France (N.S.) 13: $1-20$.

Arnaud, P., 2002a. Description de nouvelles espèces de Phanaeides (Col. Scarabaeidae). - Besoiro 7: 2-9.

Arnaud, P., 2002b. Les coléoptères du monde, Vol. 28: Phanaeini: Dendropaemon, Tetramereia, Homalotarsus, Megatharsis, Diabroctis, Coprophanaeus, Oxysternon, Phanaeus, Sulcophanaeus. - Hillside Books, Canterbury, UK, 151 pp.

Arnett, R.H., Jr. \& M.C. Thomas, 2001. American beetles, Vol. 1. Archostemata, Myxophaga, Adephaga, Polyphaga: Staphyliniformia. - CRC Press, Boca Raton, FL, USA, xv + 443 pp.

Arnett, R.H., Jr., M.C. Thomas, P.E. Skelley \& J.H. Frank, 2002. American beetles, Vol. 2. Polyphaga Scarabaeoidea through Curculionoidea. - CRC Press, Boca Raton, FL, USA, xiv + 861 pp.

Assour, H.R. \& J.E. Behm, 2019. First occurrence of Cheilomenes sexmaculata (Coleoptera: Coccinellidae) on the Caribbean Island of Curaçao. - Neotropical Entomology 48: 863-865. doi 10.1007/s13744-019-00699-0. 
Aubé, C., 1836. Iconographie et histoire naturelle des coléoptères d'Europe, Tome cinquième. Hydrocanthares: vi-xi + pp. 13-48. - Méquignon-Marvis Père et fils, Paris, France. https://www.biodiversitylibrary.org/ page/34502841.

Aubé, C., 1837a. Iconographie et histoire naturelle des coléoptères d'Europe. Tome cinquième. Hydrocanthares: pp. 49-224. - Méquignon-Marvis Père et fils, Paris, France. https://www.biodiversitylibrary.org/page/ 34502795.

Aubé, C., 1837b. Essai sur le genre Monotoma. - Annales de la Société Entomologique de France 6: 453-469.

Aubé, C., 1838. Species général des hydrocanthares et gyriniens; pour faire suite au species général des coléoptères de la collection de M. le Comte Dejean. - Méquignon Père et Fils, Paris, France. xvi + 804 pp. https://www .biodiversitylibrary.org/page/39166091.

Audisio, P., 1982. Contributo alla conoscenza dei Nitidulidae (Coleoptera) della Sierra Leone. - Quaderni dell'Accademia Nazionale dei Lincei N 255: 105-114.

Audisio, P., 2011. The Nitidulidae and Kateretidae of Sardinia: recent data and updated checklist (Coleoptera). - Conservazione Habitat Invertebrati 5: 447-460.

Balazuc, J. \& F. Chalumeau, 1978. Contribution à la faune des Antilles françaises. Cicindélides (Coléopt., Caraboidea, Cicindelidae). - Nouvelle Revue d'Entomologie 8: 17-26.

Balke, M., J. Hájek \& L. Hendrich, 2017. Generic reclassification of species formerly included in Rhantus Dejean (Coleoptera, Dytiscidae, Colymbetinae). - Zootaxa 4258: 91-100. doi: 10.11646/zootaxa.4258.1.7.

Ball, G.E., 1992. Geographical distribution and evolution of the Selenophori (Harpalini) and Apenes LeConte (Lebiini) in the Antilles (Coleoptera: Carabidae). - In: G.R. Noonan, G.E. Ball \& N.E. Stork (Eds), The biogeography of ground beetles of mountains and islands: pp. 79-94. Intercept Ltd., Andover, UK.

Ball, G.E. \& D. Shpeley, 1992. Geographical distribution and evolution of the Selenophori (Harpalini) and Apenes LeConte (Lebiini) in the Antilles (Coleoptera: Carabidae). Appendix. - In: G.R. Noonan, G.E. Ball \& N.E. Stork (Eds), The biogeography of ground beetles of mountains and islands: pp. 94-121. Intercept Ltd. Andover, Hampshire, U.K.

Ball, G.E. \& D. Shpeley, 2009. A taxonomic review of the genus Apenes LeConte (Coleoptera: Carabidae: Lebiini) in the West Indies, with descriptions of new species and notes about classification and biogeography. - Annals of Carnegie Museum 78: 79-191. doi 10.2992/007.078.0201.

Ball, G.E., D. Shpeley \& D.C. Currie, 1991. The new world genus Stenomorphus Dejean (Coleoptera: Carabidae: Harpalini): classification, allometry, and evolutionary considerations. - Canadian Entomologist 123: 933-988. doi: 10.4039/Ent123933-5.

Ballerio, A., F.-T. Krell, A. Bezděk, A. Frolov, J.-B. Huchet, D. Keith, J.I. López-Colón, E. Matthews, F. Ocampo, A. Rey \& F.Z. Vaz-de-Mello, 2018. Case 3768 Hybosorus illigeri Reiche, 1853 (Insecta, Coleoptera): proposed conservation by giving it precedence over $\mathrm{Hy}$ bosorus pinguis Westwood, 1845, Hybosorus roei Westwood, 1845 and Hybosorus carolinus LeConte, 1847. - Bulletin of Zoological Nomenclature 75: 152-164. doi: 10.21805/bzn.v75.a032.

Ballou, H.A., 1912. Scale insects and their insect parasites. - West Indian Bulletin 12: 448-463.

Ballou, H.A., 1916. Insects in the Virgin Islands. Agricultural News 15: 74-75.

Ballou, H.A., 1918. Insect pests in the West Indies in 1917. - Agricultural News 17: 378-379.

Ballou, H.A., 1920. A weevil attacking agave. - Agricultural News 19: 10.

Ballou, H.A., 1922. Report on the prevalence of some pests and diseases of crops in the West Indies during 1920. West Indian Bulletin 19: 242-257 [not seen].

Ballou, H.A., 1934. Notes on some insect pests in the Lesser Antilles. - Tropical Agriculture 11: 210-212.

Baranowski, R.M. \& J.A. Slater, 2005. Lygaeidae of the West Indies. - Bulletin Florida Agricultural Experiment Stations 402: 1-266.

Barron, J.R., 1971. A revision of the Trogositidae of America north of México (Coleoptera: Cleroidea). - Memoirs of the Entomological Society of Canada 103 Suppl. S75: 1-143. doi: 10.org/10.4039/entm10375fv.

Bass, D., 2006. A comparison of the freshwater macroinvertebrate assemblages of St. Kitts and Nevis, West Indies. - Living World, Journal of the Trinidad and Tobago Field Naturalists' Club 2006: 26-37. https:// ttfnc.org/livingworld/index.php/lwj/article/view/238.

Bass, D., 2008. Freshwater macroinvertebrates and their habitats in Saba, West Indies. - Living World, Journal of the Trinidad and Tobago Field Naturalists' Club 2008: 33-38. https://ttfnc.org/livingworld/index.php/ lwj/article/view/191/0.

Bass, D., 2020. ResearchGate profile. - available at https:// www.researchgate.net/profile/David_Bass3/3.

Bates, H.W., 1872. On the longicorn Coleoptera of Chontales, Nicaragua. - Transactions of the Royal Entomological Society of London 20: 163-238. doi: 10.1111/ j.1365-2311.1872.tb01888.x.

Bates, H.W., 1887. Pectinicornia and Lamellicornia - In: F.D. Godman \& O. Salvin, (Eds), Biologia CentraliAmericana. Insecta. Coleoptera. Vol. II. Part 2.: pp. 25-160. R.H. Porter, London, UK. https://www.bio diversitylibrary.org/page/42603458.

Bates, H.W., 1888. Pectinicornia and Lamellicornia - In: F.D. Godman \& O. Salvin, (Eds), Biologia CentraliAmericana. Insecta. Coleoptera. Vol. II. Part 2.: pp. 161-336. R.H. Porter, London, UK. https://www .biodiversitylibrary.org/page/42603593.

Baumhover, A.H., A.J. Graham, B.A. Bitter, D.E. Hopkins, W.D. New, F.H. Dudley \& R.C. Bushland, 1955. Screw-worm control through release of sterilized flies. - Journal of Economic Entomology 48: 462-466. doi: $10.1093 /$ jee/48.4.462.

Beal, R.S., Jr., 1960. Descriptions, biology, and notes on the identification of some Trogoderma larvae (Coleoptera, Dermestidae). - Technical Bulletin 1228, Agricultural 
Research Service, United States Department of Agriculture, $26 \mathrm{pp}$. https://digitalcommons.usu.edu/cgi/ viewcontent.cgi? article=1002\&context=bee_lab_ba.

Bechyně, J., 1950. Notes sur Eumolpides de l'Amérique du Sud (Col. Phytophaga). - Annals and Magazine of Natural History Ser. 123: 70-85. doi: 10.1080/ 00222935008654043.

Bechyné, J., 1955. Reise des Herrn G. Frey in Südamerika: Alticidae (Col. Phytophaga). - Entomologische Arbeiten aus dem Museum G. Frey 6: 74-266. https://www .biodiversitylibrary.org/page/45917701.

Beers, C.E., J. de Freitas \& P. Ketner, 1997. Landscape ecological vegetation map of the island of Curaçao, Netherlands Antilles. - Uitgaven Natuurwetenschappelijke Studiekring voor het Caraibisch Gebied 138: 1-54.

Beeson, C.F.C., 1929. Platypodidae and Scolytidae. Insects of Samoa and other Samoan terrestrial Arthropoda. Part IV. Coleoptera Fasc. 4: pp. 217-248. British Museum (Natural History), London, UK. https:// www.biodiversitylibrary.org/page/43277922.

Bellés, X., 1985. Descripción y posición sistemática de Arachnomimus cristithorax n. gen. n. sp. (Coleoptera, Ptinidae) de Venezuela. - Miscellània Zoològica 9: 229-232. https://www.raco.cat/index.php/ Mzoologica/article/view/92010.

Bellés, X., 1986. Descripción del Ptinus angustithorax n. sp. de Venezuela y definición del "grupo semiobscurus" de la región neotropical (Coleoptera, Ptinidae). - Eos - Revista Española de Entomología 62: 23-29. https:// digital.csic.es/handle/10261/170747.

Bellés, X., 1992. Sistemática, historia natural y biogeografía del genero Pitnus Gorham, 1880 (Coleoptera, Ptinidae). - Eos - Revista Española de Entomología 6: 167192. https://digital.csic.es/handle/10261/174380.

Bellés, X., 2010. Systematics of the genus Oviedinus nov. (Coleoptera: Ptinidae), including a fossil new species from Dominican amber, biogeographical remarks and an account on fossil Ptinids. - Elytron 24: 77-88.

Bennett, F.D., 1971. Some recent successes in the field of biological control in the West Indies. - Revista Peruana de Entomologia 14: 369-373.

Bennett, F.D., 1985. Two weevil introductions. - Curculio 18: 10 .

Bennett, F.D., 1989. Microlarinus lypriformis (Coleoptera: Curculionidae) in Curacao, Venezuela, and Puerto Rico: new distribution records. - Coleopterists Bulletin 43: 390-391. https://www.jstor.org/stable/4008764.

Bennett, F.D., 2020. ResearchGate profile. - available at https://www.researchgate.net/profile/Fred_Bennett2.

Bennett, F.D. \& F.J. Simmonds, 1964. Distribution and host records of Coccinellidae in the Caribbean area. - Technical Bulletin Commonwealth Institute of Biological Control 4: 81-94.

Benschop, A., 2010. Records with photo on the citizen science website Observation.org. - https://observation .org/waarneming/view/64506415 and https://observa tion.org/waarneming/view/\%2064496187.

Benson, D.A., I. Karsch-Mizrachi, D.J. Lipman, J. Ostell \& D.L. Wheeler, 2005. GenBank. - Nucleic
Acids Research 33 (Suppl. 1): D34-D38. https://doi .org/10.1093/nar/gki063.

Bezark, L.G., A. Santos-Silva \& F. E. de L. Nascimento, 2018. A synopsis of the genus Dorcasta Pascoe, 1858 (Coleoptera, Cerambycidae, Lamiinae, Apomecynini). - Zootaxa 4399: 49-68. doi: 10.11646/ zootaxa.4399.1.3.

Billberg, G.J., 1820a. Enumeratio insectorum in Museo Gust. Joh. Billberg. - Gadel, Stockholm, Sweden, 138 pp.

Billberg, G.J., 1820b. Novae insectorum species descriptae. - Mémoires de l' Académie Impériale des Sciences de St-Pétersbourg 7: 381-395.

Bitter, B.A., 1949. Geschiedenis van de bijenteelt op de Nederlandse Antillen. - West-Indische Gids 30: 170174. doi: 10.1163/22134360-90000237.

Blackwelder, R.E., 1943. Monograph of the West Indian beetles of the family Staphylinidae. - United States National Museum Bulletin 182: 1-658. doi: 10.5479/ si.03629236.182.i.

Blackwelder, R.E., 1944a. Checklist of the coleopterous insects of Mexico, Central America, the West Indies, and South America, pt. 1. - Bulletin of the United States National Museum 185 (1): 1-188. doi: 10.5479/ si.03629236.185.i.

Blackwelder, R.E., 1944b. Checklist of the coleopterous insects of Mexico, Central America, the West Indies, and South America, pt. 2. - United States National Museum Bulletin 185 (2): 189-341. doi: 10.5479/ si.03629236.185.2.

Blackwelder, R.E., 1945. Checklist of the coleopterous insects of Mexico, Central America, the West Indies, and South America, pt. 3. - United States National Museum Bulletin 185 (3): 343-550. doi: 10.5479/ si.03629236.185.3.

Blackwelder, R.E., 1946. Checklist of the coleopterous insects of Mexico, Central America, the West Indies, and South America, pt. 4. - United States National Museum Bulletin 185 (4): 551-763. doi: 10.5479/ si.03629236.185.4.

Blackwelder, R.E., 1947. Checklist of the coleopterous insects of Mexico, Central America, the West Indies, and South America, pt. 5. - United States National Museum Bulletin 185 (5): 765-925. doi: 10.5479/ si.03629236.185.765.

Blackwelder, R.E., 1957. Checklist of the coleopterous insects of Mexico, Central America, the West Indies, and South America, pt. 6. - United States National Museum Bulletin 185 (6): 927-1492. doi: 10.5479/ si.03629236.185.927.

Blaisdell, F.E., 1892. A new species of Coleoptera from California. - Entomological News 3: 51.

Blake, D.H., 1928. Notes on some West Indian Chrysomelidae. - Bulletin of the Brooklyn Entomological Society 23: 93-98.

Blake, D.H., 1959. Seven new galerucid beetles from the West Indies. - Journal of the Washington Academy of Sciences 49: 178-182. https://www.jstor.org/ stable/24534724. 
Blake, D.H., 1965. Fourteen new chrysomelid beetles from the West Indies (Coleoptera). - Proceedings of the Entomological Society of Washington 67: 101111. https://www.biodiversitylibrary.org/page/26388 671.

Blanchard, C.É., 1845. Histoire naturelle des insectes leurs moeurs, leurs métamorphoses et leur classification ou traité élémentaire d'entomologie. Tome second. - F. Savy, Paris, France, 524 pp., pls. 11-20. doi: 10.5962/ bhl.title.35820.

Blandford, W.F.H., 1894. The rhynchophorous Coleoptera of Japan. Part III. Scolytidae. - Transactions of the Entomological Society of London 1894: 53-141.

Blandford, W.F.H., 1898. Scolytidae. - In: F.D. Godman \& O. Salvin (Eds), Biologia Centrali-Americana Insecta Coleoptera, Vol. IV. Part 6 (cxl): pp. 185-224. R.H. Porter, London, UK.

Blatchley, W.S., 1917. On some new or noteworthy Coleoptera from the west coast of Florida. - Canadian Entomologist 49: 137-143. doi: 10.4039/Ent49137-4.

Blatchley, W.S., 1920. Notes on the winter Coleoptera of western and southern Florida, with descriptions of new species. II. - Canadian Entomologist 52: 68-72. https://doi.org/10.4039/Ent5268-3.

Boeken, M., 2014. Saba en zijn orchideeën. - Orchideeën 76 (5), Saba Special: 100-117. https://www.dcbd .nl/sites/www.dcbd.nl/files/documents/ORC_0514 _LowRes proef 4.pdf.

Boeken, M., 2018. New avifaunal records and checklist for the island of Saba, Caribbean Netherlands. - Journal of Caribbean Ornithology 31: 57-64. http://jco.birdsca ribbean.org/index.php/jco/article/view/729.

Boheman, C.H., 1833. Cyphus pudens. - In: C.J. Schönherr, Genera et species curculionidum, cum synonymia hujus familiae; species novae aut hactenus minus cognitae, descriptionibus A Dom. Leonardo Gyllenhal, C.H. Boheman, et entomologis aliis illustratae. Tomus primus. Pars prima: pp. 623-624. Roret, Paris, France.

Boheman, C.H., 1834. Ptilopus villosipes. - In: C.J. Schönherr, Genera et species curculionidum, cum synonymia hujus familiae; species novae aut hactenus minus cognitae, descriptionibus A Dom. Leonardo Gyllenhal, C.H. Boheman, et entomologis aliis illustratae. Tomus secundus. Pars prima: pp. 43-44. Roret, Paris, France.

Boheman, C.H., 1840. Naupactus cervinus. - In: C.J. Schönherr, Genera et species curculionidum, cum synonymia hujus familiae; species novae aut hactenus minus cognitae, descriptionibus A Dom. Leonardo Gyllenhal, C.H. Boheman, O.J. Fahraeus et entomologis aliis illustratae. Tomus sextus. Pars prima. Supplementum continens: p. 17. Roret, Paris, France.

Boheman, C.H., 1854. Monographia cassididarum. Tomus secundus. - Officina Norstedtiana, Stockholm, Sweden. 506 pp. + pls 5-6. https://www.biodiversitylibrary.org/item/37920.

Boheman, C.H., 1856. Catalogue of coleopterous insects in the collection of the British Museum. Part IX. Cassididae. - The Trustees, London, UK, 225 pp. https:// www.biodiversitylibrary.org/item/122395.
Bonadona, P., 1981. Contribution à l'étude des Anthicidae des Antilles françaises (Coleoptera). - Annales de la Société Entomologique de France (N.S.) 17: 273-286.

Bonelli, F.A., 1810. Observations entomologiques. Première partie (Cicindélètes et portion des Carabiques). - Félix Galletti, Turin, 58 pp. + table.

Bonfils, J. \& A.J. Bart, 1967. Distribution of sweet potato weevils in the French West Indies. - In: E.A. Tai, W.B. Charles, E.F. Iton, P.H. Haynes \& K.A. Leslie (Eds), Proceedings of the International Symposium on Tropical Root Crops, St. Augustine, Trinidad, 2-8 April, 1967, Vol. 2: pp. 27-29. University of the West Indies, St. Augustine, Trinidad and Tobago.

Bonnissent, D., 2020. ResearchGate profile. - available at https://www.researchgate.net/profile/Bonnissent_Do minique.

Booth, R.G. \& A. Polaszek, 1996. The identities of ladybird beetle predators used for whitefly control, with notes on some whitefly parasitoids, in Europe. - Brighton Crop Protection Conference, Pests \& Diseases. Proceedings of an International Conference, Brighton, UK, 18-21 November 1996, Vol. 1: pp. 69-74. British Crop Protection Council, Farnham, UK.

Bos, O.G., P.A.J. Bakker, R.J.H.G. Henkens, J.A. de Freitas \& A.O. Debrot, 2018. Preliminary checklist of extant endemic species and subspecies of the windward Dutch Caribbean (St. Martin, St. Eustatius, Saba and the Saba Bank). - Wageningen Marine Research report C067/18. Wageningen University \& Research, Wageningen/Naturalis Biodiversity Center, Leiden, The Netherlands/CARMABI, Curaçao, 69 pp. https://ede pot.wur.nl/460388.

Bottimer, L.J., 1968. Notes on Bruchidae of America north of Mexico with a list of world genera. - Canadian Entomologist 100: 1009-1049. doi: 10.4039/ Ent1001009-10.

Bouchard, P., Y. Bousquet, A.E. Davies, M.A. AlonsoZarazaga, J.F. Lawrence, C.H.C. Lyal, A.F. Newton, C.A.M. Reid, M. Schmitt, S.A. Ślipiński \& A.B.T. Smith, 2011. Family-group names in Coleoptera (Insecta). - ZooKeys 88: 1-972. https://zookeys.pensoft .net/article/4001/.

Bourque, A., 2019. Record with photo on iNaturalist. https://www.inaturalist.org/observations/20955386, https://www.inaturalist.org/observations/20907847, https://www.inaturalist.org/observations/20907854.

Bousquet, Y., 2012. Catalogue of Geadephaga (Coleoptera, Adephaga) of America, north of Mexico. ZooKeys 245: 1-1722. doi: 10.3897/zookeys.245. 3416.

Bousquet, Y., 2016. Litteratura Coleopterologica (17581900): a guide to selected books related to the taxonomy of Coleoptera with publication dates and notes. - ZooKeys 583: 1-776. doi: 10.3897/zookeys.583 .7084 .

Bousquet, Y., 2018. The dating of the fourth volume of Guillaume-Antoine Olivier's "Entomologie, ou histoire naturelle des insects". - ZooKeys 734: 137-148. https://zookeys.pensoft.net/article/22901/. 
Bousquet, Y. \& P. Bouchard, 2013. The genera in the second catalogue (1833-1836) of Dejean's Coleoptera collection. - ZooKeys 282: 1-219. doi: 10.3897/ zookeys.282.4401.

Bousquet, Y., D.B. Thomas, P. Bouchard, A.D. Smith, R.L. Aalbu, M.A. Johnston, W.E. Steiner Jr., 2018. - Catalogue of Tenebrionidae (Coleoptera) of North America. - ZooKeys 728: 1-455. doi: 10.3897/zoo keys.728.20602.

Braga, R.B., K.B. Miller \& N. Ferreira Junior, 2013. Species identification of Thermonectus females (Coleoptera, Dytiscidae). - Poster presented at the Annual Meeting of the Southwestern Branch of the Entomological Society of America, February 25-28, 2013, Las Cruces, NM, USA.

Breuning, S., 1927. Monographie der Gattung Calosoma Web. (Carab.). - Koleopterologische Rundschau 13: 129-232. https://www.zobodat.at/pdf/ KOR_13_1927_0129-0232.pdf.

Bridwell, J.C., 1929. A preliminary generic arrangement of the palm bruchids and allies (Coleoptera) with descriptions of new species. - Proceedings of the Entomological Society of Washington 31: 141-160. https://www .biodiversitylibrary.org/page/16145133.

Bridwell, J.C., 1932. The subfamilies of the Bruchidae (Coleoptera). - Proceedings of the Entomological Society of Washington 34: 100-106. www.biodiversitylibrary.org/page/16144332.

Bright, D.E., 1972. The Scolytidae and Platypodidae of Jamaica (Coleoptera). -Bulletin of the Institute of Jamaica. Science Ser. 21: 1-108.

Bright, D.E., 2019. Studies on West Indian Scolytidae (Coleoptera) 7. A taxonomic monograph of the bark and ambrosia beetles of the West Indies (Coleoptera: Curculionoidea: Scolytidae). - Occasional Papers of the Florida State Collection of Arthropods 12: 1-491.

Bright, D.E. \& R.E. Skidmore, 2002. A catalog of Scolytidae and Platypodidae (Coleoptera). Supplement 2. (1995-1999). - NRC Research Press, Ottawa, ON, Canada, viii +523 pp.

Broun, T., 1880. Manual of the New Zealand Coleoptera. [Part I.] - Colonial Museum and Geological Survey Department, Wellington, New Zealand, xix + 651 pp.

Broun, T., 1883. Revision of the New Zealand Cossonidae, with descriptions of new species New Zealand. - New Zealand Journal of Science 1: 487-499.

Brûlé, S., E. Poirier \& F. Deknuydt, 2017. Mise à jour des connaissances sur les buprestes des Petites Antilles (Coleoptera: Buprestidae). - Contribution à l'étude des Coléoptères des Petites Antilles (supplément a Le Coléoptériste) 3: 64-66.

Brullé, A., 1832. Famille des Opatrites. - In: J.B.G.M. Bory de Saint-Vincent. Expédition scientifique de Morée. Section des sciences physiques. Tome III. 1.re partie. Zoologie. Deuxième section. Des animaux articulés: p. 213. F.G. Levrault, Paris, France.

Brullé, A., 1837. Tribu des Palpicornes. Famille des Hydrophiliens. - In: A. d'Orbigny (Ed.), Voyage dans l'Amérique méridionale (le Brésil, la République orientale de l'Uruguay, la République Argentine, la Patagonie, la République du Chili, la République de Bolivie, la République du Pérou), exécuté pendant les années 1826, 1827, 1828, 1829, 1830, 1831, 1832 et 1833 par Alcide d'Orbigny. Tome sixième. 2e Partie: Insectes: pp. 52-59. P. Bertrand, Paris \& V. Levrault, Strasbourg. https://www.biodiversitylibrary.org/page/ 2531016.

Brzoska, D.W., 2020. David Brzoska. - Digital publication available at https:/www.facebook.com/david .brzoska.3.

Buck, F.D., 1960. Anthicid beetles from Venezuela, Colombia, Cuba and the Netherlands Antilles. - Studies on the Fauna of Curaçao and other Caribbean Islands 10: 64-71. http://www.repository.naturalis.nl/ document/549935.

Burckhardt, R. \& S.A. Slipinski, 1991. A review of the Passandridae of the world (Coleoptera, Cucujoidea). III. Genera Anisocerus, Aulonosoma, Passandrella, Passandrina, Scalidiopsis and Taphroscelidia. - Revue Suisse de Zoologie 98: 453-498. www.biodiversitylibrary.org/ page/41270734.

Burgers, A.C.J., 1953. The fruitfly Anastrepha serpentina in Curaçao. - Studies on the Fauna of Curaçao and other Caribbean Islands 4: 149-153. http://www.repository .naturalis.nl/document/549911.

Burmeister, H., 1842. Handbuch der Entomologie. Dritter Band. Besondere Entomologie, Fortsetzung. Coleoptera Lamellicornia Melitophila. - Theod. Chr. Friedr. Enslin, Berlin, Germany, xxii + 828 pp.

Burmeister, H., 1847. Handbuch der Entomologie. Fünfter Band. Besondere Entomologie, Fortsetzung. Coleoptera Lamellicornia Xylophila et Pectinicornia. - Theod. Chr. Friedr. Enslin, Berlin, Germany, viii + 584 pp.

CABI, 2020. CAB International Invasive Species Compendium. - Digital publication available at http://www .cabi.org/isc.

Cambefort, Y., 2006. Des coléoptères, des collections et des hommes. - Publications scientifiques du Muséum, Paris, France, 375 pp.

Campbell, J.M., 1971. A revision of the Alleculidae (Coleoptera) of the West Indies. - Memoirs of the Entomological Society of Canada 103 (supplement 81): 7-140. doi: $10.4039 /$ entm $10381 \mathrm{fv}$.

Candèze, E., 1857. Monographie des Élatérides. Tome premier. - H. Dessain, Liége, Belgium, viii + 400 pp. + 7 pls. https://www.biodiversitylibrary.org/item/36961.

Candèze, E., 1859. Monographie des Élatérides. Tome second. - H. Dessain, Liége, Belgium, 543 pp. + 6 pls. https://www.biodiversitylibrary.org/item/36951.

Candèze, E., 1860. Monographie des Élatérides. Tome troisième. - H. Dessain, Liége, Belgium, 512 pp. +5 pls.

Caron, E., C.S. Ribeiro-Costa \& A.F. Newton, 2012. Cladistic analysis and revision of Piestus Gravenhorst with remarks on related genera (Coleoptera: Staphylinidae: Piestinae). - Invertebrate Systematics 25: 490-585. doi: 10.1071/IS10016. 
Cartwright, O.L. \& F.E. Chalumeau, 1978. Bredin-Archbold-Smithsonian Biological Survey of Dominica. The superfamily Scarabaeoidea (Coleoptera). - Smithsonian Contributions to Zoology 279: 1-32. doi: 10.5479/ si.00810282.279.

Casey, T.L., 1890. Coleopterological notices I. - Annals of the New York Academy of Sciences 5: 39-198. doi: 10.1111/j.1749-6632.1890.tb57003.x.

Casey, T.L., 1891. Coleopterological notices III. - Annals of the New York Academy of Sciences 6: 9-214. doi: 10.1111/j.1749-6632.1892.tb55403.x.

Casey, T.L., 1895. Coleopterological notices VI. - Annals of the New York Academy of Sciences 8: 435-838. doi: 10.1111/j.1749-6632.1894.tb55429.x.

Casey, T.L., 1899. A revision of the American Coccinellidae. - Journal of the New York Entomological Society 7: 71-169. https://www.biodiversitylibrary.org/ page/9198721.

Casey, T.L. 1916. Some random studies among the Clavicornia. - Memoirs on the Coleoptera 7: 35-300. https://www.biodiversitylibrary.org/page/960527.

Casey, T.L., 1924. Additions to the known Coleoptera of North America. - Memoirs on the Coleoptera 11: 1-347. https://www.biodiversitylibrary.org/ page/33150513.

Cazier, M.A. \& L. Lacey, 1952. The Cerambycidae of the Bahama Islands, British West Indies (Coleoptera). American Museum Novitates 1588: 1-55. http://hdl .handle.net/2246/2397.

CBS, 2010. Statistical yearbook of the Netherlands Antilles 2010. - Central Bureau of Statistics, Willemstad, Curaçao, Netherlands Antilles, ix + 108 pp. http:// digitallibrary.cbs.cw/content/CB/S0/00/00/05/00054/ Statistical\%20Yearbook\%202010.pdf.

CBS, 2011. Statistical yearbook 2010. - Central Bureau of Statistics, Oranjestad, Aruba, xi + 104 pp. https://cbs.aw/wp/index.php/2013/03/06/statistical -yearbook-2010/?download $=6867$.

Chalumeau, F., 1977. Contribution à l'étude des Scarabaeoidea des Antilles (Corrigenda et Addenda aux Scarabaeoidea des Antilles françaises). - Bulletin Mensuel de la Société Linnéenne de Lyon 46: 231-240. http://www .linneenne-lyon.org/depot/1392.pdf.

Chalumeau, F., 1982. Tenebrionidae des Antilles françaises: description d'une nouvelle espèce, désignation de lectotypes et observations diverses [Col.]. - Bulletin de la Société Entomologique de France 87: 187-195. https:// www.persee.fr/doc/bsef_0037-928x_1982_num _87_5_18023.

Chalumeau, F., 1983a. Les coléoptères scarabaeides des Petites Antilles (Guadeloupe à Martinique): taxonomie, éthologie, biogéographie. - Lechevalier, Paris, France, 295 pp.

Chalumeau, F., 1983b. Un nouvel Psammodius (Scarabaeidae: Aphodiinae: Psammodiini) des Antilles et notes concernant divers Psammodiini de l'hémisphère Ouest. - Bulletin de la Société Entomologique Suisse 56: 83-87. http://www.e-periodica.ch/cntmng?pid= seg-001:1983:56::443.
Chalumeau, F., 1983c. Acanthocinini des Petites Antilles. Nouveaux taxa et observations diverses (Coleoptera: Cerambycidae: Lamiinae). - Nouvelle Revue d'Entomologie 13: 219-237.

Chalumeau, F., 1985. Phyllophaga Harris 1826 (Melolonthinae): désignation de types et peuplement des Iles Sous-le-Vent (Antilles) (Coleoptera, Scarabaeidae). Nouvelle Revue d'Entomologie (N.S.) 2: 21-34.

Chalumeau, F., 2020. ResearchGate profile. - available at https://www.researchgate.net/profile/Fortune_Chal umeau.

Chalumeau, F. \& B. Brochier, 2007. The Chiasognathinae of the Andes. Taxonomy, ethology, biogeography. Taita Publishers, Hradec Králové, Czech Republic, 324 pp.

Chalumeau, F. \& L. Gruner, 1974. Scarabaeoidea des Antilles françaises, 1re partie. - Annales de la Société Entomologique de France (N.S.) 10: 781-819.

Chalumeau, F. \& L. Gruner, 1976. Scarabaeoidea des Antilles françaises, 2 me partie: Melolonthinae et Rutelinae. - Annales de la Société Entomologique de France (N.S.) 12 (1): 83-112.

Chalumeau, F. \& L. Gruner, 1977. Scarabaeoidea des Antilles françaises, 3 me partie: Dynastinae et Cetoniinae. - Annales de la Société Entomologique de France (N.S.) 13 (4): 579-612.

Chalumeau, F. \& J. Touroult, 2004. Nouveaux Elaphidiini des Petites Antilles et notes diverses (Coleoptera, Cerambycidae). - Lambillionea 104: 751-755. https:// www.researchgate.net/publication/312155257_Nou veaux_Elaphidiini_des_Petites_Antilles_et_notes_di verses_Coleoptera_Cerambycidae_Cerambycinae.

Chalumeau, F. \& J. Touroult, 2005. Les Longicornes des Petites Antilles (Coleoptera, Cerambycidae), taxonomie, éthologie, biogéographie. - Pensoft Publishers, Sofia, Bulgaria, $241 \mathrm{pp}$.

Champion, G.C., 1885. Fam. Tenebrionidae. - In: F.D. Godman \& O. Salvin (Eds), Biologia Centrali-Americana Insecta Coleoptera, Vol. IV. Part 1. Heteromera (part) (part xli): pp. 121-136. R.H. Porter, London, UK. https://www.biodiversitylibrary.org/page/580449.

Champion, G.C., 1896a. On the heteromerous Coleoptera of St. Vincent, Grenada, and the Grenadines. - Transactions of the Royal Entomological Society of London 44: 1-54. doi: 10.1111/j.1365-2311.1896 .tb00955.x.

Champion, G.C., 1896b. Fam. Elateridae. - In: F.D. Godman \& O. Salvin (Eds), Biologia Centrali-Americana Insecta Coleoptera Vol. III. Part 1. Serricornia (cxxx): pp. 529-552. R.H. Porter, London, UK. https://www .biodiversitylibrary.org/page/579687.

Champion, G.C., 1905. Pseudomopsis, gen. nov. - In: F.D. Godman \& O. Salvin (Eds), Biologia Centrali-Americana Insecta Coleoptera Vol. IV. Part 4. Rhynchophora: pp. 486-490. R.H. Porter, London, UK. https://www .biodiversitylibrary.org/page/582365.

Champion, G.C., 1913. Notes on various Central American Coleoptera, with descriptions of new genera and species. - Transactions of the Royal Entomological 
Society of London 61: 58-169. doi: 10.1111/j.13652311.1913.tb02781.x.

Champion, G.C., 1918. Notes on various species of the American genus Astylus, Cast., with descriptions of their sexual characters [Coleoptera]. - Annals and Magazine of Natural History Ser. 9, 2: 337-367. doi: $10.1080 / 00222931808562378$.

Chapin, E.A., 1935. New species of Scarabaeidae (Coleoptera) from Puerto Rico and the Virgin Islands. Journal of Agriculture of the University of Puerto Rico 19: 67-72. https://revistas.upr.edu/index.php/jaupr/ article/view/14285.

Chapin, E.A., 1940a. A revision of the West Indian beetles of the scarabaeid subfamily Aphodiinae. - Proceedings of the United States National Museum 89: 1-49. doi: 10.5479/si.00963801.89-3092.1.

Chapin, E.A., 1940b. New genera and species of ladybeetles related to Serangium Blackburn (Coleoptera: Coccinellidae). - Journal of the Washington Academy of Sciences 30: 263-272. https://www.jstor.org/ stable/24530288.

Chapuis, F., 1869. Synopsis des Scolytidae (Prodrome d'un travail monographique). - J. Desoer, Liége, Belgium,, 61 pp. https://books.google.nl/books?hl=en\&lr=\&id=AtDAAAAYAAJ\&oi=fnd \&pg=PA1 \&dq=Chapuis, $+\mathrm{F}$., $+1869 .+$ Synopsis + des + Scolytidae + (Prodrome $+\mathrm{d} \% 27 \mathrm{u}$ $\mathrm{n}+$ travail + monographique $).+$ Kots $=\mathrm{uUBxGOFT}$ ca\&si $\mathrm{g}=1 \mathrm{Q} 3$ OP59GVInNkLdN26dlVcc0eMY\#v=onepage \&q\&f=false.

Chassain, J. \& J. Touroult, 2012. Les élatérides des Antilles françaises (Coleoptera, Elateridae). - Contribution à l'étude des Coléoptères des Petites Antilles (supplément a Le Coléoptériste) 1: 58-69.

Chemsak, J.A., 1966. Descriptions and records of West Indian Cerambycidae (Coleoptera). - Proceedings of the United States National Museum 118): 209-220. doi: 10.5479/si.00963801.118-3526.209.

Chevrolat, A., 1835. Coléoptères du Mexique I. 3e Fascicule: [48] pp. - G. Silbermann, Strasbourg, Germany. https://www.biodiversitylibrary.org/page/32777214.

Chevrolat, A., 1862. Coléoptères de l'île de Cuba. Notes, synonymies et descriptions d'espèces nouvelles. Familles des Cérambycides et des Parandrides. - Annales de la Société Entomologique de France (Sér. 4) 2: 245-280. https://www.biodiversitylibrary.org/page/8239187.

Chevrolat, A., 1880a. Diagnoses de Chelonarium de la collection de M. Chevrolat. - Le Naturaliste 2: 260-261.

Chevrolat, A., 1880b. Diagnoses de Curculionides de la Guadeloupe. - Le Naturaliste 2: 213-214.

Clairville, J.P., 1806. Helvetische Entomologie oder Verzeichniss der schweizerischen Insekten nach einer neuen Methode geordnet. Zweiter Theil. - Orell, Füssli und Compagnie, Zürich, xliii +247 pp. +32 pls. https://www.biodiversitylibrary.org/page/15702948.

Clark, W.E., 1978. The weevil genus Sibinia Germar: natural history, taxonomy, phylogeny, and zoogeography, with revision of the New World species (Coleoptera: Curculionidae). - Quaestiones Entomologicae 14: 91-387. https://www.biodiversitylibrary.org/ page/51239241.
Clark, W.E., 1990. Revision of the Anthonomus subgenus Anthonomocyllus Dietz (Coleoptera: Curculionidae). Quaestiones Entomologicae 26: 559-600.

Clark, W.E., 1993. Huaca Clark, new genus of Neotropical Anthonomini (Coleoptera: Curculionidae). - Transactions of the American Entomological Society 119: 1-45. https://www.jstor.org/stable/25058245.

Clark, S.M., T. Lillrose \& L.A. Belo Neto 2013. Leaf beetles of the Cayman Islands (Coleoptera: Chrysomelidae). - Insecta Mundi 279: 1-41. https://journals.flvc .org/mundi/article/view/81556/0.

Cobben, R.H., 1960. The Heteroptera of the Netherlands Antilles I. Foreword Gerridae, Veliidae, Mesoveliidae (Water Striders). - Studies on the Fauna of Curaçao and other Caribbean Islands 11: 1-34. http://www.re pository.naturalis.nl/document/549877.

Cock, M.J.W., 1985. A review of biological control of pests in the Commonwealth Caribbean and Bermuda up to 1982. - CABI Publishing, Wallingford, UK, 218 pp.

Connell, W.A., 1963. Carpophilus pilosellus Motschulsky, new synonymy and distribution (Coleoptera: Nitidulidae). - Coleopterists Bulletin 17: 89-90. https://www .jstor.org/stable/3999385.

Constantin, R., F. Deknuydt \& E. Dumbardon-Martial, 2017. Découverte de Tylocerus crassicornis (Dalman, 1823) en Martinique (Coleoptera Cantharidae). - l'Entomologiste 73: 61-62. https://www .researchgate.net/profile/Robert_Constantin $2 /$ publi cation/322209663_Decouverte_de_Tylocerus_crassi cornis_Dalman_1823_en_Martinique_Coleoptera _Cantharidae/links/5a5221560f7e9bbc105493eb/De couverte-de-Tylocerus-crassicornis-Dalman-1823-en -Martinique-Coleoptera-Cantharidae.pdf.

Coomans, H.E., 1974. Life and malacological work of Hendrik Elingsz van Rijgersma (1835-1877): a Dutch physician and scientist on St. Martin, Netherlands Antilles. - Bijdragen tot de Dierkunde 44 (2): 115-214. doi: 10.1163/26660644-04402001.

Coquerel, C., 1850 [1849]. Observations entomologique sur divers Coléoptères recueillis aux Antilles (1 re partie). - Annales de la Société Entomologique de France (Sér. 2) 7: 441-454.

Cortés-Hernández, K.A. \& R.S. Anderson, 2019. Two new species of Isodrusus Sharp, 1911 (Coleoptera: Curculionidae: Entiminae: Tanymecini). - Coleopterists Bulletin 73: 940-944. doi: 10.1649/0010 -065X-73.4.940.

Cowan, C.F., 1971. On Guérin's Iconographie: particularly the insects. - The Journal of the Society for the Bibliography of Natural History 6: 18-29 doi: 10.3366/ jsbnh.1971.6.1.18.

Crowson, R.A., 1964. A review of the classification of Cleroidea (Coleoptera), with descriptions of two new genera of Peltidae and several new larval types. - Transactions of the Royal Entomological Society of London 116 (12): 275-327. doi: 10.1111/j.1365-2311.1964 .tb02298.x.

Csiki, E., 1909. Újabb adatok Magyarország bogárfaunájához (8. pótjegyzék a faunakatalogushoz). Rovartani Lapok 16: 3-6. 
Cupello, M., 2018. On the types species of the New World dung beetle genus Canthidium Erichson, 1847 (Coleoptera: Scarabaeidae: Scarabaeinae), with an annotated checklist of species. - Zootaxa 4388: 451-486. doi: 10.11646/zootaxa.4388.4.1.

d'Orchymont, A., 1921. Le genre Tropisternus I (Coleoptera: Hydrophilidae). - Annales de la Société Entomologique de Belgique 61: 349-374.

Dalens, P.-H., 2020. ResearchGate profile. - available at https://www.researchgate.net/profile/Pierre_Henri _Dalens.

Dalman, J.W. 1821. Nya genera och species af Insecter. - Kungliga Svenska Vetenskapsakademiens Handlingar 1821: 372-387. https://www.biodiversitylibrary.org/ page/34532440.

Dalman, J.W., 1823. Analecta entomologica. - J.P. Lindh, Stockholm, Sweden, vii $+104+4$ pls.

Darlington, P.J. Jr. 1934. New West Indian Carabidae, with a list of the Cuban species. - Psyche 41: 66-131. doi: 10.1155/1934/10161, doi: 10.1155/1934/57 348.

Davey, P.M., 1958. The groundnut bruchid, Caryedon gonagra (F.). - Bulletin of Entomological Research 49: 385-404. doi: 10.1017/S0007485300053694.

De Geer, C., 1774. Memoires pour servir a l'histoire des insectes. - Tome quatrième. Pierre Hesselberg, Stockholm, Sweden, xii + 456 pp. +19 pls.

De Geer, C., 1775. Memoires pour servir a l'histoire des insectes. - Tome cinquième. Pierre Hesselberg, Stockholm, Sweden, vii +448 pp. +16 pls.

Debrot, A.O., 2006. Preliminary checklist of extant and fossil endemic taxa of the ABC-Islands, Leeward Antilles. - CARMABI Foundation, Curaçao, Netherlands Antilles. https://www.dcbd.nl/sites/www.dcbd.nl/files/docu ments/Debrot $\% 25202006 \% 2520$ Endemic\%2520 species\%2520checklist\%2520Leewards.pdf.

Debrot, A.O. \& R.P.M. Bak, 2019. Brief history of Carmabi (Caribbean Research and Management of Biodiversity), Curaçao, up to 2010. - 'ad HOC': Newsletter 'Historie van de Oceanografie Club' 16: 9-18. https:// edepot.wur.nl/478445.

Deelder, C.L., 1942. Revision of the Erotylidae (Coleoptera) of the Leiden Museum. - Zoologische Mededelingen 24: 49-115. https://www.repository.naturalis.nl/ document/149346.

Dejean, P.M.F.A., 1825. Species général des coléoptères de la collection de M. le Comte Dejean. Tome premier. - Crevot, Paris, France, xxx + 463 pp. https://www.bio diversitylibrary.org/page/1988310.

Dejean, P.M.F.A., 1829. Species général des coléoptères de la collection de M. le Comte Dejean. Tome quatrième. - Méquignon-Marvis, Paris, France, vii + 520 pp. https://www.biodiversitylibrary.org/page/9377 833.

Dejean, P.M.F.A., 1831. Species général des coléoptères de la collection de M. le Comte Dejean. Tome cinquième. - Méquignon-Marvis, Paris, France, viii + 883 pp. https://www.biodiversitylibrary.org/page/9374909.

Dejean, P.M.F.A., 1833. Catalogue des coléoptères de la collection de M. le Comte Dejean. livraison 1: pp. 1-96.
- Méquignon-Marvis, Paris. https://www.biodiversitylibrary.org/page/9322489.

Deler-Hernández, A., F. Cala-Riquelme \& M. Fikácek, 2014. A review of the genus Oosternum Sharp of the West Indies (Coleoptera: Hydrophilidae: Sphaeridiinae). - Deutsche Entomologische Zeitschrift 61: 43-63. doi: 10.3897/dez.61.7566.

Delobel, A., M. Sembène, G. Fédière \& D. Roguet, 2003. Identity of the groundnut and tamarind seed-beetles (Coleoptera: Bruchidae: Pachymerinae), with the restoration of Caryedon gonagra (F.). - Annales de la Société Entomologique de France (N.S.) 39: 197-206. doi: 10.1080/00379271.2003.10697375.

Delplanque, A. \& F. Chalumeau, 1975. Insectes de la Guadeloupe. - Centre Départemental de Documentation Pédagogique, Pointe-à-Pitre, Guadeloupe, $47 \mathrm{pp}$.

Delplanque, A. \& F. Chalumeau, 1985. Insectes de la Guadeloupe et îles avoisinantes, 2e éd. revue et corrigée. - Centre Départemental de Documentation Pédagogique, Pointe-à-Pitre, Guadeloupe, 45 pp.

DeMaster, N., 2018. Record with photo on iNaturalist. https://www.inaturalist.org/observations/16186519.

Denon, D. \& H. Mauléon, 2004. Le charançon de la patate douce en Guadeloupe. Cylas formicarius menace gravement la survie de la culture. - Phytoma 573: 14-15.

Dobreff, J., 2010. Daniel Rolander: The invisible naturalist. - In: A. Polaszek (Ed.), Systema Naturae 250 - The Linnaean Ark: pp. 11-28, Appendix 1. CRC Press, Boca Raton, FL, USA.

Dobreff, J., C. Dahlman, D. Morgan \& J. Tipton, 2009. Daniel Rolander's Journal (1754-1756). - In: Hansen, L. (Ed.), The Linnaeus Apostles: Global Science \& Adventure, Vol. 3 (3): pp. 997-1581. IK Foundation \& Co., London, UK.

dos Santos, A.T. \& C.S. Ribeiro-Costa, 2019. Rearrangements in some species groups of Amblycerus Thunberg, 1815 (Coleoptera: Chrysomelidae: Bruchinae) including keys, description of a new species, new host plant and distributional records. - Zootaxa 4701: 101-148. doi: 10.11646/zootaxa.4701.2.1.

Drury, D., 1773. Illustrations of Natural History, wherein are exhibited upwards of two hundred and forty figures of exotic insects according to their different genera; very few of which have hitherto been figured by any author, being engraved and coloured from nature, with the greatest accuracy, and under the author's own inspection, on fifty copper-plates. With a particular description of each insect: interspersed with remarks and reflections on the nature and properties of many of them. Vol. II. - D. Drury, London, UK, vii +90 pp. +50 pls. https://books.google.nl/books? $\mathrm{hl}=$ en $\& \mathrm{lr}=\& \mathrm{id}=\mathrm{nG}$ OFAAAAQAAJ \&oi=fnd $\& p g=\mathrm{PR} 1$ \&ots=UC_0I9fCp8\&sig=hxBzaLHwqVnJG86opo _8o16-5zY\#v=onepage\&q\&f=false.

Dupont, H., 1838. Monographie des trachydérides de la famille des longicornes. - Magasin de Zoologie 8: i-xiii + 1-28, pls. 186-200 \& 29-59, pls 204-224.

Dutrillaux B., F. Chalumeau, A-M. Dutrillaux, T. Giannoulis \& Z. Mamuris, 2013. Séparation taxonomique en trois espèces au sein des populations de Cyclocephala Downloaded from Brill.com04/26/2023 08:17:17AM via free access 
tridentata Fabricius (Coleoptera: Scarabaeidae: Dynastinae), sur la base de critères génétiques, chromosomiques et géographiques. - Annales de la Société Entomologique de France (N.S.) 49: 61-67. doi: 10.1080/00379271.2013.767020.

Duverger, C., 2001. Coccinellidae (Caraïbes) Petites Antilles. - Digital publication available at http://www .aberlentomo.fr/07_supplem_ento/Duverger\%20Coc cinelles\%20Caraibes\%202001.doc.

Edmonds, W.D. \& J. Zidek, 2010. A taxonomic review of the neotropical genus Coprophanaeus Olsoufieff, 1924 (Coleoptera: Scarabaeidae, Scarabaeinae). - Insecta Mundi 129: 1-111. https://journals.flvc.org/mundi/ article/view/0129.

Eggers, H., 1908. Fünf neue Borkenkäfer. - Entomologische Blätter 4: 214-217. https://www.zobodat.at/ pdf/Entomologische-Blaetter_4_0214-0217.pdf.

Eggers, H., 1932. Borkenkäfer (Ipidae, Col.) aus Südamerika. V. Die Gattung Problechilus Eichh. Mit 8 neuen Arten. - Wiener Entomologische Zeitung 49 (4): 226 235. https://www.zobodat.at/pdf/WEZ_49_0226 -0235.pdf.

Eggers, H., 1933. Borkenkäfer (Ipidae, Col.) aus Südamerika VI. Material des Muséum Paris aus Franz. Guayana und Venezuela. - Travaux du Laboratoire d'Entomologie, Muséum National d'Histoire Naturelle, Mémoires originaux 1: 1-37.

Eggers, H., 1940. Borkenkäfer aus Südamerika (Coleoptera: Ipidae). IX. Insel Guadeloupe. - Arbeiten über Morphologische und Taxonomische Entomologie aus Berlin-Dahlem 7: 123-141.

Ehn, M. \& T.A. Zanoni, 2002. The herbarium and botanical art of Hendrik Elingsz van Rijgersma. - Taxon 51: 513-520. doi: 10.2307/1554865.

Eichelbaum, F., 1915. Verbesserungen und Zusätze zu meinem Katalog der Staphylinidengattungen aus dem Jahre 1909. - Archiv für Naturgeschichte (A) 81: 98120. https://www.biodiversitylibrary.org/item/47527.

Eichhoff, W., 1868a [1867]. Neue amerikanische Borkenkäfer-Gattungen und Arten. - Berliner Entomologische Zeitschrift 11: 399-402. https://www.biodiversitylibrary.org/page/9215667.

Eichhoff, W., 1868b. Neue amerikanische BorkenkäferGattungen und Arten (Zweites Stück). - Berliner Entomologische Zeitschrift 12: 145-152. https://www .biodiversitylibrary.org/page/8344379.

Eichhoff, W., 1869 [1868]. Neue exotische Xyleborus-Arten. - Berliner Entomologische Zeitschrift 1: 280-282. https://www.biodiversitylibrary.org/page/8344514.

Eichhoff, W., 1872 [1871]. Neue exotische TomicidenArten. - Berliner Entomologische Zeitschrift 15: 131-136. https://www.biodiversitylibrary.org/page/92 09297.

Eichhoff, W., 1876. Scolytides recueillis au Japon par M.G. Lewis. - Annales de la Société Entomologique de Belgique 18: 197-204.://www.biodiversitylibrary.org/ page/ 12720550 .

Eichhoff, W., 1878a. Neue oder noch unbeschriebene Tomicinen. - Stettiner Entomologische Zeitung
39: 383-392. https://www.biodiversitylibrary.org/ page/8988581.

Eichhoff, W., 1878b. Ratio, desgriptio, emendatio eorum Tomicinorum qui sunt in Dr medic. Gliapiiisii et autoris ipsius gollegtionibus et quos praeterea recognovit. - Memoires de la Societe Royale des Sciences de Liége Ser. 2, 8: 1-531. https://www.biodiversitylibrary.org/ page/27390602.

Emery, C., 1886. Ueber Phylogenie und Systematik der Insekten. - Biologisches Centralblatt 5: 648-656. https://www.biodiversitylibrary.org/page/1777241.

Endrödi, S., 1966. Monographie der Dynastinae (Coleoptera, Lamellicornia) I. Teil Tribus Cyclocephalini. - Entomologische Abhandlungen Museum für Tierkunde Dresden 33: 1-457.

Endrödi, S., 1969. Monographie der Dynastinae 4. Tribus: Pentodontini (Coleoptera, Lamellicornia) 1. Amerikanische Pendodontini. - Entomologische Abhandlungen Museum für Tierkunde Dresden 37: 1-145.

Endrödi, S., 1976. Monographie der Dynastinae 5. Tribus: Oryctini (die arten von Amerika) (Coleoptera: Melolonthidae). - Folia Entomologica Hungarica (N.S.) 29: 9-174.

Endrödi, S., 1985. The Dynastinae of the world. - Junk Publishers, Dordrecht, The Netherlands, 800 pp. +46 pls.

EPPO, 2009. First record of Rhynchophorus ferrugineus in Curaçao, Netherlands Antilles. - EPPO Reporting Service 2009 (1): 2009/002. https://gd.eppo.int/ reporting/article-45.

Erichson, W.F., 1834. Uebersicht der Histeroides der Sammlung. - In: J.C.F. Klug (Ed.), Jahrbücher der Insectenkunde mit besonderer Rücksicht auf die Sammlung in Königl. Museum in Berlin. Erster Band: pp. 83-208. Enslin, Berlin, Germany. https://www.biodiversitylibrary.org/page/12253507.

Erichson, W.F., 1837. Die Käfer der Mark Brandenburg. Erster Band, Erste Abtheilung. - F.H. Morin, Berlin, Germany, viii + 384 pp. https://www.biodiversitylibrary.org/item/132640.

Erichson, W.F., 1839. Genera et species staphylinorum insectorum coleopterorum familiae. Accedunt tabulae aeneae quinque. Erster Band: pp. 1-400. - F.H. Morin, Berlin, Germany. https://www.biodiversitylibrary. org/item/121676.

Erichson, W.F., 1840. Genera et species staphylinorum insectorum coleopterorum familiae. Accedunt tabulae aeneae quinque. Zweiter Band: pp. 401-954. - F.H. Morin, Berlin, Germany. https://www.biodiversitylibrary.org/page/39356946.

Erichson, W.F., 1842. Beitrag zur Insecten-Fauna von Vandiemensland, mit besonderer Berücksichtigung der geographischen Verbreitung der Insecten. - Archiv für Naturgeschichte 8: 83-287. https://www.biodiversitylibrary.org/page/13672266.

Erichson, W.F., 1843. Versuch einer systematischen Eintheilung der Nitidularien. - Zeitschrift für die Entomologie 4 (2): 225-361.://www.biodiversitylibrary. org/page/24560855. 
Erichson, W.F., 1845. Naturgeschichte der Insecten Deutschlands. Erste Abtheilung. Coleoptera. Dritter Band. Erste Lieferung: pp. 1-160. - Nicolai, Berlin, Germany. https://www.biodiversitylibrary.org/page/ 8642832.

Erichson, W.F., 1847. Naturgeschichte der Insecten Deutschlands. Erste Abtheilung. Coleoptera. Dritter Band. Fünfte Lieferung: pp. 641-800. - Nicolai, Berlin, Germany. https://www.biodiversitylibrary.org/ page/8643445.

Erichson, W.F., 1849. Insecten. - In: R. Schomburgk (Ed.), Reisen in Britisch-Guiana in den Jahren 1840 1844 im Auftrag Sr Majestät des Königs von Preussen. Dritter Theil. Versuch einer Fauna und Flora von Britisch-Guiana 3: pp. 553-617. Weber, Leipzig, Germany. https://www.biodiversitylibrary.org/page/35303 487.

Escobar-Domínguez, A.A., J. Romero-Nápoles, A. Equihua-Martínez, J.L. Carrillo-Sánchez \& S. RamírezAlarcón, 2018. Brúquidos (Coleoptera: Bruchidae) asociados a semillas de especies del género Mimosa L. (Leguminosae: Mimosoideae). - Acta Zoológica Mexicana (n.s.) 34: 1-17. https://azm.ojs.inecol.mx/index .php/azm/article/view/2149/2247.

Evenhuis, N.L., 1997. Litteratura taxonomica dipterorum (1758-1930); being a selected list of the books and prints of Diptera taxonomy from the beginning of Linnean zoological nomenclature to the end of the year 1930, Vol. II: L-Z: pp. 427-871. - Backhuys Publishers, Leiden, The Netherlands.

Evenhuis, N.L., 2016. Natural History Journal Dating. Bishop Museum. Digital publication available at http://hbs.bishopmuseum.org/dating/.

Fabricius, J.C., 1775. Systema entomologiae, sistens insectorum classes, ordines, genera, species, adjectis synonymis, locis, descriptionibus, observationibus. - Kortii, Flensburg/Leipzig, Germany, 832 pp. doi: 10.5962/ bhl.title.36510.

Fabricius, J.C., 1781. Species insectorum, exhibentes eorum differentias specificas, synonyma auctorum, loca natalia, metamorphosin, adjectis observationibus, descriptionibus. Tom. I. - C.E. Bohn, Hamburg/ Cologne, Germany, viii + 552 pp. doi: 10.5962/bhl. title.36509.

Fabricius, J.C., 1787a. Mantissa insectorum sistens species nuper detectas adjectis synonymis, observationibus, descriptionibus, emendationibus. Tom. II. - C.G. Proft, Kopenhagen, Denmark, 382 pp. doi: 10.5962/bhl. title.36471.

Fabricius, J.C., 1787b. Mantissa insectorum sistens eorum species nuper detectas adjectis characteribus genericis, differentiis specificis, emendationibus, observationibus. Tom. I. - C.G. Proft, Kopenhagen, Denmark, xx + 348 pp. doi: 10.5962/bhl.title.11657.

Fabricius, J.C., 1792a. Entomologia systematica emendata et aucta. Secundum classes, ordines, genera, species adjectis synonimis, locis, observationibus, descriptionibus. Tom. I. Pars 2. - C.G. Proft, Kopenhagen, Denmark, 538 pp. doi: 10.5962/bhl.title.125869.
Fabricius, J.C., 1792b. Entomologia systematica emendata et aucta. Secundum classes, ordines, genera, species adjectis synonimis, locis, observationibus, descriptionibus. Tom. I. [Pars 1]. - C.G. Proft, Kopenhagen, Denmark, xx + 330 pp. doi: 10.5962/bhl.title.125869.

Fabricius, J.C., 1798. Supplementum entomologiae systematicae. - Proft et Storch, Kopenhagen, Denmark, 572 pp. https://www.biodiversitylibrary.org/ page/42138493.

Fabricius, J.C., 1801a. Systema eleutheratorum secundum ordines, genera, species: adjectis synonymis, locis, observationibus, descriptionibus. Tomus II. - Bibliopolii Academici Novi, Kiel, Germany, 687 pp. https://gal lica.bnf.fr/ark:/12148/bpt6k97106v.

Fabricius, J.C., 1801b. Systema eleutheratorum secundum ordines, genera, species: adjectis synonymis, locis, observationibus, descriptionibus. Tomus I. - Bibliopolii Academici Novi, Kiel, Germany, xxiv + 506 pp. https:// gallica.bnf.fr/ark:/12148/bpt6k97105h.

Fagel, G., 1959. Osoriinae (Coleoptera Polyphaga, Fam. Staphylinidae) - In: H. de Saeger (Ed.), Exploration du Parc National de la Garamba, Mission H. de Saeger (1954-1968), 205 pp. + 154 Figs. Fascicule 12, Hayez, Brussels, Belgium. http://www.biodiv.be/archives_rdc/ archives/publications/exploration-parc-national-de-la -garamba/mission-h-de-saeger-1954-1968/1959-fasci cule-12-osoriinae-coleoptera-polyphaga-fam.-staphy linidae/fasc12-gastonfagel1959_complet.pdf.

Fägerström, C., 2020. Lund Museum of Zoology - Insect collections (MZLU). Version 367.652. - Occurrence dataset. doi: 10.15468/dahk2a accessed via GBIF.org on 2020-02-02.

Fåhraeus, O.J., 1839. Bruchus flavescens. In: C.J. Schoenherr (Ed.), Genera et species curculionidum, cum synonymia hujus familiae. Species novae aut hactenus minus cognitae, descriptionibus a Dom. Leonardo Gyllenhal, C.H. Boheman, et entomologis aliis. Tomus quintus, pars prima: pp. 32-33. - Roret, Paris, France. https://www.biodiversitylibrary.org/page/12169 757.

Fairmaire, L., 1849. Essai sur les Coléoptères de la Polynesie (Suite). - Revue et Magasin de Zoologie Pure et Appliquée (2) 1: 504-516. https://www.biodiversitylibrary.org/page/2343864.

Fall, H.C., 1905. Revision of the Ptinidae of boreal America. - Transactions of the American Entomological Society 31: 97-296. https://www.jstor.org/ stable/25076791.

Faust, J., 1891. Curculioniden aus Ost-Indien. - Entomologische Zeitung 52: 259-287. https://www.biodiversitylibrary.org/page/9008208.

Faust, J., 1893. Einige neue Anchoniden des Königl. Naturhist. Museum in Brüssel. - Annales de la Société Entomologique de Belgique 37: 407-421.://www.biodiversitylibrary.org/page/13945895.

Faust, J., 1896. Reise von E. Simon in Venezuela. Curculionidae. Pars tertia. - Entomologische Zeitung 57: 33-136. https://www.biodiversitylibrary.org/page/900 8450 . 
Fauvel, A., 1891. Voyage de M. E. Simon au Vénézuela (Décembre 1887 - Avril 1888). 11e Mémoire (1). Staphylinides. - Revue d'Entomologie 10: 87-127. https://www.biodiversitylibrary.org/page/25453415.

Fauvel, A., 1901. Voyage de M. le Dr. Ed. Bugnion au Venezuela, en Colombie et aux Antilles. Staphylinides. - Revue d'Entomologie 20: 69-91. https://www.biodiversitylibrary.org/page/10988919.

Fennah, R.G., 1947. The insect pests of food-crops in the Lesser Antilles. - Department of Agriculture for the Windward Islands, St. George's, Granada \& Department of Agriculture for the Leeward Islands, St. John's, Antigua, British West Indies, 207 pp.

Ferrari, J.A., 1867. Die Forst- und Baumzuchtschädlichen Borkenkäfer (Tomicides Lac.) aus der Familie der Holzverderber (Scolytides Lac), mit besonderer Berücksichtigung vorzüglich der europäischen Formen, und der Sammlung des k.k. zoologischen Kabinetes in Wien. - Carl Gerold's Sohn, Vienna, Austria, 95 pp. https:// www.e-rara.ch/zut/content/zoom/7119734.

Ferrer, J., 2011. Revisíon del género Zophobas Dejean, 1834 (Coleoptera, Tenebrionidae, Tenebrionini). Boletin de la Sociedad Entomológica Aragonesa 48: 287-319. http://sea-entomologia.org/Publicaciones/ PDF/BOLN_48/287319BSEA48Zophobas.pdf.

Ferrer, J. \& G. Moraguès, 2001. Contribution à l'étude des représentants américains du genre Trichoton Hope, 1840, avec description de quatre nouvelles espèces (Coleoptera, Tenebrionidae). - Bulletin de la Société Entomologique de France 106: 497-518. https://www.persee .fr/doc/bsef_0037-928x_2001_num_106_5_16799.

Fiaboe, K.K.M., R.W. Mankin, A.L. Roda, M.T.K. Kairo \& C. Johanns, 2011. Pheromone-food-bait trap and acoustic surveys of Rhynchophorus ferrugineus (Coleoptera: Curculionidae) in Curacao. - Florida Entomologist 94: 766-773. doi: 10.1653/024.094.0406.

Fisher, W.S., 1932. New West Indian cerambycid beetles. Proceedings of the United States National Museum 80: 1-93. doi: 10.5479/si.00963801.2922.

Fisher, W.S., 1942 [1941]. New Coleoptera from Puero Rico. - Journal of Agriculture of the University of Puerto Rico 25: 37-39. https://revistas.upr.edu/index .php/jaupr/article/view/3522.

Fleming, J., 1821. Supplement to the fourth, fifth and sixth editions of the Encyclopaedia Britannica with preliminary dissertations on the history of the sciences, Vol. 5. Supplement to the Encyclopaedia Britannica. Insecta: pp. 41-56, pl. 85. - A. Constable and Company, Edinburgh, UK. https://digital.nls.uk/encyclopae dia-britannica/archive $/ 192547786 \#$ ? $\mathrm{c}=0 \& \mathrm{~m}=0 \& \mathrm{~s}=0 \&$ $\mathrm{cv}=315 \& \mathrm{xywh}=2442 \% 2 \mathrm{C} 610 \% 2 \mathrm{C} 3098 \% 2 \mathrm{C} 2782$.

Fleutiaux, E. \& A. Sallé, 1890 [1889]. Liste des Coléoptères de la Guadeloupe et description d'espèces nouvelles. - Annales de la Société Entomologique de France Ser. 6, 9: 351-484. https://www.biodiversitylibrary.org/page/32438903.

Fransen, C.H.J.M., L.B. Holthuis \& J.P.H.M. Adema, 1997. Type-catalogue of the decapod Crustacea in the collections of the Nationaal Natuurhistorisch Museum, with appendices of pre-1900 collectors and material. - Zoologische Verhandelingen Leiden 311: 1-344. http://www.repository.naturalis.nl/document/149022.

Franz, N.M., 2016. SCAN Collection of Externally Processed Specimens (Arthropod Systematics Research). https://scan-bugs.org/portal/collections/individual/in dex.php?occid=23776797\&clid=0,indspec23776797.

Franz, N.M. \& S.Z. Yusseff Vanegas, 2009. The University of Puerto Rico at Mayagüez insect collection - Then and now. - Entomological News 120: 401-408. doi: 10.3157/021.120.0409.

Freitag, R., 1992. Biogeography of West Indian tigerbeetles (Coleoptera: Cicindelidae). - In: G.R. Noonan, G.E. Ball \& N.E. Stork (Eds), The biogeography of ground-beetles of mountains and islands: pp. 123-158. Intercept Ltd., Andover, UK.

Freitas, J.A. de, B.S.J. Nijhof, A.C. Rojer \& A.O. Debrot 2005. Landscape ecological vegetation map of the island of Bonaire (southern Caribbean). - Caribbean Research and Management of Biodiversity Foundation, Willemstad, Curaçao/Royal Netherlands Academy of Arts and Sciences, Amsterdam, The Netherlands, vii + 9-64 pp.

Freitas, J.A. de, A.C. Rojer, B.S.J. Nijhof \& A.O. Debrot, 2014. Landscape ecological vegetation map of Sint Eustatius (Lesser Antilles). - Caribbean Research and Management of Biodiversity Curaçao/Royal Netherlands Academy of Arts and Sciences, The Netherlands/Institute for Marine Resources and Ecosystem Studies, Amsterdam, The Netherlands, vii + 8-66 pp. + map. https://library.wur.nl/WebQuery/wurpubs/ fulltext/217984.

Freitas, J.A. de, A.C. Rojer, B.S.J. Nijhof \& A.O. Debrot, 2016. A landscape ecological vegetation map of Saba (Lesser Antilles). - IMARES report C195/15, IMARES, Wageningen UR, The Netherlands, 48 pp. https://library.wur.nl/WebQuery/wurpubs/fulltext/ 376259.

Freude, H., 1967. Revision der Epitragini (Coleoptera,Tenebrionidae) I. Teil. - Entomologische Arbeiten aus dem Museum G. Frey 18: 137-307. https://www.zobodat.at/pdf/Entomologische-Arbeit en-Museum-Frey_18_0137-0307.pdf.

Gahan, C.J., 1895. On the longicorn Coleoptera of the West India Islands. - Transactions of the Entomological Society of London 43: 79-140. doi: 10.1111/ j.1365-2311.1895.tb01665.x.

Galileo, M.H.M. \& U.R. Martins, 1993. Revisão da tribu Solenopterini (Coleoptera, Cerambycidae, Prioninae). Parte III. Gênero Solenoptera A.-Serville, 1832. Revista Brasileira de Entomologia 37: 425-458.

Ganglbauer, L., 1899. Die Käfer von Mitteleuropa. Die Käfer der österreichisch-ungarischen Monarchie, Deutschlands, der Schweiz, sowie des französischen und italienischen Alpengebietes. Dritter Band. Familienreihe Staphylinoidea. II. Theil. Scydmaenidae, Silphidae, Clambidae, Leptinidae, Platypsyllidae, Corylophidae, Sphaeriidae, Trichopterygidae, Hydroscaphidae, Scaphidiidae, Histeridae. Familienreihe 
Clavicornia. Sphaeritidae, Ostomidae, Byturidae, Nitidulidae, Cucujidae, Erotylidae, Phalacridae, Thorictidae, Lathridiidae, Mycetophagidae, Colydiidae, Endomychidae, Coccinellidae. - Carl Gerold's Sohn, Vienna, Austria, I-III, 409-1046. https://www.biodiversitylibrary.org/page/13983234.

Gasca-Álvarez, H.J. \& C. Deloya, 2015. A new species and first record of Cotinis Burmeister (Coleoptera: Scarabaeidae: Cetoniinae) for Venezuela. - Zootaxa 3948: 125-136. doi: 10.11646/zootaxa.3948.1.8.

Gebien, H.S., 1928. Über einige Gruppen Amerikanischer Tenebrioniden (Col. Heter.) I. Teil. - Stettiner Entomologische Zeitung 89: 97-164. https://www.zobodat.at/pdf/Entomologische-Zeitung-Stettin_89_00 97-0164.pdf.

Geijskes, D.C. \& P. Wagenaar Hummelinck, 1951. Entomological research in the Netherlands Antilles. - In: Kruseman, G. jr. et al. (Eds.), Entomology in the Netherlands and their overseas territories. Presented to the members of the IXth International Congress of Entomology, Amsterdam, August 17-24, 1951: pp. 61-63. Netherlands Entomological Society, Amsterdam, The Netherlands.

Gemminger, M. \& E. von Harold, 1869. Catalogus coleopterorum hucusque descriptorum synonymicus et systematicus. Tom. IV. Scarabaeidae: pp. 979-1346. - E.H. Gummi, Munich, Germany. https://www.biodiversitylibrary.org/page/9641549.

Gemminger, M. \& E. von Harold, 1871. Catalogus coleopterorum, hucusque descriptorum synonymicus et systematicus. Tomus VIII. Curculionidae: pp. 21812668. - E.H. Gummi, Munich, Germany. https:// www.biodiversitylibrary.org/page/9649110.

Génier, F. \& A. Davis, 2017. Digitonthophagus gazella auctorum: an unfortunate case of mistaken identity for a widely introduced species (Coleoptera: Scarabaeidae: Scarabaeinae: Onthophagini). - Zootaxa 4221: 497500. doi: 10.11646/zootaxa.4221.4.8.

Génier, F. \& F.T. Krell, 2017. Case 3722. Scarabaeus gazella Fabricius (currently Digitonthophagus gazella or Onthophagus gazella; Insecta, Coleoptera, Scarabaeidae): proposed conservation of usage of the specific name by designation of a neotype. - Bulletin of Zoological Nomenclature 74: 78-87. https://www.biotaxa.org/bzn/ article/view/32944.

Génier, F. \& P. Moretto, 2017. Digitonthophagus Balthasar, 1959: taxonomy, systematics, and morphological phylogeny of the genus revealing an African species complex (Coleoptera: Scarabaeidae: Scarabaeinae). Zootaxa 4248: 1-110. doi: 10.11646/zootaxa.4248. 1.1.

Geoffroy, E.L., 1762. Histoire abrégée des insectes qui se trouvent aux environs de Paris; dans laquelle ces animaux: sout rangés suivant un ordre méthodique. Tome première. - Durand, Paris, France, xxviii + 523 pp. + 22 pls. https://www.biodiversitylibrary.org/ page/ 14715647.

Germann, C., 2016. First record of the neozoic species Naupactus cervinus Boheman, 1840 (Coleoptera,
Curculionidae, Entiminae) for Switzerland with a short review of its spreading and food plants. - Mitteilungen der Schweizerischen Entomologischen Gesellschaft 89: 1-5. https://www.e-periodica.ch/cntmng?pid=seg $-001: 2016: 89:: 318$.

Germar, E.F., 1823 [1824]. Coleopterorum species novae aut minus cognitae, descriptionibus illustratae. - J.C. Hendelii et filii, Halle, Germany, xxiv +624 pp. +2 pls. https://www.biodiversitylibrary.org/page/53456291.

Gidaspow, T., 1963. The genus Calosoma in Central America, the Antilles, and South America (Coleoptera, Carabidae). - Bulletin of the American Museum of Natural History 124: 275-314. http://hdl.handle .net/2246/1214.

Gillet, J.J.E., 1911. Coleopterorum Catalogus auspiciis et auxilio. Pars 38. Fam. Scarabaeidae, Subfam. Coprinae I. - W. Junk, Berlin, Germany, 100 pp.

Gillett, M.P.T., 2020. ResearchGate profile. - available at https://www.researchgate.net/profile/Michael_Gillett.

Gillett, C.P.D.T. \& M.P.T. Gillett, 2015. The Dynastinae of the island of Saba, Dutch Caribbean (Coleoptera: Scarabaeidae). - Insecta Mundi 433: 1-9. https://jour nals.flvc.org/mundi/article/view/0433.

Gillett, M.P.T. \& C.P.D.T. Gillett, 2019. Nemocephalus monilis (Fabricius, 1787) (Coleoptera: Curculionoidea: Brentidae), an apparently recent arrival and effective colonizer of the Oceanic Island of Saba, Dutch Caribbean. - Coleopterists Bulletin 73: 871-874. doi: 10.1649/0010-065X-73.4.871.

Gillett, C.P.D.T., A. Crampton-Platt, M.J.T.N. Timmermans, B.H. Jordal, B.C. Emerson \& A.P. Vogler, 2014. Bulk de novo mitogenome assembly from pooled total DNA elucidates the phylogeny of weevils (Coleoptera: Curculionoidea). - Molecular Biology and Evolution 31: 2223-2237. doi: 10.1093/molbev/msu 154.

Gilmour, E.F., 1963a. Some Caribbean Coleoptera Cerambycidae. - Studies on the Fauna of Curaçao and other Caribbean Islands 18: 75-102. https://repository.naturalis.nl/pub/506041.

Gilmour, E.F., 1963b. On the Neotropical Acanthocinini (Col., Cerambycidae, Lamiinae): Some Caribbean genera and species. - Studies on the Fauna of Curaçao and other Caribbean Islands 17: 57-96. https://repository .naturalis.nl/pub/506131.

Gilmour, E.F., 1968. The Coleoptera Cerambycidae of Curaçao, Bonaire and Aruba. - Studies on the Fauna of Curaçao and other Caribbean Islands 25: 83-179. https:// repository.naturalis.nl/document/549968.

Gimmel, M.L., 2013. Genus-level revision of the family Phalacridae (Coleoptera: Cucujoidea). - Zootaxa 3605: 1-147. doi: 10.11646/zootaxa.3605.1.1.

Girón, J.C. \& N.M. Franz, 2010. Revision, phylogeny and historical biogeography of the genus Apodrosus Marshall, 1922 (Coleoptera: Curculionidae: Entiminae). - Insect Systematics \& Evolution 41: 339-414. doi: 10.1163/187631210X538799.

Girón, J.C., C.W. O’Brien \& M.C. Rose-Smyth, 2018. On the West Indian weevil genus Lachnopus Schönherr, 
1840 (Coleoptera: Curculionidae: Entiminae): descriptions of six new species, a proposal for species-groups, and an annotated checklist. - Zootaxa 4423: 1-85. doi: 10.11646/zootaxa.4423.1.1.

Gistel, J.N.F.X., 1848a. Faunula monacensis cantharologica (Fortsetzung). - Isis von Oken 1848: [4-6].

Gistel, J.N.F.X., 1848b. Faunula monacensis cantharologica (Fortsetzung). - Isis von Oken 1848: [10-11].

Gmelin, J.F., 1790. Caroli a Linné Systema Naturae per regna tria naturae, secundum classes, ordines, genera, species, cum characteribus, differentiis, synonymis, locis. Editio decima tertia, aucta, reformata. Tom. I. Pars IV. - Georg. Emanuel. Beer, Lipsiae. pp. 1517-2224. https://www.biodiversitylibrary.org/page/ 2897587.

Gohli, J., T. Selvarajah, L.R. Kirkendall \& B.H. Jordal, 2016. Globally distributed Xyleborus species reveal recurrent intercontinental dispersal in a landscape of ancient worldwide distributions. - BMC Evolutionary Biology 16: 37. doi: 10.1186/s12862-0160610-7.

González, G., 2015. Beetles (Coleoptera) of Peru: A survey of the families: Coccinellidae. - Journal of the Kansas Entomological Society 88: 229-236. doi: 10.2317/ kent-88-02-229-236.1.

González, G., R.L. Bermúdez \& T. Kondo, 2012. First report of Delphastus quinculus Gordon and Diomus seminulus (Mulsant) (Coleoptera: Coccinellidae) feeding on eggs and first-instar nymphs of Crypticerya multicicatrices Kondo and Unruh (Hemiptera: Monophlebidae). - Insecta Mundi 268: 1-6. https://journals.flvc.org/ mundi/article/view/0268.

Gordon, R.D., 1972. A review of the genus Nephaspis Casey and a comparison with the genus Clitostethus Weise (Coleoptera: Coccinellidae). - Revista de Agricultura (Piracicaba) 47: 145-154. http://www.revistadeagricultura.org.br/index.php/revistadeagricultura/ article/view/2120.

Gordon, R.D., 1976. The Scymnini (Coleoptera: Coccinellidae) of the United States and Canada: key to genera and revision of Scymnus, Nephus and Diomus. - Bulletin of the Buffalo Society of Natural Sciences 28: 1-362.

Gordon, R.D., 1978. West Indian Coccinellidae II (Coleoptera): some scale predators with keys to genera and species. - Coleopterists Bulletin 32: 205-218. https:// www.jstor.org/stable/3999871.

Gordon, R.D., 1985. The Coccinellidae (Coleoptera) of America north of Mexico. - Journal of the New York Entomological Society 93: 1-912. https://www.jstor .org/stable/25009452.

Gordon, R.D., 1987. A catalogue of the Crotch collection of Coccinellidae (Coleoptera). - Occasional Papers on Systematic Entomology 3: 1-46.

Gordon, R.D., 1993. Stethorus nigripes Kapur new to North America, and a new synonym in Stethorus Weise (Coleoptera: Coccinellidae). - The Southwestern Entomologist 18: 67-68.

Gordon, R.D., 1994. South American Coccinellidae (Coleoptera) Part III: Taxonomic revision of the Western
Hemisphere genus Delphastus Casey. - Frustula Entomologica 17: 71-133.

Gordon, R.D., 1997. South American Coccinellidae (Coleoptera). Part V: A taxonomic revision of the genus Nephaspis Casey. - Frustula Entomologica 19: 1-50.

Gordon R.D. \& C. Canepari, 2008. South American Coccinellidae (Coleoptera). Part XI: A systematic revision of Hyperaspidini (Hyperaspidinae). - Annali del Museo Civico di Storia Naturale Giacomo Doria 99: 245-512.

Gordon, R.D. \& E.A. Chapin, 1983. A revision of the New World species of Stethorus Weise (Coleoptera: Coccinellidae). - Transactions of the American Entomological Society 109: 229-276. https://www.jstor .org/stable/25078324.

Gordon, R.D. \& D.J. Hilburn, 1990. The Coccinellidae (Coleoptera) of Bermuda. - Journal of the New York Entomological Society 98: 265-309. https://www.jstor .org/stable/25009841.

Gordon, R.D. \& R. Pittino, 1992. Current status of the American genera and species of Psammodiini (Coleoptera: Scarabaeidae: Aphodiinae). - Coleopterists Bulletin 46: 260-273. https://www.jstor.org/stable/ 4008816.

Gory, H.L., 1833. Centurie de carabiques nouveaux. - Annales de la Société Entomologique de France 2, 168-247. https://www.biodiversitylibrary.org/page/32 293860.

Gory, H. \& A. Percheron, 1834. Monographie des cétoines et genres voisins, formant, dans les familles naturelles de Latreille, la division des scarabées mélitophiles. Livraison 2: pp. 65-106 + 5 pls. - Ballière, Paris, France. https://www.biodiversitylibrary.org/page/9447255.

Gory, H. \& A. Percheron, 1835. Monographie des cétoines et genres voisins, formant, dans les familles naturelles de Latreille, la division des scarabées mélitophiles. Livraison 9: pp. 235-? + 5 pls. - Ballière, Paris, France. https://www.biodiversitylibrary.org/page/9447427.

Grant, S. \& M. Turcatel, 2020. Field Museum of Natural History (Zoology) Insect, Arachnid and Myriapod Collection. Version 12.18. Field Museum. - Occurrence dataset. https://doi.org/10.15468/0ywfpc accessed via GBIF.org on 2020-02-02.

Greenstone, M.H., N.J. Vandenberg \& J.H. Hu, 2011. Barcode haplotype variation in North American agroecosystem lady beetles (Coleoptera: Coccinellidae). - Molecular Ecology Resources 11: 629-637. doi: 10.1111/j.1755-0998.2011.03007.x.

"Greensxm", 2019. Record with photo on iNaturalist. https://www.inaturalist.org/observations/36035824.

Grey, L. \& A.D. Smith, 2020. A matrix-based revision of the genus Hypogena Dejean, 1834 (Coleoptera: Tenebrionidae). - Zooataxa 4780: 201-258. doi: 10.11646/ zootaxa.4780.2.1.

Grimm, R., A.D. Smith, W.E. Steiner \& F. Wachtel, 2018. New synonymy and new combination in Hypogena Dejean (Coleoptera: Tenebrionidae). - Spixiana 41: 210.

Grouvelle, A., 1916. Mémoires entomologiques. Études sur les coléoptères. Premier fascicule. - Société Entomologique de France, Paris, France, 80 pp. 
Grouvelle, A. \& A. Léveillé, 1902. Voyage de M. le dr. Ed. Bugnion au Vénézuela, en Colombie et aux Antilles. Coléoptères Clavicornes. - Annales de la Société Entomologique de France 71: 461-467. https://www.biodiversitylibrary.org/page/8251865.

Grouvelle, A. \& A. Léveillé,1903. Voyage de M. le dr. Ed. Bugnion au Venezuela, en Colombie et aux Antilles. Coléoptères ClavicornesI. - Annales de la Société Entomologique de France 72: 460, Planche VI. https:// www.biodiversitylibrary.org/page/8248517.

Guérin, F.É., 1829. Iconographie du règne animal de G. Cuvier, ou représentation d'après nature de l'une des espèces les plus remarquables et souvent non figurées de chaque genre d'animaux. Avec un texte descriptif mis au courant de la science. Ouvrage pouvant servir d'atlas à tous les traités de zoologie. II. Planches des animaux invertébrés. Insectes. [livraison 3]: pl. 8-10. - J.B. Baillière, Paris, France. https://www.biodiversitylibrary. org/page/27813861.

Guérin-Méneville, F.É., 1837. Iconographie du règne animal de G. Cuvier, ou représentation d'après nature de l'une des espèces les plus remarquables et souvent non figurées de chaque genre d'animaux. Avec un texte descriptif mis au courant de la science. Ouvrage pouvant servir d'atlas à tous les traités de zoologie. II. Planches des animaux invertébrés. Insectes. [livraison 44]: pl. 41. - J.B. Baillière, Paris, France. https://www.biodiversity library.org/page/27813935.

Guérin-Méneville, F.É., 1844. Iconographie du règne animal de G. Cuvier, ou représentation d'après nature de l'une des espèces les plus remarquables et souvent non figurées de chaque genre d'animaux. Avec un texte descriptif mis au courant de la science. Ouvrage pouvant servir d'atlas à tous les traités de zoologie. Insectes. J.B. Baillière, Paris, France. https://books.google.nl/ books/about/Iconographie_du_R\%C3\%A8gne_Ani mal_de_G_Cuvie.html?id=De1ZAAAAcAAJ\&redir _esc $=$ y.

Gundersen, R., 1977. New species and taxonomic changes in the genus Enochrus (Coleoptera: Hydrophilidae). Coleopterists Bulletin 31: 251-272. https://www.jstor .org/stable/3999966.

Gustafson, G.T. \& K.B. Miller, 2013. On the family- and genus-series nomina in Gyrinidae Latreille, 1810 (Coleoptera, Adephaga) . - Zootaxa 3731: 77-105. doi: 10.11646/zootaxa.3731.1.3.

Gustafson, G.T. \& A.E.Z. Short, 2017. Review of the whirligig beetle genus Gyrinus of Venezuela (Coleoptera: Gyrinidae). - Acta Entomologica Musei Nationalis Pragae 57: 479-520. doi: 10.1515/aemnp-20170087.

Gyllenhal, L., 1806. Carabus sinuatus. - In: C.J. Schönherr, Synonymia insectorum oder: Versuch einer Synonymie aller bisher bekannten Insecten; nach Fabricii Systema Eleutheratorum geordnet. Mit Berichtigungen und Anmerkungen, wie auch Beschreibungen neuer Arten und illuminirten Kupfern. Erster Band. Eleutherata oder Käfer. Erster Theil. Lethrus... Scolytes: pp. 203. H.A. Nordström, Stockholm, Sweden. https://www .biodiversitylibrary.org/page/42218764.
Gyllenhal, L., 1808a. Cryptophagus Forsströmii. - In: C.J. Schönherr, Synonymia insectorum oder: Versuch einer Synonymie aller bisher bekannten Insecten; nach Fabricii Systema Eleutheratorum \&c. geordnet. Mit Berichtigungen und Anmerkungen, wie auch Beschreibungen neuer Arten und illuminirten Kupfern. Erster Band. Eleutherata oder Käfer. Zweiter Theil. Spercheus... Cryptocephalus: p. 100. C.F. Marquard, Stockholm, Sweden.

Gyllenhal, L., 1808b. Nitidula strigosa. - In: C.J. Schönherr, Synonymia insectorum oder: Versuch einer Synonymie aller bisher bekannten Insecten; nach Fabricii Systema Eleutheratorum \&c. geordnet. Mit Berichtigungen und Anmerkungen, wie auch Beschreibungen neuer Arten und illuminirten Kupfern. Erster Band. Eleutherata oder Käfer. Zweiter Theil. Spercheus... Cryptocephalus: pp. 140-141. C.F. Marquard, Stockholm, Sweden. https://www.biodiversitylibrary.org/ page/42206733.

Gyllenhal, L., 1808c. Nitidula lusca. - In: C.J. Schönherr, Synonymia insectorum oder: Versuch einer Synonymie aller bisher bekannten Insecten; nach Fabricii Systema Eleutheratorum \&c. geordnet. Mit Berichtigungen und Anmerkungen, wie auch Beschreibungen neuer Arten und illuminirten Kupfern. Erster Band. Eleutherata oder Käfer. Zweiter Theil. Spercheus... Cryptocephalus: p. 140. C.F. Marquard, Stockholm, Sweden. https://www.biodiversitylibrary.org/page/42206733.

Gyllenhal, L., 1808d. Insecta Suecica, Classis I. Coleoptera sive Eleuterata. Tomus I. [Pars I.]. - F.J. Leverentz, Scaris, viii + 572 pp. https://www.biodiversitylibrary.org/ page/ 16226580 .

Gyllenhal, L., 1813. Insecta Suecica, Classis I. Coleoptera sive Eleuterata. Tomi I. Pars III. - F.J. Leverentz, Skara, Sweden, 730 pp. https://www.biodiversitylibrary.org/ page/15867572.

Gyllenhal, L., 1817. Elater amplicollis. - In: C.J. Schönherr, Appendix ad C.J. Schönherr Synonymiam insectorum. Tom. I. Part. 3. Sistens descriptiones novarum specierum: pp. 141-142. Lewerentz, Skara, Sweden. https://www.biodiversitylibrary.org/page/42207541.

Gyllenhal, L., 1827. Insecta svecica. Classis I. Coleoptera sive Eleuterata. Tomus I. Pars IV. - F. Fleischer, Leipzig, Germany, viii + 761 pp. https://www.biodiversitylibrary .org/page/9320496.

Gyllenhal, L., 1833. Apion pilosum. - In: C.J. Schoenherr, Genera et species curculionidum, cum synonymia hujus familiae; Species novae aut hactenus minus cognitae, descriptionibus a Dom. Leonardo Gyllenhal, C.H. Boheman, et entomologis aliis illustratae. Tomus primus. Pars prima: p. 258. Roret, Paris, France.

Gyllenhal, L., 1834. Ptilopus valgus. - In: C.J. Schoenherr, Genera et species curculionidum, cum synonymia hujus familiae; Species novae aut hactenus minus cognitae, descriptionibus a Dom. Leonardo Gyllenhal, C.H. Boheman, et entomologis aliis illustratae. Tomus secundus. Pars prima: p. 41, Roret, Paris, France. https:// www.biodiversitylibrary.org/page/9785471.

Gyllenhal, L., 1835a. Anthonomus macromalus. - In: C.J. Schoenherr, Genera et species curculionidum, cum Downloaded from Brill.com04/26/2023 08:17:17AM via free access 
synonymia hujus familiae; Species novae aut hactenus minus cognitae, descriptionibus a Dom. Leonardo Gyllenhal, C.H. Boheman, et entomologis aliis illustratae. Tomus tertius. Pars prima: pp. 352-353. Roret, Paris, France. https://www.biodiversitylibrary .org/page/9442714.

Gyllenhal, L., 1835b. Anthonomus infirmus. - In: C.J. Schoenherr, Genera et species curculionidum, cum synonymia hujus familiae; Species novae aut hactenus minus cognitae, descriptionibus a Dom. Leonardo Gyllenhal, C.H. Boheman, et entomologis aliis illustratae. Tomus tertius. Pars prima: pp. 353-354. Roret, Paris, France. https://www.biodiversitylibrary .org/page/9442715.

Gyllenhal, L., 1835c. Anthonomus argentatus. - In: C.J. Schoenherr, Genera et species curculionidum, cum synonymia hujus familiae; Species novae aut hactenus minus cognitae, descriptionibus a Dom. Leonardo Gyllenhal, C.H. Boheman, et entomologis aliis illustratae. Tomus tertius. Pars prima: p. 343. Roret, Paris, France. https://www.biodiversitylibrary.org/page/9442705.

Gyllenhal, L., 1838. Scyphophorus acupunctatus. - In: C.J. Schoenherr, Genera et species curculionidum, cum synonymia hujus familiae; Species novae aut hactenus minus cognitae, descriptionibus a Dom. Leonardo Gyllenhal, C.H. Boheman, et entomologis aliis illustratae. Tomus quartus. Pars secunda: p. 857. Roret, Paris, France.

Haack, R.A., 2001. Intercepted Scolytidae (Coleoptera) at U.S. ports of entry: 1985-2000. - Integrated Pest Management Reviews 6: 253-282. doi: 10.1023/A:1025715200538.

Haber, E., 2019. Records with photo on iNaturalist. https://www.inaturalist.org/observations/27313757, https://www.inaturalist.org/observations/35015178, https://www.inaturalist.org/observations/22624666, https://www.inaturalist.org/observations/22624665.

Hagedorn, M., 1912. Borkenkäfer (Ipidae) welche in Kautschukbäumen leben. - Revue Zoologique Africaine 1: 336-346. https://www.biodiversitylibrary.org/ page/32992214.

Hagstrum, D. \& B. Subramanyam, 2009. Stored-product insect resource. - AACC International Inc., St. Paul, MN, USA, 509 pp.

Halewijn, R. van, L.W.G. Higler \& A.L. Spaans, 1992. Ecologisch onderzoek Bubali-plas, Aruba. - RIN-rapport 92/30, DLO-Instituut voor Bos- en Natuuronderzoek, Arnhem, The Netherlands, 77 pp. + 14 tabs. + 1 app. https://library.wur.nl/WebQuery/wurpubs/ fulltext/384655.

Hansen, M., 1999. Taxonomic changes in the genera Oosternum Sharp and Paroosternum Scott (Coleoptera: Hydrophilidae). - Entomologica Scandinavica 30: 241-242. doi: 10.1163/187631200X00084.

Harold, E., 1867a. Diagnosen neuer Coprophagen. Coleopterologische Hefte 1: 76-83. https://www.biodiversitylibrary.org/page/16069331.

Harold, E., 1867b. Die chilensischen Aphodiden. -Berliner Entomologische Zeitschrift 11: 278-282. https:// www.biodiversitylibrary.org/page/9215546.
Harold, E., 1869. Diagnosen neuer Coprophagen. Coleopterologische Hefte 5: 95-104. https://www. biodiversitylibrary.org/page/16069770.

Hart, C.J. \& M.A. Ivie, 2016. A revision of the genus Diastolinus Mulsant and Rey (Coleoptera: Tenebrionidae). - Coleopterists Bulletin 70: 485-540. doi: 10.1649/0010-065X-70.3.485.

Háva, J., 2003. World catalogue of the Dermestidae. Studie a Zprávy Oblastního Muzea Praha-východ v Brandýse nad Labem a Staré Boleslavi, Supplementum 1: 1-196.

Háva, J., 2015. World Catalogue of Insects., Vol. 13. Dermestidae (Coleoptera). - Brill, Leiden, The Netherlands, $419 \mathrm{pp}$.

Háva, J., 2016. Designations of Anthrenus serraticornis Fabricius, 1792 and Anthrenus denticornis Fabricius, 1792 lectotypes and proposal of a new synonym (Coleoptera: Dermestidae: Megatominae). - Folia Heyrovskyana Ser. A 24: 1-3. https://foliaseriesa.cz/pdf/2016 $-2 / \mathrm{H} \% \mathrm{C} 3 \% \mathrm{~A} 1 \mathrm{va} \% 201-3$.pdf.

Heatwole, H., R. Levins \& M.D. Byer, 1981. Biogeography of the Puerto Rican Bank. - Atoll Research Bulletin 251: 1-55. doi: 10.5479/si.00775630. 251.1 .

Herbst, J.F.W., 1790. Natursystem aller bekannten in- und ausländischen Insekten als eine Fortsetzung der von Büffonschen Naturgeschichte. Der Käfer dritter Theil. - Pauli, Berlin, Germany, xiv + 325 pp. + pls 21-34. https://www.biodiversitylibrary.org/page/57680710.

Herbst, J.F.W., 1797. Natursystem aller bekannten in- und ausländischen Insekten als eine Fortsetzung der von Büffonschen Naturgeschichte. Der Käfer siebenter Theil. - Pauli, Berlin, Germany, xi + 346 pp. + pls 96-116. https://www.biodiversitylibrary.org/page/577 55101.

Hewitt, S., 2017. Records with photo on iNaturalist. https://www.inaturalist.org/observations/6027919, https://www.inaturalist.org/observations/6099546.

Hewitt, S., 2018. Record with photo on iNaturalist. https://www.inaturalist.org/observations/11007144, https://www.inaturalist.org/observations/11297841.

Hewitt, S., 2019. Record with photo on iNaturalist. https://www.inaturalist.org/observations/21904966, https://www.inaturalist.org/observations/22368441, https://www.inaturalist.org/observations/22325035, https://www.inaturalist.org/observations/22277252, https://www.inaturalist.org/observations/22034153.

Hielkema, A.J., 2017. Some corrections and remarks regarding the nomenclature of Neotropical Athyreini, Passalini, Phanaeini, Rutelini, Cyclocephalini, Dynastini and Oryctini (Coleoptera: Scarabaeoidea). Insecta Mundi 561: 1-18. https://journals.flvc.org/ mundi/article/view/0561.

Hielkema, A.J. \& M.A. Hielkema, 2019. An annotated checklist of the Scarabaeoidea (Insecta: Coleoptera) of the Guianas. - Insecta Mundi 732: 1-306. https:// journals.flvc.org/mundi/article/view/117774/115798.

Higler, L.W.G. \& R. van Halewijn, 1991. Limnology of a tropical sewage pond. - Verhandlungen der Internationale Vereinigung für Theoretische und Angewandte 
Limnologie 24: 2163-2167. doi: 10.1080/03680770. 1989.11899917.

Hippolyte, J.-C. \& P. Mann, 2011. Neogene-Quaternary tectonic evolution of the Leeward Antilles islands (Aruba, Bonaire, Curaçao) from fault kinematic analysis. - Marine and Petroleum Geology 28: 259-277. doi: 10.1016/j.marpetgeo.2009.06.010.

Hodges, R.W., 1991. Obituary. John F. Gates Clarke (1905-1990). - Journal of the Lepidopterists' Society 45: 75-81.

Hoelmer, K.A. \& C.H. Pickett, 2003. Geographic origin and taxonomic history of Delphastus spp. (Coleoptera: Coccinellidae) in commercial culture. - Biocontrol Science and Technology 13: 529-535. doi: 10.1080/0958315031000141018.

Holleman, W., 1952. Mimus, de Chuchubi bekijkt Curaçao. - R.K. Boekhandel St. Augustinus, Curaçao, Netherlands Antilles, 128 pp.

Holthuis, L.B., 1959. H.E. van Rijgersma - a little-known naturalist of St. Martin (Netherlands Antilles). Studies on the Fauna of Curaçao and other Caribbean Islands 9: 69-78. http://www.repository.naturalis.nl/ document/549854.

Holthuis, L.B., 1961. Nadere gegevens betreffende H.E. van Rijgersma. - Nieuwe West-Indische Gids 41: 166167. https://www.jstor.org/stable/41848950.

Hope, F.W., 1840. The coleopterist's manual, part the third, containing various families, genera, and species, of beetles, recorded by Linneus and Fabricius. Also, descriptions of newly discovered and unpublished insects. - J.C. Bridgewater and Bowdery \& Kerby, London, UK, [5] + 191 pp. + 3 pls.

Hopkins, A.D., 1902. A new genus of scolytids from Florida. - Proceedings of the Entomological Society of Washington 5: 34-38. https://www.biodiversitylibrary .org/page/2347020.

Hopkins, A.D., 1915. Classification of the Cryphalinae with descriptions of new genera and species. United States Department of Agriculture Report 99: 1-69. https://www.biodiversitylibrary.org/page/4215 6131.

Horn, G.H., 1873a. Synopsis of the Histeridae of the United States. - Proceedings of the American Philosophical Society 13: 273-360. https://www.biodiversitylibrary.org/page/7046232.

Horn, G.H., 1873b. Revision of the Bruchidae of the United States. - Transactions of the American Entomological Society 4: 311-342. https://www.biodiversitylibrary.org/page/7522830.

Horn, G.H., 1880. Revision of the Nitidulidae of the United States. - Transactions of the American Entomological Society and Proceedings of the Entomological Section of the Academy of Sciences 7: 267-340. https://www.biodiversitylibrary.org/page/ 7727713 .

Horn, G.H., 1895. Studies in Coccinellidae. - Transactions of the American Entomological Society 22: 81-114. https://www.biodiversitylibrary.org/page/7521358.

Horn, W., 1925. Über 16 alte und neue Cicindeliden der Welt. - Entomologische Blätter 21: 131-139.
Horn, W., 1926. Carabidae: Cicindelinae. - In: Junk, W. \& S. Schenkling (Eds), Coleopterorum Catalogus. Pars 86, W. Junk, Berlin, Germany, 345 pp.

Horn, W. \& I. Kahle, 1935. Über entomologische Sammlungen, Entomologen \& Entomo-Museologie (Ein Beitrag zur Geschichte der Entomologie). Teil I. I. Kapitel: Sammlungen, welche ihren Eigentümer gewechselt haben (nebst Angaben über Ausbeuten von Expeditionen, Privat-Sammlern und Händlern). - Entomologische Beihefte aus Berlin-Dahlem 2: 1-160. https://www.zobodat.at/pdf/Ent-Beih-Berlin -Dahlem_2_0001-0160.pdf.

Hornung, E.G., 1842. Ueber einige in den Betelnüssen vorkommende Käfer. -Entomologische Zeitung, Stettin, 3: 115-117. https://www.biodiversitylibrary.org/ page/34705388.

Howden, H.F., 1970. Jamaican Scarabaeidae: Notes and descriptions (Coleoptera). - Canadian Entomologist 102: 1-15. doi: 10.4039/Ent1021-1.

Hüdepohl, K.-E., 1979. Revision der Gattung Oxymerus Serville (Coleoptera, Cerambycidae, Cermabycinae, Trachyderini). - Entomologische Arbeiten aus dem Museum G. Frey 28: 9-74. https://www.biodiversitylibrary.org/page/45975693.

Hüdepohl, K.-E., 1985. Revision der Trachyderini (Coleoptera, Cerambycidae, Cerambycinae). - Entomologische Arbeiten aus dem Museum G. Frey 33-34: 1-167. https://www.biodiversitylibrary.org/ page/49596956.

Hustache, A., 1929. Curculionides de la Guadeloupe. Première partie. - Faune des Colonies Françaises 3: 165-267.

Hutson, J.C., 1917. Insect pests in British Guiana in 1916. - The Agricultural News 16: 266-267. https://www .biodiversitylibrary.org/page/4660890.

ICZN, 1957. Opinion 474. Determination of the dates to be assigned for the purposes of the Law of Priority to the names published in Dru Drury's Illustrations of Natural History in the period 1770-1782. - Opinions and Declarations Rendered by the International Commission on Zoological Nomenclature 16: 297-306. https://www.biodiversitylibrary.org/page/ 34657252 .

ICZN, 1999. International Code of Zoological Nomenclature. Fourth Edition. - The International Trust for Zoological Nomenclature, London, UK, 306 pp. https://www.iczn.org/the-code/the-international-code-of-zoological-nomenclature/the-code -online/.

Iglesias, F., 1914. Ipidae brazileiros. Diagnose de duas expecies novas. - Revista do Museu Paulista 9: 128132. https://www.biodiversitylibrary.org/page/1080 0522 .

Imhoff, L., 1856. Versuch einer Einführung in das Studium der Koleoptern. II. Besonderer Theil. - Schweighauser, Basel, Switzerland, 272 pp.

INCEE, 2016. Populations légales en vigueur à compter du 1er janvier 2016. - Institut National de la Statistique et des Études Économiques, Paris, France, v-vii +1 p. 
INPN, 2020. Inventaire National du Patrimoine Naturel. Digital publication available at https://inpn.mnhn .fr/.

Irmler, U. 2014. The Neotropical species of the genus Osoriellus Fagel, 1959 (Coleoptera: Staphylinidae: Osoriinae). - Beiträge zur Entomologie 64 (2): 231-354. doi: 10.21248/contrib.entomol.64.2.231354.

Irmler, U. 2016. Three new species of Molosoma Say, 1831 from French Guiana, and a new generic synonymy (Coleoptera: Staphylinidae: Osoriinae). - Koleopterologische Rundschau 86: 139-145.

Ivie, M.A., 1985. Nomenclatural notes on West Indian Elaphidiini (Coleoptera: Cerambycidae). - Pan-Pacific Entomologist 61: 303-314. https://www.biodiversity library.org/page/56199761.

Ivie, M.A. \& M.F. Geiser, 2014. The status of Tylocerus crassicornis (Dalman, 1823), type species of Tylocerus Dalman, 1823 (Coleoptera: Cantharidae: Silinae). - Coleopterists Bulletin 68: 111-114. doi: 10.1649/0010-065X-68.1.111.

Ivie, M.A. \& Ch.J. Hart, 2016. Redefinition of Diastolinus Mulsant and Rey, with a review of West Indian blapstinoid genera (Coleoptera: Tenebrionidae: Opatrini). - Coleopterists Bulletin 70: 447-481. doi: 10.1649/0010-065X-70.3.447.

Ivie, M.A., K.A. Marske, I.A. Foley, K.A. Guerrero \& L.L. Ivie, 2008a. Invertebrates of the Centre Hills and Montserrat, with an emphasis on beetles. - In: R.P. Young (Ed.), A Biodiversity Assessment of the Centre Hills, Montserrat. Durrell Conservation Monographs 1: 56-89. http://www.mvmnh.org/documents/ Durrell_Cons_Monograph_Ivie_et_al.pdf.

Ivie, M.A., K.A. Marske, I.A. Foley, K.A. Guerrero \& L.L. Ivie, 2008b. Appendix 2. Species lists of the beetles, non-beetle hexapods and non-hexapod invertebrates of Montserrat. - In: R.P. Young (Ed.), A Biodiversity Assessment of the Centre Hills, Montserrat. Durrell Conservation Monographs 1: 237-311. http://www.mvmnh.org/documents/Durrell_Cons _Monograph_Ivie_et_al.pdf.

Ivie, M.A., D.S. Sikes, C.A. Maier \& R.C. Winton, 2009. The Coleoptera of Saba, West Indies. - Poster presented at the Entomological Society of America Annual Meeting 2009. Indianapolis, IN, USA..

Ivie, M.A., N.P. Lord, I.A. Foley \& S.A. Ślipiński, 2016. Colydiine genera (Coleoptera: Zopheridae: Colydiinae) of the New World: a key and nomenclatural acts 30 years in the making. - Coleopterists Bulletin 70: 755-788. doi: 10.1649/0010-065X-70.4.755.

Iwan, D., 1995. Revision of the genus Opatrinus Dejean, 1821 (Coleoptera: Tenebrionidae: Platynotini). Genus 6 (1): 1-90.

Jacquelin Du Val, C., 1852. Description de deux genres nouveaux et de plusieurs espèces nouvelles de coléoptères propres a la faune française. - Annales de la Société Entomologique de France Ser. 2, 10: 695718. https://www.biodiversitylibrary.org/page/855 6369.

Jacquelin Du Val, P.N.C., 1857. Partie descriptive. Insectes. Ordre des Coléoptères. - In: M. Ramón de la
Sagra (Ed.), Histoire physique, politique et naturelle de l'Ile de Cuba 7: 1-328. Arthus Bertrand, Paris, France. https://www.biodiversitylibrary.org/page/24480339.

Jacquelin Du Val, C., 1858. Cybocéphalites. - In: Manuel entomologique. Genera des coléoptères d'Europe comprenant leur classification en familles naturelles, la description de tous les genres, des tableaux synoptiques destinés à faciliter l'étude, le catalogue de toutes les espèces, de nombreux dessins au trait de charactères et plus de treize cents types représentant un ou plusieurs insectes de chaque genre dessinés et peints d'après nature avec le plus grand soin par M. Jules Migneaux. Tome deuxième: [livr. 58-67]: pp. 151-152. A. Deyrolle, Paris, France. https://www.biodiversitylibrary .org/page/27342969.

Jacquelin du Val, P.N.C., 1862. Catalogue de la famille des Ténébrionides. - In: Manuel Entomologique. Genera des coléoptères d'Europe comprenant leur classification en familles naturelles, la description de tous les genres, des tableaux synoptiques destinés à faciliter l'étude, le catalogue de toutes les espèces, de nombreux dessins au trait de caractères et plus de quinze cents types représentant un ou plusieurs insectes de chaque genre dessinés et peints d'après nature avec le plus grand soin par M. Jules Migneaux. Catalogue.: pp. 169-184. A. Deyrolle, Paris, France. https://www.biodiversityli brary.org/page/25213868.

Jelínek, J. \& P. Audisio, 2007. Nitidulidae. - In: I. Löbl \& A. Smetana (Eds), Catalogue of Palaearctic Coleoptera., Vol. 4. Elateroidea, Derodontoidea, Bostrichoidea, Lymexyloidea, Cleroidea, Cucujoidea: pp. 459-491. Apollo Books, Stenstrup, Denmark.

Jelínek, J. \& A. Nicholas Evans, 1982. Species of the genus Conotelus from the West Indies (Coleoptera, Nitidulidae). - Acta Entomologica Bohemoslovaca 79: 226-237.

Jesse, W.A.M., J. Molleman, O. Franken, M. Lammers, M.P. Berg, J.E. Behm, M.R. Helmus \& J. Ellers, 2020. Disentangling the effects of plant species invasion and urban development on arthropod community composition. - Global Change Biology 26: 3294-3306. doi: 10.1111/gcb.15091.

Johnson, C.D., 1977. Two new species of Acanthoscelides from North America and new host records from Desmanthus and Hoffmanseggia (Coleoptera: Bruchidae). - Pan-Pacific Entomologist 53: 60-73. https://www .biodiversitylibrary.org/page/56113579.

Johnson, C.D., 1983. Ecosystematics of Acanthoscelides (Coleoptera: Bruchidae) of Southern Mexico and Central America. - Miscellaneous Publications of the Entomological Society of America 56: 1-248.

Johnson, C.D., 1990. Systematics of the seed beetle genus Acanthoscelides (Bruchidae) of northern South America. - Transactions of the American Entomological Society 116: 297-618. https://www.jstor.org/ stable/25078519.

Johnson, C.D., 1995. New host records from Latin America and new synonymy for Stator limbatus (Horn) and S. cearanus (Pic) (Coleoptera: Bruchidae). - Coleopterists Bulletin 49: 319-326. https://www.jstor.org/ stable/400901079.toaded from Brill.com04/26/2023 08:17:17AM 
Johnson, N. \& J. Cora, 2020. C.A. Triplehorn Insect Collection (OSUC), Ohio State University. Museum of Biological Diversity, The Ohio State University Occurrence dataset. doi: 10.15468/efb $17 f$ accessed via GBIF.org on 2020-02-02.

Johnson, A.J., J. Hulcr, M. Knížek, T.H. Atkinson, M.Y. Mandelshtam, S.M. Smith, A.I. Cognato, S. Park, Y. Li \& B.H. Jordal, 2020. Revision of the bark beetle genera within the former Cryphalini (Curculionidae: Scolytinae). - Insect Systematics and Diversity 4: 1-81. doi: $10.1093 /$ isd/ixaa002.

Jonge Poerink, W.H., 1953. Caribbean tiger beetles of the genus Cicindela. - Studies on the Fauna of Curaçao and other Caribbean Islands 4: 120-143. http://www .repository.naturalis.nl/document/549858.

Kairo, M.T.K., V.F. Lopez, G.V.Pollard \& R. Hector, 2001. Biological control of the coconut whitefly, $\mathrm{Al}$ eurodicus pulvinatus, in Nevis. - Biocontrol News and Information 22: 45N-50N. http://cabweb.org/PDF/ BNI/Control/BNIra59.pdf.

Kalshoven, L.G.E., 1963. Ecological data on some neotropical Scolytidae, Platypodidae and Bostrychidae (Coleoptera), mainly of Surinam. - Beaufortia 9: 232-240. http://www.repository.naturalis.nl/document/548402.

Kingsolver, J.M., 1969. A new species of Neotropical seed weevil affecting pigeon peas, with notes on two closely related species (Coleoptera: Bruchidae: Bruchinae). - Proceedings of the Entomological Society of Washington 71: 50-55. https://www.biodiversitylibrary.org/ page/ 16277550 .

Kingsolver, J.M., 1970. A synopsis of the subfamily Amblycerinae Bridwell in the West Indies, with descriptions of new species (Coleoptera: Bruchidae). - Transactions of the American Entomological Society 96: 469-497. https://www.jstor.org/stable/25078001.

Kingsolver, J.M., 1972. Synopsis of the genus Stator Bridwell in the West Indies, with descriptions of new species (Coleoptera: Bruchidae). - Proceedings of the Entomological Society of Washington 74: 219-229. https://www.biodiversitylibrary.org/page/ 16246 402.

Kingsolver, J.M. \& C.D. Johnson, 1978. Systematics of the genus Mimosestes (Coleoptera: Bruchidae). United States Department of Agriculture Technical Bulletin 1590: 1-106. https://ageconsearch.umn.edu/ record/157736/files/tb1590.pdf.

Kingsolver, J.M., J.E. Barriga Tuñón, J.R. Nápoles \& M.C. Thomas, 2017. Bruchidae of Chile (Insecta: Coleoptera). - Insecta Mundi 542: 1-106. https://journals .flvc.org/mundi/article/view/0542.

Kirby, W., 1826. Cryptophagidae. - In: W. Kirby \& W. Spence. An introduction to entomology: or elements of the natural history of insects: with plates. Vol. IV: p. 504. Longman, Rees, Orme, Brown and Green, London, UK. https:/www.biodiversitylibrary.org/ page/24766131.

Kirby, W., 1837. Silvanidae. - In: Richardson, J. (Ed.), Fauna Boreali-Americana or the zoology of the northern parts of British America. Part the fourth and last. Insecta: p. 110-111. Josiah Fletcher, London, UK. https://www.biodiversitylibrary.org/page/41550147.
Kirejtshuk, A.G., 1996. Some results of study on the Nitidulidae from Namibia and adjacent territories. Part 1. (Coleoptera, Cucujoidea, Nitidulidae). - Mitteilungen aus dem Museum für Naturkunde in Berlin, Zoologische Reihe 72: 21-52. doi: 10.1002/ mmnz.19960720106.

Kirejtshuk, A.G. \& P. Audisio, 1986. Cillaeinae. Coleopterists Bulletin 40: 219. https://www.jstor.org/ stable/4008349.

Kirsch, T., 1866. Beiträge zur Käferfauna von Bogotà (Zweites Stück). -Berliner Entomologische Zeitschrift 10: 173-216. https://www.biodiversitylibrary.org/ page/8340301.

Kirsch, T., 1873. Beiträge zur Kenntnis der Peruanischen Käferfauna auf Dr. Abendroth's Sammlungen basirt. Berliner Entomologische Zeitschrift 17 (1-2): 121-152. https://www.biodiversitylibrary.org/page/8341199.

Kissinger, D.G., 1974. Apioninae occurring in the West Indies (Curculionidae, Coleoptera). - Taxonomic Publications, Riverside, California, USA, $57 \mathrm{pp}$.

Kleefstra, N., 2019. Record with photo on the citizen science website Observation.org. - https://observation .org/waarneming/view/176946597.

Klug, J.F.C., 1833. Bericht über eine auf Madagascar veranstaltete Sammlung von Insecten aus der Ordnung Coleoptera. - Königlichen Akademie der Wissenschaften, Berlin, 135 pp. +5 pls.

Klug, J.F.C., 1834a. Uebersicht der Cicindeletae der Sammlung. - Jahrbücher der Insectenkunde 1: 1-47. https://www.biodiversitylibrary.org/page/12253452.

Klug, J.F.C., 1834b [1832]. Bericht über eine auf Madagascar veranstaltete Sammlung von Insecten aus der Ordnung Coleoptera Abhandlungen der Königlichen. Akademie der Wissenschaften zu Berlin 1832: 91-223. https://www.biodiversitylibrary.org/page/29725718.

Krafsur, E.S \& J.J. Obrycki, 2000. Coleomegilla maculata (Coleoptera: Coccinellidae) is a species complex. - Annals of the Entomological Society of America 93: 11561163.doi: 10.1603/0013-8746(2000)093[1156:CMCCIA]2.0.CO;2.

Kruithof, A., 2016. Record with photo on the citizen science website Observation.org. - https://observation. org/waarneming/view/133041346.

Kruithof, A., 2018. Two records with photo on the citizen science website Observation.org. - https://observation .org/waarneming/view/163067979, https://observa tion.org/waarneming/view/163898808.

Kuijten, P.J., 1983. Revision of the genus Hybosorus MacLeay (Coleoptera: Scarabaeidae, Hybosorinae). Zoologische Verhandelingen 203: 3-49. http://www .repository.naturalis.nl/document/148983.

Kuschel, G. 1961. On problems of synonymy in the Sitophilus oryzae complex (30th contribution, Col. Curculionoidea). - Annals and Magazine of Natural History Ser. 13, 4: 241-244. doi: 10.1080/ 00222936108651102.

Lacordaire, T., 1859. Histoire naturelle des insectes. Genera des Coléoptères ou exposé méthodique et critique de tous les genres proposés jusqu'ici dans cet ordre d'insectes. Tome cinquième contenant les familles

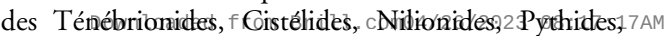
via free access 
Mélandryides, Lagriides, Pédilides, Anthicides, Pyrochroïdes, Mordellides, Rhipiphorides, Stylopides, Meloïdes et Oedémérides. - Librairie Encyclopédique de Roret, Paris, France, 750 pp. https:/www.biodiver sitylibrary.org/page/9615257.

Lacordaire, T., 1865. Histoire naturelle des insectes. Genera des Coléoptères ou exposé méthodique et critique de tous les genres proposés jusqu'ici dans cet ordre d'insectes. Tome septième contenant les familles des Curculionides (suite), Scolytides, Brenthides, Anthribides et Bruchides. - Librairie Encyclopédique de Roret, Paris, France, [2] + 620 pp. https://www.biodiver sitylibrary.org/page/42574533.

Lalanne-Cassou, B., 2020 ResearchGate profile. - available at https://www.researchgate.net/profile/Bernard _Lalanne-Cassou.

Lameere, A.A.L., 1902. Révision des Prionides. Quatrième mémoire - Sténodontines. - Mémoires de la Société Entomologique de Belgique 9: 63-110.

Laporte, F.L.N. de, 1835. Études entomologiques, ou description d'insectes nouveaux, et observations sur leur synonymie. Première partie, - Méquignon-Marvis, Paris, France. https://books.google.nl/books?id=Ws9C AQAAMAAJ\&printsec $=$ frontcover $\& h \mathrm{hl}=\mathrm{nl} \&$ source $=$ gbs_ViewAPI\&redir_esc $=y \# v=$ onepage $\& \mathrm{q} \& \mathrm{f}=$ false.

Laporte, F.L.N. de, 1836. Études entomologiques, ou description d'insectes nouveaux et observations sur leur synonymie. - Revue Entomologique 4: 5-60. https:// www.biodiversitylibrary.org/page/25528861.

[Laporte] de Castelnau, [F.L.N.], 1840. Histoire naturelle des insectes coléoptères. Tome deuxième. - P. Duménil, Paris, France, 563 pp. + 38 pls. https://www.biodiver sitylibrary.org/page/25258127.

Laporte, F.L.N. de \& G.A. Brullé, 1831. Monographie du genre Diaperis. - Annales des Sciences Naturelles 23: 325-410. https://www.biodiversitylibrary.org/ page/6013197.

Latreille, P.A., 1796. Précis des caractères génériques des insectes, disposés dans un ordre naturel. - Prévôt, Paris, France, xiii + 201 pp. https://www.biodiversitylibrary .org/page/38812267.

Latreille, P.A., 1802. Histoire naturelle, générale et particulière des crustacés et des insectes. Ouvrage faisant suite à l'histoire naturelle générale et particulière, composée par Leclerc de Buffon, et rédigée par C.S. Sonnini, membre de plusieurs sociétés savantes. Familles naturelles des genres. Tome troisième. - F. Dufart, Paris, France, xii + 13-467. https://www.biodiversitylibrary .org/page/24884921.

Latreille, P.A., 1804. Tableau méthodique des insectes. In: Nouveau dictionnaire d'histoire naturelle, appliquée aux arts, pricipalement à l'agriculture et à l'économie rurale et domestique: par une société de naturalistes et d'agriculteurs Tableaux méthodiques d'histoire naturelle. Tome XXIV: pp. 129-200. Déterville, Paris, France. https://www.biodiversitylibrary.org/page/5778 4732.

Latreille, P.A., 1807. Genera crustaceorum et insectorum secundum ordinem naturalem in familias disposita, iconibus exemplisque plurimis explicata. Tomus tertius.
- Amand König, Paris/Strasbourg, France, 258 pp. https://www.biodiversitylibrary.org/page/11998115.

Latreille, P.A., 1809. Genera crustaceorum et insectorum secundum ordinem naturalem in familias disposita, iconibus exemplisque plurimis explicata. Tomus quartus et ultimus. - Amand Koenig, Paris//Strasbourg, France, 399 pp. https:/www.biodiversitylibrary.org/ page/42113867.

Latreille, P.A., 1810. Considérations générales sur l'ordre naturel des animaux composant les classes des crustacés, des arachnides, et des insectes; avec un tableau méthodique de leurs genres, disposés en familles. - F. Schoell, Paris, France, 444 pp. https:/www.biodiver sitylibrary.org/page/27543876.

Latreille, P.A., 1813. Insectes de l'Amérique équinoxiale recueillis pendant le voyage de $\mathrm{Mm}$. de Humboldt et Bonpland. Seconde partie. [Livraison viii]: pp. 9-64 + pls. 31-34. - In: de Humboldt, A. \& A. Bonpland (Eds), Recueil d'observations de zoologie et d'anatomie comparée faites dans l'océan Atlantique, dans l'intérieur du nouveau continent et dans la mer du sud, pendant les années 1799, 1800, 1801, 1802 et 1803. Smith et Gide, Paris, France. https://www.deutsche-digitale -bibliothek.de/item/WUHYEQCJCSAVN24MMZC MBZMOTPHWO6JC.

Latreille, P.A., 1819. Trachélides. - In: Nouveau dictionnaire d'histoire naturelle, appliquée aux arts, à l'agriculture, à l'économie rurale et domestique, à la médecine, etc. par une société de naturalistes et d'agriculteurs. Nouvelle édition. Tome XXXIV: pp. 362-364. Déterville, Paris, France. https://www.biodi versitylibrary.org/page/19479047.

Latreille, P.A., 1825. Familles naturelles du règne animal, exposées succinctement et dans un ordre analytique, avec l'indication de leurs genres. - J.-B. Baillière, Paris, France, 570 pp. https://www.biodiversitylibrary.org/ page/ 16037964.

Lawrence, J.F., 1971. Revision of the North American Ciidae (Coleoptera). - Bulletin of the Museum of Comparative Zoology 142: 419-522. https://www.biodiver sitylibrary.org/page/4775898.

Lawrence, J.F. \& A.F. Newton, 1995. Families and subfamilies of Coleoptera (with selected genera, notes, references and data on family-group names). - In: J. Pakaluk \& S.A. Ślipiński (Eds), Biology, phylogeny and classification of Coleoptera: Papers celebrating the 80th birthday of Roy A. Crowson, Vol. II: pp. 779-1006. Muzeum i Instytut Zoologii PAN, Warsaw, Poland.

Leach, W.E., 1815. Entomology. - In: D. Brewster (Ed.), Brewster's Edinburgh Encyclopaedia., Vol. IX [part I]: pp. 57-172. W. Blackwood, J. Waugh, Edinburgh, etc., UK. [1830 edition seen]. https://www.biodiver sitylibrary.org/page/17493547.

Leach, W.E., 1817. The zoological miscellany; being descriptions of new, or interesting animals. Vol. III. - E. Nodder \& Son, London, UK, v + 151 + pls. 121-150. https://www.biodiversitylibrary.org/page/28686804.

Leach, W.E., 1819a. Melolonthidae. - In: G. Samouelle, The Entomologist's useful compendium; or an introduction to the knowledge of British insects, comprising Downloaded from Brill.com04/26/2023 08:17:17AM via free access 
the best means of obtaining and preserving them, and a description of the apparatus generally used; together with the genera of Linné, and the modern method of arranging the classes Crustacea, Myriapoda, spiders, mites, and insects from their affinities and structure, according to the views of Dr. Leach. Also an explanation of the terms used in entomology; a calendar of the times of appearance, and usual situations of near 3,000 species of British insects; with instructions for collecting and fitting up objects for the microscope: pp. 189-190. Thomas Boys, London, UK. https://www.biodiversitylibrary.org/page/24539 313.

Leach, W.E., 1819b. Cisidae. - In: G. Samouelle, The Entomologist's useful compendium; or an introduction to the knowledge of British insects, comprising the best means of obtaining and preserving them, and a description of the apparatus generally used; together with the genera of Linné, and the modern method of arranging the classes Crustacea, Myriapoda, spiders, mites, and insects from their affinities and structure, according to the views of Dr. Leach. Also an explanation of the terms used in entomology; a calendar of the times of appearance, and usual situations of near 3,000 species of British insects; with instructions for collecting and fitting up objects for the microscope: p. 206. Thomas Boys, London, UK. https://www.biodiversitylibrary .org/page/24539330.

LeConte, J.L., 1852a. Remarks upon the Coccinellidae of the United States. - Proceedings of the Academy of Natural Sciences of Philadelphia 6: 129-145. https:// www.biodiversitylibrary.org/page/1779665.

LeConte, J.L., 1852b. An attempt to classify the longicorn Coleoptera of the part of America North of Mexico. Part III. Containing the Lamiae. - Journal of the Academy of Natural Sciences of Philadelphia, Ser. 2, 2: 139-178. https://www.biodiversitylibrary.org/ page/35731042.

LeConte, J.L., 1853a. Notes on the Classification of the Carabidae of the United States. - Transactions of the American Philosophical Society 10: 363-403. https:// www.jstor.org/stable/1005287.

LeConte, J.L., 1853b. Synopsis of the species of the histeroid genus Abraeus (Leach.) inhabiting the United States, with descriptions of two nearly allied new genera. - Proceedings of the Academy of Natural Sciences of Philadelphia 6: 287-292. https://www.biodiversity library.org/page/1779823.

LeConte, J.L., 1861. Classification of the Coleoptera of North America. Part I. - Smithsonian Miscellaneous Collections 3 (136): 1-208. https://www.biodiversity library.org/page/26620891.

LeConte, J.L., 1876. The Rhynchophora of America North of Mexico. - Proceedings of the American Philosophical Society 15: 1-455. https://www.biodiversitylibrary .org/page/17073741.

LeConte, J.L., 1878. Additional descriptions of new species. - Proceedings of the American Philosophical Society 17 : 373-434. https://www.biodiversitylibrary.org/ page/29847962.
Lemaire, J.-M., 2017. Les Carabiques des Antilles françaises: captures récentes et données nouvelles (Coleoptera, Carabidae). - Contribution à l'étude des Coléoptères des Petites Antilles (supplément a Le Coléoptériste) 3: 55-63.

Leng, Ch.W., 1920. Catalogue of the Coleoptera of America, North of Mexico. - John D. Sherman Jr., Mount Vernon, NY, USA, $x+470$ pp. https://www.biodiver sitylibrary.org/page/16147312.

Leng, Ch.W. \& A.J. Mutchler, 1914. A preliminary list of the Coleoptera of the West Indies as recorded to Jan. 1, 1914. - Bulletin of the American Museum of Natural History 33: 391-493. http://hdl.handle.net/2246/909.

Leng, Ch.W. \& A.J. Mutchler, 1917. Supplement to preliminary list of the Coleoptera of the West Indies. Bulletin of the American Museum of Natural History 37: 191-220. http://hdl.handle.net/2246/910.

Lepesme, P., 1947. Famille des Anobiidae. - In: E. Fleutiaux, C. Legros, P. Lepesme \& R. Paulian (Eds), Faune de l'Empire Français 7. Coléoptères des Antilles, Vol. 1: pp. 211-228. Office de la Recherche Scientifique Coloniale, Paris, France. https://horizon.documentation .ird.fr/exl-doc/pleins_textes/divers14-12/43692.pdf.

Lesne, P., 1896. Revision des Coléoptères de la famille des Bostrychides. - Annales de la Societé Entomologique de France 65: 95-127. https://www.biodiversityli brary.org/page/8312767.

Lesne, P., 1899. Revision des Coléoptères de la famille des Bostrychides 3e Mémoire (1). Bostrychinae. - Annales de la Societé Entomologique de France 67: 438-621. https://www.biodiversitylibrary.org/page/8313872.

Lesne, P., 1906. Bostrychides nouveaux ou peu connus \$2. Les Heterarthron des Antilles. - Annales de la Societé Entomologique de France 75: 394-399. https://www .biodiversitylibrary.org/page/9207300.

Letzner, K.W., 1849. 2. Bericht über die Arbeiten der entomologischen Sektion im Jahre 1848. 2. Käfer. In: Uebersicht der Arbeiten und Veränderungen der Schlesischen Gesellschaft für vaterländische Kultur im Jahre 1848: pp. 95-99. Graß, Barth und Comp., Breslau. https://www.biodiversitylibrary.org/page/39079 105.

Lewis, G., 1888. Fam. Histeridae. - In: F.D. Godman \& O. Salvin (Eds), Biologia Centrali-Americana Insecta Coleoptera Vol. II. Part 1: pp. 182-244. R.H. Porter, London, UK. https://www.biodiversitylibrary.org/ page/578099.

Lhoste, J., 1987. Les entomologistes français (1750-1950). - Institut National de la Recherche Agronomique, Paris, France, 351 pp.

Lingafelter, S.W., 2011. New records of Caribbomerus from Hispaniola and Dominica with redescription of C. elongatus (Fisher) and a key to species of the genus in the West Indies (Coleoptera, Cerambycidae, Cerambycinae, Graciliini). - ZooKeys 85: 27-39. doi: 10.3897/ zookeys.85.826.

Linnaeus, C., 1758. Systema naturae per regna tria naturae, secundum classes, ordines, genera, species, cum characteribus, differentiis, synonymis, locis. Tomus I. Editio decima, reformata. Laurentii Salvii, Stockholm, 
Sweden, 823 pp. https://www.biodiversitylibrary.org/ page/726886.

Linnaeus, C., 1763. Centuria insectorum rariorum. Uppsala, Sweden, 32 pp. https://www.biodiversityli brary.org/page/10974720.

Linnaeus, C., 1767. Systema naturae per regna tria naturae, secundum classes, ordines, genera, species, cum characteribus, differentiis, synonymis, locis. Editio duodecima, reformata. Tom. I. Pars II: pp. 533-1327. - Laurentii Salvii, Stockholm, Sweden. https://www .biodiversitylibrary.org/page/461997.

Linnaeus, C., 1771. Mantissa plantarum altera generum editionis VI. \& Specierum editionis II: pp. 143-587. - Laurentii Salvii, Stockholm, Sweden,. https://www .biodiversitylibrary.org/page/42945316.

López-García, M.M., H.J. Gasca-Álvarez, R.D. Cave \& G. Amat-García, 2016. An annotated checklist of the New World pentodontine scarab beetles (Coleoptera: Scarabaeidae: Dynastinae: Pentodontini). - Zootaxa 4170: 491-509. doi: 10.11646/zootaxa.4170.3.4.

Louwsma, A., 2018. Record with photo on iNaturalist. https://www.inaturalist.org/observations/19190322.

Low, M.E.Y., P.K.L. Ng \& N.L. Evenhuis, 2013. Names and publication dates of the Brachyura in F.É. Guérin (Guérin-Méneville) (Crustacea: Decapoda) . - Zootaxa 3736: 101-127. doi: 10.11646/zootaxa.3736.2.1.

Löwegren, Y., 1952. Naturaliekabinett i Sverige under 1700-talet. Ett bidrag till zoologiens historia. Lychnos-Bibliotek 13, Almqvist \& Wiksell, Uppsala, Sweden, 407 pp.

Lumen, R., M.J. Kamiński, J. Crowley \& A.D. Smith, 2019. Revision of the genus Ulus Horn, 1870 (Coleoptera: Tenebrionidae: Opatrini: Blapstinina). - Annales Zoologici 69: 827-856. doi: 10.3161/00034541ANZ 2019.69.4.014.

Mac Gillavry, D., 1931. Bibliographische bijdrage II. Entomologische Berichten 8: 173-180. https://www .biodiversitylibrary.org/page/57814377.

Mac Gillavry, H.J., 1934. Iets over insecten van Curaçao. Natuur en Mensch 54: 54-55.

MacLeay, W.S., 1819. Horae Entomologicae: or essays on the annulose animals. Vol. 1, Part 1. Containing general observations on the geography, manners, and natural affinities of the insects which compose the genus Scarabaeus of Linnaeus; to which are added a few incidental remarks on the genera Lucanus and Hister of the same author. With an appendix and plates. $-\mathrm{S}$. Bagster, London, UK, xxx + 160 pp. + 3 pls. https:// www.biodiversitylibrary.org/page/33484492.

Macleay, W.S. 1825. Annulosa Javanica or an attempt to illustrate the natural affinities and analogies of the insects collected in Java by T. Horsfield. - Kingsbury, Parbury and Allen, London, 50 pp. https://www.biodi versitylibrary.org/page/12819790.

Maes, J.-M. \& E. Martinez, 1988. Catalogo de Scolytidae y Platypodidae (Coleoptera) de Nicaragua. Revista Nicaraguense de Entomología 3: 1-43. http:// www.bio-nica.info/RevNicaEntomo/3-Scotytidae .pdf.
Maier, C.A. \& M.A. Ivie, 2013. New species and records of Chrysobothris Eschscholtz (Coleoptera: Buprestidae) from Montserrat, Saba, and Anguilla, with a key to the Chrysobothris thoracica species-group in the West Indies. - Coleopterists Bulletin 67: 81-88. doi: 10. 1649/0010-065X-67.2.81.

Makhan, D., 1997. Twenty-six new Scydmaenidae species from South America (Coleoptera: Scydmaenidae). - Annales Historico-Naturales Musei Nationalis Hungarici 89: 123-136. http://publication.nhmus.hu/pdf/ annHNHM/Annals_HNHM_1997_Vol_89_123 .pdf.

Malumphy, C., S. Reid, R. Down, J. Dunn \& D. Collins, 2018. Field guide to invasive alien plant pests in the Caribbean UK Overseas Territories. - Department of Environment, Food and Rural Affairs / Fera Science Limited, York, UK, 258 pp. https://www.sprep.org/ attachments/VirLib/Global/field-guide-invasive-pests -carribean.pdf.

Mantilleri, A., 2014. Révision et phylogénie du genre Nemocephalus Guérin-Méneville 1827 (Coleoptera: Curculionoidea: Brentidae). - Annales de la Societé Entomologique de France (N.S.) 50: 111-128. doi: 10.1080/00379271.2014.934041.

Marcuzzi, G., 1951. Contributi alia conoscenza dei Tenebrionidi venezuelani. - Atti Museo Civico Storia Naturale Trieste 18: 61-80.

Marcuzzi, G., 1953. Contributi alla conoscenza dei Tenebrionidi sud-americani V. Nuove specie del genere Rhypasma. - Atti Museo Civico Storia Naturale Trieste 19: 73-86.

Marcuzzi, G., 1954. Tenebrionid beetles of Curaçao, Aruba, Bonaire, and the Venezuelan islands. - Studies on the Fauna of Curaçao and other Caribbean Islands 5: 1-36. http://www.repository.naturalis.nl/doc ument $/ 549933$.

Marcuzzi, G., 1957. Considerazioni zoogeografiche sui Tenebrionidi delle Antille. - Estratto dal Monitore Zoologico Italiano 65: 127-141.

Marcuzzi, G., 1959. Tenebrionid beetles of Curaçao, Aruba, Bonaire, and Venezuela. - Studies on the Fauna of Curaçao and other Caribbean Islands 9 (1): 79-91. http://www.repository.naturalis.nl/document/549991.

Marcuzzi, G., 1961a. Revisione delle specie Venezuelane della tribù Epitragini (Col. Tenebr.) con appunti su altre specie neotropicali. - Annali del Museo Civico di Storia Naturale di Genova 72: 313-352.

Marcuzzi, G., 1961b. Descrizione di nuove specie di Tenebrionidi Neotropicali appartenenti alla Tribu Epitragini. -Universita degli Studi di Trieste, Facolta di Scienze, Istituto du Zoologia 2: 1-41.

Marcuzzi, G., 1962. Tenebrionid beetles of the West Indies. - Studies on the Fauna of Curaçao and other Caribbean Islands 13: 21-48. http://www.repository. naturalis.nl/document/549867.

Marcuzzi, G., 1977. Further studies on Caribbean tenebrionid beetles. - Studies on the Fauna of Curaçao and other Caribbean Islands 52: 1-71. https://www.re pository.naturalis.nl/document/549974. 
Marcuzzi, G., 1983. Description of external male genitalia of some Neotropical Tenebrionidae (Col. Heteromera). - Folia Entomologica Hungarica 44: 239-269. http://publication.nhmus.hu/pdf/folentom/FoliaEnt Hung_1983_Vol_44_2_239.pdf.

Marcuzzi, G., 1984. A catalogue of Tenebrionid beetles (Coleoptera: Heteromera) of the West Indies. - Folia Entomologica Hungarica 45 (1): 69-108. http://publi cation.nhmus.hu/pdf/folentom/FoliaEntHung_1984 _Vol_45_1_69.pdf.

Marcuzzi, G., 1987. Description of the external female genitalia of some Neotropical Tenebrionidae (Coleoptera: Heteromera). - Acta Zoologica Hungarica 33: 87-112.

Marcuzzi, G., 2001. One new species and two new subspecies of Tenebrionidae (Coleoptera) of the West Indies, with new distributional data for other species of this family. - Bulletin de la Societé Linnéenne de Bordeaux 29: 249-253. https://www.biodiversitylibrary.org/page/ 50384831.

Marcuzzi, G., 2002. Description of some new Neotropical Tenebrionidae (Coleoptera, Heteromera). - Annali del Museo Civico di Storia Naturale Giacomo Doria 94: 395-406.

Marcuzzi, G. \& J. d'Aguilar, 1971. Catalogue raisonné des insectes des Antilles Françaises 3. Coleopteres: Tenebrionidae. - Annales de Zoologie et d'Ecologie Animale 3: 79-96.

Marseul, S.A. 1855. Essai monographique sur la famille des Histérides. - Annales de la Société Entomologique de France Ser. 3, 3: 327-506. https://www.biodiver sitylibrary.org/page/32541979.

Marseul, S.A. 1870. Descriptions d'espèces nouvelles d'histérides. - Annales de la Société Entomologique de Belgique 13: 55-138. https://www.biodiversitylibrary .org/page/12370247.

Marshall, T.A., 1878. Notes on the entomology of the Windward Islands. - Transactions of the Royal Entomological Society of London 26: xxvii-xxxviii. doi: 10.1111/j.1365-2311.1878.tb01961.x.

Marshall, G.A.K., 1912. Three new species of neotropical Coccinellidae. - Annals and Magazine of Natural History Ser. 8, 10: 320-322. doi: 10.1080/ 00222931208693241.

Marshall, J.A., 1983. The orthopteroid insects described by Linnaeus, with notes on the Linnaean collection. - Zoological Journal of the Linnean Society 78: 375-396. https://doi.org/10.1111/j.1096-3642.1975.tb02266.x.

Marshall, S.A. 2020. ResearchGate profile. - available at https://www.researchgate.net/profile/ Stephen_Marshall9.

Marsham, T., 1802. Entomologia Britannica, sistens insecta Britanniae indigena, secundum methodum Linnaeanam disposita. Tomus I. Coleoptera. - Wilks et Taylor, London, UK, xxxi + 547 pp. https://www.biodiversity library.org/page/42039332.

Martin, K., 1885. De Nederlandsche expeditie naar de West-Indische eilanden en Suriname 1884-1885. I. beschrijving der reis op de W.-I. eilanden door Prof. Dr. K.
Martin. I. Aruba. II. Bonaire. III. Curaçao. - Tijdschrift van het Koninklijk Nederlands Aardrijkskundig Genootschap (2) 2: 337-361; 448-487; 610-646. https:// www.delpher.nl/nl/tijdschriften/view? coll=dts \& identifier=MMUBA13:001599001:00363.

Martin, K., 1888. Bericht über eine Reise nach Niederländisch West Indien und darauf gegründete Studien. Erster Theil. Land und Leute. - Brill, Leiden, The Netherlands, 186 pp. + 22 pls. https://archive.org/details/ berichtbereine $01 \mathrm{mart} / \mathrm{page} / \mathrm{n} 5 /$ mode $/ 2 \mathrm{up}$.

Martins, U.R., 1997. Contribuições para uma revisão das espécies sul-americanas da Tribo Eburiini (Coleoptera, Cerambycidae). - Revista Brasileira de Entomologia 41: 57-83.

Martins, U.R., 2005. Cerambycidae sul-americanos (Coleoptera). Taxonomia, Vol. 7. Subfamília Cerambycinae Elaphidionini, Thomson, 1864. - Sociedade Brasileira de Entomologia, São Paulo, Brazil, 394 pp.

Martis, A., G.J. van Oldenborgh \& G. Burgers, 2002. Predicting rainfall in the Dutch Caribbean-more than El Niño? - International Journal of Climatology 22: 1219-1234. doi: 10.1002/joc.779.

Maskell, W.M., 1878. On some Coccidae in New Zealand, Transactions and proceedings of the New Zealand Institute 11: 187-228. http://rsnz.natlib.govt.nz/vol ume/rsnz_11/rsnz_11_00_001140.pdf.

Mazur, S., 2011. A concise catalogue of the Histeridae (Insecta: Coleoptera). - Warshaw University of Life Sciences, SGGW Press, Warszawa, 332 pp.

McCrone, J.D. \& H.W. Levi, 1964. North American widow spiders of the Latrodectus curacaviensis group (Araneae, Theridiidae). - Psyche 71: 12-27. doi: $10.1155 / 1964 / 86469$.

MDNA\&A [2009]. Climatological Report 2008. Meteorological Service of the Netherlands Antilles and Aruba, Seru Mahuma, Willemstad, Curaçao, $37 \mathrm{pp}$.

MDNA\&A 2010. Hurricanes and tropical storms in the Netherlands Antilles and Aruba. - Meteorological Service of the Netherlands Antilles and Aruba, Seru Mahuma, Willemstad, Curaçao, $38 \mathrm{pp}$.

Mellié, J., 1849 [1848]. Monographie de l'ancien genre Cis des auteurs. - Annales de la Société Entomologique de France Ser. 2, 6: 205-274; 313-396. https://www .biodiversitylibrary.org/page/9485625, https://www .biodiversitylibrary.org/page/9485733.

Melsheimer, F.E., 1845 [1845]. Descriptions of new species of Coleoptera of the United States. - Proceedings of the Academy of Natural Sciences of Philadelphia 2: 134-160. https://www.biodiversitylibrary.org/ page/26280194.

Menke, A.S., 1963. The dates of publication of Palisot de Beauvois' "Insectes recueilles en Afrique et en Amérique". - Annals and Magazine of Natural History Ser. 13, 5: 701-702. doi: 10.1080/00222936208651304.

Meurgey, F., 2017. Nouvelles observations de Protaetia fusca (Herbst, 1790) en Guadeloupe (Antilles françaises) (Coleoptera, Scarabaeidae, Cetoniinae). - Contribution à l'étude des Coléoptères des Petites Antilles (supplément 
a Le Coléoptériste) 3: 3-6. https://www.researchgate .net/publication/320962111_Nouvelles_observa tions_de_Protaetia_fusca_Herbst_1790_en_Guade loupe_Antilles_francaises_Coleoptera_Scarabaeidae _Cetoniinae.

Miller, J.A., M. Stech, T. van Andel, J. Smit, A.J. [de] Winter, E. Colijn, R. Butôt, K. Biesmeijer, H. Madden \& B. van der Hoorn, 2017. A multi-taxon cyberdiversity inventory of a small Caribbean island. - Presented at Entomology2017, November 5-8, 2017, Denver, CO, USA. https://esa.confex.com/esa/2017/meetingapp .cgi/Paper/124262.

Miller, J.A., M. Stech, T. van Andel, J. Smit, A.J. de Winter, E. Colijn, R. Bûtot, K. Biesmeijer, H. Madden \& B. van der Hoorn, 2019. A multi-taxon cyberdiversity inventory of a small Caribbean island. - Abstract book of the XXI International Congress of Arachnology, Canterbury, New Zealand 10-15 February 2019: 6263. https://arachnology.org/fileadmin/user_upload/ ICA/ICA_2019/Abstract_book_FINAL.pdf.

Miskimen, G.W. \& R.M. Bond, 1970. The insect fauna of St. Croix, United States Virgin Islands. - Scientific Survey of Porto Rico and the Virgin Islands (New York Academy of Sciences) 13: 1-114.

Mlodinow, S., 2017. Records with photo on iNaturalist. https://www.inaturalist.org/observations/5877390, https://www.inaturalist.org/observations/5192312, https://www.inaturalist.org/observations/5189114.

Molengraaff, G.J.H., 1929. Geologie en geohydrologie van het eiland Curaçao. - Doctoral thesis, Technische Hoogeschool, Delft, The Netherlands, vii-xii + 126 pp. + 28 pls. https://repository.tudelft.nl/island ora/object/uuid:b2cd9ac9-6054-4f46-a765-d8c $583 \mathrm{~b} 70 \mathrm{~b} 10$ ? collection=research.

Monné, M.A., 2020a. Catalogue of the Cerambycidae (Coleoptera) of the Neotropical Region. Part I. Subfamily Cerambycinae. - Digital publication available at https://cerambycids.com/catalog/Monne_2020_Neo tropicalCat_part_I.pdf.

Monné, M.A., 2020b. Catalogue of the Cerambycidae (Coleoptera) of the Neotropical Region. Part II. Subfamily Lamiinae. - Digital publication available at https://cerambycids.com/catalog/ Monne_2020_NeotropicalCat_part_II.pdf.

Monné, M.L. \& M.A. Monné, 2006. Notes on Acanthoderini (Coleoptera, Cerambycidae, Lamiinae) described by Ernst Fuchs, now in the Herbert Schmid Collection, Vienna, Austria. - Zootaxa 1365: 37-47. doi: 10.11646/zootaxa.1365.1.3.

Montrouzier, [X.] 1861. Essai sur la faune entomologique de la Nouvelle-Calédonie (balade) et des îles des Pins, Art, Lifu, etc.. - Annales de la Société Entomologique de France Ser. 4, 1: 265-306. https://www.biodiver sitylibrary.org/page/8256387.

Moore, T. \& T. Lander, 2010. Révision du genre Conognatha. - Editions Magellanes, Collection Systématique. 24: 1-171.

Moore, M.R., R.D. Cave \& M.A. Branham, 2018. Annotated catalog and bibliography of the cyclocephaline scarab beetles (Coleoptera, Scarabaeidae, Dynastinae, Cyclocephalini). - ZooKeys 745: 101-378. doi: 10.3897/zookeys.745.23685.

Moore, M.R., S.M. Harrison, R.D. Cave \& M.A. Branham, 2020. Mitochondrial sequence data clarify species concepts in the Cyclocephala mafaffa species complex (Coleoptera: Scarabaeidae: Dynastinae: Cyclocephalini). - Zootaxa 4772: 89-110. doi: 10.11646/ zootaxa.4772.1.3.

Motschulsky, V., 1855. Notices. - Études Entomologiques 4: 77-78. https:/www.biodiversitylibrary.org/page/ 51901407.

Motschulsky, V., 1858. Insectes des Indes orientales. 1:ière Série. - Etudes Entomologiques 7: 20-122. https:// www.biodiversitylibrary.org/page/51901448.

Motschulsky, V., 1866. Essai d'un catalogue des insectes de l'ile de Ceylon. Supplément. - Bulletin de la Société impériale des Naturalistes de Moscou 39 (2): 393-446. https://www.biodiversitylibrary.org/page/44324546.

Mulsant, E., 1846. Histoire naturelle des coléoptères de France - Sulcicolles et Sécuripalpes. - L. Maison, Paris, France, xxiv $+25+280$ pp. https://archive.org/stream/ histoirenaturel04mulsgoog\#page/n6/mode/2up.

Mulsant, E., 1850. Species des coléoptères trimères sécuripalpes. - Annales des Sciences Physiques et Naturelles, d'Agriculture et d'Industrie Ser. 2, 2: 1-1104. https:// www.biodiversitylibrary.org/page/3489527.

Mulsant, E., 1853. Supplément à la Monographie des Coccinellides. - Opuscules Entomologiques 3: 9-170. https://www.biodiversitylibrary.org/page/2658765.

Mulsant, E., 1856. Histoire naturelle des coléoptères de France - Longipèdes. - L. Maison, Paris, France, 171 pp. +1 pl. https://reader.digitale-sammlungen.de/de/fs1/ object/display/bsb10308287_00003.html.

Mulsant, E. \& C. Rey, 1859. Essai d'une division des derniers Mélasomes. - Opuscules Entomologiques 9: 65-137. https://www.biodiversitylibrary.org/page/ 36417821 .

Murray, A., 1864. Monograph of the family Nitidulariae. - Transactions of the Linnean Society of London 24: 211-414. doi: 10.1111/j.1096-3642.1863 .tb00163.x.

Myers, J.G., 1931. A preliminary report on an investigations into the biological control of West Indian insect pests. - Publications of the Empire Marketing Board 42: 1-172. https://dspace.gipe.ac.in/xmlui/ bitstream/handle/10973/35930/GIPE-017375-10 .pdf?sequence $=3$.

Nabozhenko, M., A. Kirejtshuk, O. Merkl, C. Varela, R. Aalbu \& A. Smith, 2016. Caribanosis gen. nov. from Hispaniola (Pimeliinae: Stenosiini) with taxonomic notes on the tribes Belopini and Stenosini (Coleoptera: Tenebrionidae). - Annales Zoologici 66: 567-570. doi: 10.3161/00034541ANZ2016.66.4.009.

Natural History Museum of Denmark, 2020. The digitized type collection: Sphaeridium testaceum. - Digital publication available at http://daim.snm.ku.dk/digitized -type-collection-details-simple? catno=zmuc00518 712. 
Naturalis, 2018a. Dutch Caribbean Species Register. Phileurus valgus. - Digital publication available at https://www.dutchcaribbeanspecies.org/linnaeus_ng/ app/views/species/nsr_taxon.php?id=187542\#.

Naturalis, 2018b. Dutch Caribbean Species Register. Cheilomenes sexmaculata. - Digital publication available at https://www.dutchcaribbeanspecies.org/linnaeus_ng/ app/views/species/nsr_taxon.php?id=192472\#.

Navarrete-Heredia, J.L., A.F. Newton, M.K. Thayer, J.S. Ashe \& D.S. Chandler, 2002. Guía illustrada para los géneros de Staphylinidae (Coleoptera) de México. - Universidad de Guadelajara, Mexico, 401 pp. http://cezug.org.mx/czug/Documentos_files/ Navarrete,Newton, Thayer+2002_Guia-illustrada -para-los-generos-de-Staphylinidae-de-Mexico _R9209.pdf.

Naviaux, R., 2007. Tetracha (Coleoptera, Cicindelidae, Megacephalina): Révision du genre et descriptions de nouveaux taxons. - Mémoires de la Société Entomologique de France 7: 1-197.

Neervoort van de Poll, J.R.H., 1886. Les Cicindélides de l'ile de Curaçao, avec description d'une Tetracha nouvelle. - Notes from the Leyden Museum 8: 225-227. http://www.repository.naturalis.nl/document/551455.

Newman, E., 1840. Entomological notes. - The Entomologist 1: 27. https://www.biodiversitylibrary.org/ page/11933767.

Newman, E., 1841. Entomological notes. - The Entomologist 1: 110-112. https://www.biodiversitylibrary.org/ page/ 11933850 .

NHRS, 2001. Coleoptera in the Swedish Museum of Natural History, Stockholm. - Digital publication available at http://www2.nrm.se/en/col_preface.html.

Nichols, S.W., 1988. Kaleidoscopic biogeography of West Indian Scaritinae (Coleoptera: Carabidae). - In: J.K. Liebherr (Ed.), Zoogeography of Caribbean insects: pp. 71-120. Cornell University Press, Ithaca, NY, USA.

Nicolas, V., 2012. Étude préliminaire des Coccinelles (Coleoptera, Coccinellidae) des Petites Antilles: Chilocorini et Coccinellini. - Harmonia 9: 10-20. https://www .researchgate.net/publication/328853588_Etude_pre liminaire_des_Coccinelles_Coleoptera_Coccinelli dae_des_Petites_Antilles_Chilocorini_et_Coccinellini.

Nilsson, A.N., 2001. A world catalogue of the family Dytiscidae, or the diving beetles (Coleoptera, Adephaga). - World Catalogue of Insects 3: 1-395.

Nilsson, A.N. \& J. Hájek, 2018. A world catalogue of the family Dytiscidae (Coleoptera, Adephaga). Version 1.I.2018. - Digital publication available at http:// www.waterbeetles.eu/documents/W_CAT_Dytisci dae_2018.pdf.

Nolan, E.J., 1913. Dates of publication. - In: E.J. Nolan (Ed.), An index to the scientific contents of the Journal and Proceedings of the Academy of Natural Sciences of Philadelphia: pp. vii-xiv. The Academy of Natural Sciences, Philadelphia, PA, USA. https://www.biodi versitylibrary.org/page/26311228.

O’Brien, C.W. \& G.J. Wibmer, 1982. Annotated checklist of the weevils (Curculionidae sensu lato) of North
America, Central America, and the West Indies (Coleoptera: Curculionoidea). - Memoirs of the American Entomological Institute 34: 1-382. http://academic .uprm.edu/ franz/WeevilCourseResources/OBrien Wibmer1982-WeevilsNCAWI.pdf.

O’Brien, C.W. \& G.J. Wibmer, 1984. Annotated checklist of the weevils (Curculionidae sensu lato) of North America, Central America, and the West Indies (Coleoptera: Curculionoidea) 1. Supplement 1. - The Southwestern Entomologist 9: 286-307.

O’Brien, C.W., M. Haseeb \& M.C. Thomas, 2006. Myllocerus undecimpustulatus undatus Marshall (Coleoptera: Curculionidae), a recently discovered pest weevil from the Indian Subcontinent. - Florida Department of Agriculture \& Consumer Services, Division of Plant Industry, Entomology Circular 412: 1-4. https://www .fdacs.gov/content/download/36460/file/ento412.pdf.

Obenberger, J., 1924. Kritische Studien über die Buprestiden (Col.). - Archiv für Naturgeschichte (A) 90 (3): 1-171. https://www.zobodat.at/pdf/Archiv -Naturgeschichte_90A_3_0001-0171.pdf.

Ocampo, F.C., 2002. Hybosorids of the United States and expanding distribution of the introduced species Hybosorus illigeri (Coleoptera: Scarabaeoidea: Hybosoridae). - Annals of the Entomological Society of America 95: 316-322. doi: 10.1603/0013-8746(2002)095[0316:HOTUSA]2.0. $\mathrm{CO} ; 2$.

Ochs, G., 1963. Unerwartetes Vorkommen von Taumelkäfern (Gyrinidae) auf Curaçao. - Studies on the Fauna of Curaçao and other Caribbean Islands 14: 123-125. https://www.repository.naturalis.nl/ document/549972.

Oduber, M. 2019. Records with photo on iNaturalist. https://www.inaturalist.org/observations/35463777, https://www.inaturalist.org/observations/31024 944.

Olivier, G.A., 1789a. Entomologie, ou histoire naturelle des insectes, avec leurs caractères génériques et spécifiques, leur description, leur synonymie, et leur figure enluminée. Coléoptères. Tome premier. No. 3. Scarabé Scarabaeus. - Baudouin, Paris, France, 190 pp. https:// www.biodiversitylibrary.org/page/40632461.

Olivier, G.A., 1789b. Entomologie, ou histoire naturelle des insectes, avec leurs caractères génériques et spécifiques, leur description, leur synonymie, et leur figure enluminée. Coléoptères. Tome premier. No. 5. Hanneton Melolontha. - Baudouin, Paris, France, 84 pp. https:// www.biodiversitylibrary.org/page/40632703.

Olivier, G.A., 1790. Encyclopédie méthodique, ou par ordre de matières. Histoire naturelle. Insectes. Tome cinquième. [livraison 41]: pp. 1-368. - Panckoucke, Paris, France. https://www.biodiversitylibrary.org/page/ 24378457.

Olivier, G.A., 1791a. Encyclopédie méthodique, ou par ordre de matières. Histoire naturelle. Insectes. Tome sixième. [livraison 47]: pp. 1-368. - Panckoucke, Paris, France. https://www.biodiversitylibrary.org/page/ 7604689 . 
Olivier, G.A., 1791b. Encyclopédie méthodique, ou par ordre de matières. Histoire naturelle. Insectes. Tome cinquième. [livraison 44]: pp. 369-793. - Panckoucke, Paris, France. https://www.biodiversitylibrary.org/page/ 7577322.

Olivier, G.A. 1792. Encyclopédie méthodique, ou par ordre de matières. Histoire naturelle. Insectes. Tome sixième [livraison 48]: pp. 369-704. - Panckoucke, Paris, France. https://www.biodiversitylibrary.org/page/ 44666797.

Olivier, G.A., 1795. Entomologie, ou histoire naturelle des insectes, avec leurs caractères génériques et spécifiques, leur description, leur synonymie, et leur figure enluminée. Coléoptères. Tome troisième. No. 40. Dytique, Dytiscus. - Lanneau, Paris, France, 39 pp. https://www .biodiversitylibrary.org/page/33603249.

Olivier, G.A., 1800a. Entomologie, ou histoire naturelle des insectes, avec leurs caractères génériques et spécifiques, leur description, leur synonymie, et leur figure enluminée. Coléoptères Tome quatrième, No. 70. Callidie, Callidium. - Lanneau, Paris, France, 72 pp. https://www.biodiversitylibrary.org/page/33799411.

Olivier G.A., 1800b. Entomologie, ou histoire naturelle des insectes, avec leurs caractères génériques et spécifiques, leur description, leur synonymie, et leur figure enluminée. Coléoptères Tome quatrième, No. 68. Saperde, Saperda. - Lanneau, Paris, France, 41 pp. https://www .biodiversitylibrary.org/page/33799339.

Olivier, G.A., 1807. Entomologie, ou histoire naturelle des insectes, avec leurs caractères génériques et spécifiques, leur description, leur synonymie, et leur figure enluminée. Coléoptères Tome cinquième, No. 83. Charanson, Curculio. - Lanneau, Paris, France, pp. 67-428. https://www.biodiversitylibrary.org/page/33660799.

Olivier, G.A., 1808a. Entomologie, ou histoire naturelle des insectes, avec leurs caractères génériques et spécifiques, leur description, leur synonymie, et leur figure enluminée. Coléoptères Tome sixième, No. 97. Casside, Cassida. - Desray, Paris, France, pp. 922-984. https://www.biodiversitylibrary.org/page/33661672.

Olivier, G.A., 1808b. Entomologie, ou histoire naturelle des insectes, avec leurs caractères génériques et spécifiques, leur description, leur synonymie, et leur figure enluminée. Coléoptères Tome sixième, No. 98. Coccinelle, Coccinella. - Desray, Paris, France, pp. 985-1061. https://www.biodiversitylibrary.org/page/33661735.

Opitz, W., 2018. Classification, natural history, and evolution of the subfamily Peloniinae Opitz (Coleoptera: Cleroidea: Cleridae). Part X. Taxonomic rebision of the New World genus Pelonium Spinola. - Entomofauna 39: 337-528. https://www.zobodat.at/pdf/ENT _0039_0337-0528.pdf.

Opitz, W., 2019. Descriptions of new genera and new species of Western Hemisphere checkered beetles (Coleoptera, Cleroidea, Cleridae). - Linzer Biologische Beiträge 51: 959-1076. https://www.zobodat.at/pdf/ LBB_0051_2_0959-1076.pdf.

Orrell, T., 2020. NMNH Extant Specimen Records. Version 1.27. National Museum of Natural History,
Smithsonian Institution. - Occurrence dataset. https:// doi.org/10.15468/hnhrg3 accessed via GBIF.org on 2020-02-03.

Osella, G., 1977. Nuove specie di Curculionidae endogei dell'isola di Cuba (Coleoptera). - Resultats des Expeditions Biospeologiques Cubano-Roumaines à Cuba 2: 397-402.

Osella, G., 1989. Due nuovi curculionidi endogei (Coleoptera) (XXXIV. Contributo alla conoscenza della curculionidofauna endogea). - Revue Suisse de Zoologie 96: 451-458. https:/www.biodiversitylibrary.org/ page/41305050.

Oversteegen, 2019. Record with photo on iNaturalist. https://www.inaturalist.org/observations/36687380.

Palisot de Beauvois, A.M.F.J., 1807. Insectes recueillis en Afrique et en Amérique, dans les Royaumes d'Oware et de Benin, à Saint-Domingue et dans Les États-Unis, pendant les années 1786-1797. [Livraision 5]: pp. 7388, pls. 2, 8 - Levrault, Schoell et Cie, Paris, France.

Palisot de Beauvois, A.M.F.J., 1834. Hypogena tricornis. In: Dejean P.F.M.A., Catalogue des coléoptères de la collection de M. le Comte Dejean. [Deuxième edition. Livraison 3]: pp. 177-256. - Méquignon-Marvis, Paris, France. https://www.e-rara.ch/zut/content/zoom/ 20222921.

Pallas, P.S., 1772. Spicilegia zoologica quibus novae imprimis et obscurae animalium species iconibus, descriptionibus atque commentariis illustrantur. Fasciculus nonus. - Gottl. August. Lange, Berlin, Germany, 86 pp. + 5 pls. https:/www.biodiversitylibrary.org/ page/27823085.

Panzer, G.W.F. 1791. Beschreibung eines noch unbekannten sehr kleinen Kapuzkäfers aus einem westindischen Samen. - Der Naturforscher 25: 35-38. http://ds.ub .uni-bielefeld.de/viewer/image/2108412_025/40/\#top DocAnchor.

Parles, P., 2019. Record with photo on iNaturalist. https://www.inaturalist.org/observations/31933638.

Parsons, C.T., 1943. A revision of Nearctic Nitidulidae (Coleoptera). - Bulletin of the Museum of Comparative Zoology 92: 119-278. https://www.biodiversityli brary.org/page/2825382.

Pascoe, F.P., 1863. List of the Colydiidae collected in the Indian Islands by Alfred R. Wallace, Esq., and descriptions of new species. - Journal of Entomology 2: 121-143. https:/www.biodiversitylibrary.org/ page/ 13387723.

Paulian, R., 1947. Scarabaeoidea.- In: E. Fleutiaux, C. Legros, P. Lepesme \& R. Paulian (Eds.), Faune de l'Empire Français, Vol. 7, Coléoptères des Antilles, pp. 17-84. Office de la Recherche Scientifique Coloniale, Paris, France. https://horizon.documenta tion.ird.fr/exl-doc/pleins_textes/divers14-12/43692 .pdf.

Paulian, R., 1950. Les Corylophidae d'Afrique (Coleoptera). - Mémoires de l'Institut Francais d'Afrique Noire 12: $1-126$.

Paykull, G., 1811. Monographia histeroidum. Stenhammar \& Palmblad, Uppsala, Sweden, 112 pp. + 
13 pls. https://books.google.nl/books?id=ZTZXAAAA $\mathrm{cAAJ} \&$ printsec=frontcover $\# \mathrm{v}=$ onepage.

Pecci-Maddalena, I.S.C. \& C. Lopes-Andrade, 2017. Systematics of the Ceracis furcifer species-group (Coleoptera: Ciidae): the specialized consumers of the bloodred bracket fungus Pycnoporus sanguineus. - Insects 8: 70. doi: 10.3390 /insects 8030070 .

Peck, S.B., 2005. A checklist of the beetles of Cuba with data on distributions and bionomics (Insecta: Coleoptera). - Arthropods of Florida and Neighboring Land Areas 18: 1-241. https://www.fdacs.gov/ezs3down load/download/25123/516039/arthropods-of-florida -vol-18.pdf.

Peck, S.B., 2006. The beetle fauna of Dominica, Lesser Antilles (Insecta: Coleoptera): Diversity and distribution. - Insecta Mundi 20: 165-209. https://journals .flvc.org/mundi/article/view/25087/24418.

Peck, S.B., 2009a. The beetles of Barbados, West Indies (Insecta: Coleoptera): diversity, distribution and faunal structure. - Insecta Mundi 73: 1-51. https://journals .flvc.org/mundi/article/view/0073/24496.

Peck, S.B., 2009b. Beetle species diversity in the Lesser Antilles islands: How many species are really there? Insecta Mundi 78: 1-5. https://journals.flvc.org/mun di/article/view/0078/24501.

Peck, S.B., 2010. The beetles of the island of St. Vincent, Lesser Antilles (Insecta: Coleoptera): diversity and distribution. - Insecta Mundi 144: 1-77. https://journals .flvc.org/mundi/article/view/0144/24567.

Peck, S.B., 2011. The diversity and distributions of the beetles (Insecta: Coleoptera) of the northern Leeward Islands, Lesser Antilles (Anguilla, Antigua, Barbuda, Nevis, Saba, St. Barthélemy, St. Eustatius, St. Kitts, and St. Martin-St. Maarten). - Insecta Mundi 159: 1-54. https://journals.flvc.org/mundi/article/view/0159/ 73892.

Peck, S.B., 2016. The beetles of the Lesser Antilles (Insecta, Coleoptera): diversity and distributions. - Insecta Mundi 460: 1-360. https://journals.flvc.org/mundi/ article/view/0460/103003.

Peck, S.B. \& J. Cook, 2014. A review of the small carrion beetles and the round fungus beetles of the West Indies (Coleoptera: Leiodidae), with descriptions of two new genera and 61 new species. - Insecta Mundi 397: 1-76. https://journals.flvc.org/mundi/article/view/ 0397/80508.

Peck, S.B., M.C. Thomas \& R.H. Turnbow Jr., 2014. The diversity and distributions of the beetles (Insecta: Coleoptera) of the Guadeloupe Archipelago (Grande-Terre, Basse-Terre, La Désirade, Marie-Galante, Les Saintes, and Petite-Terre), Lesser Antilles. - Insecta Mundi 352: 1-156. https://journals.flvc.org/mundi/article/view/ 0352/79879.

Pérez, O.G. \& M.A. Hoy, 2002. Reproductive incompatibility between two subspecies of Coleomegilla maculata (Coleoptera: Coccinellidae). Florida Entomologist 85: 203-207. doi: 10.1653/ $0015-4040(2002) 085$ [0203:RIB T SO] 2.0 $\mathrm{CO} ; 2$
Perty, M., 1830. Delectus animalium articulatorum, quae in itinere per Brasiliam annis MDCCCXVIIMDCCCXX jussu et auspiciis Maximiliani Josephi I. Bavariae regis augustissimi peracto collegerunt Dr. J. B. de Spix et Dr. C. F. Ph. de Martius. - Monachii, 224 pp. +40 pls. https://www.biodiversitylibrary.org/ page/57932815.

Philips, T.K., 1990. The Methiini of the West Indies with notes on circum-Caribbean Methia (Coleoptera: Cerambycidae). - MSc Thesis, Montana State University, $x+137$ pp. http://citeseerx.ist.psu.edu/viewdoc/ download?doi=10.1.1.1002.1917\&rep=rep1\&type= pdf.

Philips, T.K., 2000. Phylogenetic analysis of the New World Ptininae (Coleoptera: Bostrichoidea). - Systematic Entomology 25: 235-262. doi: 10.1046/j.1365-3113.2000.00102.x.

Philips, T.K. \& M.A. Ivie, 1989. Familial placement of Atenizoides curacaoae (Coleoptera: Cerambycidae, Anthicidae). - Pan-Pacific Entomologist 65: 162. https:// www.biodiversitylibrary.org/page/56180282.

Philips, T.K. \& M.A. Ivie, 1998. The Methiini of the West Indies (Coleoptera: Cerambycidae) with notes on the circum-Caribbean species. - Entomologica Scandinavica 29: 57-87. doi: 10.1163/187631298X00203.

Pic, M., 1906. Deux nouveaux Ptinidae de la Guadeloupe. - L’Échange, Revue Linnéenne 22: 21-22.

Pic, M., 1930. Nouveautés diverses. - Mélanges ExoticoEntomologiques 55: 1-36. https://brittlebooks.library .illinois.edu/brittlebooks_open/Books2011-09/pic mau0001 melexo/picmau0001 melexov00000i00055/ picmau0001melexov00000i00055.pdf.

Prena, J., 2008. A synopsis of the orchid weevil genus Orchidophilus Buchanan (Curculionidae, Baridinae), with taxonomic rectifications and description of one new species. - Zootaxa 1783: 18-30. doi: 10.11646/ zootaxa.1783.1.2.

Prena, J., 2009. A review of the species of Geraeus Pascoe and Linogeraeus Casey found in the continental United States (Coleoptera: Curculionidae: Baridinae). - Coleopterists Bulletin 63: 123-172. doi: 10.1649/0010-065X-63.2.123.

Puthz, V., 2012. Über die neuweltlichen MegalopinusArten (Coleoptera: Staphylinidae) (24. Beitrag zur Kenntnis der Megalopsidiinen). - Linzer Biologischer Beiträge 44: 613-834. https://www.zobodat.at/pdf/ LBB_0044_1_0613-0834.pdf.

Putzeys, J., 1846a. Monographie des Clivina et genres voisin. - H. Dessain, Liége, Belgium, 145 pp. https:// www.biodiversitylibrary.org/page/4612723.

Putzeys, J.A.A.H., 1846b. Monographie des Clivina et genres voisin, précédée d'un tableau synoptique des genres de la tribu des Scaritides. - Mémoires de la Société Royale des Sciences de Liége 2: 521-663. https:// www.biodiversitylibrary.org/page/16250086.

Putzeys, J., 1874. Notice sur les cicindèles et carabiques recueillis dans l'île d'Antigoa par M. Purves. - Annales de la Société Entomologique de Belgique 17: 117-119. https://www.biodiversitylibrary.org/page/12727963. 
Putzeys, J., 1878. G. Gynandropus (Dej. spec. V. 817). Entomologische Zeitung 39: 289-295. https://www .biodiversitylibrary.org/page/8988487.

Quensel, C., 1806. Hister laevigatus. - In: C.J. Schönherr, Synonymia insectorum, oder: Versuch einer Synonymie aller bisher bekannten Insecten; nach Fabricii Systema Eleutheratorum geordnet. Mit Berichtigungen und Anmerkungen, wie auch Beschreibungen neuer Arten und illuminirten Kupfern. Erster Band. Eleutherata oder Käfer. Erster Theil. Lethrus... Scolytes: pp. 90-91. Heinr. A. Nordström, Stockholm, Sweden. https://www.biodiversitylibrary.org/page/42218651.

Questel, K., 2014. La liste de la faune de Saint-Barthélemy. Version Août 2014. - Agence Territoriale de l'Environnement de Saint-Barthélemy, 151 pp. + refs.

Questel, K., 2018. La liste de la faune de Saint-Barthélemy. Mise à jour: Juillet 2018. - Bulletin de l'l'Agence Territoriale de l'Environnement de Saint-Barthélemy 3: 1-38. https://agencedelenvironnement.fr/wp-content/ uploads/2018/08/BulletinATEAout2018.pdf.

Questel, K. \& F. Le Quellec, 2012. La faune terrestre et aquatique de Saint-Barthélemy (Antilles françaises). Synthèse bibliographique et quelques données inédites. Version 1.2. - La Réserve Naturelle de SaintBarthélemy, Alsophis et Université des Antilles et de la Guyane, 65 pp. [not seen].

Rafinesque, C.S., 1815. Analyse de la nature ou tableau de l'univers et des corps organisés. - Palermo, Italy, 224 pp. https://www.biodiversitylibrary.org/page/48310197.

Rakovič, M., 1990. Review of the genus Leiopsammodius Rakovič on the world basis with a key to species from the Western Hemisphere and description of a new species (Coleoptera, Scarabaeidae, Aphodiinae). - Annotationes Zoologicae et Botanicae Bratislava 197: 1-18.

Ramakrishna Aiyar, T.V. 1925. An undescribed coccinellid beetle of economic importance. - Journal of the Bombay Natural History Society 30: 491-492. https:// www.biodiversitylibrary.org/page/47561904.

Ratcliffe, B.C., 2003. The dynastine scarab beetles of Costa Rica and Panama. - Bulletin of the University of Nebraska State Museum 16: 1-506. https://digitalc ommons.unl.edu/cgi/viewcontent.cgi? article $=1000 \&$ context $=$ museumbulletin.

Ratcliffe, B.C. \& R.D. Cave, 2006. The dynastine scarab beetles of Honduras, Nicaragua and El Salvador. Bulletin of the University of Nebraska State Museum 21: 1-424.

Ratcliffe, B.C. \& R.D. Cave, 2015. The dynastine scarab beetles of the West Indies (Coleoptera: Scarabaeidae: Dynastinae). - Bulletin of the University of Nebraska State Museum 28: 1-346.

Régimbart, M., 1889. Descriptions de dytiscides nouveaux de l'Amérique du Sud. - Annales de la Société Entomologique de France Ser. 6, 8: 388-392. https://www .biodiversitylibrary.org/page/8241136.

Reichardt, H., 1967. A monographic revision of the American Galeritini (Coleoptera, Carabidae). - Arquivos de Zoologia 15: 1-176. doi: 10.11606/issn.2176-7793. v15i1-2p1-176.
Reiche, L.J., 1842. Coléoptères de Colombie. - Revue Zoologique 5: 238-242. https://www.biodiversitylibrary .org/page/14714769.

Reiche, L.J., 1853. Note sur l'Hybosorus arator auctorum, et sur le Trox granulatus, F., et description d'une nouvelle espèce. - Annales de la Société Entomologique de France Ser. 3, 1: 87-90. https://www.biodiversity library.org/page/8310965.

Reitter, E., 1873a. Die Rhizophaginen, monographisch bearbeitet. - Verhandlungen des Naturforschenden Vereines in Brünn 11 [1872]: 27-48. https:/www.bio diversitylibrary.org/page/43910447.

Reitter, E., 1873b. Systematische eintheilung der Nitidularien. - Verhandlungen des Naturforschenden Vereines in Brunn 12: 3-194. https://www.biodiversityli brary.org/page/43552059.

Reitter, E., 1878. Coleopterorum species novae. Verhandlungen der Kaiserlich-Königlichen ZoologischBotanischen Gesellschaft in Wien 27 [1877]: 165-194. https://www.biodiversitylibrary.org/page/26709010.

Reitter, E., 1883. Beitrag zur Kenntniss der Clavigeriden, Pselaphiden und Scydmaeniden von Westindien. Deutsche Entomologische Zeitschrift 27: 33-46. https://www.biodiversitylibrary.org/page/33215531.

Reitter, E., 1909. Fauna Germanica. Die Käfer des Deutschen Reiches. Nach der analytischen Methode bearbeitet. II. Band. - K.G. Lutz, Stuttgart, Germany, 392 pp. + pls. 41-80. http://publikationen.ub.uni -frankfurt.de/files/9219/reitter2_high-compressed.pdf.

Rheinheimer, J., 2014. Les Curculionoidea de Martinique (Coleoptera). - Contribution à l'étude des Coléoptères des Petites Antilles (supplément a Le Coléoptériste) 2: 46-76.

Ribeiro-Costa, C.S., D. Manfio \& G. Morse, 2018. Catalog for the Brazilian Amblycerus Thunberg (Coleoptera: Chrysomelidae: Bruchinae) with taxonomic notes, host plants associations and distributional records. - Zootaxa 4388: 499-525. doi: 10.11646/zootaxa.4388.4.3.

Rigatti-Luchini, S. \& A. Camuffo, 1962. Appunti sulla variabilita dell'Epitragus aurulentus K. (Coleotteri Tenebrionidi). - Monitore Zoologico Italiano 69: 90-102.

Roda, A., M. Kairo, T. Damian, F. Franken, K. Heidweiller, C. Johanns \& R. Mankin, 2011. Red palm weevil (Rhynchophorus ferrugineus), an invasive pest recently found in the Caribbean that threatens the region. - EPPO Bulletin 41: 116-121. doi: 10.1111/ j.1365-2338.2011.02446.x.

Rodriguero, M.S., A.A. Lanteri, N.V. Guzmán, J.V. Carús Guede \& V.A. Confalonieri, 2016. Out of the forest: past and present range expansion of a parthenogenetic weevil pest, or how to colonize the world successfully. - Ecology and Evolution 6: 5431-5445. doi: 10.1002/ ece3.2180.

Roelofs, W., 1875. Note sur les Curculionides recueillis par M. Purves à l'île d'Antigua. - Comptes-Rendus des Séances de la Société Entomologique de Belgique 1875: xxv-xxvi. https:/www.biodiversitylibrary.org/ page/ 12720628 . 
Rojer, A., 1997a. Biological inventory of Saba. KNAP project 96-10. - Carmabi Foundation, Curaçao, 86 pp. https:/www.dcbd.nl/sites/www.dcbd.nl/files/doc uments/Rojer\%201997\%20Biological\%20Inven tory\%20Saba.PDF.

Rojer, A., 1997b. Biological inventory of Sint Eustatius. KNAP project 96-10. - Carmabi Foundation, Curaçao, 92 pp. https://www.dcbd.nl/sites/www.dcbd.nl/ files/documents/Rojer\%25201997\%2520Biological\% 2520 inventory $\% 2520$ of\% 2520 St $\% 2520$ Eustatius. pdf.

Rojer, A., 1997c. Biological inventory of St. Maarten. KNAP project 96-10. - Carmabi Foundation, Curaçao, $98 \mathrm{pp}$. https://www.dcbd.nl/sites/www.dcbd .nl/files/documents/RojerKNAP96-33BioInv-St Maarten\%5Beng\%5D.pdf.

Romero, J. \& C.D. Johnson, 2000. Revision of the genus Zabrotes Horn of Mexico (Coleoptera: Bruchidae: Amblycerinae). - Transactions of the American Entomological Society 126 (2): 221-274. https://www.jstor .org/stable/25078712.

Romero, J. \& C.D. Johnson, 2004. Checklist of the Bruchidae (Insecta: Coleoptera) of Mexico. - Coleopterists Bulletin 58 (4): 613-635. doi: 10.1649/694.

Romero Nápoles, J., 2018. Revisión del género Zabrotes para México (Coleoptera: Bruchidae). Comisión nacional para el conocimiento y uso de la biodiversidad. - Occurrence dataset. doi: 10.15468/hhzwhp accessed via GBIF.org on 2020-02-02.

Roobol, M.J. \& A.L. Smith, 2004. Volcanology of Saba and St. Eustatius, Northern Lesser Antilles. - Koninklijke Nederlandse Akademie voor Wetenschappen, Amsterdam, The Netherlands, $\mathrm{xx}+320 \mathrm{pp}$.

Roy, H., 2020. Record with photo on iNaturalist. - https:// www.inaturalist.org/observations/38101590.

Rücker, H.W., 1988. Eine neue Art der Gattung Holoparamecus Curtis aus Curaçao, Niederländische Antillen (Coleoptera: Merophysiidae). - Revue Suisse de Zoologie 95: 1027-1029. https://www.biodiversitylibrary .org/page/41313649.

Rutherford, M. \& R.J. Auguste, 2018a. UWIZM Scarabaeidae Beetles. Version 1.3. The University of the West Indies Zoology Museum (UWIZM). - Occurrence dataset. doi: $10.15468 /$ vutm $1 \mathrm{z}$ accessed via GBIF.org on 2020-02-05.

Rutherford, M. \& R.J. Auguste, 2018b. UWIZM Chrysomelidae Beetles. Version 1.3. The University of the West Indies Zoology Museum (UWIZM). - Occurrence dataset. doi: 10.15468/m1 oyue accessed via GBIF.org on 2020-02-05.

Rutten, L.M.R., 1932. Een geologische reis met Utrechtsche studenten naar de Nederlandsche Benedenwindsche Eilanden. - West-Indische Gids 13: 289-309. doi: 10.1163/22134360-90001107.

Sagarra, L.A. \& D.D. Peterkin, 1999. Invasion of the Carribean by the hibiscus mealybug, Maconellicoccus hirsutus Green (Homoptera: Pseudococcidae). Phytoprotection 80: 103-113. doi: 10.7202/706 185ar.
Sahlberg, C.R., 1823. Periculi entomographici, species insectorum nondum descriptas proposituri, fasciculus. Frenckell, Turku [Aboae], Finland, 82 pp. https://www .biodiversitylibrary.org/page/10990686.

Santiago-Blay, J.A., T.J. Henry \& A.G. Wheeler, 1997. Obituary. Jenaro Maldonado Capriles 1919-1995: Biographical sketch, patronyms in his honor, and list of publications. - Proceedings of the Entomological Society of Washington 99 (4): 762-771. https://www .biodiversitylibrary.org/page/16213437.

Santos-Silva, A., I.P. Swift \& E.H. Nearns, 2010. Division of the genus Nothopleurus Lacordaire, 1869 (Coleoptera: Cerambycidae: Prioninae). - Zootaxa 2643: 1-44. doi: 10.11646/zootaxa.2643.1.1.

Sarkiss, A., 2018. Record with photo on iNaturalist. https://www.inaturalist.org/observations/19157184.

Sartori, M. \& D. Cherix, 1983. Histoire de l'étude des insects sociaux en Suisse à travers l'oeuvre d'Auguste Forel. - Bulletin de la Société Entomologique de France 88: 66-74. https://www.persee.fr/doc/bsef _0037-928x_1983_num_88_1_18287.

Saunders, E., 1869. Descriptions of ten new species of the genus Paracupta, H. Deyrolle, and of ten new species of the genus Conognatha, Escholtze. - Journal of the Linnaean Society of London, Zoology 10: 331-341. doi: 10.1111/j.1096-3642.1869.tb00 664.x.

Say, T. 1824. Appendix. Part I. Natural History. 1. Zoology. E. Class Insecta. Order Coleoptera. - In: W.H. Keating (Ed.), Narrative of an expedition to the source of St. Peters River, Lake Winnepeck, Lake of the Woods \&c. \&c. performed in the year 1823 , by order of the Hon. J.C. Calhoun, Secretary of War, under the command of Stephen H. Long, Major U.S.T.E. Compiled from the notes of Major Long, Messrs. Say, Keating, and Colhoun, by William H. Keating. Vol. II: pp. 268-378. - H.C. Carey \& I. Lea, Philadelphia, PA, USA. https://www.biodiversitylibrary.org/ page/13640703.

Say, T., 1826. Descriptions of new species of coleopterous insects inhabiting the United States. - Journal of the Academy of Natural Sciences of Philadelphia 5: 237-284. https://www.biodiversitylibrary.org/page/ 24657295 .

Say, T., 1831. Descriptions of new species of North American insects, and observations on some of the species already described. [Part 2]: pp. 42-49. - New Harmony, IN, USA. https://www.biodiversitylibrary.org/ page/52268177.

Say, T., 1835. Descriptions of new North American coleopterous insects, and observations on some already described. - Boston Journal of Natural History 1: 151-203. https://www.biodiversitylibrary.org/ page/32413875.

SCAN, 2020. Symbiota Collections of Arthropods Network. - Digital publication available at https://scan -bugs.org/portal/index.php.

Scannell, P., 2018. Records with photo on iNaturalist. https://www.inaturalist.org/observations/33658346. 
Scannell, P., 2019. Records with photo on iNaturalist. https://www.inaturalist.org/observations/36111549.

Scannell, P., 2020. Records with photo on iNaturalist. https://www.inaturalist.org/observations/38012283, https://www.inaturalist.org/observations/38011657.

Schaaf, D., 1971. Revision of the genus Physorhinus (Coleoptera, Elateridae) in North, Central, and South America. Part II: Descriptions. - Entomological News 82: 57-84. https://www.biodiversitylibrary.org/ page/2701101.

Schaeffer, C.F.A., 1907. New Bruchidae with notes on known species and list of species known to occur at Brownsville, Texas, and in the Huachuca Mountains, Arizona. - Science Bulletin of the The Museum of the Brooklyn Institute of Arts and Sciences 1: 291-306.

Schedl, K.E., 1938. Die Einteilung der Pityophthorinae. Archiv für Naturgeschichte (NF) 7: 157-188.

Schedl, K.E., 1957. A few Scolytidae from the West Indies. - Journal of the New York Entomological Society 65: 191-194. https://www.biodiversitylibrary.org/ page/ 50810615 .

Scheerpeltz, O., 1952. Revision der Gattung Piestus Gravh. (Coleoptera Staphylinidae). - Revista Chilena de Entomologia 2: 281-305. https://www.biodiversitylibrary .org/page/32160634.

Schilsky, J., 1905. Die Käfer Europa's. Nach der Natur beschrieben von Dr. H.C. Küster \& Dr. G. Kraatz. Einundvierzigstes Heft. - Bauer \& Raspe, Nürnberg, Germany, iv + [476] pp. https://www.biodiversityli brary.org/page/49126563.

Schmitt, W.L., 1958. Smithsonian-Bredin Caribbean Expedition, 1958. Station data. - In: Waldo L. Schmitt Papers, 1907-1978. Smithsonian Field Book Project. Available at https://biodiversitylibrary.org/biblio graphy/131838/.

Schmutz, P.P., A.E. Potter \& E.A. Modlin Jr., 2017. Aruba, Bonaire, and Curaçao. - In: C.D. Allen (Ed.), Landscapes and landforms of the Lesser Antilles: pp. 293317. Springer International Publishing, Cham, Switzerland. doi: 10.1007/978-3-319-55787-8_18.

Schönherr, C.J., 1806. Synonymia insectorum oder: Versuch einer Synonymie aller bisher bekannten Insecten; nach Fabricii Systema Eleutheratorum geordnet. Mit Berichtigungen und Anmerkungen, wie auch Beschreibungen neuer Arten und illuminirten Kupfern. Erster Band. Eleutherata oder Käfer. Erster Theil. Lethrus... Scolytes. - Heinr. A. Nordström, Stockholm, Sweden, xxii + 293 pp. https://www.biodiversitylibrary .org/page/42218536.

Schönherr, C.J., 1823. Curculionides. Tabula synoptica familiae curculionidum. - Isis von Oken 1823: cols. 1132-1146. https://www.biodiversitylibrary.org/page/ 13257284.

Schönherr, C.J., 1825. Continuatio tabulae synopticae familiae curculionidum. - Isis von Oken 1825: cols. 581-588. https://www.biodiversitylibrary.org/ page/27509108.

Schönherr, C.J., 1826. Curculionidum dispositio methodica, cum generum characteribus, descriptionibus atque observationibus variis, seu prodromus ad Synonymiae
Insectorum partem IV. - Fridericum Fleischer, Leipzig, Germany, $\mathrm{x}+338$ pp. https://www.biodiversitylibrary .org/page/9877808.

Schönherr, C.J., 1836. Genera et species curculionidum, cum synonymia hujus familiae. Species novae aut hactenus minus cognitae, descriptionibus a Dom. Leonardo Gyllenhal, C.H. Boheman, et entomologis aliis illustratae. Tomus tertius. Pars secunda: pp. 507-858. - Roret, Paris, France. https://www.biodiversitylibrary .org/page/9442869.

Schönherr, C.J., 1840. Genera et species curculionidum, cum synonymia hujus familiae; species novae aut hactenus minus cognitae, descriptionibus A Dom. Leonardo Gyllenhal, C.H. Boheman, et entomologis aliis illustratae. Tomus sextus. Pars prima. Supplementum continens. - Roret, Paris, France, [2] + 474 pp.

Schönherr, C.J., 1843. Genera et species curculionidum, cum synonymia hujus familiae. Species novae aut hactenus minus cognitae, descriptionibus A Dom. Leonardo Gyllenhal, C.H. Boheman, et entomologis aliis illustratae. Tomus septimus. Pars secunda. Supplementum continens. - Roret, Paris, France, 461 pp.

Schwarz, E.A., 1894. Descriptions of two rhynchophorous Coleoptera from semitropical Florida. - Proceedings of the Entomological Society of Washington 3: 42-45. https://www.biodiversitylibrary.org/page/2360321.

SEAG, 2020. Société entomologique Antilles-Guyane. Digital publication available at http://insectafgseag .myspecies.info/.

Seidlitz, G., 1872. Fauna Baltica. Die Käfer (Coleoptera) der Ostseeprovinzen Russlands. - H. Laakmann, Dorpat, Germany, xlii + 142 [Gattungen] + 560 [Arten, Register] pp. + 1 pl. https://books.google.nl/books/ download/Fauna_Baltica.pdf?id=KvtGAQAAMAAJ\& output=pdf.

Sekerka, L. \& M.V.L. Barclay, 2014. Fabrician types of Cassidinae (Coleoptera: Chrysomelidae) deposited in the Natural History Museum, London. - Acta Entomologica Musei Nationalis Pragae 54 (2): 657-684. https:// www.aemnp.eu/data/article-1525/1506-54_2_657 .pdf.

Sharp, D., 1876. Contributions to an insect fauna of the Amazon Valley. Coleoptera-Staphylinidae. - Transactions of the Royal Entomological Society of London 24: 27-424. doi: 10.1111/j.1365-2311.1876 .tb01123.x.

Sharp, D., 1882. On aquatic carnivorous Coleoptera or Dytiscidae. - Scientific Transactions of The Royal Dublin Society Ser. 2, 2: 179-1003. https:/www.bio diversitylibrary.org/page/10137417.

Sharp, D., 1885. Tribe Bruchides. - In: F.D. Godman \& O. Salvin (Eds), Biologia Centrali-Americana Insecta Coleoptera, Vol. V: pp. 437-504. R.H. Porter, London, UK. https://www.biodiversitylibrary.org/page/584 438.

Sharp, D., 1889. Litolibrus, gen. nov. - In: F.D. Godman \& O. Salvin (Eds), Biologia Centrali-Americana Insecta Coleoptera, Vol. II. Part I: pp. 258-259. Taylor and Francis, London, UK. https://www.biodiversityli brary.org/page/578175. 
Sharp, D., 1902. Eucnocerus anthrenoides. - In: F.D. Godman \& O. Salvin (Eds), Biologia Centrali-Americana Insecta Coleoptera, Vol. II. Part I: p. 649. R.H. Porter, London, UK. https://www.biodiversitylibrary.org/ page/ 578566 .

Sherborn, C.D., 1929. Index animalium sive index nominum quae ab A.D. MDCCLVIII generibus et speciebus animalium imposita sunt societatibus eruditorum adiuvantibus. Sectio secunda. A kalendis lanuariis, MDCCCI usque ad finem Decembris, MDCCCL. Part XX: pp. 4931-5138. Index phyllochromaPratincola. - Trustees of the British Museum, London, UK. https://www.biodiversitylibrary.org/page/3621 2779.

Sherman, M. \& M. Tamashiro, 1954. The sweetpotato weevils in Hawaii. Their biology and control. Technical Bulletin 23. - Hawaii Agricultural Experiment Station, University of Hawaii, pp. 1-36. https://scholarspace .manoa.hawaii.edu/bitstream/10125/14975/TB-23 .pdf.

Shpeley, D. \& G.E. Ball, 2000. A taxonomic review of the subtribe Pericalina (Coleoptera: Carabidae: Lebiini) in the Western Hemisphere, with descriptions of new species and notes about classification and zoogeography. - Insecta Mundi 14: 1-185. https://journals.flvc.org/mundi/article/view/24933/2 4264.

Shpeley, D., W. Hunting \& G.E. Ball, 2017. A taxonomic review of the Selenophori group (Coleoptera, Carabidae, Harpalini) in the West Indies, with descriptions of new species and notes about classification and biogeography. - ZooKeys 690: 1-195. doi: $10.3897 /$ zookeys.690.13751.

Sicard, A., 1929. Description d'espèces nouvelles de Coccinellidae. - Annals and Magazine of Natural History (10) 4: 515-524. doi: 10.1080/0022293290867 3088.

Sieben, H., 2016. Record with photo on the citizen science website Observation.org. - https://observation.org/ waarneming/view/125987431.

Signoret, V.A., 1869. Essai sur les cochenilles ou gallinsectes (Homoptères - Coccides). 4e partie. - Annales de la Société Entomologique de France (4) 9: 109138. https://www.biodiversitylibrary.org/page/3254 6669.

Sikes, D., 2020a. UAM Insect Observations (Arctos). Version 36.35. University of Alaska Museum of the North. - Occurrence dataset. doi: 10.15468/8nv0mp accessed via GBIF.org on 2020-02-06.

Sikes, D., 2020b. ResearchGate profile. - available at https://www.researchgate.net/profile/Derek_Sikes.

Simon Thomas, R.T., 1984. Notes on the Hymenoptera Aculeata from St. Martin, Saba, and St. Eustatius. Studies on the Fauna of Curaçao and other Caribbean Islands 67: 92-97. http://www.repository.naturalis.nl/ document $/ 549993$.

Skelley, P.E., 2020. Nomenclatural notes for the Erotylinae (Coleoptera: Erotylidae). - Insecta Mundi 767: 1-35. https://journals.flvc.org/mundi/article/view/ $122881 / 121838$.
Skelton, P.W., E. Robinson \& J. Krijnen, 2013. Obituary: Henry James Mac Gillavry (Mac) 12th June, 190824th January, 2012. - Caribbean Journal of Earth Science 45: 125-129. http://caribjes.com/CJESpdf/ CJES45-13-Mac.pdf.

Skilling, D.D. \& H.O. Batzer, 1995. World directory of forest pathologists and entomologists. - International Union of Forestry Research Organizations / USDA Forest Service, ix + 210 pp. https://books.google.nl/ books? id=R9vx2j83YFQC\&printsec $=$ frontcover\&so urce $=\mathrm{gbs} \_g e \_s u m m a r y \_r \& c a d=0 \# v=$ onepage $\& \mathrm{q} \& \mathrm{f}=$ false.

Slowik, J. \& D.S. Sikes, 2011. Spiders (Arachnida: Araneae) of Saba Island, Lesser Antilles: Unusually high species richness indicates the Caribbean Biodiversity Hotspot is woefully undersampled. - Insecta Mundi 177: 1-9. https://journals.flvc.org/mundi/article/ view/0177/0177/73913.

Smith, A.Z., 1986. A history of the Hope entomological collections in the University Museum, Oxford, with lists of archives and collections. - Clarendon Press, Oxford, xiii + 172 pp.

Smith, T.R., 2007. Cybocephalus caribaeus. - In: T.R. Smith \& R.D. Cave, The Cybocephalidae (Coleoptera) of the West Indies and Trinidad. - Annals of the Entomological Society of America 100: 167-168. doi: 10.1603/0013-8746(2007)100[164:TCCOTW]2.0. $\mathrm{CO} ; 2$.

Smith, T.R. \& R.D. Cave, 2007. The Cybocephalidae (Coleoptera) of the West Indies and Trinidad. - Annals of the Entomological Society of America 100: 164-172. doi: 10.1603/0013-8746(2007) 100[164:TCCOTW]2.0.CO;2.

Soldati, L. \& J. Touroult, 2014. Catalogue des coléoptères Tenebrionidae (Alleculinae exclus) des Antilles françaises. - Contribution à l'étude des Coléoptères des Petites Antilles (supplément a Le Coléoptériste) 2: 90-108.

Solier, A.J.J., 1835a. Description de quelques espèces nouvelles de la famille des carabiques. - Annales de la Société Entomologique de France 4: 111-121. https:// www.biodiversitylibrary.org/page/8311833.

Solier, A.J.J., 1835b. Prodrome de la famille des Xystropides. - Annales de la Société Entomologique de France 4: 229-248. https://www.biodiversitylibrary.org/page/ 8311951.

Spangler, P.J., 1960. A revision of the genus Tropisternus (Coleoptera: Hydrophilidae). - PhD Thesis, University of Missouri, Columbia, SC, USA, 364 pp.

Spiessberger, E.L. \& M.A. Ivie, 2018. Revision of the West Indian Cyrtosoma Perty (Coleoptera: Tenebrionidae: Cnodalonini), with descriptions of three new species. - The Coleopterists Bulletin 72: 825-837. doi: 10.1649/0010-065X-72.4.825.

Spilman, T.J., 1973. Nomenclatural problems in six genera of Tenebrionidae (Coleoptera). - Proceedings of the Entomological Society of Washington 75: 39-44. https://www.biodiversitylibrary.org/page/16290699.

Staines, C.L. \& A.E. Whittington, 2003. Chrysomelidae (Coleoptera) types in the Royal Museum of Scotland Downloaded from Brill.com04/26/2023 08:17:17AM via free access 
Collection. - Zootaxa 192: 1-8. doi: 10.11646/ zootaxa.192.1.1.

Stebbing, E.P., 1914. Indian forest insects of economic importance. Coleoptera. - Eyre and Spottiswoode, London, UK, xvi + 648 pp. https://www.biodiversityli brary.org/page/9787225.

Stebnicka, Z., 2006. The New World species of Ataenius Harold, 1867. VII. Revision of the A. complicatus-group (Scarabaeidae: Aphodiinae: Eupariini). - Acta Zoologica Cracoviensia 49: 89-114. doi: 10.3409/000000006783995364.

Stein, J.P.E.F. \& J. Weise, 1877. Catalogi coleopterorum Europae. Editio secunda. - Libraria Nicolai, Berlin, Germany, iv + 209 pp. https://books.google.nl/books/ download/Catalogi_coleopterorum_Europae.pdf?id= 7BBpAAAAIAAJ\&hl=nl\&output=pdf.

Steiner, W. 2020. ResearchGate profile. - available at https://www.researchgate.net/profile/Warren_Steiner.

Stephens, J.F., 1830. Illustrations of British entomology or, a synopsis of indigenous insects: containing their generic and specific distinctions; with an account of their metamorphoses, times of appearance, localities, food, and economy, as far as practicable. Mandibulata. Vol. III. - Baldwin and Cradock, London, UK, 447 pp. + xvi-xix pls. https://www.biodiversitylibrary.org/ page/30972182.

Stock, J.H., 1977. The taxonomy and zoogeography of the hadziid Amphipoda, with emphasis on the West Indian taxa. - Studies on the Fauna of Curaçao and other Caribbean Islands 55: 1-130. http://www.repository .naturalis.nl/document/549856.

Stoffers, A.L., 1956. The vegetation of the Netherlands Antilles. - Uitgaven Natuurwetenschappelijke Studiekring voor Suriname en de Nederlandse Antillen 15: 1-142. http://repository.naturalis.nl/document/ 550089.

Suffrian, E., 1852. Zur Kenntniss der nordamerikanischen Cryptocephalen (Schluss). - Linnaea Entomologica 7: 1-238. https://www.biodiversitylibrary.org/ page/44483770.

Suffrian, E., 1868. Verzeichniss der von Dr. Gundlach auf der Insel Cuba gesammelten Chrysomelinen. Schluss. - Archiv für Naturgeschichte 34: 163-252. https:// www.biodiversitylibrary.org/page/6667810.

Suffrian, E., 1870. Verzeichniss der von Dr. Gundlach auf der Insel Cuba gesammelten Rüsselkäfer. - Archiv für Naturgeschichte 36: 150-234. https://www.biodi versitylibrary.org/page/7082045.

Suringar, W.F.R., 1885. [Voordracht van Prof. Suringar over zijn reis naar West-Indië (verslag)]. - Tijdschrift van het Koninklijk Nederlands Aardrijkskundig Genootschap Ser. 2, 2: 548-550.

Suringar, W.F.R., 1886. Nederlandsch West-Indische Expeditie. Verslag en reisverhaal. - Tijdschrift van het Koninklijk Nederlands Aardrijkskundig Genootschap Ser. 2, 3: 45-90, 355-394, 511-545.

Telenius, A. \& M. Shah, 2016. Zoology (Museum of Evolution - Uppsala). GBIF-Sweden. - Occurrence dataset. https://doi.org/10.15468/1 rofux accessed via GBIF .org on 2020-02-07.
Terán, A.L. \& J.M. Kingsolver, 1992. Algunas novedades en el genero Megacerus (Coleoptera, Bruchidae). - Acta Zoologica Lilloana 42: 19-27.

Terpstra, M., 2013a. Records with photo on the citizen science website Observation.org. - https://observa tion.org/waarneming/view/80409545, https://observa tion.org/waarneming/view/80480779, https://obser vation.org/waarneming/view/80226556, https://obser vation.org/waarneming/view/80400317, https://obser vation.org/waarneming/view/80410713.

Terpstra, M., 2013b. Record with photo on iNaturalist. - https://www.inaturalist.org/observations/445753, https://www.inaturalist.org/observations/431771.

Thomas, J., 2020. Snow Entomological Museum Collection. Version 26.35. University of Kansas Biodiversity Institute. Occurrence dataset. - doi: $10.15468 /$ fhntpy accessed via GBIF.org on 2020-02 $-06$.

Thomas, M.C., R. H. Turnbow, Jr. \& W. Steiner, 2013. An annotated checklist of the Coleoptera (Insecta) of the Cayman Islands, West Indies. - Insecta Mundi 280: 1-56. https://journals.flvc.org/mundi/article/ view/0280/78686.

Thomson, C.G., 1859. Skandinaviens Coleoptera, synoptiskt bearbetade. I. Tom. - Berlingska Boktryckeriet, Lund, Sweden, 290 pp. https://www.biodiversityli brary.org/page/54335801.

Thomson, C.G., 1860. Skandinaviens Coleoptera, synoptiskt bearbetade. II. Tom. - Berlingska Boktryckeriet, Lund, Sweden, 304 pp. https://www.biodiversityli brary.org/page/54328819.

Thunberg, C.P., 1795. D.D. Dissertatio entomologica sistens insecta Svecica. Quorum partem nonam, venia exp. Ord. med. Upsal. Praeside Carol. Pet. Thunberg. Publico examini subjicit Steno Edvardus Westman, Stockholmiensis. In audit. Botanico die 20 Maji 1795. H.a.m.c. - Joh. Fred. Edman, Uppsala, Sweden, pp. 105-113. https://www.biodiversitylibrary.org/ page/ 11970070 .

Thunberg, C.P., 1808. Coccinella connectens. - In: C.J. Schönherr, Synonymia insectorum oder: Versuch einer Synonymie aller bisher bekannten Insecten; nach Fabricii Systema Eleutheratorum \&c. geordnet. Mit Berichtigungen und Anmerkungen, wie auch Beschreibungen neuer Arten und illuminirten Kupfern. Erster Band. Eleutherata oder Käfer. Zweiter Theil. Spercheus ... Cryptocephalus: p. 157. Carl Friedr. Marquard, Stockholm, Sweden. https://www.biodiversityli brary.org/page/42206750.

Touroult, J., 2012. Longicornes des Petites Antilles: mise à jour des connaissances (Coleoptera, Cerambycidae). Contribution à l'étude des Coléoptères des Petites Antilles (supplément a Le Coléoptériste) 1: 70-85. https://www.researchgate.net/profile/Julien_Touroult/ publication/311909775_Longicornes_des_Petites _Antilles_mise_a_jour_des_connaissances_Coleop tera_Cerambycidae/links/5cf162cca6fdcc8475fb76d3/ Longicornes-des-Petites-Antilles-mise-a-jour -des-connaissances-Coleoptera-Cerambycidae .pdf. 
Touroult, J.N., 2019a. Inventaire National du Patrimoine Naturel (2020). Observations naturalistes et collection entomologique de Julien Touroult. Version 1.1. UMS PatriNat (OFB-CNRS-MNHN), Paris, France. Occurrence dataset. doi: 10.15468/tst38j accessed via GBIF.org on 2020-02-05.

Touroult, J.N., 2019b. Inventaire National du Patrimoine Naturel (2019). Inventaire des Coléoptères Longicornes des Antilles françaises. Version 1.1. UMS PatriNat (OFB-CNRS-MNHN), Paris, France. Occurrence dataset. doi: 10.15468/epecit accessed via GBIF.org on 2020-02-05.

Triplehorn, C.A. 1980. [Part of the] Ohio State C.A. Triplehorn Insect Collection. - https://scan-bugs .org/portal/collections/individual/index.php?occid= 23551980\&clid $=0$.

Triplehorn, C.A. \& L.E. Watrous, 1979. A synopsis of the genus Phaleria in the United States and Baja, California (Coleoptera: Tenebrionidae). - Coleopterists Bulletin 33: 275-295. https://www.jstor.org/stable/4000097.

Tromp, M. 2019. Record with photo on iNaturalist. https://www.inaturalist.org/observations/21094989.

UGCA, 2020. University of Georgia Collection of Arthropods. - Occurrence dataset. doi: 10.15468/rsljus accessed via GBIF.org on 2020-02-02.

UPRM 2020. University of Puerto Rico Mayagüez Invertebrate Collection. - Occurrence dataset. https:// www.gbif.org/dataset/43e54c60-d6e0-41df-80a3 -ca9487a3342a accessed via GBIF.org on 2020-02-05.

Urban, I., 1902. Notae biographicae peregrinatorum Indiae Occidentalis botanicorum. - In Symbolae Antillanae, seu, Fundamenta florae Indiae Occidentalis, Vol. 3: pp. 14-158. Borntraeger, Leipzig, Germany. https:// www.biodiversitylibrary.org/page/3458128.

Valentine, B.D. \& M.A. Ivie, 2005. Beetles: Coleoptera. - In: J. Lazell (Ed.), Island. Fact and theory in nature: pp. 274-282. University of California Press, Berkeley, CA, USA.

van Andel, T., B. van der Hoorn, M. Stech, S. Bantjes Arostegui \& J. Miller, 2016. A quantitative assessment of the vegetation types on the island of St. Eustatius, Dutch Caribbean. - Global Ecology and Conservation 7: 59-69. doi: 10.1016/j .gecco.2016.05.003.

van Buurt, G. \& A.O. Debrot, 2012. Introduced agricultural pests, plant and animals diseases and vectors in the Dutch Caribbean, with an "Alert species" list. Report number C193/11, IMARES Wageningen UR, Wageningen, The Netherlands, 35 pp. https://edepot .wur.nl/200421.

van den Branden, C., 1885. Catalogue des coléoptères carnassiers aquatiques (Haliplidae, Amphizoidae, Pelobiidae et Dytiscidae). - Annales de la Société Entomologique de Belgique 29: 5-116. https://www.biodi versitylibrary.org/page/12736372.

van der Beek, J., 2018. Record with photo on the citizen science website Observation.org. - https://observation .org/waarneming/view/163528081.

van der Steen, L.J., 1988. Dr. Pieter Wagenaar Hummelinck, some biographical notes. - In: L.J. van der
Steen \& P. Wagenaar Hummelinck (Eds), Studies in honour of Dr. Pieter Wagenaar Hummelinck: pp. 1-13. Natuurwetenschappelijke Studiekring voor Suriname en de Nederlandse Antillen, Amsterdam, The Netherlands.

van Heekeren, H.R., 1960. Studies on the archaeology of the Netherlands Antilles: II. Notes on the pottery of Aruba, Curaçao and Bonaire. A survey of the nonceramic artifacts of Aruba, Curaçao and Bonaire. Uitgaven van de Natuurwetenschappelijke Werkgroep Nederlandse Antillen 10: 103-120.

van Lenteren, J.C. \& V.H.P. Bueno, 2020. Biological control in the remaining Caribbean islands. - In: J.C. van Lenteren, V.H.P. Bueno, M.G. Luna \& Y.C. Colmenarez (Eds), Biological control in Latin America and the Caribbean: its rich history and bright future: $\mathrm{pp}$. 403-425. CAB International, Wallingford, UK. doi: $10.1079 / 9781789242430.0403$.

Vandenberg, N.J., 2002. Coccinellidae Latreille 1807. In: Arnett, R.H., Jr., M.C. Thomas, P.E. Skelley \& J.H. Frank (Eds). American beetles, Vol. 2. Polyphaga: Scarabaeoidea through Curculionoidea: pp. 371-389. CRC Press,, Boca Raton, FL, USA.

Vandenberg, N.J. \& P.E. Hanson, 2019. Overview of the lady beetle tribe Diomini (Coleoptera: Coccinellidae) and description of a new phytophagous, silk-spinning genus from Costa Rica that induces food bodies on leaves of Piper (Piperaceae). - Zootaxa 4554: 255-285. doi: 10.11646/zootaxa.4554.1.9.

Vaurie, P., 1962. A revision of the genus Trox in South America (Coleoptera, Scarabaeidae). - Bulletin of the American Museum of Natural History 124: 105167. http://digitallibrary.amnh.org/handle/2246/ 1210 .

Vaurie, P., 1970. Weevils of the tribe Sipalini (Coleoptera, Curculionidae, Rhynchophorinae). Part 1. The genera Rhinostomus and Yuccaborus. - American Museum Novitates 2419: 1-57. http://digitallibrary.amnh.org/ handle/2246/2629.

Vázquez, L.L. \& S. Monteagudo, 1988. Xylosandrus compactus (Coleoptera: Scolytidae): nuevo insecto dañino para el cafeto en Cuba. - Revista de Protección Vegetal 3: 67-73.

Viana, M.J., 1968. Revisión sistemática de las "Eugenysini” Spaeth con nuevas especies y catálogo bibliográfico de las tribus (Coleopt., Chrysomelidae, Cassidinae). Revista del Museo Argentino de Ciencias Naturales "Bernardino Rivadavia” 3: 1-106.

Villiers, A., 1979a. Coléoptères Cerambycidae des Petites Antilles. Nouvelles espèces. Désignation de types. (Première note). - Revue Française d'Entomologie (N.S.) 1: 23-26.

Villiers, A., 1979b. Coléoptères Cerambycidae des Petites Antilles. Nouveau genre. Désignation de types. (Deuxième note). - Revue Française d'Entomologie (N.S.) 1: 96-98.

Villiers, A., 1980a. Coléoptères Cerambycidae des Antilles Françaises II. Cerambycinae. - Annales de la Société Entomologique de France (N.S.) 16: 265306. 
Villiers, A., 1980b. Coléoptères Cerambycidae des Antilles Françaises I. Parandrinae, Prioninae, Lepturinae. - Annales de la Société Entomologique de France (N.S.) 16: 133-157. https://gallica.bnf.fr/ark:/12148/ bpt6k61413531/f140.image.

Villiers, A., 1980c. Coléoptères Cerambycidae des Antilles Françaises III. Lamiinae. - Annales de la Société Entomologique de France (N.S.) 16: 541-598. https:// gallica.bnf.fr/ark:/12148/bpt6k61413531/f548.item.

Villiers, A., 1980d. Coléoptères Cerambycidae des Petites Antilles. Nouveaux genres, nouvelles espèces, désignation de types (Troisième note). - Revue Française d'Entomologie (N.S.) 2: 86-98.

Vlasak, J., 2019. A new species of Elaphidion AudinetServille, 1834, from Antigua and comparison with $E$. excelsum Gahan, 1895, from Guadeloupe (Coleoptera: Cerambycidae: Elaphidiini). - Zootaxa 4688: 442446. doi: 10.11646/zootaxa.4688.3.10.

Voet, J.E., 1778. Pseudo chrysomela maculata. - In: Catalogus systematicus coleopterorum. Tomus II. Catalogue systematique des coléoptères. Tome 2. Systematische naamlijst van dat geslacht van insecten dat men torren noemt. II. Deel: p. 44, pl. 33. Bakhuysen, Den Haag, The Netherlands.

Voisin, J.-F., 1992. Notes sur les genres de la tribu des Anchonini 1. Généralités, redefinition du genre Anchonus Schoenherr et description de cinq genres et de deux sous-genres nouveaux (Coleoptera, Curculionidae). Nouvelle Revue d'Entomologie (N.S.) 9: 259-271.

Vondel, B.J. van \& P.J. Spangler, 2008. Revision of the Haliplidae of the neotropical region including Mexico (Coleoptera: Haliplidae). - Koleopterologische Rundschau 78: 69-194. https://www.zobodat.at/pdf/ KOR_78_2008_0069-0194.pdf.

Voous, K.H., 1952. Bespreking - Mimus, de Chuchubi bekijkt Curaçao door W. Holleman. R.K. Boekhandel "Sint Augustinus", Curaçao. - De West-Indische Gids 33: 233-235. https://www.jstor.org/stable/41848782.

Voous, K.H., 1955. The birds of St. Martin, Saba, and St. Eustatius. - Studies on the Fauna of Curaçao and other Caribbean Islands 6: 1-82. http://www.repository.nat uralis.nl/document $/ 549985$.

Voous, K.H., 1957. The birds of Aruba, Curaçao, and Bonaire. - Studies on the Fauna of Curaçao and other Caribbean Islands 7: 1-260. http://www.repository .naturalis.nl/document/549999.

Vrijer, P.W.F. de, 1988. In memoriam R.H. Cobben (1925-1987), een biografie en een bibliografie. Entomologische Berichten 48: 165-169. https://www .biodiversitylibrary.org/page/58316014.

Wagenaar Hummelinck, P., 1939. Boekbespreking. Alfons Gabriel, Tschogogo. Aus dem Leben der Flamingos. - West-Indische Gids 21: 322. https://www.jstor.org/ stable/41848295.

Wagenaar Hummelinck, P., 1940. General information. Studies on the Fauna of Curaçao and other Caribbean Islands 1: 1-57. http://www.repository.naturalis.nl/ document/549976.

Wagenaar Hummelinck, P., 1951. Natuurwetenschappelijke belangstelling voor de Nederland- se Antillen. -West-Indische Gids 32: 1-31. doi: 10.1163/22134360-90000150.

Wagenaar Hummelinck, P., 1955. Caribbean tiger beetles of the genus Megacephala. - Studies on the Fauna of Curaçao and other Caribbean Islands 6: 89-125. http://www.repository.naturalis.nl/document/549919.

Wagenaar Hummelinck, P., 1961. Rotstekeningen van Curaçao, Aruba en Bonaire. Deel III. - Nieuwe West-Indische Gids 41: 83-126. doi: 10.1163/22134360-90002343.

Wagenaar Hummelinck, P., 1968. Twintig jaren studiekring: 1945-1965. - Nieuwe West-Indische Gids 46: 3-11. doi: 10.1163/22134360-90002246.

Wagenaar Hummelinck, P., 1978. In memoriam Frater M. Realino. - Nieuwe West-Indische Gids 52: 58-63. doi: 10.1163/22134360-90002157.

Wagenaar Hummelinck, P., 1981. Land and fresh-water localities. - Studies on the fauna of Curaçao and other Caribbean Islands 63: 1-1331. http://www.repository .naturalis.nl/document/549952.

Wagenaar Hummelinck, P., 1982. Nieuwe West-Indische Gids: register op de jaargangen XL-LV, 1960-1981. - Nieuwe West-Indische Gids 56: 197-244. doi: 10.1163/13822373-90002102.

Wagenaar Hummelinck, P., 1983. Additional notes on Caribbean tiger-beetles of the genera Cicindela and Megacephala. - Studies on the Fauna of Curaçao and other Caribbean Islands 65: 69-135. http://www.repository .naturalis.nl/document/549840.

Wagner, H., 1910. Curculionidae: Apioninae. - Coleopterorum Catalogus. Pars 6: pp. 1-81. W. Junk, Berlin, Germany. https:/www.biodiversitylibrary.org/ page/48522293.

Wagner, H., 1913. Coleoptera Fam. Curculionidae Subfam. Apioninae. Genera Insectorum. Fascicle 130. - Verteneuil \& Desmet, Brussels, Belgium, 109 pp. + 6 pls. https://www.biodiversitylibrary.org/page/ 19141162.

Walker, F., 1858. Characters of some apparently undescribed Ceylon insects. - Annals and Magazine of Natural History Ser. 3, 2: 202-209. https:/www.bio diversitylibrary.org/page/2265176.

Wallace, A.R., 1876. The geographical distribution of animals; with a study of the relations of living and extinct faunas as elucidating the past changes of the Earth's surface, Vol. 2. - Harper \& Brothers, New York, NY, USA, viii + 607 pp. https://www.biodiversitylibrary .org/page/22937039.

Wallin, L., 2001. Catalogue of type specimens. 3. Entomology. Revised version 4. - Uppsala University Museum of Evolution, Zoology Section, Uppsala. Digital publication available at http://www.evolutionsmuseet .uu.se/samling/UUZM03_Entomology.pdf.

Waterhouse, C.O., 1874. Description of a new species of Baridius (Coleoptera: Rhynchophora) from Singapore, which destroys orchids. - Entomologist's Monthly Magazine 10: 226-227. https://www.biodiversityli brary.org/page/9271552.

Watrous, L.E. \& C.A. Triplehorn, 1982. Phaleria of the West Indies and circum-Caribbean region (Coleoptera: 
Tenebrionidae). - Coleopterists Bulletin 36: 12-21. https://www.jstor.org/stable/4007973.

Weise, J., 1885. Beitrag zur Chrysomeliden- und Coccinelliden-Fauna Portorico's. - Archiv für Naturgeschichte 51: 144-168. https://www.biodiversitylibrary.org/ page/6317058.

Weise, J., 1901. Coccinelliden aus Ceylon gesammelt von Dr. Horn. - Deutsche Entomologische Zeitschrift 44: 417-445. https://www.biodiversitylibrary.org/ page/33216671.

Wenzel, R.L., 1944. On the classification of the histerid beetles. - Field Museum of Natural History, Zoological Series 28: 51-151. https://www.biodiversitylibrary.org/ page/2777161.

Werner, F., 1925. Zur Kenntnis der Fauna der Insel Bonaire (Niederländisch-Westindien). - Zeitschrift für Wissenschaftliche Zoologie 125: 533-556.

Werner, F.G., 1966. A revision of Acanthinus (Coleoptera: Anthicidae). III. The spinicollis-group. - Annals of the Entomological Society of America 59: 1267-1276. doi: 10.1093/aesa/59.6.1267.

Westermann, J.H., 1957. De geologische geschiedenis der drie Bovenwindse eilanden St. Martin, Saba en St. Eustatius. - West-Indische Gids 37: 127-168. doi: 10.1163/22134360-90000035.

Westermann, J.H. \& H. Kiel, 1961. The geology of Saba and St. Eustatius, with notes on the geology of St. Kitts, Nevis and Montserrat (Lesser Antilles). - Uitgaven Natuurwetenschappelijke Studiekring voor Suriname en de Nederlandse Antillen 24: 1-175. https://edepot .wur.nl/484849.

Westwood, J.O., 1834 [1836]. Description of a minute coleopterous insect, forming the type of a new subgenus allied to Tomicus, with some observations upon the affinities of the Xylophaga. - Transactions of the Entomological Society of London 1: 34-36. https://www .biodiversitylibrary.org/page/13496953.

Wetmore, A., 1939. Biographical sketch of Stuart T. Danforth, 1900-1938. - Journal of Agriculture of the University of Puerto Rico 23: 1-8. https://revistas.upr.edu/ index.php/jaupr/article/view/12900.

Wheeler, G., 1912. On the dates of the publications of the Entomological Society of London. - Transactions of the Entomological Society of London 59: 750767. https://www.biodiversitylibrary.org/page/14765 840.

Wheeler, A.G. Jr., G.A. Evans \& N.J. Vandenberg, 2010. Pseudococcus saccharicola Takahashi (Hemiptera: Pseudococcidae) in the British Virgin Islands: First Western Hemisphere records, with records of a co-occurring lady beetle, Hyperaspis scutifera (Mulsant) (Coleoptera: Coccinellidae). - Proceedings of the Entomological Society of Washington 112: 565-575. doi: 10.4289/0013-8797.112.4 .565 .

White, A., 1853. Coleopterous insects in the collection of the British Museum Part VII. Longicornia I. - British Museum of Natural History, London, UK, iv + 174 pp. + 4 pls. https:/www.biodiversitylibrary.org/ page/39794281.
White, R.E., 1963. A revision of the genus Tricorynus of North America (Coleoptera: Anobiidae). - PhD Thesis, Ohio State University, USA, v + 399 pp. https://etd.ohiolink.edu/!etd.send_file?accession $=$ osu 1347380565.

White, R.E., 1984. A revision of the American genus Cryptorama (Coleoptera: Anobiidae). - Transactions of the American Entomological Society 110: 77-127. https://www.jstor.org/stable/25078334.

Wiebes, J.T., 1961. Caryoborus gonagra (F.) en Sitophilus linearis (Herbst), ingevoerd met tamarinde-vruchten uit Curaçao; met bijzonderheden ter onderscheiding van drie Sitophilus-soorten (Coleoptera, Bruchidae en Curculionidae). - Entomologische Berichten 21: 234-236.

Wilcox, J.A., 1971. Chrysomelidae: Galerucinae. - Coleopterorum Catalogus Pars 78, Fasc. 1, 2nd edn, 220 pp. Dr W. Junk, 's-Gravenhage, The Netherlands.

Winston, R.L., M. Schwarzländer, H.L. Hinz, M.D. Day, M.J.W. Cock \& M.H. Julien, 2014. Biological control of weeds. A world catalogue of agents and their target weeds, 5th edition. - USDA Forest Service, Forest Health Technology Enterprise Team, Morgantown, WV, USA, i + 838 pp.

Wisco, A., 2016. Record with photo on iNaturalist. https://www.inaturalist.org/observations/2588796.

Wolcott, G.N., 1924. "Insectae Portoricensis." A preliminary annotated check-list of the insects of Puerto Rico, with descriptions of some new species. - Journal of the Department of Agriculture of Porto Rico 7: 1313. https://revistas.upr.edu/index.php/jaupr/article/ view/15118.

Wolcott, G.N., 1936. "Insectae Borinquenses" — a revision of "Insectae Portoricensis" and "First supplement to Insectae Portoricensis". - The Journal of Agriculture of the University of Puerto Rico 20: 1-600. https:// revistas.upr.edu/index.php/jaupr/article/view/14347.

Wolcott, G.N., 1951 [1948]. The insects of Puerto Rico - Coleoptera. - The Journal of Agriculture of the University of Puerto Rico 32: 225-416. https://revistas .upr.edu/index.php/jaupr/article/view/13615.

Wollaston, T.V., 1857. Catalogue of the coleopterous insects of Madeira, in the collection of the British museum. - British Museum of Natural Natural History, London, UK, xvi + 234 pp. https://www.biodiversityli brary.org/page/10527483.

Wollaston, T.V., 1861. On certain Coleoptera from the Island of St. Vincent. - Annals and Magazine of Natural History Ser. 3, 7: 90-103. https://www.biodiversityli brary.org/page/16087075.

Wood, S.L., 1961. New species of bark beetles (Coleoptera: Scolytidae), mostly Mexican, part VI. - Great Basin Naturalist 21: 87-107. https://www.biodiversityli brary.org/page/7909455.

Wood, S.L., 1962. Miscellaneous taxonomic notes on Scolytidae (Coleoptera). - Great Basin Naturalist 22: 76-82. https://www.biodiversitylibrary.org/page/7910 102.

Wood, S.L. 1974. New species of American bark beetles (Coleoptera: Scolytidae). - Brigham Young University Downloaded from Brill.com04/26/2023 08:17:17AM 
of Science Bulletin Biology Series 19: 1-67. https:// scholarsarchive.byu.edu/cgi/viewcontent.cgi?article= $1074 \&$ context=byuscib.

Wood, S.L., 1978. New synonymy and new species of American bark beetles (Coleoptera: Scolytidae) part VII. - Great Basin Naturalist 38: 397-405. https:// www.biodiversitylibrary.org/page/7802037.

Wood, S.L., 1979. New synonymy and new species of American bark beetles (Coleoptera: Scolytidae) part VIII. - Great Basin Naturalist 39: 133-142. https:// www.biodiversitylibrary.org/page/8112598.

Wood, S.L., 2007. Bark and ambrosia beetles of South America. - M.L. Bean Life Science Museum, Brigham Young University, Provo, Utah, v +900 pp. http://www .monarthrum.info/pdf_assets/Wood\%202007\%20 south\%20america\%20bookmarked.pdf.

Wood, S.L. \& D.E. Bright, 1987. A catalog of Scolytidae and Platypodidae (Coleoptera) part 1. Bibliography. Great Basin Naturalist Memoirs 11: 1-685. https:// www.biodiversitylibrary.org/page/33885957.

Wood, S.L. \& D.E. Bright, 1992. A catalog of Scolytidae and Platypodidae (Coleoptera) part 2. Taxonomic index. - Great Basin Naturalist Memoirs 13: 1-1553. https://www.biodiversitylibrary.org/page/7947249, https://www.biodiversitylibrary.org/page/8897072.

Yokoyama, M., 2010. The incomplete guide to the wildlife of Saint Martin. Version 1.1. - Private publication, 124 pp. https://books.google.nl/books?id=D48mPwrgpXQ C\&printsec $=$ frontcover.

Yokoyama, M., 2013. The incomplete guide to the wildlife of Saint Martin. Revised and expanded second edition. - Private publication, 128 pp. http://www.lesfruitsde mer.com/wp-content/uploads/2017/03/SXM-wildlife -2nd-edition.pdf.

Young, F.N., 1981. Predaceous water beetles of the genus Neobidessus from South America (Coleoptera: Dytiscidae). - Coleopterists Bulletin 35: 317-340. https:// www.jstor.org/stable/4007905.

Zagatti, P., B. Lalanne-Cassou \& J. le Duchat d'Aubigny, 1995-2006. Catalogue of the Lepidoptera of the French Antilles. - Digital publication available at http:// www7.inra.fr/papillon/indexeng.htm. 